\author{
UNIVERSidAde de São PAUlo \\ Faculdade De Filosofia, Letras e CiênCias Humanas \\ DEPARTAMENTO DE LINGUÍSTICA \\ Programa de Pós-GraduaÇão Em SEmiótica e Linguística Geral
}

Jõ̃o PAULO DA SILVA

\title{
DEMONSTRAÇÕES EM UMA NARRATIVA SINALIZADA EM LIBRAS
}

VERSÃO CORRIGIDA

Dissertação apresentada ao programa de pósgraduação em Semiótica e Linguística Geral do Departamento de Linguística da Faculdade de Filosofia, Letras e Ciências Humanas da Universidade de São Paulo para obtenção do título de Mestre em Linguística

Orientadora: Profa. Dra. Evani de Carvalho Viotti

São Paulo 
A meu Deus e aos meus pais, esses amigos sempre tão presentes. 


\section{Agradecimentos}

Agradeço a Deus, por criar as condições para este trabalho ser realizado, e a todas as pessoas que, de alguma maneira, participaram do percurso da pesquisa, contribuindo para que esta dissertação fosse possível. Nomeadamente, sou grato:

- aos meus pais, Dora e Jorge, por me ajudarem em todos os momentos e por fazerem dos meus sonhos os seus sonhos; à minha querida Gisele - amiga, namorada, companheira por todo o apoio e por ser sempre tão compreensível quando as minhas ausências foram maiores do que as presenças; a meu tio Silvanio Silva, pelo apoio e incentivo; a todos os amigos de fora da academia, pelo suporte emocional de que necessitei para continuar firme até o último momento: por nome, agradeço ao Delson Donato, ao Renato Silvério, ao Bruno Balduíno, ao Denis Carvalho, ao Denilson Carvalho e ao Rondineli Gonçalves, com os quais eu sempre pude contar quando o fardo esteve mais pesado do que eu podia suportar.

- à Profa. Evani Viotti, minha orientadora, pela excelente orientação que recebi: desde os cursos que me indicou a fazer até as conversas que tivemos ao longo do percurso da pesquisa, nas quais o trabalho foi sendo encaminhado e fui aprendendo a olhar para os dados de uma maneira diferente, percebendo detalhes que antes me passavam despercebidos. Agradeço à Evani também pela paciência nos momentos difíceis do percurso e por acreditar em mim mesmo antes de me conhecer, quando cheguei à USP para manifestar o meu interesse na pesquisa.

- ao Prof. Leland McCleary e ao Prof. Tarcísio de Arantes Leite pela participação na minha banca de qualificação, dando contribuições importantes para a conclusão desta dissertação; agradeço ainda ao Prof. Leland McCleary, pela orientação informal que recebi ao longo da pesquisa, nos cursos de que participei e nas várias conversas que tivemos.

- aos amigos que a academia me trouxe, por conferir leveza aos momentos difíceis da pesquisa e por estarem tão abertos a compartilhar as suas pesquisas e conhecer, de perto, a minha. Primeiramente, agradeço aos membros do LLIC (Laboratório de Linguagem, Interação e Cognição): à Thais Bolgueroni, pelo companheirismo sem igual desde o início da minha pesquisa; à Renata Moreira, por ser sempre uma leitora tão atenta dos meus 
textos e por termos sempre conversas tão interessantes sobre línguas de sinais; à Renata e à Thaís, ainda, agradeço pela ajuda durante a conclusão deste trabalho; à Ana Seelander, pela combinação perfeita de bom humor e seriedade nas conversas que tivemos e nos conselhos que dela recebi; à Fernanda Canever, um agradecimento mais que especial, por me mostrar, na prática, que é possível conduzir uma pesquisa séria sem tanta ansiedade e estresse; ao Rafael Veloso, ao Rodrigo Madrid, à Juliana Osorno, à Cacilda Vilela, ao Alexandre Guimarães, à Joana Franco e à Juliana Nasser, pelos momentos que tivemos juntos, que valeram muito a pena; aos demais colegas da pós-graduação do Programa, que, nos congressos de que participei, estiveram presentes às minhas apresentações, acompanhando a minha pesquisa e trazendo contribuições: agradeço à Livia Oushiro, à Aline Rodero, ao Rafael Minussi, à Júlia Fernandez; agradeço ainda ao André Xavier, pela boa amizade, pelas conversas que tivemos sobre língua de sinais e sobre linguística, e pela leitura atenta de meus textos.

- aos professores da graduação em Letras do Centro Universitário Fundação Santo André: ao Prof. Paulo Chagas, por me introduzir à Linguística; foi em suas aulas que, quando ainda estava começando a aprender a libras no início da graduação, me senti desafiado a entrar pelo caminho dos estudos linguísticos; estendo o meu agradecimento aos demais professores da graduação, que contribuíram para a minha formação, em especial ao Prof. José Marinho do Nascimento, que sempre foi um grande incentivador de que eu ingressasse na pesquisa de pós-graduação, indicando caminhos e se mostrando sempre tão acessível.

- ao Prof. Paulo Chagas e à Profa. Esmeralda Negrão, por participarem da banca de admissão à pós-graduação; agradeço, ainda, à Profa. Esmeralda pelas conversas informais que tivemos sobre a minha pesquisa, nas quais demonstrou sempre tanta atenção: seu interesse em ouvir sobre a minha pesquisa foi sempre muito motivador.

- aos membros da comissão de bolsa.

- à agência $\mathrm{CNPq}$, pelo financiamento da pesquisa.

- ao Departamento de Linguística e ao Programa de Pós-Graduação em Semiótica e Linguística Geral da USP, pela estrutura e pelo apoio.

- aos funcionários do Departamento de Linguística, Robson Vieira e Érica Flávia de Lima, pelo apoio e paciência tantas vezes que precisei. 
- aos professores da graduação e da pós-graduação em Linguística da USP, minha segunda casa, a cujas aulas tive oportunidade de assistir no curso de Elementos e/ou em cursos de pós-graduação; no curso de Elementos: à Profa. Evani Viotti, à Profa. Norma Discini, ao Prof. Jairo Nunes, à Profa. Elaine Grolla e, em especial, ao Prof. Marcos Lopes e ao Prof. Ronald Beline, que me supervisionaram durante o estágio do PAE; nos cursos de pós-graduação: à Profa. Evani Viotti, ao Prof. Leland McCleary e à Profa. Cristina Altman; agradeço ainda ao Prof. Ailton Amélio da Silva, do Instituto de Psicologia, pela oportunidade de cursar uma de suas disciplinas como ouvinte.

- aos professores visitantes, com os quais pude conversar e partilhar os dados durante a minha pesquisa e dos quais obtive valiosas contribuições para o andamento da pesquisa: ao Prof. Scott Liddell, ao Prof. David Quinto-Pozos, ao Prof. Sherman Wilcox e à Profa. Irene Mittelberg.

- à Escola do Futuro, por disponibilizar um espaço para as reuniões de grupo e para o trabalho de pesquisa; agradeço ainda à Cláudia Martins Pires, pela atenção e ajuda sempre que precisamos.

- à C\&A Arte \& Silêncio, por contribuir, a partir da divulgação de seus vídeos, para o conhecimento a respeito da libras e ao Rimar Segala, por autorizar o uso de alguns vídeos nesta pesquisa e por permitir o uso de sua imagem na dissertação.

- à Sylvia Lia, dedico um agradecimento especial por me receber na comunidade surda de uma forma tão acolhedora; à Sylvia devo muito mais do que caberia agradecer neste parágrafo: pelas aulas de libras, por sua amizade gostosa, por me incentivar sempre a ver a vida de uma maneira positiva, pelas longas conversas e por acreditar tanto em mim. Por intermédio dela, conheci outras pessoas queridas, às quais dedico sinceros agradecimentos: agradeço aos professores do curso de especialização em Tradução e Interpretação em libras/português da Faculdade da Santa Casa, especialmente à Miriam Caxilé, ao Vinícius Nascimento e à Juliana Fernandes, em cujas aulas amadureci ideias para o meu projeto; à equipe de intérpretes do Colégio Rio Branco e, especialmente, à Sabine Antonialli Vergamini, diretora de unidade em Granja Vianna, por todo o seu apoio e por, várias vezes, me chamar à sua sala, para vibrar com minhas conquistas, para me dar uns puxões de orelha ou simplesmente para me ouvir. 


\section{Resumo}

O objetivo desta dissertação é apresentar um estudo sobre o emprego de demonstrações em uma narrativa contada em língua de sinais brasileira (libras). Este trabalho parte da ideia de que a copresença de participantes na interação tem influência na maneira como a narrativa é expressa e interpretada (McCleary 2011; McCleary \& Viotti 2014). A investigação dos elementos envolvidos na elaboração das demonstrações é feita a partir de uma perspectiva multimodal.

Para tratar da multimodalidade em interações presenciais, tomei como base as propostas de Clark (1996) e Hutchins (2010), segundo as quais os participantes de uma interação precisam se coordenar para a realização de atividades conjuntas. Nessa perspectiva, demonstrar envolve crucialmente dois aspectos: i) a habilidade de se coordenar na imaginação conjunta dos elementos da narrativa, como os cenários, as personagens e suas ações, os eventos etc; e ii) o uso do corpo, de gestos de diferentes tipos e do espaço como ferramentas nesse ato imaginativo situado na interação.

Para estudar demonstrações especificamente em discursos sinalizados, tomei como base Liddell (2003) e Dudis (2007), que analisaram demonstrações em discursos em língua de sinais americana (ASL), e McCleary \& Viotti (2010, 2011, 2014), que analisaram narrativas em libras. A partir da aproximação entre os trabalhos desses autores, foi possível observar: i) as ocorrências de demonstrações em diferentes níveis discursivos; e ii) a relevância de considerar o nível do narrador nas análises de ocorrências de demonstração.

A narrativa analisada, intitulada "Bolinha de Ping Pong", foi transcrita no software ELAN seguindo o modelo de transcrição proposto por McCleary, Viotti \& Leite (2010). A análise trouxe evidências de que a demonstração é uma estratégia discursiva central em narrativas sinalizadas, e que contar histórias fluentemente envolve, em grande medida, a habilidade no uso de demonstração, integrada com outras estratégias narrativas.

Palavras-chave: libras, narrativa presencial, demonstração, integração conceitual. 


\begin{abstract}
This thesis aims at presenting a study of uses of demonstration in a narrative in Brazilian Sign Language (Libras). The study is based on the idea that the co-presence of the participants involved in any interaction influences the way in which the narrative is expressed and interpreted (McCleary 2011; McCleary \& Viotti 2014). The analysis of the elements involved in the use of demonstrations along the narrative is based on a multimodal approach.

In order to describe the multimodality in face-to-face interaction, I have used models put forward by Clark (1996) and Hutchins (2010). These authors suggest that participants in any interaction coordinate themselves to perform joint activities. According to that approach, demonstration crucially involves two aspects: i) the ability to coordinate the joint imagination of elements of the narrative such as scenarios, characters, actions, events, etc; and ii) the use of the body, different kinds of gesture and the space as tools during that construct the imaginative act in the interaction.

For the study of demonstrations in signed discourses, specifically, I based my analyses on Liddell (2003) and Dudis (2007), who described the use of demonstration in discourses in American Sign Language, and on McCleary \& Viotti (2010, 2011, 2014), who analyzed narratives in Libras. Based on these authors, it was possible to observe: i) the uses of demonstrations are different levels of narrative discourse; ii) the relevance of taking into account the narrator level to the analysis of uses of demonstration.

The analyzed narrative entitled "Ping Pong ball" was transcribed using the software ELAN, following the model proposed in McCleary, Viotti \& Leite (2010). The analysis implies that demonstration is a central discursive strategy in signed narratives, and that, to a great extent, fluency in signing stories involves the ability to use demonstrations, integrated with other narrative strategies.
\end{abstract}

Keywords: libras, face-to-face narrative, demonstration, conceptual integration. 


\section{Sumário}

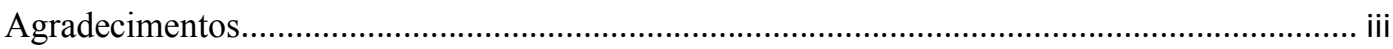

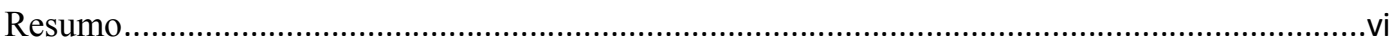

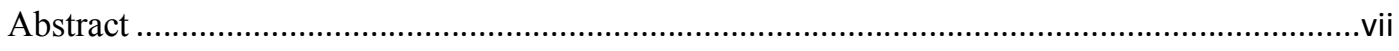

Lista de ilustrações ......................................................................................................

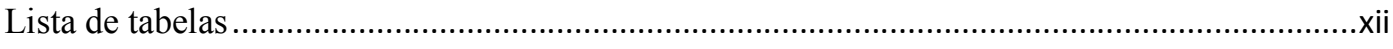

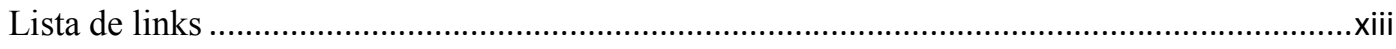

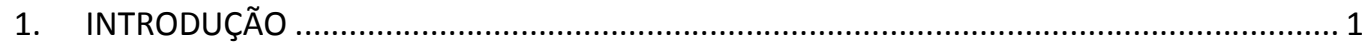

2. EM BUSCA DE UMA ABORDAGEM DESCRITIVA PARA NARRATIVAS MULTIMODAIS EM

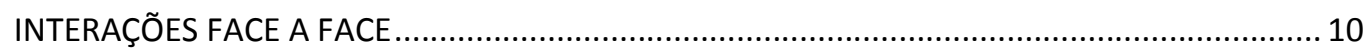

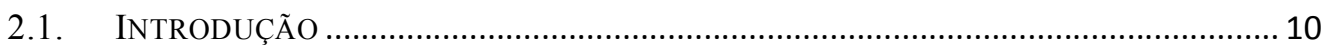

2.2. MULTIMODALIDAdE NA INTERAÇÃO FACE A FACE …........................................ 12

2.3. POR UMA ABORDAGEM DA MULTIMODALIDADE ................................................... 15

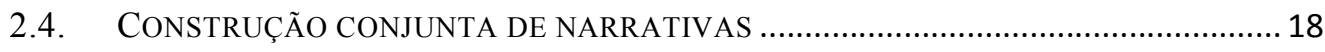

2.4.1. DOMÍNIOS DE AÇÃO EM UMA NARRATIVA PRESENCIAL............................................... 20

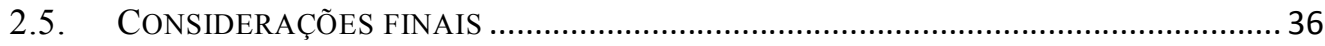

3. METODOLOGIA PARA O ESTUDO DE NARRATIVAS SINALIZADAS NUMA PERSPECTIVA

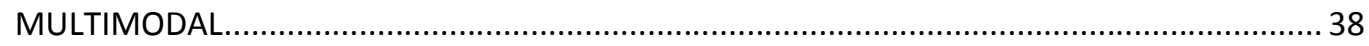

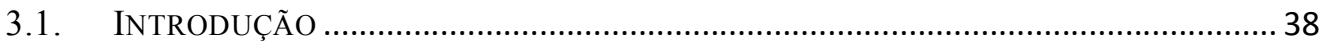

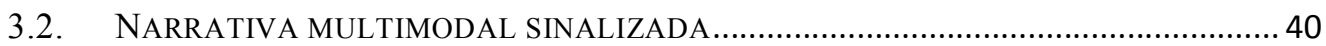

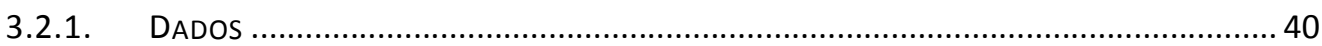

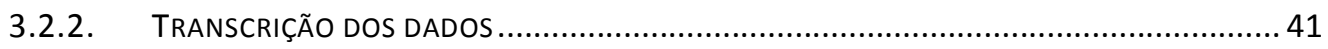

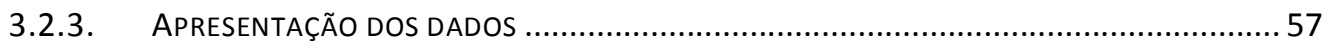

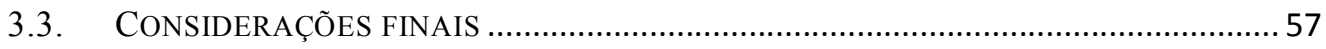

4. DEMONSTRAÇÕES NA NARRATIVA “BOLINHA DE PING PONG” ................................... 59

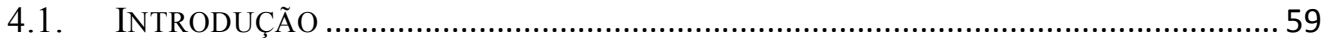

4.2. AnÁlise Da narRativa 'Bolinha de Ping Pong' ........................................... 62

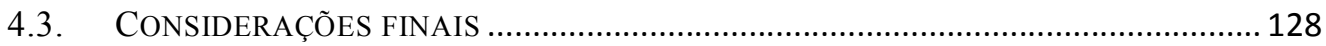

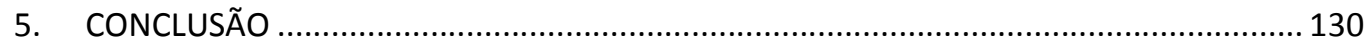

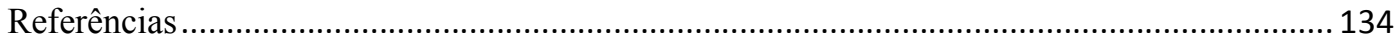




\section{Lista de ilustrações}

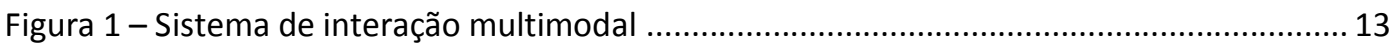

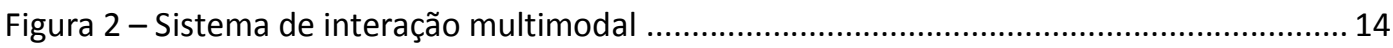

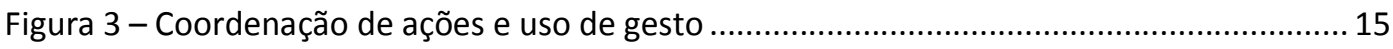

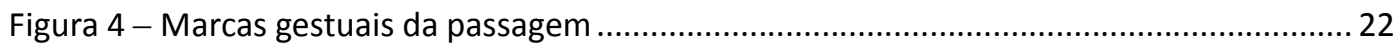

Figura 5 - Níveis de integração conceitual em uma narrativa sinalizada ................................... 23

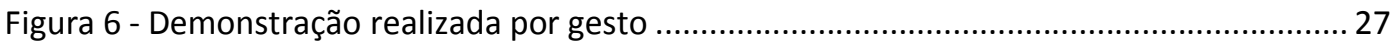

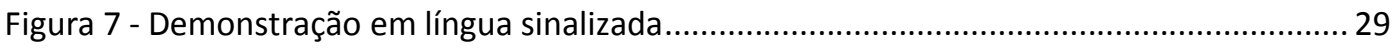

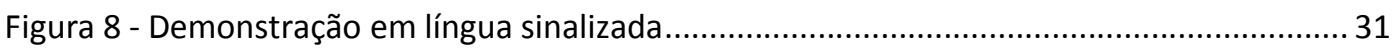

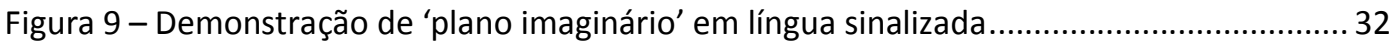

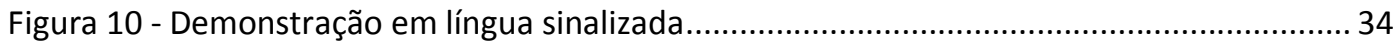

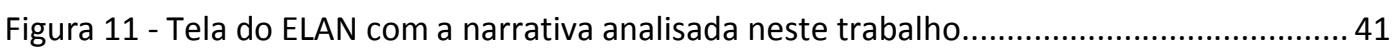

Figura 12 - Trilha de divisão da narrativa em unidades entoacionais........................................ 45

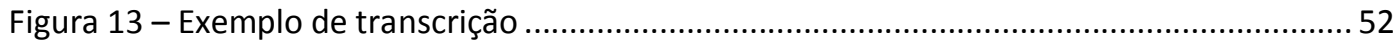

Figura 14 - Anotações nas trilhas de descrição de gestos/sinais manuais.................................... 54

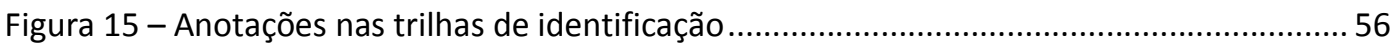

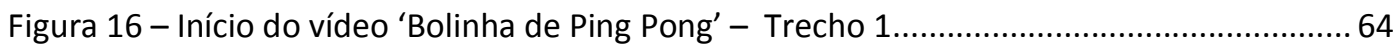

Figura 17 - Expressão facial e movimento manual tensionados simultâneos ao sinal

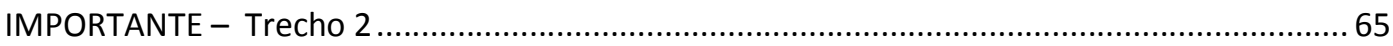

Figura 18 - Expressão facial não tensionada, simultânea à pergunta "Como é o título?" - Trecho

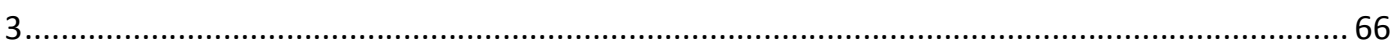

Figura 19 - Expressão facial não tensionada, simultânea à realização do sinal PORTUGUÊS -

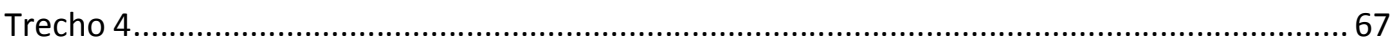

Figura 20 - Expressão facial não tensionada, simultânea à soletração do título em português -

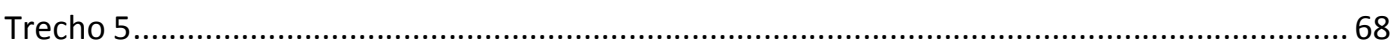

Figura 21 - Apresentação do título da narrativa em libras - Trecho 6.....................................69

Figura 22 - Expressão facial não tensionada, simultânea ao momento em que o sinalizador volta

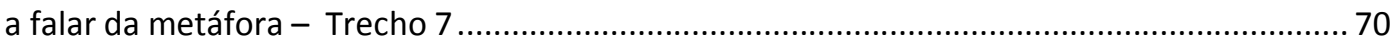

Figura 23 - Demonstração de seriedade/perplexidade e preparação para o início da narrativa -

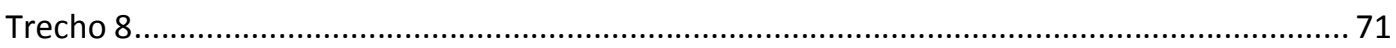

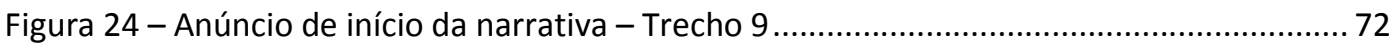

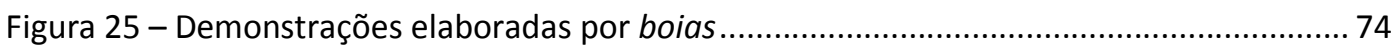

Figura 26 - Expressão facial sério no início da narrativa - Trecho 10 ….................................... 76

Figura 27 - Localização da | arquibancada | no |cenário| da história - Trecho 11 ..................... 77

Figura 28 - Salão de jogo de pingue pongue, visto de cima ..................................................... 78

Figura 29 - Diferentes posições de visualização da mesma cena................................................. 79

Figura 30 - Localização da |mesa | no |cenário| da história - Trecho 12 ................................... 79

Figura 31 - Pessoas na |arquibancada| de formato arredondado - Trecho 13......................... 80

Figura 32 - Localização do |juiz| ao centro do |cenário|-Trecho 14 ........................................ 81 
Figura 33 - Localização dos |jogadores| à cabeceira da |mesa|-Trecho 15

Figura 34 - Demonstração de tensão envolvida nas preliminares do jogo - Trecho 16 ........... 85

Figura 35 - Esquema da organização espacial da narrativa ................................................... 87

Figura 36 - Demonstração de postura corporal e expressões do |jogador| da direita - Trecho

17.

Figura 37 - Posição de visualização do |jogador| da direita, interna ao cenário...................... 89

Figura 38 - Demonstração pictórica de características do |jogador| da direita - Trecho 18 ... 91

Figura 39 - Demonstração de postura corporal e expressões do |jogador| da esquerda - Trecho

19

Figura 40 - Demonstração/descrição de características do |jogador delicado| - Trecho 19....93

Figura 41 - Posição de visualização do |jogador| da esquerda, interna ao cenário..... 95

Figura 42 - Demonstração de postura corporal e caracterização do |jogador barbudo| - Trecho

20.

Figura 43 - Demonstração do |juiz| cumprimentando os |jogadores| Trecho 21 ..................96

Figura 44 - Posição de visualização do |juiz|, interna ao |cenário| de escala real ..................97

Figura 45 - Demonstração da ação de pegar um |objeto arredondado| - Trecho 22 ............. 98

Figura 46 - Posição de visualização do |narrador|, interna ao |cenário| de escala de dimensão real

Figura 47 - Apresentação da personagem |bolinha/nariz de palhaço| Figura 23. 100

Figura 48 - Posição de visualização da |bolinha|, interna ao |cenário| de escala de dimensão real, olhando para o |juiz| 101

Figura 49 - Posição de visualização do |juiz|, interna ao |cenário| de escala de dimensão real, olhando para a |bolinha| na sua mão 102

Figura 50 - Demonstração da fala do |juiz|- Trecho 24 ...... 102

Figura 51 - Demonstração da fala da |bolinha| - Trecho 25 ................................................. 103

Figura 52 - Demonstração da fala do |jogador barbudo| - Trecho 26................................... 104

Figura 53 - Conclusão do |narrador| sobre com quem a |bolinha| vai para começar o jogo -

Trecho 27

Figura 54 - Demonstração do |juiz| ordenando o início do jogo e do |jogador barbudo| lançando a |bolinha| - Trecho 28 106

Figura 55 - O |jogador delicado| segura a |bolinha| na mão - Trecho 29............................ 107

Figura 56 - Demonstração das |personagem| da história olhando para o |jogador delicado| atônitas - Trecho 30 ................................................................................................ 108

Figura 57 - Demonstração do |juiz| ordenando o reinício da partida - Trecho 31 .............. 110

Figura 58 - Demonstração do |jogador delicado| lançando a | bolinha - Trecho 32 ............ 110

Figura 59 - Demonstração da sequência de bates-e-rebates da | bolinha| - Trecho 33 ......... 111

Figura 60 - Demonstrações de movimentos da |bolinha| no |cenário|(I) - Trecho 34 ......... 113

Figura 61 - Demonstrações de movimentos da |bolinha| no |cenário|(II) - Trecho 35 ..... 114

Figura 62 - Demonstração da ação do |juiz| e da |plateia|, acompanhando o movimento da | bolinha| com o olhar - Trecho 36.

Figura 63 - Posição da |plateia| no |cenário| de escala de dimensão 'real' .......................... 116

Figura 64 - Demonstrações de movimentos da |bolinha| no |cenário|(III) Trecho 37......... 117

Figura 65 - Demonstração da |raquete| batendo na |bolinha| - Trecho 38......................... 118

Figura 66 - Demonstração da ação dos |personagens| em velocidade reduzida, sugerindo uma filmagem em câmera lenta - Trecho 39 
Figura 67 - Demonstração da |bolinha| sendo esbofeteada de um lado para o outro - Trecho 40 120

Figura 68 - Demonstração da |bolinha| olhando para o |juiz|, simultânea à demonstração manual, realizada pela fala do narrador - Trecho 41 121

Figura 69 - Demonstração do |juiz| olhando para a |bolinha|, simultânea à demonstração manual, realizada pela fala do narrador - Trecho 42 . 122

Figura 70 - Demonstração da fala da | bolinha|-Trecho 43. 123

Figura 71 - Demonstração da ação do |juiz| pegando a |bolinha| em movimento Trecho 44 124

Figura 72 - Demonstração do impacto sentido pela |bolinha| e da expresão do |juiz| Trecho 45 .. 125

Figura 73 - Demonstração da ação do |juiz| oferecendo a |bolinha| aos |jogadores| - Trecho 46. 126

Figura 74 - Demonstração do |juiz| segurando a |bolinha| e do |narrador| acenando com a cabeça enquanto olha para a câmera - Trecho 47 


\section{Lista de tabelas}

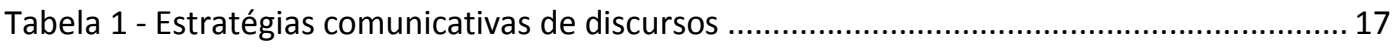

Tabela 2 - Trilhas utilizadas do sistema de transcrição proposto por McCleary, Viotti \& Leite

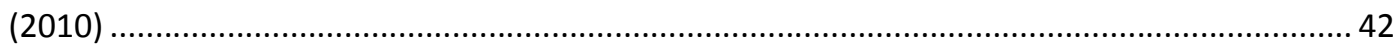

Tabela 3 - Novas trilhas para o registro dos movimentos das mãos, revisto por McCleary (2013)

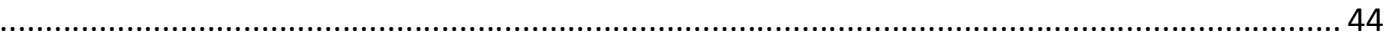

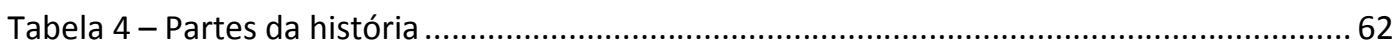




\section{Lista de links}

Trecho 1 - http://www.surprise.Iy/v/?VhGCEznqljo:9:13:0:100

Trecho 2 - http://www.surprise.ly/v/?VhGCEznqljo:13:14:0:100

Trecho 3 - http://www.surprise.ly/v/?VhGCEznqljo:15:16:0:100

Trecho 4 - http://www.surprise.ly/v/?VhGCEznqlio:16:17:0:100

Trecho 5 - http://www.surprise.ly/v/?VhGCEznqljo:18:22:0:100

Trecho 6 - http://www.surprise.Iy/v/?VhGCEznqljo:22:24:0:100

Trecho 7 - http://www.surprise.ly/v/?VhGCEznqlio:24:30:0:100

Trecho 8 - http://www.surprise.ly/v/?VhGCEznqljo:30:31:0:100

Trecho 9 - http://www.surprise.ly/v/?VhGCEznqljo:31:33:0:100

Trecho 10 - http://www.surprise.ly/v/?VhGCEznqljo:33:35:0:100

Trecho 11 - http://www.surprise.ly/v/?VhGCEznqljo:35:37:0:100

Trecho 12 - http://www.surprise.ly/v/?VhGCEznqljo:37:38:0:100

Trecho 13 - http://www.surprise.ly/v/?VhGCEznqljo:39:40:0:100

Trecho 14 - http://www.surprise.ly/v/?VhGCEznqlio:40:42:0:100

Trecho 15 - http://www.surprise.ly/v/?VhGCEznqljo:42:46:0:100

Trecho 16 - http://www.surprise.ly/v/?VhGCEznqljo:46:50:0:100

Trecho 17 - http://www.surprise.ly/v/?VhGCEznqlio:50:53:0:100

Trecho 18 - http://www.surprise.ly/v/?VhGCEznqljo:53:61:0:100

Trecho 19- http://www.surprise.ly/v/?VhGCEznqlio:62:74:0:100

Trecho 20 - http://www.surprise.ly/v/?VhGCEznqljo:74:81:0:100

Trecho 21 - http://www.surprise.ly/v/?VhGCEznqljo:82:84:0:100

Trecho 22 - http://www.surprise.ly/v/?VhGCEznqljo:84:85:0:100

Trecho 23 - http://www.surprise.ly/v/?VhGCEznqljo:85:90:0:100

Trecho 24 - http://www.surprise.ly/v/?VhGCEznqljo:90:93:0:100 
Trecho 25 - http://www.surprise.ly/v/?VhGCEznqljo:93:95:0:100

Trecho 26 - http://www.surprise.ly/v/?VhGCEznqljo:95:97:0:100

Trecho 27 - http://www.surprise.ly/v/?VhGCEznqljo:97:99:0:100

Trecho 28 - http://www.surprise.ly/v/?VhGCEznqljo:100:108:0:100

Trecho 29 - http://www.surprise.ly/v/?VhGCEznqljo:108:111:0:100

Trecho 30 - http://www.surprise.ly/v/?VhGCEznqljo:111:117:0:100

Trecho 31 - http://www.surprise.ly/v/?VhGCEznqljo:117:119:0:100

Trecho 32 - http://www.surprise.ly/v/?VhGCEznqlio:119:124:0:100

Trecho 33 - http://www.surprise.ly/v/?VhGCEznqljo:124:136:0:100

Trecho 34 - http://www.surprise.ly/v/?VhGCEznqljo:136:140:0:100

Trecho 35 - http://www.surprise.ly/v/?VhGCEznqljo:140:142:0:100

Trecho 36 - http://www.surprise.ly/v/?VhGCEznqljo:142:148:0:100

Trecho 37 - http://www.surprise.ly/v/?VhGCEznqlio:148:150:0:100

Trecho 38 - http://www.surprise.ly/v/?VhGCEznqljo:156:160:0:100

Trecho 39 - http://www.surprise.ly/v/?VhGCEznqljo:160:169:0:100

Trecho 40 - http://www.surprise.ly/v/?VhGCEznqljo:169:174:0:100

Trecho 41 - http://www.surprise.ly/v/?VhGCEznqljo:174:177:0:100

Trecho 42 - http://www.surprise.ly/v/?VhGCEznqljo:177:181:0:100

Trecho 43 - http://www.surprise.ly/v/?VhGCEznqljo:181:186:0:100

Trecho 44 - http://www.surprise.ly/v/?VhGCEznqljo:186:194:0:100

Trecho 45 - http://www.surprise.ly/v/?VhGCEznqljo:195:200:0:100

Trecho 46 - http://www.surprise.ly/v/?VhGCEznqljo:200:205:0:100

Trecho 47 - http://www.surprise.ly/v/?VhGCEznqljo:205:208:0:100 


\section{INTRODUÇÃO}

A narração e a conversação são os gêneros orais mais fundamentais para qualquer sociedade humana. Não há nenhuma sociedade em que as pessoas não usem a língua para conversar e para contar histórias: seja nas interações linguísticas mais corriqueiras ou naquelas que fazem parte de grandes empreendimentos, nós estamos sempre conversando uns com os outros e, durante as conversas, quase inevitavelmente, contamos histórias. Essas histórias, por sua vez, envolvem também outras narrações feitas por personagens e conversas entre as personagens da história. A narração e a conversação são, portanto, gêneros orais relacionados: na maioria das vezes, as conversas envolvem narração e as narrações envolvem conversações (McCleary, 2011).

Apesar de a conversa e a narrativa serem gêneros orais tão fundamentais, o interesse da linguística pelo estudo da língua em uso em situações reais de interação face a face é muito recente. Especificamente no caso das narrativas, a preocupação com o estudo de narrativas escritas é tradicionalmente predominante, de modo que, pouca atenção é dada à situação de interação em que a narrativa se insere e ao impacto que o contexto enunciativo pode ter em sua produção. No estudo de narrativas escritas, a tendência é tratar o texto como um elemento separado da situação enunciativa em que foi

produzido, tomando o texto em si mesmo, enquanto produto acabado, como o material de análise. Nesse caso, o fato de haver um autor de carne-e-osso por trás da produção daquela história é, na maioria dos estudos, praticamente indiferente: o que importa mesmo é o mundo da narração e da narrativa, do qual esse autor de carne-e-osso não participa (McCleary \& Viotti, 2014). 
No caso das histórias contadas presencialmente, o autor de carne-e-osso não pode ser ignorado: sua presença certamente tem um papel importante na construção da significação desses discursos. Em alguns trabalhos, sobretudo naqueles relacionados a uma área de estudos relativamente recente, conhecida como 'estudos do gesto', alguns autores, detendo-se em diferentes aspectos de narrativas orais contadas em interação face a face, têm se preocupado em descrever o impacto causado pela presença do corpo do enunciador na maneira como a narrativa é expressa e interpretada. No caso das narrativas em línguas de sinais - objeto de estudo desta dissertação -, essa questão é ainda mais relevante, pois, como observam McCleary \& Viotti (2014), o corpo dos interlocutores, o espaço de enunciação e ação dos corpos não são elementos incidentais no processo narrativo: a organização da narrativa depende da organização do espaço de enunciação e a construção da narrativa envolve a atuação de corpos nesse espaço conceitualmente organizado.

O objetivo deste trabalho é analisar um dos aspectos da produção de narrativas contadas presencialmente, que é o uso de demonstrações em uma narrativa em língua de sinais brasileira (libras). Para isso, tomo como base trabalhos que, estudando língua em uso em uma perspectiva multimodal, reconhecem a parceria entre língua e gesto na construção da significação em interação face a face (McNeill, 1992; Clark, 1996; Liddell, 2003; Dudis, 2007, 2011; Hutchins, 2010; McCleary \& Viotti, 2010, 2011, 2014; dentre outros). Duma perspectiva que leva em consideração a copresença de corpos em interação, o uso da língua em situações presenciais é apenas uma parte de um todo de multimodalidade que constitui o dinamismo das situações e da vida (Hutchins, 2010). Nessas situações, as pessoas atuam conjuntamente, criando várias camadas de significação nos seus discursos.

De acordo com seus propósitos comunicativos, com a disponibilidade do canal receptivo (i.e. se as pessoas podem ver e/ou ouvir umas às outras durante a comunicação) e com o esforço empregado para se comunicar de certa maneira, as pessoas optam por usar diferentes recursos - verbais e não verbais - na comunicação (Clark, 1996: 186). Em uma situação de uso de língua oral, se as pessoas puderem ver uma às outras, é comum que elas usem gestos não vocais de vários tipos, produzidos por diferentes partes do corpo, enquanto estão falando. Nesse sentido, este trabalho parte da ideia de Clark \& Gerrig (1990) e Clark (1996) sobre situações de interação face a face em língua oral, de que é comum que as pessoas façam uso de três estratégias cognitivas diferentes para a 
elaboração de seus discursos: a descrição, a indicação e a demonstração. ${ }^{1}$ Para Clark, as pessoas podem, por exemplo, fazer uma descrição de algo como um peixe, usando a palavra peixe; podem fazer a indicação de um determinado peixe apontando para ele; ou podem fazer a demonstração do tamanho do peixe mantendo as mãos, palma a palma, afastadas uma da outra em frente ao peito (1996: 391). ${ }^{2}$

De acordo com os três aspectos mencionados - propósitos comunicativos, disponibilidade receptiva e esforço -, as demonstrações, as descrições e as indicações são integradas na elaboração dos discursos presencialmente elaborados, e, juntos, constituem elementos que compõem, no uso da língua, um todo comunicativo. As demonstrações usadas durante as histórias vêm acompanhadas das descrições (entendidas, grosso modo, como o uso de itens linguísticos convencionais) e de indicações (o uso de índices de vários tipos: apontamentos manuais, direcionamento do olhar, posicionamento do corpo, dentre outros).

A demonstração é, pois, ao lado da descrição e da indicação, uma estratégia cognitiva e discursiva que consiste em usar elementos do espaço de enunciação (o corpo do sinalizador, o espaço em volta dele, objetos físicos presentes no espaço de enunciação ou, até mesmo, elementos mais abstratos, como a progressão temporal, dentre outros) para apresentar iconicamente aspectos sensorialmente perceptiveis (em geral, visuais e sonoros) de um referente (entidades, estados, processos ou ações). ${ }^{3}$ As demonstrações diferem tanto das descrições quanto das indicações pelo fato de que criam dinamicamente representações visuais e/ou sonoras icônicas dos referentes, de modo que os interlocutores

\footnotetext{
${ }^{1}$ Num quadro mais geral, a proposta de Clark (1996) é a de que o uso da língua é um tipo de ação conjunta, em que as pessoas coordenam suas ações para que a atividade em questão possa ser realizada (como se coordenariam para dançar uma valsa ou para tocar um dueto). Nessa perspectiva, é importante tratar língua em uso levando em consideração a situação comunicativa em que uma dada interação está acontecendo e as condições de produção de discurso no contexto em que a interação acontece (e.g., se o meio de produção e recepção da língua é escrito, falado ou sinalizado; se as pessoas podem ver e/ou ouvir bem umas às outras durante a comunicação; se elas estão sendo gravadas/filmadas, qual é número de participantes envolvidos e o grau de intimidade entre eles, dentre outras).

${ }^{2}$ Como Clark está considerando o uso de línguas orais, o que se pode depreender de sua definição de descrição é que tudo o que for expresso por meio de língua entra nessa categoria, mesmo que não se trate de uma atividade linguística propriamente descritiva.

${ }^{3}$ A conceitualização que o falante/sinalizador faz do espaço de enunciação é bastante ampla e envolve todo o conhecimento que ele tem da situação corrente. Os elementos mais concretos dessa conceitualização são aqueles que são experienciados diretamente a partir do corpo (p.ex. a percepção de objetos no ambiente, sua localização no espaço etc); os elementos mais abstratos, por sua vez, são aqueles que são entendidos metaforicamente, por intermédio da percepção de outros elementos, tidos como concretos (e.g. a progressão temporal - a conceitualização de que o tempo passa - tem sua base conceitual na percepção de movimento de entidades e mudança de estados naturais, como, por exemplo, o movimento do sol no céu).
} 
são capazes de perceber os aspectos representados pelas demonstrações como se estivessem presenciando o próprio referente. ${ }^{4}$ As demonstrações podem ainda variar de mais concretas a mais abstratas, sendo as primeiras, em geral, mais icônicas do que as últimas.

Nas narrativas contadas face a face, um exemplo prototípico de demonstração é aquele em que o narrador usa o seu corpo, o espaço em torno dele e, em alguns casos, a sua fala, seja ela oral ou sinalizada, para apresentar ações de personagens de uma história que está contando. ${ }^{5}$ Nesse processo, o narrador conceitualiza a si mesmo como sendo a personagem da história e age, por meio de pantomimas, como se fosse aquela personagem. Seja em língua oral ou sinalizada, esse tipo de demonstração envolve o uso de expressões faciais para caracterizar as personagens e imitação de ações e de posturas corporais das personagens; além desses recursos, os falantes ainda usam modulações de voz e os sinalizadores, modulações em sinais, para demonstrar diversos aspectos icônicos em relação à história que estão contando. ${ }^{6}$

Além desse tipo de demonstração, outro tipo bastante frequente é aquele em que os falantes usam sinais/gestos manuais icônicos para representar visualmente algumas características perceptíveis dos referentes que fazem parte da narração (como no exemplo acima, em que o gesto manual é usado para demonstrar o tamanho do peixe). Nesses casos, a configuração de mão, sua localização, seus movimentos e a orientação das palmas usados nos sinais/gestos manuais são icônicos em relação às características das entidades, ações, estados ou processos que se pretende representar. Em todas as demonstrações, esses sinais/gestos manuais são usados para apresentar iconicamente algumas características visualmente perceptíveis de alguns desses referentes, relevantes num

\footnotetext{
${ }^{4}$ Essa distinção não significa que essas estratégias funcionem separadamente; pelo contrário, no uso da língua em interações face a face, as indicações, as descrições e as demonstrações são integradas, formando um todo comunicativo. Em um discurso em língua oral ou sinalizada, as demonstrações dependem tanto do emprego de índices quanto de descrições para que a sua elaboração e interpretação adequadas sejam alcançadas.

${ }^{5}$ A demonstração da fala de uma personagem é o que, em estudos da narrativa, se chama 'discurso direto'.

${ }^{6}$ Como tradicionalmente houve um grande interesse no estudo dos elementos verbais da comunicação humana, os elementos não verbais foram colocados em uma posição secundária em relação ao estudo de elementos verbais, dando a impressão de que os elementos não verbais são, de fato, periféricos no uso da língua. Os estudos de língua em situação concreta de uso mais recentes, beneficiados pelas tecnologias de registro de dados audiovisuais cada vez mais avançados, vêm mostrando que os elementos não verbais não são tão periféricos como os estudos tradicionais quiseram fazer crer; antes, observa-se que recursos semióticos de diversas naturezas são abundantes nos discursos e contribuem fundamentalmente para a construção dos significados.
} 
determinado momento do discurso; eles criam um tipo de experiência visual daquilo que é representado (Clark \& Gerrig 1990: 767). Por isso, Murphy considera esse tipo de experiência como de percepção em modo hipotético, isto é, a possibilidade de ver os gestos usados na demonstração como se eles fossem as coisas imaginadas (2004: 269).

Esse tratamento dado aos sinais/gestos usados para realizar demonstração nos discursos presenciais é diametralmente oposto àquele dado pela literatura tradicional das línguas de sinais que, buscando fortalecer o estatuto linguístico dessas línguas, ignorou a presença da gestualidade nos discursos sinalizados e procurou maneiras de dar um tratamento estritamente linguístico para os dados investigados (McCleary \& Viotti, 2010, 2011). ${ }^{7} \mathrm{Na}$ maioria desses trabalhos, a proposta foi a de que muito daquilo que, neste trabalho, se reconhece como tipos de demonstrações - especialmente aqueles relacionados aos sinais manuais - pudesse ser considerado como itens lexicais morfologicamente construídos por meio de um morfema classificador (Supalla 1986). De acordo com esse tipo de tratamento, boa parte desses sinais envolveria um número grande de morfemas em uma formação morfológica altamente complexa; o morfema classificador seria a configuração de mão icônica.

Schembri (2003), apresentando uma revisão da literatura de classificadores em línguas orais e sinalizadas, argumenta que a comparação entre as configurações de mão nesses sinais (que ele chama verbos policomponenciais) e os classificadores nas línguas orais é problemática. Para ele, as configurações de mão nos verbos policomponenciais em língua sinalizada têm origem, forma e função que parecem ser distintas daquelas que aparecem em classificadores de línguas orais (p. 28). ${ }^{8}$

Buscando uma alternativa para essa abordagem tradicional das línguas de sinais, alguns autores têm observado que essas formas, em línguas de sinais, apresentam bastante

\footnotetext{
${ }^{7}$ Como é bem sabido, William Stokoe foi quem primeiramente mostrou que a língua de sinais americana (ASL), até então considerada um tipo de linguagem pantomímica, apresenta propriedades linguísticas comuns às línguas orais. As evidências apresentadas por Stokoe surpreenderam a comunidade de linguistas, porque mostravam que o senso comum assumido pela própria linguística (de que as línguas de sinais não eram línguas naturais) estava equivocado. Depois de Stokoe, outros linguistas continuaram buscando mais evidências para corroborar o estatuto linguístico dessas línguas. Esse trabalho surtiu o efeito esperado: hoje as línguas de sinais têm o seu estatuto linguístico reconhecido dentre as demais línguas do mundo. Contudo, como aponta Leite (2008: 34), essa busca por características linguísticas nas línguas de sinais não foi livre de excessos.

${ }^{8} \mathrm{Na}$ sua revisão da literatura a respeito dos classificadores em línguas sinalizadas, Schembri mostra que, nem mesmo entre os autores que reconhecem a existência de formas classificadoras em línguas de sinais, há muita concordância sobre a classificação dessas formas, que variam, entre os autores, de duas a sete subclasses, sendo que cada um dos pesquisadores propõe um tipo diferente de análise (p. 09).
} 
similaridade com os gestos manuais que os falantes de línguas orais, não sinalizadores, usam enquanto se comunicam (McNeill, 1992; Cogill, 1999; citados por Schembri). A diferença entre essas formas produzidas por sinalizadores e por não sinalizadores, contudo, parece ser que, enquanto os não sinalizadores tendem a enfatizar a similaridade visual com o referente, as formas produzidas por sinalizadores tendem a obedecer alguns dos padrões de boa formação de sinais lexicais, sendo, de alguma forma, mais abstratas e categóricas que aquelas usadas por não sinalizadores (Singleton et. al., 1993; citados por Schembri, 2003: 26). A sugestão de Kendon (1988) para explicar essa diferença é a de que dois processos operam em língua sinalizada: a representação imagética (imagem representation) e a formação de sinal (sign formation); o primeiro diz respeito à 'representação gestual de alguma imagem concreta', enquanto a segunda corresponde às 'regras de boa formação e restrições de ordem morfofonológicas' (Schembri, 1996: 267). Neste trabalho, seguindo a proposta de Clark (1996), reconheço os processos mencionados por Kendon como sendo associados às estratégias cognitivas e discursivas de demonstração e descrição, respectivamente.

É preciso, contudo, ter em mente que, entendendo que os enunciados produzidos em interação face a face são sempre compostos por elementos semióticos de diversas naturezas, o reconhecimento do que é linguístico ou gestual nos enunciados é sempre nebuloso. Clark (1996), assumindo uma perspectiva multimodal para o estudo de língua oral, argumenta que, uma vez que tanto elementos tradicionalmente reconhecidos como linguísticos quanto os gestuais se integram nos enunciados, essas categorias, vista de uma perspectiva multimodal, precisam ser repensadas. Seguindo a proposta de Clark, a distinção que se faz neste trabalho, mais do que se preocupar em distinguir língua de gesto, enfatiza as diferentes estratégias cognitivas empregadas na elaboração do discurso: descrição, indicação ou demonstração.

Observando os discursos de uma perspectiva multimodal, é possível reconhecer que, tanto nos discursos das línguas orais quanto das línguas sinalizadas, existem muitos tipos de demonstrações e cada um deles difere do outro pelos elementos conceituais que cada demonstração representa. ${ }^{9}$ Dudis $(2007,2011)$, estudando o discurso da língua de

\footnotetext{
${ }^{9}$ Assentado sobre uma teoria de base cognitiva, o entendimento do fenômeno neste trabalho é o de que uma demonstração não representa um referente diretamente, mas a conceitualização que o falante faz desse referente. Certas conceitualizações envolvem elementos conceituais que não estão presentes em outras conceitualizações. Por exemplo, a conceitualização que fazemos de ações, em geral, envolve sempre um elemento temporal, pois sabemos que toda ação se desenrola necessariamente num
} 
sinais americana (ASL), propõe, com base na proposta inicial de Liddell (2003) e fundamentado na teoria de integrações conceituais (Fauconnier \& Turner, 2002), que o processo básico para a elaboração de demonstrações é a integração conceitual entre elementos do espaço do evento descrito (conceitualização da história que está sendo contada) e elementos conceituais do espaço real (o espaço mental que corresponde à conceitualização da situação de enunciação corrente). ${ }^{10}$ Nesse processo, o falante/sinalizador integra os elementos conceituais da história a elementos do espaço real, tornando-os 'presentes' por meio da demonstração. Quando o falante/sinalizador demonstra as ações de uma personagem por pantomimas, é como se o interlocutor estivesse vendo a própria personagem realizando as ações diante de si. ${ }^{11}$

Além disso, pela possibilidade de partição conceitual do corpo do sinalizador e do espaço de sinalização em frente ao corpo, é possível haver múltiplas integrações simultâneas no discurso, de modo que vários referentes diferentes, ou vários aspectos de um mesmo referente, podem ser representados simultaneamente por meio de demonstrações (Liddell, 2003; Dudis, 2007). Para McCleary \& Viotti (2014), é, ainda, pela partição do corpo e pelas múltiplas integrações conceituais que, nas línguas sinalizadas, vozes e perspectivas narrativas podem ser realizadas simultaneamente no discurso narrativo.

A construção de qualquer narrativa (seja ela presencial ou não) depende, fundamentalmente, da criação conjunta do mundo da história por parte dos interlocutores; nessa criação, várias camadas de significação (ou domínios de ação) são construídas e elas são importantes, no caso do discurso presencial, para o entendimento dos significados elaborados por meio de palavras e gestos (Clark, 1996: 388). Como essas camadas de significação são sempre construídas conjuntamente durante as interações, elas se constituem como espaços intersubjetivos. De acordo com McCleary \& Viotti, a elaboração do discurso narrativo envolve a instanciação dos diferentes níveis de

\footnotetext{
determinado período de tempo. A demonstração de características físicas de entidades não envolve, por sua vez, esse tipo de elemento conceitual.

${ }^{10}$ Neste trabalho, seguindo a proposta de Clark \& Gerrig (1990) e Clark (1996), uso o termo demonstração para me referir àquilo que Dudis chama depiction no discurso da ASL.

${ }^{11}$ Como vai ficar claro no capítulo de fundamentação teórica, esta dissertação vai sugerir que se dê uma maior abertura aos estudos de demonstração nos discursos sinalizados. Embora tomando como ponto de partida os estudos realizados por Liddell (2003) e Dudis (2007), a ideia aqui é a de integrar as demonstrações sinalizadas no âmbito dos estudos da interação multimodal, para permitir a distinção de demonstrações feitas em diferentes níveis narrativos, o que não se verifica nos trabalhos de Liddell e Dudis.
} 
intersubjetividade narrativa (que pode ser autor implícito/leitor implícito, narrador/narratário, personagens/personagens) e esses espaços são construídos online pelos interlocutores durante a construção da narrativa presencial.

O estudo de narrativas contadas presencialmente envolve especificidades ainda pouco tratadas pelos estudos de narrativa. Desse modo, o estudo dessa modalidade de narrativas requer que se busque, antes de qualquer coisa, uma abordagem adequada para o seu tratamento. Nesse sentido, inicio esta dissertação buscando uma abordagem descritiva para o estudo de narrativas multimodais contadas presencialmente. Os dois capítulos seguintes desta dissertação tratam dessa questão: no capítulo 2, discuto alguns aspectos teóricos dessa abordagem e, no capítulo 3, discuto alguns aspectos metodológicos do tratamento de narrativas multimodais.

Mais especificamente, no capítulo 2, apresentando algumas diferenças fundamentais entre narrativas escritas e narrativas orais, discuto, a partir da proposta de Hutchins (2010), o estudo do sistema de multimodalidade das interações presenciais. Nessa discussão, observo alguns aspectos sobre como se dá a interação das pessoas entre si e delas com o ambiente em que estão copresentes. Discuto, em seguida, alguns elementos cognitivos e interacionais que participam da construção dos significados nos discursos presenciais e do modo como, segundo a proposta de McCleary \& Viotti (2010, 2011), os participantes se engajam, em língua sinalizada, na construção conjunta do mundo da narração e do narrado. Por fim, apresento exemplos de demonstrações realizadas no nível do narrador e no nível da personagem.

No capítulo 3, a discussão envolve, inicialmente, uma reflexão sobre um recorte metodológico específico para um sistema de comunicação multimodal. Em seguida, faço uma discussão a respeito da obtenção de dados, seu tratamento e a disponibilização de dados linguísticos para análises. A narrativa que é objeto de estudo deste trabalho, intitulada "Bolinha de Ping Pong", foi transcrita segundo o modelo de transcrição proposto por McCleary, Viotti \& Leite (2010) para transcrição de dados sinalizados, modificado por avanços realizados mais recentemente a partir de trabalhos realizados por membros do LLIC (Laboratório 'Linguagem, Interação, Cognição'). ${ }^{12}$ Comento algumas

\footnotetext{
${ }^{12}$ Agradeço a Rimar R. Segala por permitir o uso da narrativa para fins desta pesquisa. A narrativa pode ser acessada a partir do link a seguir: https://www.youtube.com/watch?v=VhGCEznqljo. Último acesso em 09/02/2014.
} 
dificuldades iniciais de transcrição e o modo como as alterações no modelo de transcrição resolveram problemas específicos relacionados à perspectiva multimodal deste trabalho.

No capítulo 4, apresento uma análise das ocorrências de demonstração na narrativa 'Bolinha de Ping Pong'. A discussão desse capítulo é norteada pela seguinte questão: como é possível saber a que nível de intersubjetividade narrativa (nível do sinalizador de carne-e-osso, do narrador ou da personagem) uma determinada demonstração pertence na elaboração de uma narrativa sinalizada? A partir desta pergunta, faço uma descrição das ocorrências de demonstrações ao longo da narrativa e dos elementos que estão envolvidos nessas demonstrações; nessa análise, mostro como as demonstrações, simultâneas e sucessivas, ora se intercalando ora convergindo, se organizam na construção e estruturação da narrativa.

No capítulo 5, concluo a dissertação retomando o percurso percorrido na dissertação e fazendo considerações gerais sobre o emprego de demonstrações em narrativas sinalizadas. 


\section{EM BUSCA DE UMA ABORDAGEM DESCRITIVA PARA NARRATIVAS MULTIMODAIS EM INTERAÇÕES FACE A FACE}

\subsection{INTRODUÇÃO}

A contação de histórias em situação de interação face a face é um dos tipos de atividade linguística mais comuns que realizamos. Desde enunciados simples, usados na descrição de eventos cotidianos triviais (e.g. eu vi você ontem), até histórias extensas e elaboradas, que requerem um turno de fala mais estendido, narrativas estão em praticamente todas as nossas interações comunicativas. É por meio de narrativas entendidas neste trabalho como uma ferramenta cognitiva para a organização da experiência (Turner, 1996) - que elaboramos discursivamente, seja em interações feitas por meio da escrita ou face a face, mundos tidos como reais ou imaginários: descrevemos situações, introduzimos personagens, ordenamos temporalmente e descrevemos os eventos dos quais as personagens participam. Apesar de as histórias contadas em interações face a face (seja em línguas orais ou sinalizadas) serem tão frequentes e fundamentais na vida cotidiana, elas têm encontrado pouco espaço nos estudos linguísticos, sendo o estudo de narrativas escritas muito mais frequente tanto na linguística quanto na narratologia e em outras áreas que tomam narrativas como seu objeto de estudo (McCleary \& Viotti, 2014). Existem, contudo, diferenças entre as narrativas escritas e as narrativas contadas em interações face a face e, por isso, o estudo de narrativas faladas/sinalizadas presencialmente requer, antes de qualquer coisa, que se busque uma abordagem adequada para o seu tratamento.

Como explicitado em McCleary \& Viotti, uma das principais diferenças entre narrativas elaboradas em interação face a face e narrativas escritas está justamente no fato de que os participantes da interação comunicativa estão em situação de copresença na contação de história face a face, mas distanciados espacial e temporalmente quando se trata de narrativas escritas. Em narrativas escritas, o autor de carne-e-osso e o leitor de carne-e-osso não veem um ao outro; mediados pelo texto escrito, autor de carne-e- 
osso e leitor de carne-e-osso criam, respectivamente, um leitor e um autor imaginários (ou, nos termos da narratologia, criam um leitor e um autor implícitos). Nesse caso, de acordo com McCleary \& Viotti, é possível pensar, então, em um desdobramento da situação de enunciação em dois momentos: um primeiro momento em que o texto é escrito e um segundo momento em que o texto é lido. Nessa situação comunicativa, nem as subjetividades do mundo real (a do autor de carne-e-osso e a do leitor de carne-e-osso), nem a situação física e corporal em que cada um desses sujeitos está no momento da escrita e da leitura costumam ser relevantes para o estudo da narrativa; somente as situações e as subjetividades internas à narrativa, isto é, aquelas que são construídas a partir da narrativa como um todo - a intersubjetividade do autor/leitor implícitos - e aquelas que são marcadas no texto - as intersubjetividades do narrador/narratário e da(s) personagem(s)/personagem(s) é que constituem objetos dos estudos narratológicos (McCleary \& Viotti, 2014).

No estudo de narrativas escritas, um recorte bastante específico é imposto pela própria tecnologia de registro; na escrita de uma história, o autor de carne-e-osso cria um narrador, que aparece no texto como uma 'voz fantasma', descorporeada, que usa palavras para elaborar o mundo virtual da narrativa (McCleary, 2011: 102). Como o único objeto acessível ao leitor de carne-e-osso é o texto, o autor de carne-e-osso tem, como recurso de criação preponderante, enunciados linguísticos, usados pelo narrador para descrever os cenários, apresentar as personagens, narrar o desencadear dos eventos, e assim por diante.

Nas contações de história face a face, contudo, a copresença do autor de carne-eosso e do seu interlocutor de carne-e-osso tem importância na contação e na interpretação da história (McCleary, 2011). Diferente das narrativas escritas, em que a interação é mediada pelo texto escrito, nas interações face a face, os interlocutores podem ver um ao outro e ambos podem ver o ambiente em que estão localizados. Numa situação assim, outros elementos, além das palavras, normalmente estão envolvidos na contação da história. Uma vez que os participantes da interação estão copresentes, eles podem observar as modificações corporais um do outro durante a contação da história: o interlocutor pode observar as mudanças na postura corporal do contador da história, em suas expressões faciais e na mudança de voz, bem como a tensão e rapidez nos gestos coocorrentes à fala oral ou à sinalização (no caso de língua sinalizada); essas alterações normalmente são muito significativas na interpretação da história que está sendo contada. 
Da mesma maneira, as expressões do interlocutor e mudanças em sua expressão são monitoradas pelo contador da história e têm influência na contação da história (McCleary, 2011: 99). ${ }^{13}$ A copresença dos interlocutores em um ambiente potencialmente significativo também traz complexidade ao estudo dessa modalidade de narrativas, ainda pouco explorada.

Como costuma ser notado por autores que estudam o uso da língua em situação de interação face a face (Hutchins, 2010; McCleary, Viotti \& Leite, 2010; McCleary, 2011), a observação das interações humanas e da língua em uso de uma perspectiva corporeada é grandemente favorecida pela possibilidade que temos hoje de registrar os discursos por meio de registro visual, por equipamentos cada vez mais acessíveis. Cabe lembrar que, uma vez que a própria tecnologia de registro de dados pode promover uma redução ou ampliação de detalhes disponíveis à observação do analista, o tipo de tecnologia usada (escrita/gravação de áudio/filmagem) no registro de dados tem influência direta nas análises.

O objetivo deste capítulo é discutir alguns aspectos teóricos de uma abordagem descritiva para as narrativas multimodais faladas/sinalizadas, elaboradas em situação de interação face a face. Para isso, inicio discutindo o estudo do sistema de multimodalidade das interações presenciais para, em seguida, tratar de como se dá a interação não só das pessoas entre si, mas também delas com o ambiente em que estão copresentes; de alguns dos elementos cognitivos e interacionais que participam na construção dos significados; e do modo com que os participantes da interação se engajam para a construção do mundo da narração e da narrativa.

\subsection{MUltimodalidade NA INTERAÇÃO FACE A FACE}

Um estudo como o que aqui se propõe, que dá a devida importância à copresença de corpos em interação para o entendimento de narrativas elaboradas face a

\footnotetext{
${ }^{13}$ McCleary \& Viotti (2014) observam que, uma vez que a construção do mundo virtual da história em línguas orais se dá fundamentalmente por meio de língua, mesmo nos estudos de contações de histórias presenciais, pouca atenção costuma ser dada ao papel do corpo na contação de histórias. Nas línguas de sinais, diferentemente, o uso do corpo do sinalizador e do espaço ao seu redor tem um papel fundamental na contação e interpretação da história e, ainda que sua importância tenha sido igualmente minimizada em muitos trabalhos sobre essas línguas, a sua exploração revela que esses elementos são fundamentais na organização do discurso narrativo sinalizado.
} 
face, se insere no âmbito dos estudos da multimodalidade que assumem que o conhecimento emerge da interação das pessoas entre si e delas com o mundo social e material - e que esse processo é situado no ambiente, e não simplesmente interno aos indivíduos. Para esses estudos, o desafio é o de mostrar como as pessoas de carne-e-osso desempenham práticas corporeadas nos ambientes em que estão situadas (Hutchins, 2010: 91). O uso da língua em situações de interação presencial é apenas uma parte de um todo de multimodalidade que constitui o dinamismo das situações e da vida. A Figura 1 a seguir, retirada de Hutchins, ilustra de modo esquemático e simplificado, a complexidade das relações que pode ser depreendida do estudo das interações em situação presencial.

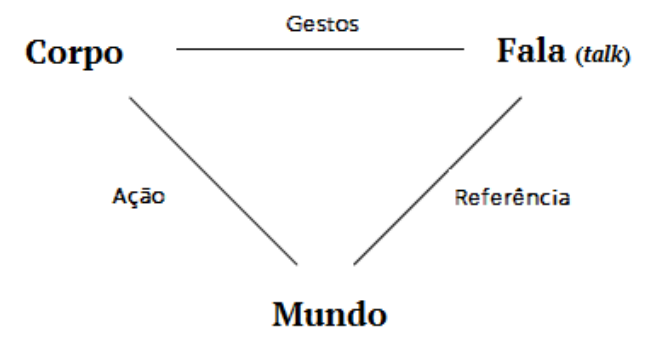

Figura 1 - Sistema de interação multimodal (retirado de Hutchins, 2010)

Como sugere esse esquema, numa situação de uso de língua em interação face a face, há um sistema complexo de ações que são desempenhadas, envolvendo a interação dos participantes da conversa entre si e com o ambiente em que eles estão situados juntos. Nessa interação de corpos entre si e de corpos em atuação com o mundo, há múltiplas relações acontecendo simultaneamente. Na relação entre o corpo e a fala, podemos observar a produção de gestos; na relação entre a fala e o mundo, constrói-se a relação de referência; e, na relação entre o corpo e o mundo, diferentes tipos de ação são realizados. Essas relações normalmente acontecem simultaneamente. Além disso, as pessoas precisam coordenar suas ações com as ações dos outros para que as atividades sejam bem sucedidas, de acordo com os propósitos daquilo que estiver sendo realizado. Cabe lembrar que a própria fala das pessoas é também um tipo de ação, bem como os gestos que elas produzem durante a sua fala; essa coordenação de ações acontece nas diferentes facetas das relações mencionadas acima. Para entender de que modo cada um dos tipos de ação se distingue de outro, é preciso levar em consideração a noção de domínios de ação (Clark, 1996), apresentada no item seguinte, que diz respeito ao entendimento 
conjuntamente construído, pelos participantes de uma interação, do conjunto de ações realizadas durante as interações.

Como o entendimento da situação é sempre resultante de uma ação conjunta em que os participantes da interação se engajam, uma reformulação do esquema anterior se faz necessária: nas interações face a face, não existe, obviamente, um único corpo nem uma única fala, como sugere a Figura 1 acima; são, pelo menos, dois corpos e, normalmente, duas falas, compartilhando um mesmo mundo, como mostra a Figura 2, a seguir, retirada de Hutchins. ${ }^{14}$

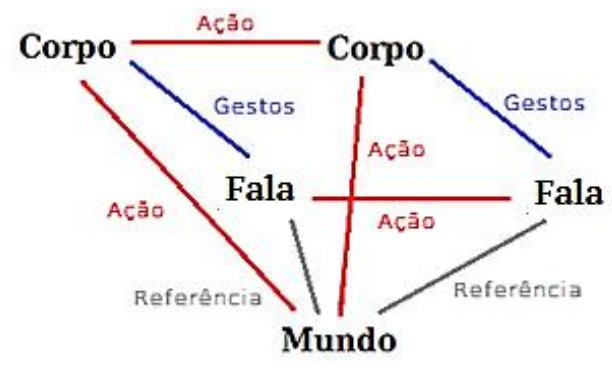

Figura 2 - Sistema de interação multimodal com acréscimo de relações (retirado de Hutchins, 2010)

Nesse esquema, há adição de relações: entre corpo e corpo, entre fala e fala e entre o corpo de um e a fala de outro. Nesse cenário, então, há três facetas de coordenação multimodal que podem ser realizadas: Corpo/Corpo/Mundo, Fala/Fala/Mundo e Corpo/Corpo/Fala/Fala. É nesse cenário de complexidade multimodal que as pessoas coordenam as suas ações nas diversas atividades conjuntas situadas. Na faceta Corpo/Corpo/Mundo, as pessoas coordenam suas ações para fins de cooperação (e.g. uma pessoa passando por outra pessoa na rua sem esbarrar); de colaboração (e.g. pessoas erguendo um objeto pesado juntas); para realizar ações sincronizadas (e.g. como 'decidir' o início e fim de um aplauso); para o estabelecimento e manutenção de atenção conjunta; dentre outros. A faceta Fala/Fala/Mundo, por sua vez, é aquela em que ocorrem os processos de coordenação que dão origem à troca de turno, à contingência sequencial de significado, à referência intersubjetiva e à anáfora

\footnotetext{
${ }^{14}$ A nomeação das relações - ação, gestos, referências - são acréscimos meus à figura, baseados na nomeação das relações feita pelo próprio Hutchins na primeira figura.
} 
(2010: 92). Finalmente, na faceta Corpo/Corpo/Fala/Fala - sobre a qual se atém mais atentamente este trabalho - é que encontramos uma relação muito estreita no uso de elementos verbais e não verbais da comunicação. A relação entre Fala1/Corpo2 pode ser vista em cumprimentos convencionais, em que uma pessoa cumprimenta com um "oi", enquanto a outra pessoa responde com um aceno de cabeça.

\subsection{POR UMA ABORDAGEM DA MULTIMODALIDADE}

Estudar os discursos da perspectiva da multimodalidade exige levar em consideração as pessoas que produzem os discursos e toda a situação em que a comunicação se passa. Como as situações variam bastante, em algumas delas pode ser privilegiado um aspecto da multimodalidade em detrimento de outro, na relação Corpos/Falas/Mundo. Para Hutchins (2010), as interações multimodais mais interessantes são aquelas que reúnem todos os aspectos dessas relações. Nesse sentido, para explorar todas as dimensões da multimodalidade, têm sido focalizados os estudos de interações que acontecem em locais de trabalho, pois, uma vez que as pessoas estão necessariamente engajadas na realização conjunta de alguma atividade, elas utilizam diferentes recursos semióticos durante a comunicação, explorando amplamente a multimodalidade de recursos, como pode ser visto a partir do exemplo apresentado na Figura 3, a seguir.

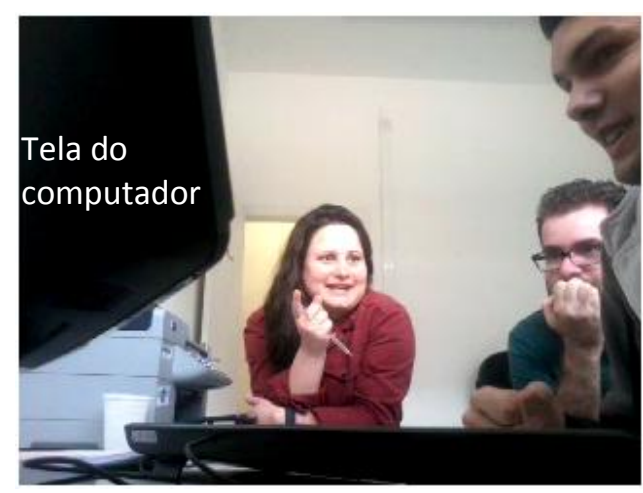

Figura 3 - Coordenação de ações e uso de gesto na interação presencial em local de trabalho

Na situação de trabalho apresentada na Figura 3, que é relativamente simples se comparada a outras situações de locais de trabalho, os participantes da interação estão 
discutindo um texto teórico que está visível para todos na tela do computador do laboratório. ${ }^{15}$ Nessa situação, há uma complexa coordenação de ações que é realizada pelos falantes: enquanto os participantes da conversa discutem o texto, eles olham para a tela do computador, procuram entender o que os outros estão dizendo e, simultaneamente, estão atentos a alterações no tom de voz, aos gestos corporais, às expressões faciais dos outros, etc. Hutchins \& Palen (1997), em estudos em lugares de trabalho, mostram como é relativamente simples perceber, quando se transcreve o que é dito verbalmente nessas situações, o quanto o discurso verbal é insuficiente isoladamente. Uma vez que as pessoas podem ver/ouvir umas às outras e perceber conjuntamente o ambiente em que estão localizadas, os elementos verbais são apenas uma parte, embora igualmente importante, dos recursos utilizados na comunicação presencial. Como pode ser visto na Figura 3, por exemplo, enquanto a falante argumenta a respeito de um aspecto do texto, ela aponta para a tela do computador e olha para um dos participantes da conversa; os outros dois interlocutores, no momento da foto, olham para o texto na tela do computador e acompanham o que é dito sem desviar o olhar do texto. A interação com o objeto físico do ambiente de trabalho - nesse caso, a tela do computador em que o texto está exposto - é relevante para a maneira como as pessoas coordenam a ação na realização da atividade em questão.

Clark (1996), assumindo também uma posição multimodal para o estudo de língua em uso, argumenta que o uso da língua não envolve um único processo (tradicionalmente entendido como sendo a codificação e decodificação de signos linguísticos), mas três processos diferentes: a indicação, a descrição e a demonstração (p. 160). Cada uma dessas estratégias está relacionada a um processo cognitivo diferente e ao emprego de recursos semióticos de diferentes naturezas. A Tabela 1, a seguir, elenca esses processos e os recursos semióticos empregados na sua elaboração.

\footnotetext{
${ }^{15}$ Hutchins \& Palen (1997) estudaram, por exemplo, a complexidade da relação multimodal em uma situação de simulação de voo em um simulador de um Boing 727-200 na NASA; embora a tripulação não estivesse em um Boing real, esse simulador apresenta alta fidelidade. Nessa situação de trabalho, há uma enorme complexidade na interação com o ambiente, uma vez que os pilotos precisam se coordenar na operação de um equipamento altamente complexo, que é o painel de controle de uma aeronave.
} 


\begin{tabular}{ccc}
\hline Estratégia & Processo & Recurso empregado \\
\hline Descrição & Ativação de regras & $\begin{array}{c}\text { Elementos simbólicos } \\
\text { Léxico, regras gramaticais } \\
\text { emblemas, junções }\end{array}$ \\
Indicação & $\begin{array}{c}\text { Localização de } \\
\text { entidades num } \\
\text { domínio conceitual }\end{array}$ & $\begin{array}{c}\text { Realizados por diferentes } \\
\text { partes do corpo }\end{array}$ \\
Demonstração & $\begin{array}{c}\text { Imaginação de } \\
\text { aparências }\end{array}$ & $\begin{array}{c}\text { Ícones } \\
\text { Criados dinamicamente por } \\
\text { diferentes partes do corpo }\end{array}$ \\
\hline
\end{tabular}

Tabela 1 - Estratégias comunicativas de discursos presencialmente elaborados, adaptado de Clark (1996: 184)

Baseado na tricotomia peirceana do signo, Clark propõe que, nas interações linguísticas, as pessoas coordenam suas ações para estabelecer diferentes tipos de associações, dependendo do recurso semiótico empregado. Um signo se relaciona com o objeto a que se refere de três modos diferentes: por associação de regra (símbolo), por conexão física (índice) e por semelhança perceptual (ícone). Dessa maneira, quando as pessoas se envolvem numa interação comunicativa, elas precisam se coordenar no uso das estratégias comunicativas mencionadas na tabela: na descrição, os interlocutores se coordenam na ativação da mesma regra para cada símbolo; na indicação, os interlocutores se coordenam na localização de entidades num domínio conceitual; na demonstração, os interlocutores se coordenam para imaginar a aparência das coisas.

Dito de outro modo, para descrever, as pessoas usam fundamentalmente, palavras ou gestos convencionais (emblemas); para indicar, elas apontam - seja pelo uso de gestos ou de itens linguísticos - para alguma entidade presente no espaço de enunciação ou em outro espaço conceitual, correspondente a outro tempo e espaço físico; finalmente, para demonstrar, elas simplesmente usam o corpo (ou várias partes dele) ou algum objeto para mostrar como alguma coisa se parece. Nas palavras de Clark, quando duas pessoas se encontram e uma delas cumprimenta a outra com um 'oi', ela usa o significado convencional de 'oi' para descrever sua ação como um cumprimento; usa sua voz e o

${ }^{16}$ Trato da noção de imaginação mais adiante. 
contato visual para indicar a si mesma como falante e o outro como interlocutor; e usa, normalmente, seu sorriso, olhos bem abertos e entoação para demonstrar entusiasmo (Clark 1996: 185). Essas estratégias não são dissociadas uma da outra no uso da língua em interação. Nesse sentido, Clark argumenta que essas estratégias não são entendidas separadamente, mas integradas, para significar, na situação em questão, grosso modo: 'eu cumprimento você com entusiasmo'.

Diferentes partes do corpo podem estar envolvidas no emprego de recursos semióticos relacionados à elaboração de descrições, indicações e demonstrações. Assim, não há, dessa perspectiva, uma distinção rígida entre usar, por exemplo, a palavra 'sim' ou fazer um aceno de cabeça para significar 'sim': tanto o emprego da palavra quanto do gesto descrevem a ação do falante como um ato de afirmação. A observação de situações reais de interação tem mostrado que, em geral, as pessoas empregam ambos os recursos simultaneamente (tanto a palavra 'sim' quanto o gesto), de modo que não faz sentido, dessa perspectiva, considerar apenas um deles. Nesse sentido, considera-se que diferentes partes do corpo participam, nos discursos presenciais, da elaboração de descrições, indicações e demonstrações, sempre visto de maneira integrada, constituindo um todo comunicativo.

\subsection{CONSTRUÇão CONJUNTA DE NARRATIVAS}

Duas noções, já introduzidas no início do capítulo, são importantes no estudo das narrativas: i) a narrativa é um tipo de discurso que evoca, através da sucessão de fatos, um mundo tido como real ou imaginário, situado em tempo e lugar determinados; o mundo evocado é uma elaboração discursiva de um narrador, que apresenta os fatos de uma maneira particular. Desse modo, o estudo de uma narrativa envolve aspectos relacionados, por um lado, ao mundo da narração, isto é, o mundo do qual o narrador e o narratário participam e, por outro lado, ao mundo narrado, ou seja, ao mundo do qual participam as personagens e demais elementos da história que está sendo contada. Entretanto, como dito inicialmente, no estudo de narrativas contadas presencialmente, um outro mundo precisa ser levado em conta: aquele da interação 'real', isto é, o mundo no qual as pessoas de carne-e-osso estão situadas, interagindo, durante a contação da história 
(McCleary \& Viotti, 2014). Esses mundos constituem diferentes domínios, que são independentes, mas estão sempre interconectados.

Enquanto estratégias comunicativas, os recursos usados para descrever, indicar e demonstrar podem estar relacionados tanto ao mundo real da interação, quanto ao mundo da narração e do narrado. Nesse sentido, a identificação do mundo a que um determinado recurso está vinculado é importante na construção da significação.

A situação de interação presencial constitui um primeiro domínio de ação (Clark, 1996) - que alguns autores denominam espaço semiótico da comunicação (Brandt \& Brandt, 2005; Oakley, 2009; citados por McCleary \& Viotti, 2014) ou espaço real (Liddell, 2003) - a partir do qual outros domínios de ação vão sendo elaborados. Para Liddell, esse domínio diz respeito à nossa conceitualização do espaço físico de enunciação, baseada nos estímulos sensoriais que recebemos do ambiente e combinada com o conhecimento de mundo. Trata-se, portanto, de uma primeira camada de significação construída nas interações, a partir da qual as demais camadas vão ser construídas. Para McCleary \& Viotti, numa perspectiva que leva em conta a interação material e social dos participantes da interação, esse domínio, que abrange a situação de enunciação, precisa ser considerado um espaço intersubjetivo, isto é, um espaço que tem como uma de suas assunções básicas a ideia de que a conceitualização que os participantes da comunicação fazem desse espaço é mutualmente coerente (2011: 295). O estabelecimento de um domínio conceitual comum se inicia com uma definição geral da situação por parte dos participantes da interação (i.e. o reconhecimento dos elementos que participam da interação e uma projeção mínima sobre a natureza da atividade que será realizada), e essa definição vai sendo ajustada à medida que a interação se desenvolve (Clark, 1996: 355). Assim, como as situações variam bastante, as atividades que as pessoas desenvolvem conjuntamente podem ser relativamente abertas a um ajuste local, no interior da micro-interação.

Para os fins desta discussão, convém observar especificamente um tipo de acordo realizado nas interações, que Clark denomina fingimento conjunto (joint pretense). De acordo com Clark, existem muitas atividades em que um fingimento conjunto é necessário para a definição da situação: crianças muito pequenas brincam e, durante as brincadeiras, elas sabem que estão só brincando: a boneca não é uma filhinha de verdade, o carrinho não serve para fazer uma viagem, etc. No mundo adulto, quando as pessoas assistem a uma peça de teatro, por exemplo, elas sabem que os artistas não são, de fato, 
as personagens da história; eles estão desempenhando papeis, que, ao final da peça, são desfeitos, voltando os artistas a ser as pessoas de carne-e-osso, e não mais as personagens ficcionais. No uso cotidiano da língua, os falantes também criam diversas estratégias para, dentre outras coisas, deixar as situações mais leves, descontraídas. Muitas vezes, as pessoas contam piadas, exageram, usam eufemismos, brincam, empregam ironias, dentre outros recursos. Para que esses usos da língua sejam corretamente interpretados, eles não podem ser tomados ao pé da letra. Em outras palavras, os interlocutores precisam se engajar num fingimento conjunto, e entender as expressões de modo não literal (Clark, 1996: 353), como num caso em que, em um dia nublado, alguém diz 'Que dia mais lindo, hoje!'. Seu interlocutor percebe que esse comentário é irônico, porque está envolvido no mesmo fingimento conjunto que o falante.

Para Clark, as narrativas são a forma mais primorosa de fingimento conjunto das interações comunicativas: os interlocutores (nas narrativas escritas, autor e leitor) precisam se engajar num fingimento conjunto para se coordenar na construção conjunta dos outros domínios ou mundos: o mundo da narração e o mundo da narrativa. Nessa construção conjunta, esses mundos constituem níveis de significação - ou domínios conceituais - diferentes, mas frutos de uma construção conjunta dos participantes da interação. ${ }^{17}$

\subsubsection{DOMÍNIOS DE AÇÃO EM UMA NARRATIVA PRESENCIAL}

Os domínios de ação podem ser concebidos como diferentes espaços mentais, que, no momento da elaboração de uma narrativa, vão sendo integrados, de modo a instanciar os diferentes níveis de intersubjetividade narrativa (McCleary \& Viotti, 2014). Cada um desses níveis constitui diferentes camadas de significação (Clark, 1996:

360). Espaços mentais, propostos por Fauconnier (1994; 1997), são estruturas conceituais, abstratas e dinâmicas, criadas e estruturadas à medida que pensamos ou falamos, para propósitos de ação local e entendimento (1997: 11). Os espaços mentais são estruturados por frames - que são 'molduras' nas quais encaixamos as nossas

$17 \mathrm{O}$ fato de narrativas serem uma construção ficcional não tem a ver com a veracidade da história, mas com o fato de que narrativas elaboram um mundo que, na maioria das vezes, não correspondente àquele mundo da enunciação em que a narração está acontecendo. 
experiências. Como visto acima, o domínio de ação em que ocorre a situação de interação presencial corresponde a um espaço mental que Liddell chama espaço real. É nele que se constrói a intersubjetividade de pessoas de carne-e-osso, ou seja, a de um 'autor real' ('falante' ou 'sinalizador') com seu 'interlocutor real'.

O segundo domínio de ação, que é o nível de intersubjetividade do mundo da narração, é, segundo McCleary \& Viotti (2010, 2011), o espaço resultante da integração entre elementos do primeiro domínio de ação (o espaço real) e elementos do frame de narrativa, que abrange os papeis de narrador e narratário, a história e as expectativas culturais a eles associadas. A criação desse espaço da narração nas histórias contadas presencialmente envolve primeiramente uma integração do corpo do falante/sinalizador com o papel de narrador. Em alguns casos, essa integração pode ser marcada pela mudança de postura corporal do sinalizador quando ele se prepara para contar uma história, isto é, quando se torna um |narrador| (McCleary \& Viotti, 2011: 298). ${ }^{18}$ Esse é o caso da narrativa que será analisada neste trabalho: é possível observar a mudança de postura corporal e expressões faciais no momento em que o sinalizador se torna narrador e começa a contar a história. Na Figura 4 abaixo, os quadros (a) até (e) correspondem ao primeiro domínio de ação, o espaço real em que o sinalizador interage com a pessoa para quem ele vai contar a história; no quadro (e) já pode ser notado o começo de uma mudança postural e de alteração das expressões faciais, que vão ficar mais claras entre os quadros (f) a (h), que refletem a integração do corpo do sinalizador com o papel de narrador. É a partir do quadro (f) que tem início o segundo domínio de ação, o mundo da narração:

18 Seguindo Liddell (2003) e vários autores que trabalham com a noção de integração conceitual (Dudis 2007, 2011; McCleary \& Viotti 2010, 2011; Barbosa 2013), uso as barras verticais para identificar entidades conceituais resultantes de alguma integração de espaços mentais. 


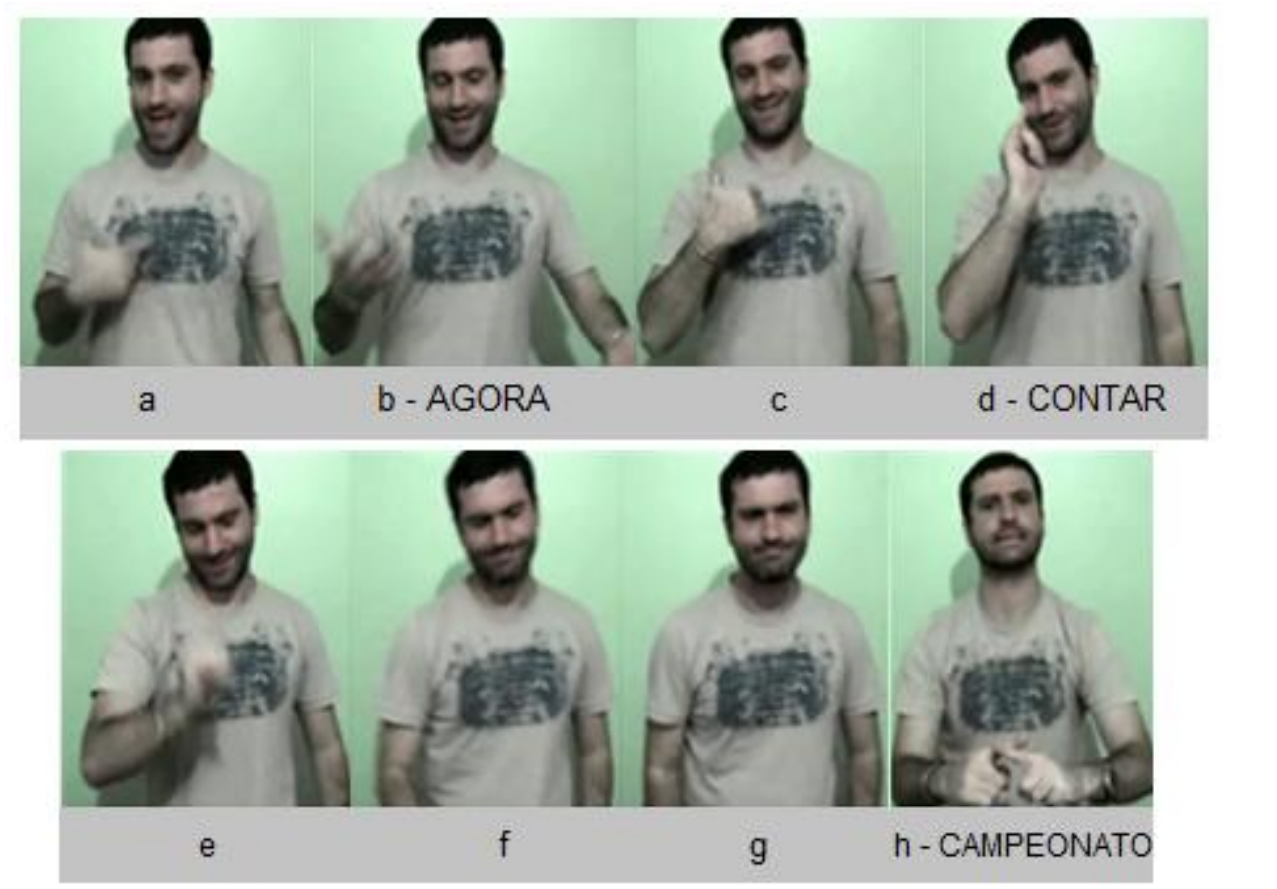

Figura 4 - Marcas gestuais da passagem para o espaço do narrador

Os domínios de ação das personagens são criados a partir da integração da figura do |narrador| com a caracterização de cada uma das personagens: seus traços psicológicos e socioculturais, suas atitudes, seus trejeitos e maneirismos, e suas ações. ${ }^{19}$ Em outras palavras, as personagens têm sempre, integradas a si, a figura do |narrador|, que, por sua vez, tem integrado a si o autor real (falante ou sinalizador). No caso de narrativas contadas face a face em língua sinalizada, McCleary \& Viotti propõem que os níveis de intersubjetividade narrativa - o do |narrador| e o das |personagens| - são sempre corporeados: eles são criados a partir de uma integração que necessariamente envolve um corpo sempre presente e em interação. A Figura 5, a seguir, ilustra, de acordo com a proposta de McCleary \& Viotti (2010, 2011), os níveis de intersubjetividade da narrativa sinalizada aqui analisada. ${ }^{20}$

\footnotetext{
${ }^{19}$ Para Liddell (2003), esse tipo de integração conceitual constrói um espaço mental integrado chamado espaço sub-rogado (p. 152).

20 A foto do jogador Jun Mizutani foi tirada da página da web a seguir: http://www.zimbio.com/pictures/ShHjuP9KoWs/Olympics+Day+3+Table+Tennis/VBgjsxgiqNy/Jun+Mizutani, $\quad$ vista em 07/06/2014.
} 


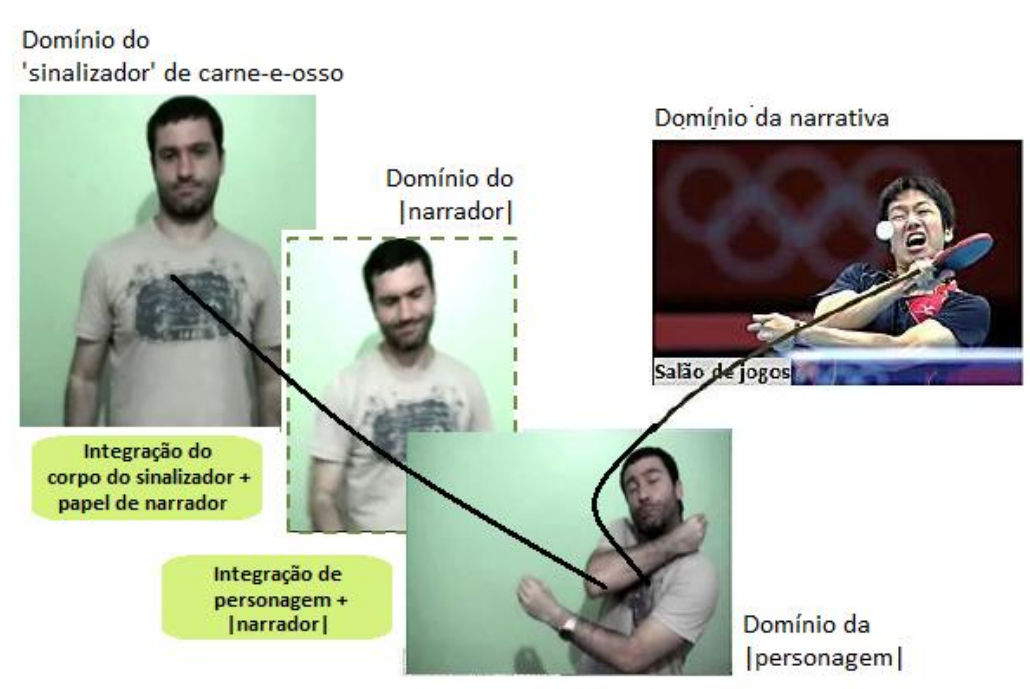

Figura 5 - Níveis de integração conceitual em uma narrativa sinalizada

O primeiro quadro superior à esquerda corresponde ao domínio do sinalizador de carne-e-osso; é nesse primeiro domínio conceitual de ação que os interlocutores, situados no ambiente, coordenam suas práticas corporeadas; a partir desse domínio os demais são elaborados: o segundo quadro, logo abaixo, contornado por linhas tracejadas, corresponde ao domínio do |narrador|, que é aquele que envolve uma integração entre o corpo do falante/sinalizador com o papel de narrador, criando a figura do |narrador|; o quadro que vem logo abaixo apresenta uma instância de demonstração criada a partir da integração conceitual entre o corpo da personagem, que, é um jogador de pingue pongue no quadro mais à direita, e o corpo do |narrador|, criando o corpo da |personagem|, por meio do qual o |narrador|, como ser visto no quadro inferior da figura, demonstra a ação realizada pela personagem no domínio da narrativa.

\section{DEMONSTRAÇÃo DE AÇÕES DO |NARRADOR|}

Uma vez que o falante/sinalizador tenha criado a figura do narrador, o |narrador| passa a contar a história, apresentando os fatos de sua perspectiva, da maneira como eles estão sendo vistos ou imaginados por ele. Na contação da história, o |narrador| emprega 
os recursos semióticos de diversas naturezas, apresentados anteriormente, para descrever, indicar e demonstrar as entidades e os eventos da narrativa. Um dos elementos conceituais importantes na elaboração da história é a posição de visualização (vantage point) que o narrador assume em relação às cenas da história que conta. ${ }^{21}$

A conceitualização de uma determinada situação envolve sempre uma determinada perspectiva assumida em relação à cena observada (Langacker, 2008). Em uma situação real de interação, a posição de visualização é a localização real do falante que descreve uma determinada cena que conceitualiza. Como as pessoas não se referem apenas a coisas que estão diante de si, a conceitualização de uma determinada cena pode não ser necessariamente equivalente àquela da situação real; os conceitualizadores podem imaginar uma cena ficcional e assumir uma posição de visualização em relação a ela. Outra razão para se assumir uma posição ficcional é o fato de que, sendo o espaço real um espaço intersubjetivo, as pessoas procuram, na comunicação, fazer um ajuste da conceitualização desse espaço, a fim de que a comunicação seja possível, como ilustrado pelo exemplo a seguir.

Quando, durante a discussão do texto na situação apresentada na Figura 3, Renata pergunta aos colegas “vocês viram onde eu deixei o meu copo?”, os colegas voltam a sua atenção para o ambiente, em busca do objeto. Encontrando o copo próximo à bolsa, eles podem responder à pergunta de diferentes maneiras, dependendo da posição que assumem em relação ao copo na conceitualização da cena (Langacker, 2008:76).

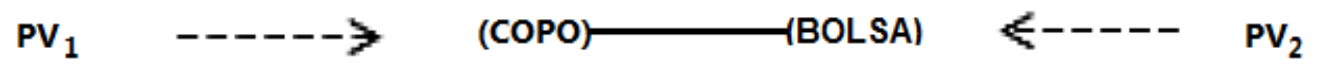

(a) PV1: O copo (trajetor) está na frente da bolsa (marco)

(b) PV2: $\mathrm{O}$ copo (trajetor) está atrás da bolsa (marco) A bolsa (trajetor) está na frente do copo (marco)

\footnotetext{
${ }^{21}$ Dudis (2007), buscando elementos para orientar a identificação de diferentes tipos de demonstrações (depictions) em ASL propõe que, além do corpo do sinalizador e do espaço em volta dele, outros três elementos conceituais participam das demonstrações: o sujeito (self), a posição de visualização (vantage point) e a temporalidade de eventos (temporal progression). Neste trabalho, seguindo a proposta de McCleary \& Viotti $(2010,2011)$ para identificação de níveis de intersubjetividade narrativa, associo esses elementos aos diferentes domínios conceituais mencionados. Em cada um dos domínios, os sujeitos - o interlocutor de carne-e-osso, o |narrador| ou alguma |personagem| - assumem posições de visualização próprias em relação às cenas das quais participam. Da mesma maneira, a temporalidade dos eventos pode estar associada tanto a ações do interlocutor de carne-e-osso quanto do |narrador|, de |personagens| ou de alguma outra entidade no domínio do narrado, como será apresentado nas análises.
} 
A cena descrita pelos enunciados acima envolve duas entidades - um copo e uma bolsa - que assumem proeminências diferentes em relação à outra em cada um dos enunciados. O trajetor é a entidade mais proeminente (i.e. a que assume a posição de figura na atenção do conceitualizador) e o marco é a entidade menos proeminente (i.e. a que fica como fundo nessa relação). Observada a posição de visualização diferente, a cena acima pode ser descrita de diferentes maneiras, a depender a posição assumida. Descrevendo a cena de sua própria posição de visualização, João (em PV ( $_{1}$ diria o enunciado em (a). Contudo, apesar de João ocupar sua própria posição de visualização em relação ao ambiente, uma vez que a conceitualização do espaço é intersubjetiva, ele leva em consideração a posição de Renata $\left(\mathrm{em} \mathrm{PV}_{2}\right)$, e, vendo que o copo está fora do campo de visão dela, responde "o copo está atrás da bolsa". O enunciado é seguido de um direcionamento do olhar para a localização onde está o copo. Observa-se, nesse caso, que, apesar de João realizar o apontamento a partir de sua posição de visualização real, ele descreve a localização do objeto a partir da posição de visualização de Renata.

Por causa da capacidade que temos de adotar uma posição de visualização ficcional diante de uma determinada cena, somos capazes de descrever situações da perspectiva do ouvinte ou de alguma outra entidade (Langacker, 2008: 76). Por isso, entende-se que, quando o falante/sinalizador assume o papel ficcional de |narrador|, junto com essa integração, ele assume também a |posição de visualização| ficcional do |narrador| diante dos fatos narrados. Do mesmo modo, quando o |narrador| integra alguma personagem da história, ele assume também a |posição de visualização| da |personagem| diante da cena de que a |personagem| participa. ${ }^{22}$ Nesse sentido, nas contações das histórias, as descrições, indicações e demonstrações podem servir como pistas tanto para a identificação da |posição de visualização| assumida pelo |narrador| quanto por alguma |personagem|.

Durante a contação da história, o |narrador| emprega tanto descrições quanto demonstrações, ambas acompanhadas por indicações, para apresentar os fatos da história, desde os mais concretos até os mais abstratos. Dentre os tipos de demonstrações realizados no domínio do |narrador|, estão aqueles realizados por gestos manuais icônicos,

\footnotetext{
${ }^{22}$ Essa é a configuração não-marcada de posições de visualização. Entretanto, há estratégias para alterar essa configuração, permitindo que narradores contem a história a partir de uma posição de visualização que não a sua, por exemplo. O chamado 'discurso direto livre' caracteriza-se justamente por ser uma estratégia em que, em meio à descrição feita pelo |narrador|, aparece a posição de visualização de uma personagem.
} 
amplamente empregados tanto em línguas orais quanto em línguas sinalizadas para apresentar algum aspecto sensorialmente perceptível em relação à história contada. Nos termos de Clark, as demonstrações oferecem uma experiência direta do referente, como se, ao ver a demonstração, o interlocutor estivesse vendo aquilo que é imaginado (1996: 174). Nesse sentido, Murphy (2004) argumenta que imaginação não pode ser entendida simplesmente como uma habilidade cognitiva individual, 'na mente' de cada indivíduo, mas tem que ser entendida também como uma ação conjunta, em que os participantes de uma interação se engajam. No ato imaginativo localizado em um contexto interativo, a ação de imaginar é sempre mediada por objetos: não só objetos mentais (e.g. imagens mentais), mas também objetos materiais - esses, sim, acessíveis aos interlocutores - como palavras, gestos e outros recursos semióticos, sem os quais os cenários imaginados não existiriam (2004: 269).

Para ilustrar, apresento um exemplo de demonstração realizada no nível do narrador, em que as interlocutoras - a jornalista Marília Gabriela e a atriz Adriane Galisteu - usam as mãos, antebraços e torso para imaginar uma cena juntas, como mostra a Figura 6 a seguir, vista no Youtube. ${ }^{23}$

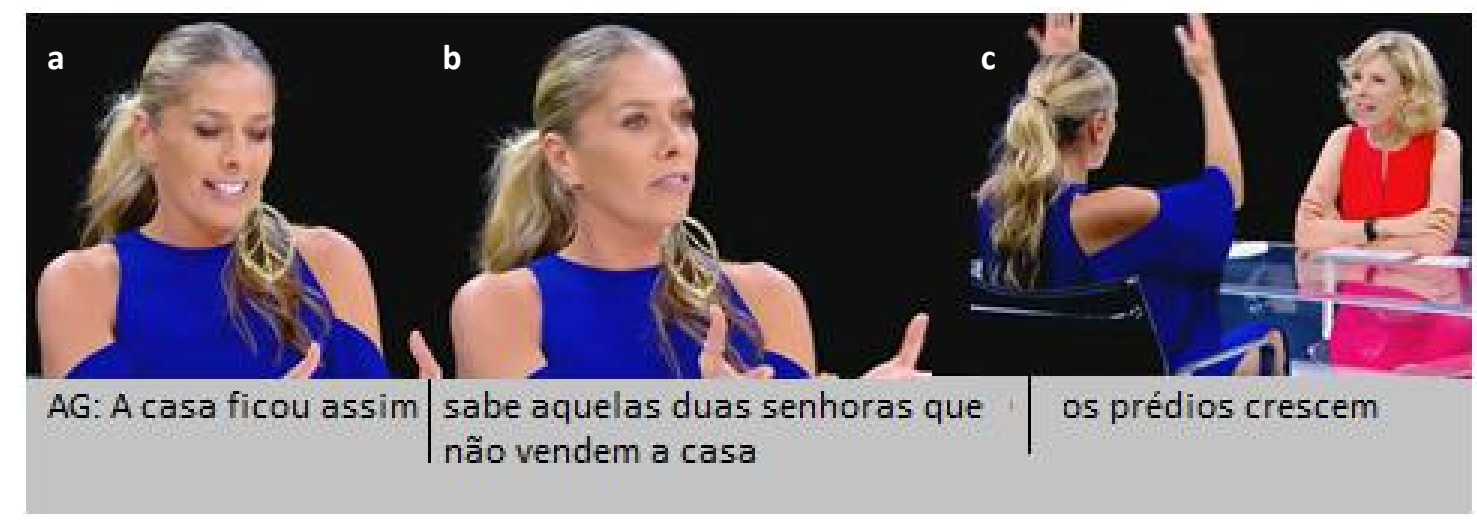

23 O trecho da entrevista apresentado na figura 6 pode ser visto a partir do link a seguir : http://surprise.ly/v/?loMDGxGbMRc:171:178:0:100, que seleciona do site do Youtube esse momento da entrevista. Visto por último em 03/06/2014. 


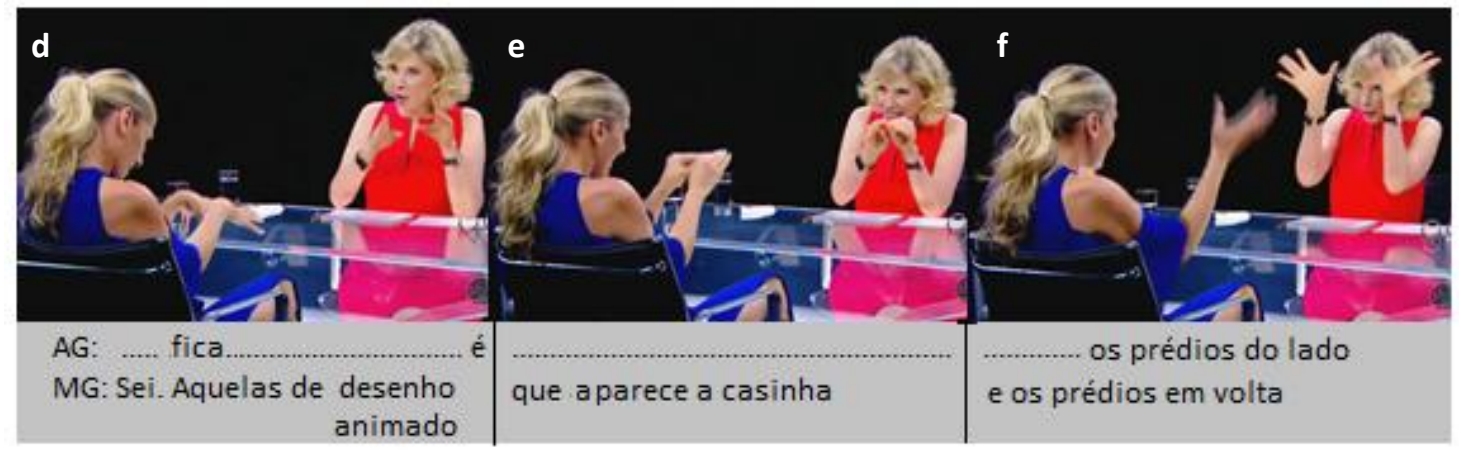

Figura 6 - Demonstração realizada por gesto manual simultâneo à fala oral

No exemplo acima, Adriane Galisteu está explicando como ficou, depois que o bairro se desenvolveu, a situação atual da casa em que ela morou. No quadro (a), enquanto diz 'a casa ficou assim', ela olha para as próprias mãos, que, nesse momento, estão abertas e posicionadas lado a lado, na altura do peito. O posicionamento das mãos no espaço, acompanhado do direcionamento do olhar para as mãos e do enunciado verbal, parece sugerir que a falante imagina, no espaço na frente do seu corpo, a cena que será descrita. Se entendermos que Adriane Galisteu está elaborando um cenário de dimensão reduzida em frente ao seu corpo, é possível pensar que o direcionamento do olhar para as mãos seja entendido como a |posição de visualização| que o |narrador| assume em relação à cena que irá apresentar. ${ }^{24}$

Em seguida, no quadro (b), Adriane Galisteu olha para sua interlocutora e propõe, pelo enunciado verbal, que ela imagine a situação em que duas senhoras não vendem a casa. No quadro (c), simultâneo ao enunciado verbal 'os prédios crescem', a falante realiza um gesto icônico que demonstra aspectos visuais do enunciado verbal: com as

\footnotetext{
${ }^{24}$ A inferência de que um (cenário| imaginado está sendo elaborado em dimensão reduzida parece ser feita a partir do reconhecimento de dois fatores, como i) o nosso conhecimento de que as entidades imaginadas em frente ao corpo são muito menores do que as entidades representadas são no mundo 'real', tomando como parâmetro a escala humana; ii) se há alguma | posição de visualização| interna ao |cenário| (Dudis, 2007: 16). Embora Dudis não leve em consideração a figura do |narrador| em suas análises, a partir do seu trabalho, pode-se entender que os dois fatores acima se relacionam do seguinte modo: se, ao demonstrar uma entidade como, por exemplo, um |prédio| em frente ao seu corpo, o |narrador| olha para o alto, inferimos que, esse |prédio|, em relação ao corpo do |narrador|, tem proporções reais; a posição de visualização é, portanto, interna ao |cenário| em que o prédio está localizado; se, por outro lado, ao demonstrar a localização de um |prédio|, o |narrador| olha para baixo (ou, por exemplo, mantém contato visual com o |narratário|), essa pode ser uma pista de que o |cenário| está sendo conceitualizado em dimensão reduzida e, nesse caso, a |posição de visualização| do |narrador| é externa a esse |cenário|. A análise a respeito da |posição de visualização|, neste trabalho, difere da análise de Dudis por levar em consideração a figura do |narrador|.
} 
mãos posicionadas palma a palma, a falante realiza dois movimentos seguidos, de baixo para cima; enquanto o posicionamento das mãos parece sugerir iconicamente o formato do prédio, os movimentos de baixo para cima sugerem que os prédios crescem. No quadro (d), a entrevistada ainda continua elaborando a cena: ela diz 'fica' e posiciona as mãos abertas, viradas para baixo, à altura do peito, e faz um movimento curto para baixo ao localizá-las, sugerindo, com esse gesto, que a |casa| imaginada está posicionada naquele lugar. Observe-se que as mãos são posicionadas numa altura muito inferior à do gesto anterior, usado para representar os prédios. Esse posicionamento das mãos sugere iconicamente a altura das casas em relação aos prédios.

No quadro (d), Marília Gabriela reconhece a cena imaginada por sua entrevistada como sendo semelhante a 'aquelas de desenho animado', e se engaja ativamente na imaginação conjunta da cena. No quadro (e), enquanto encolhe os ombros e diz 'que aparece a casinha', Marília Gabriela faz um gesto manual icônico com as duas mãos, que se assemelha ao telhado de uma casinha. Nesse momento, é possível ver que as interlocutoras estão imaginando a cena juntas; nos quadros (e) e (f), elas realizam exatamente os mesmos gestos: ambas encolhem os ombros (o que contribui com o significado de que a casinha ficou espremida entre os prédios) e realizam, ambas, gestos manuais icônicos muito semelhantes, simultaneamente, para representar a $\mid$ casinha| e os |prédios|. Nesse caso, o |cenário| parece ser elaborado da |posição de visualização| do |narrador|, que não está inserido nesse |cenário| de dimensão reduzida, diante do corpo, mas observa-o de fora.

Como sugerem as análises apresentadas por Dudis, uma |posição de visualização| pode ser inferida não apenas a partir dos apontamentos que o |narrador| ou as |personagens| realizam em direção às entidades no |cenário|, mas pela organização conceitual que o |narrador| dá ao espaço na localização das |entidades| que participam do |cenário| (2007: 12). Ainda no exemplo em questão, para organizar o espaço da demonstração, Marília Gabriela desloca o torso um pouco para a esquerda e localiza as mãos mais à esquerda, para significar a localização da |casinha| e (apesar de o desvio rápido do olhar para as mãos não ser capturado pela figura em (e)) olha rapidamente para as mãos enquanto localiza a |casinha|, o que nos faz inferir a |posição de visualização| do |narrador|. Dito de outro modo, infere-se que o |narrador| esteja organizando o |cenário| de sua perspectiva, isto é, da maneira como ele o vê/imagina durante a elaboração da 
demonstração. ${ }^{25}$ Nesse sentido, o posicionamento do torso e a localização das mãos também servem como pistas para reconhecer a |posição de visualização| do |narrador| diante da cena. Como o |cenário| é elaborado da |posição de visualização| do |narrador|, cada uma das falantes assume uma |posição de visualização| diante do |cenário| que elaboram juntas. Contudo, embora cada uma assuma uma |posição de visualização| diante do |cenário|, essas posições parecem ser mutuamente compatíveis na elaboração conjunta da cena imaginada.

De maneira semelhante ao que acontece no exemplo anterior, nas línguas sinalizadas, os sinalizadores também fazem uso significativo do espaço para demonstrar aspectos visuais da história. Ainda em relação às demonstrações no nível do |narrador|, observemos alguns exemplos de demonstrações em libras, sinalizados por uma colaboradora, nativa em libras, no início de minha pesquisa. ${ }^{26} \mathrm{O}$ exemplo apresentado na Figura 7, a seguir, foi observado no início de uma narrativa em que o |narrador| inicia a história contando que uma mulher está na cobertura do prédio.

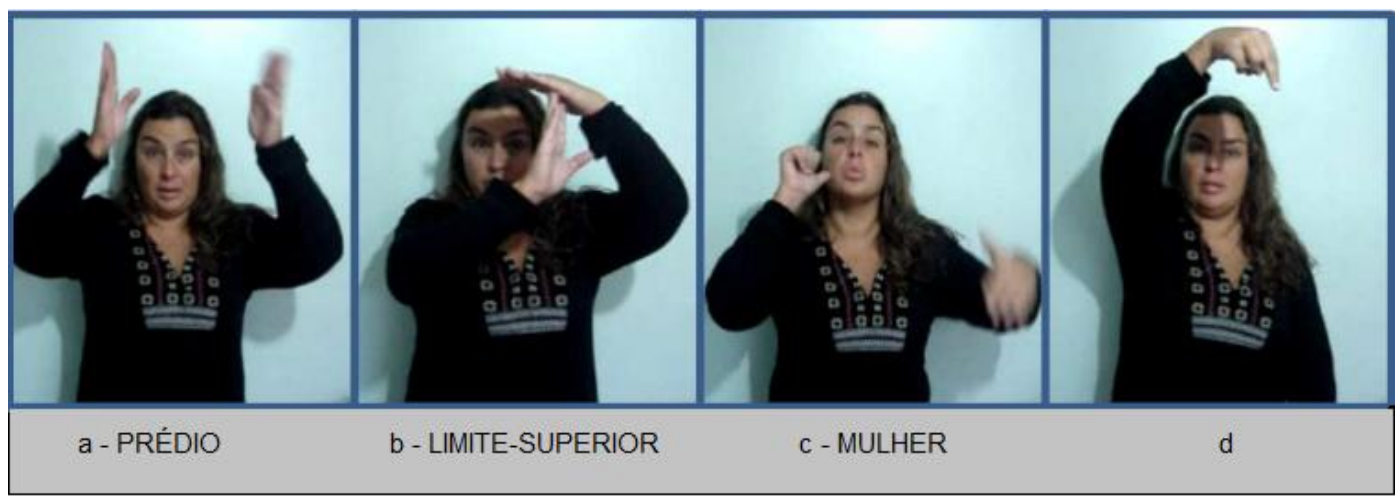

Figura 7 - Demonstração em libras no nível do |narrador|

Nesse exemplo, o |narrador| imagina a cena da história, em que há uma mulher na cobertura do prédio. Para apresentar o cenário da história, o |narrador| inicia a história

\footnotetext{
${ }^{25}$ Murphy (2004) propõe que a imaginação, enquanto ação conjunta, deve ser entendida como uma forma de percepção em modo hipotético. Nesse sentido, pode-se dizer que o |narrador| não revela sua | posição de visualização| somente quando 'olha' para alguma |entidade | no |cenário| que elabora; uma vez que a própria organização do |cenário| também revela o modo como o |narrador| o imagina, a própria organização do |cenário| dá pistas para reconhecer como o |narrador| percebe, em modo hipotético, esse |cenário|.

${ }^{26}$ Agradeço imensamente à Sylvia Lia por me fornecer os exemplos observados em situações de uso e por permitir o uso de sua imagem nesta dissertação.
} 
usando o sinal PRÉDIO e, em seguida, usa o sinal LIMITE-SUPERIOR à altura da cabeça, numa localização não prototípica, onde ele imagina a |cobertura do prédio| no |cenário| da história. ${ }^{27}$ Em seguida, o |narrador| usa o sinal MULHER e, depois, uma demonstração, realizada com o fim de localizar a |mulher| na região onde a |cobertura do prédio| foi imaginada. O gesto em (d) é normalmente usado para demonstrar a localização de pessoas num |cenário|, pois o formato que a mão assume se assemelha ao das pernas de uma pessoa em pé. Nesse exemplo, a pista que temos para identificar a posição de visualização do |narrador| é a localização das mãos nos quadros (b) e (d), que sugerem que o |narrador| está elaborando o |cenário| em dimensão reduzida e que assume, portanto, uma |posição de visualização| externa ao |cenário|. Nesse trecho, não há direcionamento do olhar em relação à localização da |mulher| no |cenário| da história.

Uma vez que, como argumenta Clark (1996: 185), as descrições, indicações e demonstrações não aparecem isoladamente, mas sempre integradas no uso da língua, podemos ver que os sinalizadores, mesmo quando descrevem algum evento, podem, simultaneamente, demonstrar alguns aspectos da história. No exemplo em questão, podemos observar que, mesmo usando o sinal PRÉDIO para descrever o cenário da história, o |narrador| parece aproveitar a iconicidade do sinal para realizar o sinal seguinte LIMITE-SUPERIOR, na região onde ele imagina estar a |cobertura do prédio|. Não parece ser coincidência o fato de o sinal LIMITE-SUPERIOR ser realizado próximo à região em que as mãos terminam a realização do sinal PRÉDIO, para elaborar o espaço conceitual de |cobertura do prédio| na região acima da cabeça. O aproveitamento da iconicidade do sinal para localizar outras entidades associadas durante a construção do |cenário| da história parece ser comum em narrativas sinalizadas. Um outro exemplo pode ser visto na Figura 8, apresentada a seguir, em que o |narrador| conta que as luzes do prédio se apagaram instantaneamente.

\footnotetext{
${ }^{27}$ A localização prototípica desse sinal é ao centro do espaço de sinalização, à altura do peito.
} 


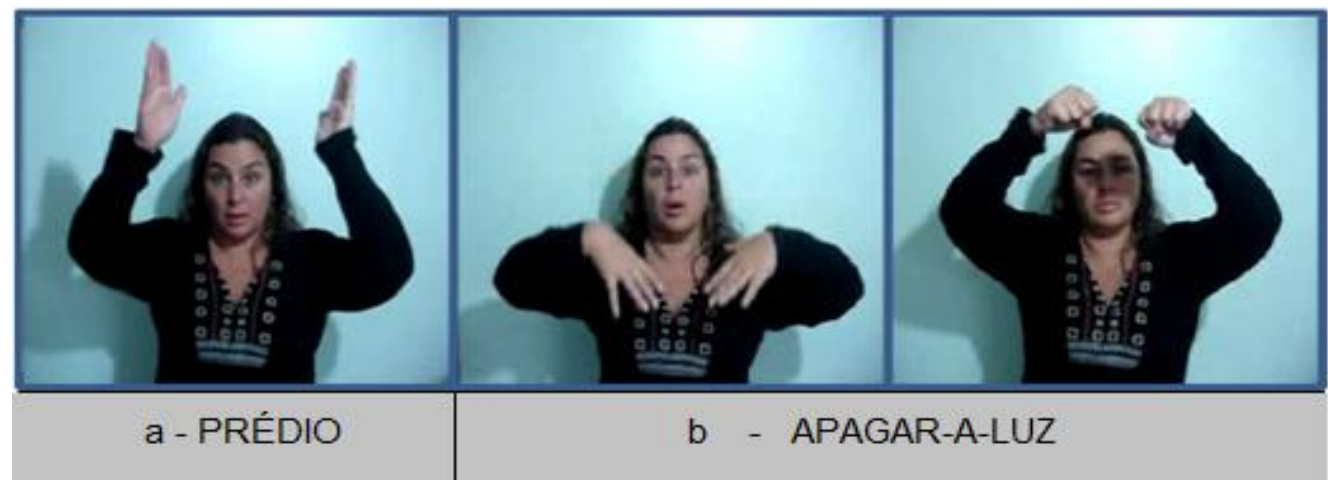

Figura 8 - Demonstração em libras no nível do |narrador|

De modo semelhante ao que acontece no exemplo anterior, no exemplo apresentado na figura acima, o sinal PRÉDIO descreve o lugar onde o evento se passa. Para dizer que as luzes do prédio se apagaram de uma só vez, o |narrador| usa o sinal APAGAR-A-LUZ, realizando uma demonstração de que todas as luzes se apagaram instantaneamente: o |narrador| inicia a realização do sinal à altura do peito e, subindo as mãos em um movimento linear e fechando ambas as mãos rapidamente, termina o movimento na região acima da cabeça. ${ }^{28} \mathrm{O}$ movimento linear de baixo para cima, realizado pelo sinal APAGAR-A-LUZ sugere que todas as luzes do prédio, de todos os andares, se apagaram. Observe-se que, no início da realização do sinal APAGAR-A-LUZ, o |narrador| mantém os olhos bem abertos, fechando-os durante a realização do sinal e apertando os lábios, o que contribui com o significado elaborado pela demonstração realizada pelo sinal manual, de que as luzes se apagaram instantaneamente.

Além das demonstrações de elementos concretos da narrativa - cenários, personagens, ações - os |narradores| podem ainda elaborar demonstrações mais abstratas, para ilustrar alguns aspectos visuais do que está sendo descrito ou para ajudar na própria organização do discurso. ${ }^{29} \mathrm{Na}$ sua tipologia de demonstração em ASL, elaborada a partir de revisão de categorias já descritas na literatura das línguas de sinais, Dudis (2011) elenca alguns tipos de demonstração abstrata reconhecidos no discurso das línguas sinalizadas, dentre as quais, apresento aquela que Dudis menciona como plano-

\footnotetext{
${ }^{28} \mathrm{O}$ sinal é prototipicamente realizado com uma única mão, posicionada à altura da cabeça ou à altura do peito, dependendo de que fonte a luz é proveniente (se é uma lâmpada em um cômodo da casa ou se é uma lâmpada de abajur, por exemplo).

${ }^{29}$ Um exemplo de demonstração abstrata usada para organização do discurso é apresentado no capítulo 4.
} 
calendário (descrita inicialmente por Engberg-Pedersen, 1993; citada por Dudis), ilustrada pelo exemplo a seguir, em que o |narrador| comenta que em todo o Brasil, não há intérpretes formados, como visto na Figura 9. ${ }^{30}$
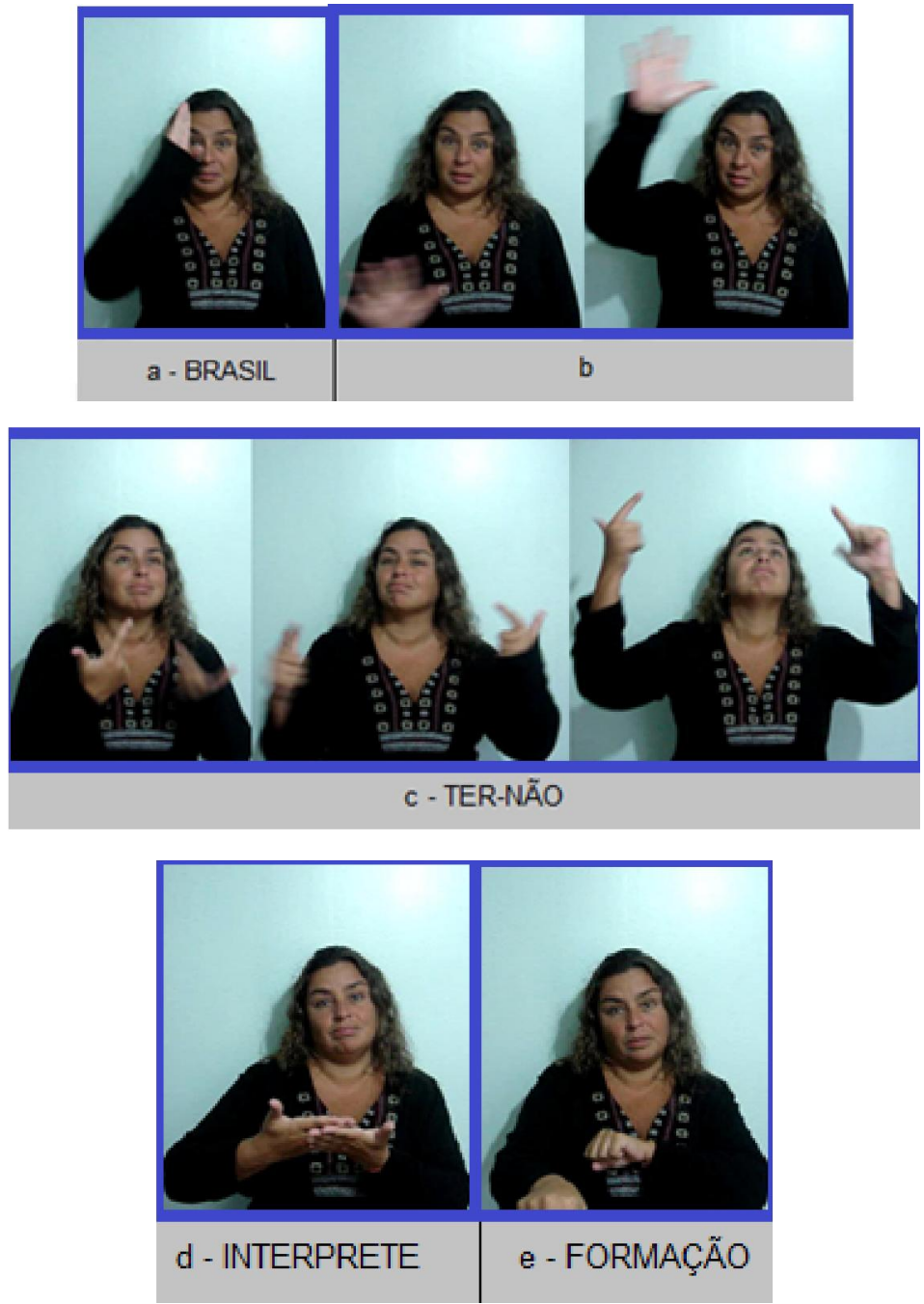

Figura 9 - Demonstração de 'plano calendário' em libras no nível do |narrador|

Nesse exemplo, o |narrador| inicia o seu comentário com o sinal BRASIL, no quadro (a), que descreve a região onde se passa a eventualidade descrita. Em seguida, o

\footnotetext{
30 Esse tipo de demonstração é denominado 'plano-calendário', porque, nele, se faz uma exploração bidimensional do espaço de sinalização, como se existisse um calendário imaginário em frente ao corpo do sinalizador; apesar da especificidade do termo, essa demonstração cria outros planos imaginários, como o gesto deste exemplo, que sugere a criação de um mapa imaginário.
} 
|narrador| usa o gesto apresentado no quadro (b) para especificar que é de todo o Brasil que ele está falando. $\mathrm{O}$ uso do gesto em (b) envolve imaginar a região em frente ao corpo como uma região plana, bidimensional, como a de um mapa. Seguido do sinal BRASIL, esse gesto sugere que todo o espaço pela qual a mão percorre é, na construção desse mapa imaginário, a área pertencente ao Brasil. Em seguida, o |narrador|, usando as duas mãos, diz, no quadro (c), que não há, usando o sinal TER-NÃO, com um movimento não prototípico. ${ }^{31}$ Observe-se que, na realização desse sinal, a iconicidade do gesto anterior é aproveitada e, dando ao sinal um movimento direcional de baixo para cima, o |narrador| contorna, com as duas mãos, o mapa imaginário que ele havia, previamente, construído na sua frente. Como pode ser observado no primeiro e no último quadro de (c), o |narrador| olha para cima durante a realização do sinal, o que, nesta análise, é interpretado como uma evidência para o reconhecimento da |posição de visualização| do |narrador| diante do |mapa| imaginário que ele demonstra em sua frente. O sinal TER-NÃO, realizado com esse movimento não prototípico, não só descreve a eventualidade como também demonstra, contornando o espaço, toda a região imaginária onde a eventualidade se passa. Por fim, o |narrador| realiza, nos quadros (d) e (e), os sinais INTÉRPRETE e FORMAÇÃO, respectivamente, que complementam o verbo TER-NÃO, significando que não há intérpretes formados. O dicionário Capovilla \& Raphael considera que o que foi realizado no quadro (b) é um sinal, de nome FEDERAL. Mesmo já tendo sido dicionarizado, o entendimento de que o que ocorre em (b) constrói um mapa imaginário é fundamental para explicar a realização do sinal NÃO-TER e a direção da cabeça e do olhar da sinalizadora.

\section{DEMONSTRAÇÃO DE AÇÕES DE |PERSONAGENS|}

Durante a elaboração de uma demonstração de ações de uma |personagem|, o |narrador| usa o seu corpo e o espaço em torno de si para demonstrar as expressões,

\footnotetext{
${ }^{31} \mathrm{O}$ sinal NÃO-TER é, prototipicamente, realizado com a mão direita em L, localizado à altura do ombro direito, palma para a esquerda, balançado a mão pelo pulso para baixo algumas vezes.
} 
sentimentos e ações das personagens da história e, a partir do posicionamento do corpo, a localização que as |personagens| assumem no |espaço da história|. ${ }^{32}$ Nesse sentido, esse tipo de demonstração não pode ser entendido como sendo uma cópia das ações da personagem, mas sim como uma construção que o |narrador| faz dessas ações (McCleary \& Viotti, 2011: 298).

Como dito anteriormente, a elaboração de uma demonstração de ações de |personagens| envolve uma integração de elementos do espaço da história a elementos do espaço da narrativa, isto é, uma integração entre o corpo de alguma personagem da história e o corpo do |narrador|, como no exemplo a seguir, em um trecho em que o |narrador| pergunta se é correto capturar borboletas para colocar em quadros, apresentado na Figura 10.
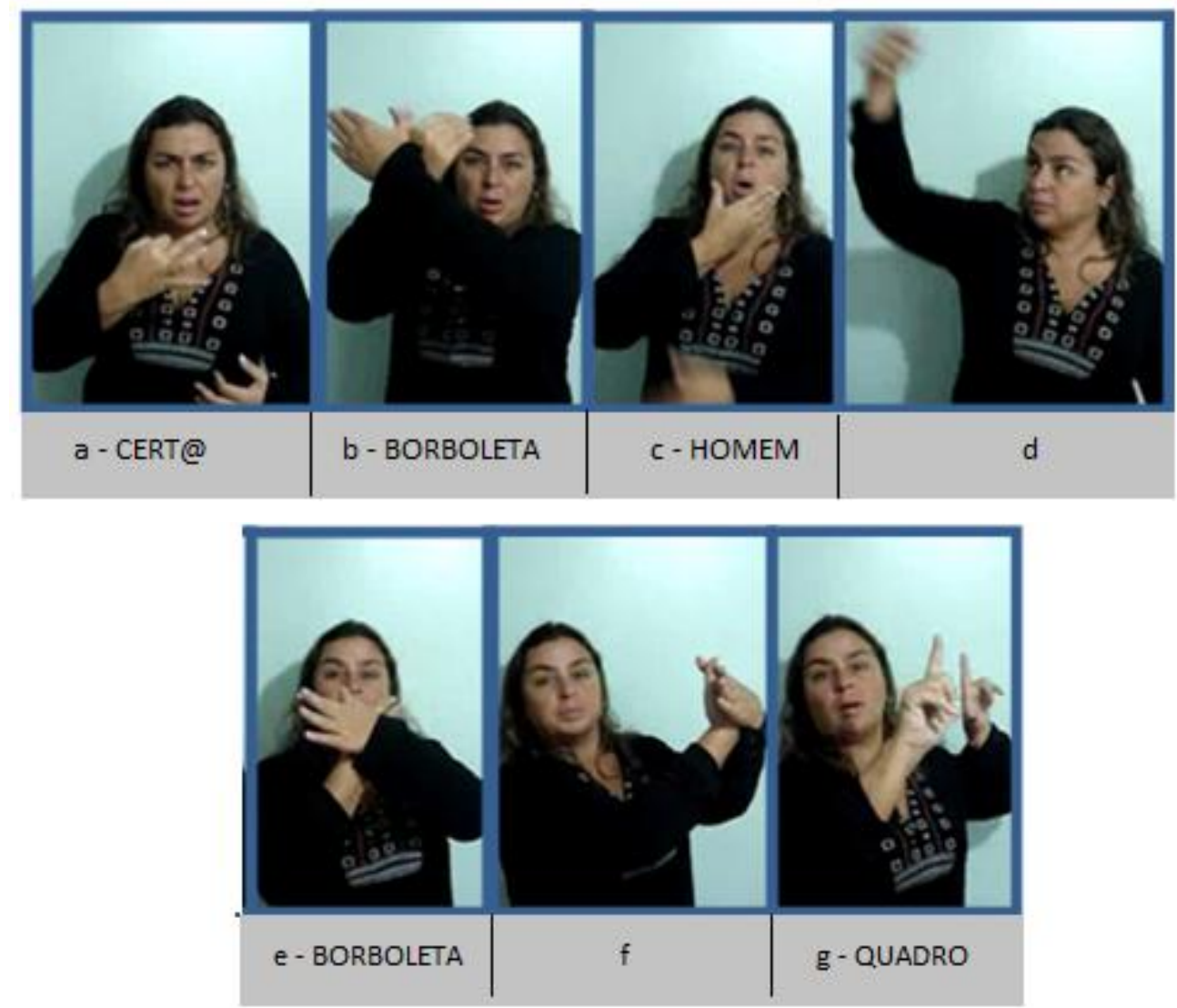

Figura 10 - Demonstração em língua sinalizada no nível do |narrador| e no nível da |personagem |

\footnotetext{
32 Esse tipo de demonstração nas narrativas é aquele que ficou conhecido como 'ação construída'
} (Metzger, 1995; citada em Liddell, 2003). 
$\mathrm{O}$ |narrador| inicia esse trecho, no quadro (a), perguntando se é certo e, no quadro (b), usa o sinal BORBOLETA numa localização não prototípica para demonstrar a localização das borboletas no |cenário| imaginado, com um ligeiro desvio do olhar do contato visual com o |narratário| durante a realização do sinal BORBOLETA. ${ }^{33}$ Em seguida, o |narrador| usa o sinal HOMEM e, no quadro (d), usa o seu corpo para demonstrar o |homem| capturando |borboleta|. Observe que, uma vez que o |narrador| já tinha demonstrado a localização da |borboleta| na região à direita e acima da cabeça, o gesto usado no quadro (d) - que se assemelha a alguém pegando algo com o auxílio de algum instrumento - é entendido como sendo a demonstração da ação de 'pegar a borboleta' realizada pela |personagem|. Uma vez que uma |personagem| da história esteja integrada ao corpo do |narrador|, as ações realizadas, bem como a postura corporal e as expressões faciais e o direcionamento do olhar para cima e para a direita são entendidas como sendo da |personagem| da história. Durante a realização de uma demonstração de ação de personagem, sabemos que a |personagem| integrada ao corpo do |narrador| não está num vácuo, mas no espaço da história que o narrador está contando. Por isso, o espaço em torno do corpo do |narrador| passa a ser entendido como sendo o |cenário da história|. Nesse caso, há uma integração entre o espaço em torno do |narrador| e o espaço da história. Observe-se que, no quadro (d), o olhar direcionado para cima é o da |personagem| que, assumindo uma |posição de visualização| específica diante da cena da história, olha as |borboletas| que está capturando, localizadas naquele espaço conceitual.

No quadro (e), o |narrador| repete o sinal BORBOLETA e, no quadro (f), realizando um movimento curto para frente com as mãos ainda configuradas como no sinal BORBOLETA, demonstra que a |borboleta| foi colocada na região à esquerda, que, no quadro (g), o |narrador| diz que é onde está o quadro (localizando o sinal de QUADRO também com um movimento curto para frente, numa região não prototípica, isto é, onde ele imagina a localização do |quadro|). Observa-se que, nos quadros (e), (f), e (g), o corpo do |narrador| está conceitualmente partido: enquanto o |narrador| olha para o |narratário|,

\footnotetext{
${ }^{33}$ Esse enunciado foi produzido duas vezes, na sequência. Na primeira realização, a |narradora| desvia o olhar do contato visual que mantém com o |narratário| e olha para a região à direita e acima de sua cabeça, onde imagina a localização das |borboletas|. Esse direcionamento do olhar é entendido como sendo olhar do |narrador| que, assumindo uma |posição de visualização| diante do |cenário| em tamanho real, olha para as |borboletas| imaginárias, naquela região espaço. Na segunda realização do enunciado, a |narradora| desvia o olhar sutilmente do contato visual com o |narratário|, mas não chega a olhar para aquela região.
} 
o torso do |narrador| virado para a esquerda parece sugerir que o |narrador| ainda integra a |personagem|, isto é, a posição do corpo nos quadros (f) e (g) demonstra que é a |personagem| que está colocando as |borboletas| no |quadro|.${ }^{34}$ As mãos do |narrador| também estão conceitualmente partidas e são entendidas como sendo a |borboleta| e não as mãos da |personagem| que segura a |borboleta|. ${ }^{35}$

À medida que a história se desenrola, as |personagens| podem também assumir o papel de |narrador| e contar, elas mesmas, uma história dentro da história que está sendo contada, introduzindo novas |personagens| etc. Desse modo, novos domínios de ação são elaborados recursivamente. No caso de o |narrador| estar demonstrando a ação de uma personagem narrando, a própria fala/sinalização da |personagem| faz parte da demonstração. Dito de outro modo, dentre os vários aspectos que o |narrador| demonstra quando cria a ação de uma personagem, inclui-se o próprio ato de a personagem produzir um enunciado, com mais ou menos detalhes a respeito do modo como o enunciado foi produzido. Aquilo que a literatura, de modo geral, chama discurso direto não é outra coisa que não uma demonstração de fala das personagens (Clark \& Gerrig 1990: 764).

\subsection{CONSIDERAÇõeS FINAIS}

O objetivo deste capítulo foi discutir uma abordagem descritiva para o estudo de narrativas multimodais elaboradas em situações de interação face a face. As especificidades das narrativas contadas face a face (seja em línguas orais ou sinalizadas) requerem que se adote uma abordagem descritiva apropriada para o estudo desse tipo de narrativa, que leve em consideração os elementos presentes nesse tipo de produção: a copresença de participantes da interação comunicativa em um ambiente potencialmente significativo e as múltiplas relações que se estabelecem a partir dessa copresença, que são Corpo/Corpo/Mundo, Fala/Fala/Mundo e Corpo/Corpo/Fala/Fala (Hutchins, 2010).

\footnotetext{
34 O conceito de partição do corpo foi inicialmente proposto por Liddell (2003) e desenvolvido por Dudis (2004), e vem sendo empregado por autores que estudam os discursos sinalizados, para dar conta da simultaneidade de recursos empregados nos discursos sinalizados (Liddell, 2003; Dudis, 2004; 2007; McCleary \& Viotti, 2010; 2011).

${ }^{35}$ Esse tipo de demonstração de manuseio de coisas, em que a mão representa iconicamente a coisa manuseada, e não a mão que manuseia, já foi amplamente descrito pela literatura das línguas sinalizadas sob vários rótulos, dentre eles, instrumental classifier (Supalla, 1986: 196).
} 
No cenário de multimodalidade que se instaura a partir dessas relações, as pessoas realizam atividades conjuntas e coordenam as suas ações nas diversas atividades conjuntas situadas. Abordei a questão, explicitando como se dá a interação das pessoas entre si e com o ambiente em que elas estão presentes, quais são alguns dos elementos cognitivos e interacionais que participam na construção dos significados e de que modo os participantes da interação se engajam para a construção do mundo da narração e da narrativa.

Discuti, ainda, a noção de língua em uso adotada neste trabalho: o uso da língua é parte de um todo comunicativo que envolve muito mais do que o emprego de enunciados linguísticos: vozes e movimentos de corpos entram na composição desse todo comunicativo e são igualmente importantes na construção dos significados elaborados em situação de interação face a face (McCleary, 2011). Vimos que, segundo a proposta de Clark (1996) para observação de língua em uso de uma perspectiva multimodal, os interlocutores precisam se coordenar na elaboração de três estratégias comunicativas diferentes: a descrição, a indicação e a demonstração, cada uma delas associada a uma estratégia cognitiva diferente, a formas diferentes de coordenação de ações e ao uso de elementos semióticos de natureza diversa.

A observação das interações e da língua em uso dessa perspectiva é favorecida pelos instrumentos de que dispomos para o registro, transcrição e disponibilização de dados dessa natureza. No próximo capítulo, apresentarei, então, os aspectos metodológicos de uma abordagem descritiva para o estudo de narrativa multimodal: a obtenção dos dados multimodais, a transcrição dos dados e a apresentação dos dados usados nesta pesquisa. 


\section{METODOLOGIA PARA O ESTUDO DE NARRATIVAS SINALIZADAS NUMA PERSPECTIVA MULTIMODAL}

\subsection{INTRODUÇÃO}

De uma perspectiva multimodal, o estudo das situações de interação face a face envolve três facetas de coordenação de ação depreendidas das relações que se estabelecem entre os elementos Corpos/Falas/Mundo (Hutchins, 2010). Como mencionado no capítulo anterior, o estudo dessas relações (Corpo/Corpo/Mundo; Fala/Fala/Mundo; Corpo/Corpo/Fala/Fala), geralmente implica um recorte, seja porque, em uma determinada atividade conjunta, uma dessas relações é mais saliente do que as outras, seja por questões de ordem metodológica, como, por exemplo, o estabelecimento de quais são as perguntas relevantes em uma determinada pesquisa. Neste trabalho, um recorte bastante específico do sistema de multimodalidade é feito: observa-se aqui como, em uma narrativa sinalizada, o sinalizador conta uma história sobre um jogo de pingue pongue e, dentre os recursos semióticos que ele usa na sua contação, como ele elabora as demonstrações das entidades e eventos da narrativa. Os aspectos da multimodalidade mais relevantes para a análise são, portanto, a relação Fala/Corpo - na medida em que descrição e demonstração estão integradas na elaboração da história - e a relação Corpo/Mundo - na medida em que o sinalizador usa o espaço de sinalização para realizar demonstrações, que, por sua vez, são atuações, na narrativa, de ações correspondentes no mundo. A relação Fala/Mundo também está presente, naturalmente, na construção da referência, mas essa relação é muito menos explorada, neste trabalho, do que as primeiras.

Como discutido anteriormente, a narrativa é um tipo de discurso em que os narradores descrevem situações, reais ou inventadas, e elementos nelas envolvidos: as personagens, suas ações e as demais eventualidades nas quais as personagens estão envolvidas. Como foi dito, na contação de histórias presencialmente elaboradas, diferentemente de narrativas escritas, o narrador está corporalmente presente e, por isso, 
pode usar o corpo para demonstrar aspectos perceptíveis da história que está contando: muito daquilo que em narrativas escritas precisa ser descrito, nas narrativas presencialmente elaboradas pode ser demonstrado. ${ }^{36}$ Parece haver, contudo, uma diferença entre narrativas presenciais orais e sinalizadas em relação aos elementos empregados: nas histórias contadas em línguas orais, os fatos da narrativa são, fundamentalmente, descritos. Apesar de, nessas narrativas, as demonstrações acompanharem as descrições, ilustrando aspectos perceptíveis da história, os enunciados linguísticos são fundamentais para a organização e estruturação da história. Em narrativas sinalizadas, por sua vez, a correlação de forças parece se inverter: a organização da narrativa depende fundamentalmente da organização conceitual do espaço de enunciação e da ação de um corpo nesse espaço conceitualmente organizado, sendo apenas parcialmente elaborada por meios propriamente linguísticos (McCleary \& Viotti, 2014). Nesse sentido, as demonstrações têm um papel muito importante para a organização de narrativas em línguas sinalizadas.

Diante disso, o desafio metodológico que se impõe às análises multimodais de narrativas sinalizadas é justamente o de discutir uma abordagem descritivamente adequada a essa modalidade de narrativa, levando em consideração a necessidade de capturar os elementos que contribuem para a organização da narrativa e para a construção do significado. Um cuidado metodológico com os dados das línguas sinalizadas ainda se faz mais evidente porque, como notam Bolgueroni \& Viotti (2013), ainda se sabe muito pouco sobre o efeito que a modalidade gesto-visual das línguas de sinais pode ter sobre sua gramática e sobre sua organização discursiva (p. 32). O registro e a transcrição dos dados têm impacto direto nas análises de língua em uso, pois eles impõem um recorte sobre aquilo que o analista tem à sua disposição para observação.

O objetivo deste capítulo é discutir alguns aspectos metodológicos de uma abordagem descritiva para narrativas sinalizadas numa perspectiva multimodal. Nessa discussão, faço uma primeira apresentação dos dados analisados nesta pesquisa e discuto as tecnologias de registro e manipulação de dados multimodais

usadas para a análise. Na seção sobre dados, apresento a fonte da qual obtive dados para essa pesquisa; na seção sobre transcrição, apresento o modelo de transcrição proposto

\footnotetext{
${ }^{36}$ Poyatos (2002) mostra o quanto há, em narrativas escritas, de descrição de elementos não verbais; sem essas descrições do não dito seria muito difícil reconstruir as cenas imaginárias da narrativa.
} 
por McCleary, Viotti \& Leite (2010) para dados de língua sinalizada, com refinamentos apresentados em Barbosa (2013), alguns dos quais elaborados a partir de revisões de McCleary (2013); ${ }^{37}$ e, finalmente, na seção de apresentação dos dados, mostro como os dados serão dispostos no capítulo de análise, de modo a facilitar a leitura do próximo capítulo.

\subsection{NARRATIVA MULTIMODAL SINALIZADA}

\subsubsection{DADOS}

A narrativa estudada nesta pesquisa, intitulada "Bolinha de Ping Pong", de autoria de Rimar Segala, é parte de uma série de narrativas produzidas pela $C \& A$ Arte \& Silêncio e disponibilizadas no site do Youtube. Nesta pesquisa, não fiz propriamente coleta de dados; optei por trabalhar com uma narrativa de autoria de um surdo, tratando de um assunto de interesse dele, em um vídeo que tivesse sido, preferencialmente, disponibilizado pelo próprio autor numa base virtual pública da internet. A primeira razão foi justamente porque, ao início da pesquisa, eu tinha um objeto de estudo bem preciso e, naquele momento, não era possível saber se, ao gravar uma narrativa qualquer, meu objeto de estudo apareceria nos dados em quantidade suficiente. Por isso, resolvi partir da busca por vídeos no Youtube que apresentassem bastantes ocorrências do objeto de estudo. Quatro narrativas foram escolhidas, sendo que apenas uma delas foi analisada nesta dissertação.

Além da vantagem de saber que poderia contar com um número suficiente de ocorrências para a minha análise, a escolha por trabalhar com um vídeo disponibilizado no Youtube apresenta uma outra: uma vez que as análises sejam disponibilizadas, os leitores poderão acessar facilmente o dado de origem e verificar a fonte em mídia eletrônica, podendo ver a realização linguística do dado analisado em todos os detalhes de realização, pelo menos enquanto o vídeo permanecer disponível. Apesar de a referência a bases de dados multimodais ser pouco frequente, um número razoável de pesquisadores, em diferentes áreas, começa a fazer uso de bases de dados dessa natureza, sendo a base de dados do Youtube cada vez mais citada em pesquisas acadêmicas

\footnotetext{
${ }^{37}$ As alterações mais recentes do modelo foram apresentadas pelo Prof. Dr. Leland McCleary no curso 'Multimodalidade na interação face a face' (2013), e já estão sendo incorporadas em trabalhos de membros do grupo de pesquisa (cf. Barbosa 2013).
} 
(Kousha, Thelwall \& Abdoli, 2012). Cabe lembrar que a busca em bases de dados virtuais não é, de todo, rara em trabalhos linguísticos. Quando as análises são baseadas em textos escritos, por exemplo, é comum que os pesquisadores façam pesquisa em buscadores da internet para a verificação de dados em uso (por exemplo, a frequência de uso de uma determinada expressão escrita, servindo, por exemplo, como indicador de uso da expressão).

\subsubsection{TRANSCRIÇÃO DOS DADOS}

Depois da obtenção da autorização do autor para o estudo da narrativa, a transcrição foi realizada por meio do software de transcrição de vídeo ELAN (EUDICO Linguistic Annotator), criado pelo Laboratório de Psicolinguística do Instituto Max Planck. Nesse software, é possível incluir um ou mais vídeos e criar trilhas, nas quais as anotações podem ser feitas em sincronia com o vídeo. Por meio dessa ferramenta, é possível fazer anotações e acessá-las facilmente durante a análise através de uma lista gerada pelo software. Além disso, o ELAN dispõe de diversas funcionalidades que facilitam a operação do material, como, por exemplo, ferramentas de controle de velocidade do vídeo, o que possibilita a observação da narrativa em velocidade reduzida. A Figura 11, a seguir, mostra uma imagem da tela do ELAN, com trilhas já criadas e anotações já feitas.

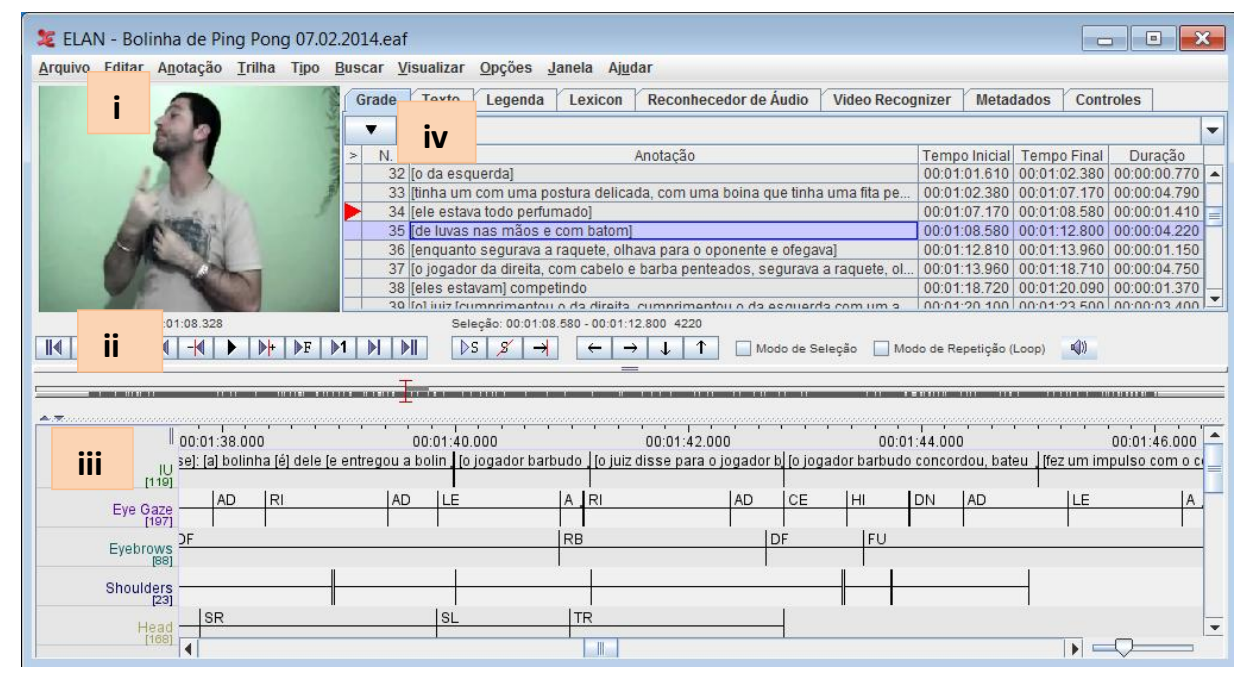

Figura 11 - Tela do ELAN com a narrativa analisada neste trabalho 
Na tela apresentada na Figura 11, pode-se observar (i) uma imagem do vídeo da narrativa analisada; (ii) os botões de controle para diversos tipos de avanços e retrocessos no vídeo; (iii) as trilhas de transcrição com anotações já feitas; e (iv) a lista das anotações feitas em uma das trilhas.

O sistema de transcrição adotado para anotar os dados de língua sinalizada, como foi dito, é o proposto por McCleary, Viotti \& Leite (2010), com refinamentos apresentados em Barbosa (2013), seguindo orientações propostas por McCleary (2013). Esse modelo de transcrição permite que as anotações sejam feitas com um bom nível de detalhamento e padronização, de modo a permitir análises linguísticas de diversos níveis gramaticais e discursivos. Uma característica importante desse sistema de transcrição é o de que ele é eminentemente descritivo: há trilhas para registrar o que é realizado pelas diferentes partes do corpo do sinalizador, sem que seja imposto nenhum tipo de rótulo relacionado a qualquer eventual análise.

A tabela a seguir apresenta as trilhas do modelo de transcrição de McCleary, Viotti \& Leite (2010) usadas neste trabalho. Para os propósitos específicos desta pesquisa, foi importante o uso de todas as trilhas do sistema para a anotação de movimentos de partes do corpo, visto que eles são parte da realização dos diferentes tipos de demonstração.

\begin{tabular}{l|l|l}
\hline \multicolumn{1}{c}{ Trilhas } & $\begin{array}{c}\text { Vocabulário } \\
\text { Controlado }\end{array}$ & \\
\hline IU & & Registro das unidades ideacionais/entoacionais \\
\hline Body & $\bullet$ & Registro de movimentos do tronco \\
\hline Shoulders & $\bullet$ & Registro de movimentos dos ombros \\
\hline Head & $\bullet$ & Registro de movimentos da cabeça \\
\hline Eyebrow & $\bullet$ & Registro de movimentos das sobrancelhas \\
\hline Eyelids & $\bullet$ & Registro de movimentos das pálpebras \\
\hline Eyegaze & $\bullet$ & Registro da direção do olhar \\
\hline Mouth gestures & $\bullet$ & $\begin{array}{l}\text { Registro de movimentos bucais sem relação com } \\
\text { a língua portuguesa }\end{array}$ \\
\hline H-location & $\bullet$ & $\begin{array}{l}\text { Registro da localização das mãos no espaço de } \\
\text { sinalização }\end{array}$ \\
\hline Dictionary & $-\begin{array}{l}\text { Registro da página do dicionário Capovilla e } \\
\text { Raphael em que o sinal encontra-se descrito }\end{array}$ \\
\hline Mouth pictures & Registro de visemas \\
\hline Comments & $\begin{array}{l}\text { Registro de comentários de qualquer natureza } \\
\text { surgidos durante a transcrição }\end{array}$ \\
\hline
\end{tabular}

Tabela 2 - Trilhas utilizadas do sistema de transcrição proposto por McCleary, Viotti \& Leite (2010) 
Para transcrever o que acontece nas ocorrências de demonstração, utilizo as trilhas da tabela acima. Na primeira coluna, estão os nomes das trilhas; na segunda coluna, estão marcadas as trilhas em que é feito uso de vocabulário controlado, isto é, um repertório de possibilidades de anotações pré-determinadas, representadas por siglas, que tem como objetivo promover uma padronização das informações; na terceira coluna, encontra-se a descrição de cada trilha.

Seguindo o modelo de transcrição, primeiramente realizei uma segmentação da narrativa em partes menores, feita por identificação de unidades entoacionais. Prossegui com a transcrição de cada uma das partes do corpo. Conforme sugere o modelo, fiz uma descrição minuciosa do que é feito com a cabeça, torso, ombros, braços, e, na face, sobrancelhas, pálpebras, direção do olhar e boca, em cada momento do discurso, utilizando as trilhas apresentadas na tabela acima, sem impor nenhuma interpretação ao dado observado.

Além das trilhas apresentadas na tabela acima, incorporo algumas alterações mais recentes do modelo, que dizem respeito fundamentalmente à forma de anotar os sinais/gestos manuais, que, anteriormente, era feita em uma única trilha e, agora, é feita em trilhas separadas para cada uma das mãos. Para este trabalho, a vantagem das mudanças da versão mais recente do modelo para a registro das mãos é que, reconhecendo a intensa interação entre elementos linguísticos e gestuais nos discursos sinalizados, o modelo permite não só a anotação e segmentação dos sinais, isto é, dos elementos propriamente linguísticos, mas de quaisquer movimentos feitos pelas mãos. Isso se mostra adequado para pesquisas que, como esta, consideram que sinais e gestos são significativos e contribuem para a estruturação da narrativa. $\mathrm{O}$ registro das mãos, que antes era feita em uma trilha, agora se desmembra nas trilhas nas trilhas da mão direita (R-Hand) e da mão esquerda (L-Hand).

A tabela a seguir mostra as novas trilhas empregadas para transcrever o movimento das mãos. Como pode ser visto na tabela, além da bipartição das mãos, foram incluídas trilhas para anotação das unidades gestuais, fases gestuais, tipo de gesto e descrição do gesto de cada uma das mãos. 


\begin{tabular}{|c|c|c|}
\hline Trilhas & $\begin{array}{l}\text { Vocabulário } \\
\text { Controlado }\end{array}$ & Descrição \\
\hline G-Unit-1-LH & & Unidades gestuais realizadas pela mão esquerda \\
\hline GPhases-1-LH & $\bullet$ & Fases gestuais realizadas pela mão esquerda \\
\hline HandG-type-1-LH & - & $\begin{array}{l}\text { Classificação do tipo de gesto realizado pela } \\
\text { mão esquerda de acordo com as categorias de } \\
\text { McNeill e algumas outras categorias }\end{array}$ \\
\hline HandG-descr-1-LH & & $\begin{array}{l}\text { Descrição do gesto ou registro da glosa do sinal } \\
\text { realizado pela mão esquerda }\end{array}$ \\
\hline H-location-1-LH & $\bullet$ & $\begin{array}{l}\text { Local da realização, no espaço de sinalização, } \\
\text { da fase expressiva do gesto realizado pela mão } \\
\text { esquerda (registrado apenas quando há alguma } \\
\text { variabilidade de localização) }\end{array}$ \\
\hline G-Unit-1-RH & & Unidades gestuais realizadas pela mão direita \\
\hline GPhases-1-RH & $\bullet$ & Fases gestuais realizadas pela mão direita \\
\hline HandG-type-1-RH & $\bullet$ & $\begin{array}{l}\text { Classificação do tipo de gesto realizado pela mão } \\
\text { direita de acordo com as categorias de McNeill e } \\
\text { algumas outras categorias }\end{array}$ \\
\hline HandG-descr-1-RH & & $\begin{array}{l}\text { Descrição do gesto ou registro da glosa do sinal } \\
\text { realizado pela mão direita }\end{array}$ \\
\hline H-location-1-RH & $\bullet$ & $\begin{array}{l}\text { Local da realização, no espaço de sinalização, } \\
\text { da fase expressiva do gesto realizado pela mão } \\
\text { direita (registrado apenas quando há alguma } \\
\text { variabilidade de localização) }\end{array}$ \\
\hline
\end{tabular}

Tabela 3 - Novas trilhas para o registro dos movimentos das mãos, revisto por McCleary (2013)

A seguir, apresento detalhadamente como cada uma das trilhas do modelo foi empregada neste trabalho.

\section{UNIDADES ENTOACIONAIS DA NARRATIVA}

Por causa da dificuldade de observar o discurso contínuo, é útil segmentar a narrativa em partes menores. No estudo de narrativas escritas (ou, no caso de narrativas orais transcritas), é comum que a delimitação de unidades mínimas de uma narrativa seja feita por orações. Em trabalhos como o de Labov \& Walezky (1967), por exemplo, as orações são consideradas unidades mínimas do discurso narrativo. Uma das dificuldades de trabalhar com o discurso sinalizado é justamente o fato de que ainda há poucos critérios linguísticos estabelecidos para orientar a segmentação do discurso em unidades mínimas 
em línguas sinalizadas. ${ }^{38}$ Diante disso, a proposta do modelo de transcrição utilizado é que se faça uma segmentação do discurso em unidades entoacionais (Chafe, 1994). De acordo com Chafe, as unidades entoacionais são unidades de processamento cognitivo e linguístico, fundamentais para a constituição do discurso (1994: 57). Nesse sentido, McCleary, Viotti \& Leite (2010) sugerem, então, que esse tipo de segmentação é mais fundamental, sobretudo nos discursos face a face, já que neles a segmentação em orações tem um papel secundário.

A identificação de unidades entoacionais no discurso sinalizado é feita de maneira empírica. Leite (2008) e Leite \& McCleary (2013), buscando pistas que possam servir de evidência para a delimitação de fronteiras entre unidades, elencam algumas marcas manuais e não manuais observadas em um estudo inicial baseado em conversas em libras. Em relação às marcas manuais, eles apontam o alongamento final do sinal/gesto, que pode ser i) a manutenção da suspensão final do sinal, ou ii) a reiteração dos movimentos repetitivos internos do sinal. Em relação aos sinais não manuais, os autores falam em marcas mais pontuais, como i) piscada de olhos, e ii) acenos de cabeça; e marcas menos pontuais, como i) expressões faciais, ii) posicionamentos e/ou movimentos da cabeça/tronco; e iii) direcionamento e/ou movimentos do olhar. A Figura 12, a seguir, ilustra um exemplo de delimitação de uma unidade entoacional retirado da narrativa. ${ }^{39}$

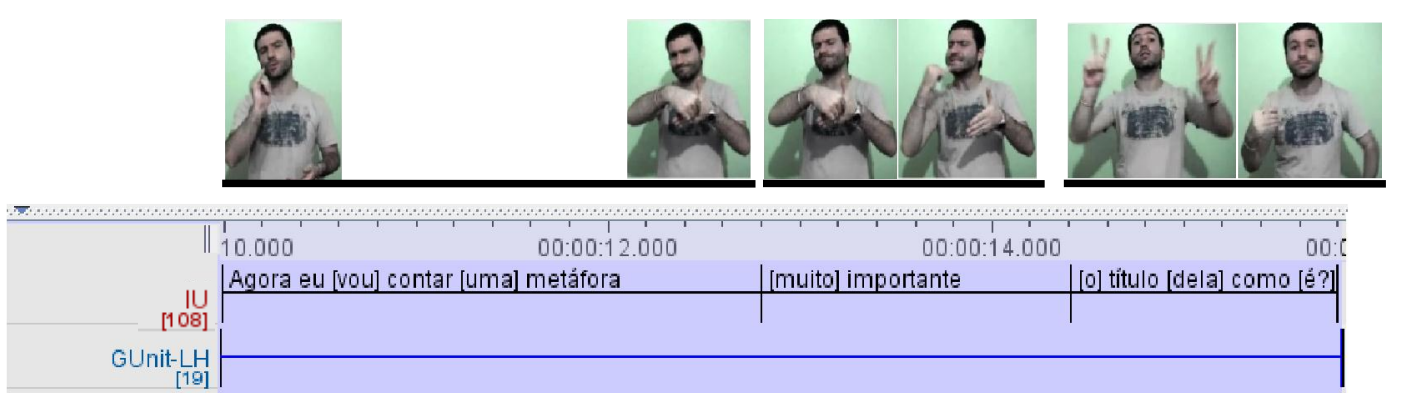

Figura 12 - Trilha de divisão da narrativa em unidades entoacionais

\footnotetext{
38 Leite (2008) é um primeiro esforço no sentido de buscar empiricamente marcas de segmentação em libras. Ver também Leite \& McCleary (2013).

${ }^{39}$ A IU é uma linha que corresponde a uma divisão mais ideacional do que propriamente entoacional, pois ela toma por base a tradução e adaptação ao português daquilo que foi dito em libras. São necessários mais debates sobre essa tradução adaptada para fazer avançar o modelo de transcrição que está sendo usado nesta dissertação. Agradeço ao Prof. Leland McCleary e ao Prof. Tarcísio Arantes Leite por essa observação.
} 
$\mathrm{Na}$ figura acima, apresento as três primeiras unidades entoacionais que iniciam o discurso. Para separar essas unidades, observei as marcas manuais e não manuais produzidas pelo sinalizador. Em relação à primeira unidade entoacional da narrativa, a delimitação da unidade naquele ponto do discurso foi feita pela observação de três marcas co-ocorrentes: a manutenção da suspensão final do sinal manual, um aceno de cabeça e o início de mudança na expressão facial. Na segunda unidade, há duas marcas menos pontuais: a cabeça se movimenta como em um aceno (como no movimento de cabeça de 'não') e o sinalizador mantém os olhos fechados. A marcação do limite final dessa unidade foi feita no momento em que o sinalizador abre os olhos, olha para o interlocutor e muda sua expressão facial. Nesse momento, considero o início uma nova unidade entoacional, que se encerra quando o sinalizador leva suas mãos para a posição de repouso.

$\mathrm{Na}$ narrativa aqui analisada foram identificadas cento e oito unidades entoacionais. Conforme sugerido no modelo de transcrição, nas traduções para o português, coloquei entre colchetes as palavras que não têm correspondentes entre os sinais manuais realizados, mas que são necessárias à boa formação do texto em português. Somado a isso, entre colchetes também foram acrescentadas algumas informações inferidas a partir dos sinais não manuais ou do contexto. Uma vez que grande parte das demonstrações é realizada por gestos não manuais, decidi colocar também entre colchetes as ocorrências de demonstração identificadas na narrativa. Para distingui-las daquelas informações usadas para cumprir exigências do português na boa formação da sentença, as ocorrências de demonstração estão anotadas em itálico nesta dissertação e, no ELAN, que não aceita esse tipo de fonte, elas são anotadas entre barras inclinadas. A seguir, apresento as traduções para o português das unidades entoacionais identificadas na narrativa, cada uma delas em uma linha.

O discurso foi dividido, por questões metodológicas, em três grandes blocos: o primeiro é a apresentação da narrativa, antes de ela ser propriamente iniciada; o segundo é a constituição do cenário com a introdução das personagens; e, finalmente, o terceiro é a ação das personagens. Dentro do segundo bloco, pode-se ainda dividir a constituição do cenário em duas partes: a que introduz e caracteriza o ambiente, e a que introduz e caracteriza as personagens. O terceiro bloco também pode ser dividido entre ação dos jogadores, ação/fala da bolinha, ação do juiz e ação da plateia. Por fim, há a 'fala' do narrador, que encerra a história com um aceno de cabeça para o narratário, esperando dele 
uma opinião ou sugestão a respeito do que foi contado. Apresento, abaixo, a divisão dos

blocos, juntamente com a apresentação das unidades entoacionais da narrativa. ${ }^{40}$

\section{Apresentação}

Agora eu [vou] contar [uma] metáfora

[muito] importante

[o] título [dela] como [é?]

[em] português

[é] B-O-L-I-N-H-A

$\mathrm{D}-\mathrm{E}$

P-I-N-G P-N ${ }^{41}$

Como [é o sinal em libras?]

[é] PINGUE-PONGUE

[bolinha]

Esta $[$ bolinha $]$

[é uma] metáfora, ela [é] incrível

ela tem

[o] que

[essa] metáfora [é uma] comparação [com a] vida [de] nós [todos]

[gesto (I): aceno de cabeça acompanhado de assopro forte]

[gesto (II): aceno de cabeça acompanhado de gesto bucal]

Eu agora eu [vou] contar

[gesto: mudança na postura corporal e expressão facial]

${ }^{40}$ Conforme observado pelo Prof. Leland McCleary na banca, é importante ressaltar que a tradução das demonstrações nas unidades entoacionais promove uma simplificação das demonstrações, uma vez que detalhes importantes das demonstrações não aparecem na tradução, como maneirismos, posições de visualização, precisão na organização espacial de cenários, dentre outros.

${ }^{41}$ É comum, nos casos em que a palavra pode ser entendida com menos itens do alfabeto, que o surdo não soletre toda a palavra. 


\section{Constituição do cenário e introdução de personagens}

[no] campeonato [de] pingue pongue

[a] arquibancada [está repleta]

[ao centro, há uma mesa de pingue pongue, que tem uma rede]

[e, ao redor dela, as pessoas ocupam toda a arquibancada]

[em frente à mesa, está em pé], [o] juiz

[está em pé, em frente à mesa]

[tem alguém do lado esquerdo da mesa]

[e alguém do lado direito da mesa]

[ a pessoa da direita e a da esquerda estão] competindo

[os dois jogadores estão ofegantes, o da direita e o da esquerda, posicionados um em frente ao outro]

\section{Caracterização das personagens}

[o da direita]

[está com o corpo virado para a esquerda, olhando para o oponente, e ofega]

[é um sujeito que tem uma barba enorme e um cabelo enorme, que emenda com a barba, e dá até para pentear a barba]

[o jogador da direita]

[o da esquerda]

[tem uma postura delicada, com uma boina que tem uma fita pendurada e um arranjo enorme]

[ele está todo perfumado]

[de luvas nas mãos e com batom]

[o jogador da direita, com cabelo e barba penteados, segura a raquete, olha para o oponente e ofega]

[eles estão] competindo

[o] juiz [com expressão séria e costas eretas, cumprimenta o jogador da direita e o jogador da esquerda com um aceno de cabeça]

Introdução de personagem 'bolinha de pinque ponque'

[e pega a bolinha] 
[um nariz de palhaço]

[a] bolinha, ela [é uma] pessoa [com] nariz de palhaço

[que diz] tudo bem! [para o juiz]

[o juiz fala para a bolinha]: agora, [você é] dele [do jogador da direita]

[a bolinha disse: ah, eu, bolinha, sou dele?]

[o] barbudo

[diz]: [a] bolinha [é] minha!

\section{Ações do jogo}

Primeiro lance

[o narrador conclui]: [a] bolinha [é] dele [do jogador barbudo] [e o juiz entrega a bolinha para o jogador da direita]

[o jogador barbudo pega a bolinha]

[o juiz diz para o jogador barbudo que ele inicie o jogo]

[o jogador barbudo concorda, bate a bola na mesa algumas vezes]

[faz um impulso com o corpo e lança a bolinha com a raquete, fortemente]

[a bolinha bate duas vezes na mesa e o jogador delicado]

Ação inesperada: o jogador delicado sequra a bolinha com a mão

[pega a bolinha, segura-a na mão]

[as] pessoas [se viram e] olham [para o jogador delicado espantadas]

[o] juiz [se vira e olha para o jogador delicado espantado]

[o barbudo se vira e olha para o jogador delicado espantado]

[o jogador delicado segura a bola na mão]

[o juiz reprova e diz: não, jogue a bola]

Reinício do joqo: ações dos joqadores

[o jogador delicado, meio contrariado, aceita: bate a bola duas vezes na mesa e lança a bolinha]

[o jogador barbudo olha para a bolinha, preparando-se]

[a bolinha bate na mesa] 
[e o jogador barbudo joga]

[o jogador delicado rebate]

[o jogador barbudo bate]

[o jogador delicado rebate]

[o jogador barbudo bate]

[o jogador delicado rebate]

[o jogador barbudo bate]

[o jogador delicado rebate]

Movimentos da bolinha no cenário

[a bolinha vai para a esquerda, para a direita, para a esquerda, para a direita, para a esquerda]

[o] juiz [olha para a direita, para a esquerda, para a direita, para a esquerda]

[a] bolinha [se move para a direita, para a esquerda, para a direita, para a esquerda, para a direita, para a esquerda, para a direita, para a esquerda]

[o] juiz [olha para a direita, para a esquerda, para a direita, para a esquerda]

[a plateia olha para a direita, para a esquerda, para a direita, para a esquerda, para a direita, para a esquerda, para a direita, para a esquerda ]

[a] bolinha [se move para a esquerda, para a direita, para a esquerda, para a direita, para a esquerda]

Ações dos joqadores

[o jogador barbudo bate na bola]

[o jogador delicado rebate]

[o jogador barbudo bate]

[o jogador delicado rebate]

Movimentos da bolinha no cenário

[a bolinha vai para um lado, para o outro lado, para um lado, para o outro lado, para um lado, para o outro lado]

[a raquete bate na bolinha para um lado, para o outro lado, para um lado, para o outro lado, para um lado, para o outro lado]

Ações dos jogadores e movimentos da bolinha do cenário: 'câmera lenta' 
[o jogador barbudo bate a bola ['câmera lenta']]

[o jogador delicado rebate a bolinha ['câmera lenta']]

[o jogador barbudo bate na bola ['câmera lenta']]

[a bolinha que se move], ela

[recebe um tapa do lado direito do rosto]

[um tapa do lado esquerdo do rosto]

[um tapa do lado direito]

[e] olha [para o juiz]

[e leva um tapa no lado esquerdo]

[e o] juiz

[troca olhares com a bolinha, enquanto ela é rebatida da direita para a esquerda e da esquerda para a direita]

Diálogo entre a bolinha e o juiz

[a bolinha diz para o juiz]: [me] ajuda

[e leva outro tapa no lado direito do rosto]

[a bolinha diz]: [me] ajuda [me] pega

[e o] juiz [acena com a cabeça que 'sim']

[o jogador delicado rebate a bolinha]

Ação do juiz: interrupção do jogo

[e o] juiz

[vê a bolinha vindo da esquerda, estende o braço]

[e pega a bolinha]

[a bolinha, ela]

Ação da bolinha: fim da 'câmera lenta'

[para na mão do juiz, com um impacto brusco [retomada da velocidade normal de ação]]

Ação do juiz

[o juiz segura a bolinha]

[o juiz olha para a bolinha, enquanto ele a balança na mão] 
[oferece a bolinha para o jogador delicado]

[oferece para o jogador barbudo]

\section{Encerramento}

[o narrador olha para câmera (para o narratário) e faz um gesto com a cabeça que sugere que ele faz uma pergunta para o narratário]

\section{TRANSCRIÇÃo DE TRILHAS DESCRITIVAS}

Feita a segmentação da narrativa em unidades entoacionais, passei então a transcrever os dados empregando as trilhas da Tabela 2. Um exemplo da transcrição dessas trilhas aparece na Figura 13 a seguir, que captura um momento da transcrição da narrativa no programa ELAN.

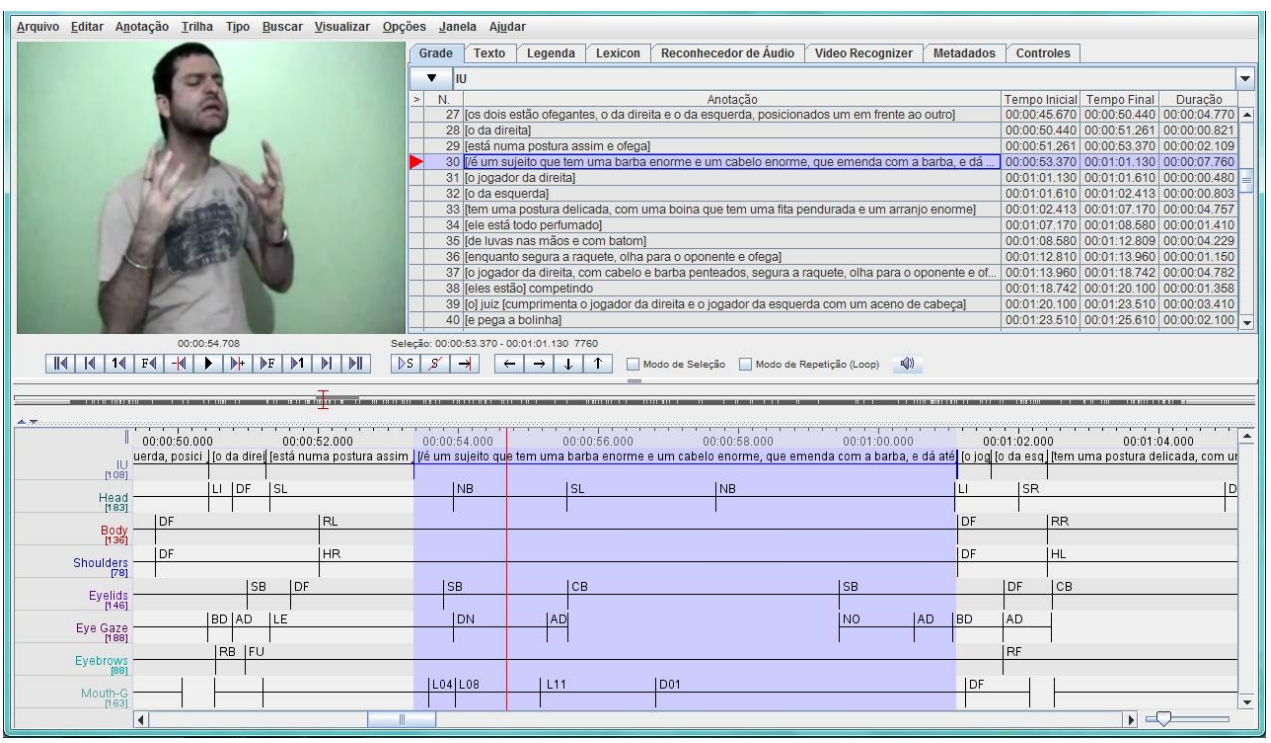

Figura 13 - Exemplo de transcrição

Nesse trecho específico do discurso, que seleciona uma unidade entoacional (parte em azul da transcrição), observam-se as anotações que são feitas para cada parte do corpo. $\mathrm{Na}$ trilha IU, que é a primeira trilha que aparece na figura, está anotada a informação concernente a essa unidade entoacional: [/é um sujeito que tem uma barba enorme e um cabelo enorme, que emenda com a barba, e dá até para pentear a barba/]. Nas trilhas abaixo da IU, foi anotado tudo aquilo que o |narrador| realiza durante esse trecho 
específico do discurso. A linha vertical vermelha na transcrição marca o momento específico do vídeo ilustrado na figura. Se seguirmos a linha, podemos ver as seguintes marcações: na trilha 'Head', está anotado NB, que indica que o sinalizador está com a cabeça inclinada para trás; na trilha 'Body', há a anotação RL, que indica que o sinalizador está com o torso virado para a esquerda; na trilha 'Shoulders', há a anotação HR, que indica que o ombro direito está deslocado pra frente; na trilha 'Eyelids', há a anotação de SB, que indica que o sinalizador está com os olhos semicerrados; na trilha 'Eye Gaze', há a anotação DN, que indica que o sinalizador está com o olhar para baixo; na trilha 'Eyebrows' está anotado FU, que indica que o sinalizador está com as sobrancelhas franzidas; e, finalmente, na trilha 'Mouth-G', está anotado L08, que indica que a configuração bucal muda de lábios contraídos para lábios abertos e novamente contraídos.

Em relação àquilo que é realizado pelas mãos, como foi dito, as anotações foram feitas em trilhas separadas. Nos casos em que a ação manual é um sinal convencional dicionarizado, foi registrada nessa trilha a glosa apresentada no dicionário Capovilla \& Raphael (2001); na trilha ‘Dictionary’ foi incluída a página em que o sinal tem entrada no dicionário. Em casos em que o sinal convencionalizado não tinha entrada no dicionário, foi criada uma glosa para o sinal, e nenhum registro foi feito na trilha 'Dictionary'.

Há outros casos em que se reconhece que o sinalizador está usando as mãos para realizar uma demonstração pictórica de alguma característica perceptível de referente, como no exemplo apresentado na Figura 14 abaixo, em que o sinalizador usa as mãos para realizar a demonstração pictórica da barba do personagem. Nesse caso, descrevo na trilha destinada à descrição dos movimentos manuais a demonstração que está sendo realizada, como apresentado na figura a seguir. A descrição do gesto, anotadas nas trilhas 'HandGdescr-LH' e 'HandG-descr-RH' é a seguinte: 'mãos verticais abertas, palma a palma, dedos separados e curvados próximo às bochechas; mãos descem lentamente até a altura do peito, em um movimento semicircular'. 


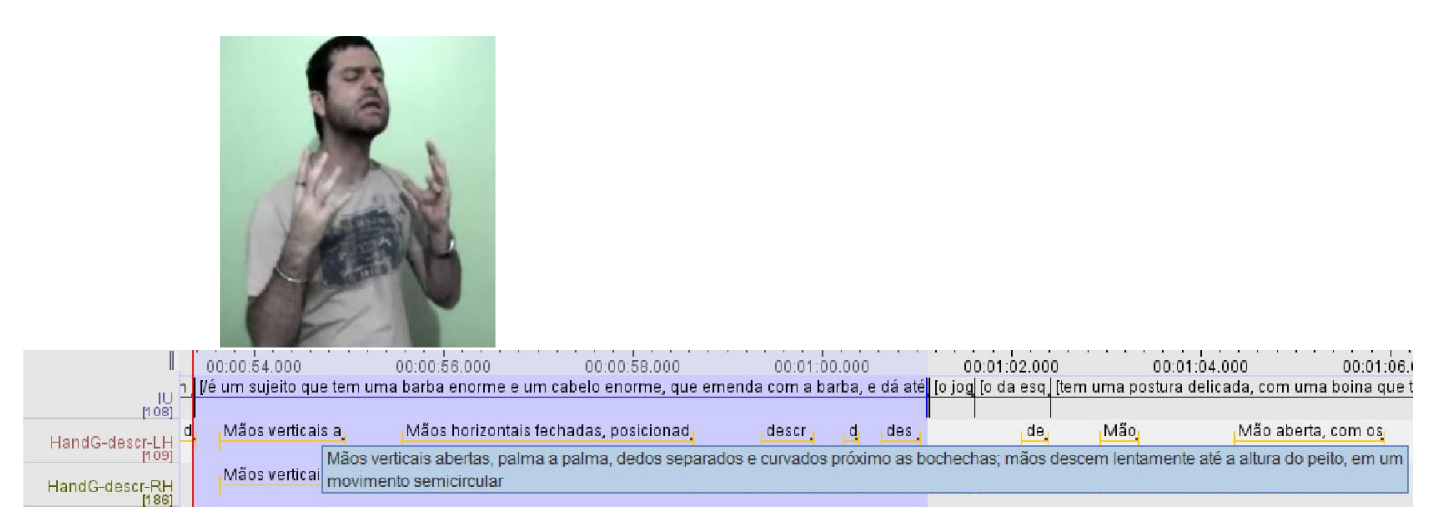

Figura 14 - Anotações nas trilhas de descrição de gestos/sinais manuais

Na narrativa 'Bolinha de Ping Pong', há várias ocorrências de gestos que aparecem recorrentemente ao longo da narrativa: nesses casos, uma descrição objetiva do gesto não convencionalizado é feita na primeira vez, como no exemplo acima; essa descrição é seguida da informação entre colchetes sobre o que aquele gesto representa. Essa informação entre colchetes é, naturalmente, uma interpretação sobre a descrição objetiva, mas vem com o propósito de evitar a repetição de uma descrição muito semelhante à que já havia sido feita anteriormente.

Além desses aspectos visualmente perceptíveis da produção do discurso sinalizado, ainda há o uso de elementos sonoros, que, muitas vezes, acompanha a sinalização, contribuindo com o significado. A observação de que a voz é uns dos instrumentos do corpo usados na realização de demonstrações foi feita por Clark \& Gerrig (1990) e Clark (1996) a respeito de demonstrações em línguas orais. Segundo eles, a voz pode ser usada com entoações variadas, para, dentre outras coisas, i) sinalizar emoções e graus de intensidade e caracterizar vozes de personagens pela mudança de tom; ou ii) para produzir sons que se assemelham aos de alguns eventos sonoros, como no exemplo a seguir, retirado de Clark (1996: 175).

a. So my mom said, “[Whiny voice] You can't go out until you make your bed”.

b. The car engine went [brmbrm] and we were off.

No exemplo em (a), o falante cria, por discurso direto, a demonstração da fala da mãe, que diz, provavelmente ao filho, que ele não sairá enquanto não arrumar a cama. Essa demonstração envolve a mudança no tom de voz, que caracteriza a voz da mãe. No 
exemplo em (b), não há mudança no tom, mas há a produção de um som que se assemelha ao som de um motor de carro em funcionamento. Nesse caso, o uso da voz não está relacionado à produção do enunciado verbal: trata-se de uma demonstração sonora de aspectos sonoros de um evento.

No caso das línguas sinalizadas, em alguns casos, é possível ver os sinalizadores pronunciando, sonoramente, alguma palavra do português, enquanto realizam a sinalização correspondente em libras. Parece ser o que acontece em uma ocorrência da narrativa aqui analisada, em que, enquanto o narrador faz a demonstração da bolinha pedindo ajuda, é possível ouvi-lo dizer, com voz, em português, 'me ajuda', enquanto concomitantemente diz isso em sinais.

O segundo caso, em que o falante usa a voz para imitar um som, também é observado em línguas de sinais. Dudis (2004) afirma que os sinalizadores surdos têm noção de que alguns eventos que eles narram são sonoros, e, ao narrá-los, eles podem realizar um som com a boca que imite aquele som que é produzido no evento (p. 232). $\mathrm{Na}$ narrativa aqui analisada há várias ocorrências de demonstrações desse tipo, em que enquanto o narrador realiza uma demonstração de uma das personagens rebatendo a bolinha de pingue pongue, ele realiza um som que se assemelha ao som de uma batida. Esse mesmo som é produzido todas as vezes que ele demonstra que a bolinha está se chocando contra alguma coisa. Além dos sons vocais, há ainda momentos em que o sinalizador produz sons de assopro para demonstrar o movimento da bolinha no ar.

Para os fins específicos desta pesquisa, também senti necessidade de criar uma trilha descritiva para anotar as ocorrências de sons vocais realizados pelo sinalizador durante a narrativa para demonstrar aspectos sonoros da história. Apesar de não haver uma grande variedade de sons vocais para ser anotada de forma consistente e padronizada, criei uma trilha descritiva chamada 'voice', para registrar, neste momento de modo ainda bastante rudimentar, os sons vocais usados na demonstração. Quanto aos sons bucais, alguns desses sons já fazem parte da anotação da trilha de M-Gesture, apesar de que essa trilha contempla fundamentalmente os aspectos visuais da produção de gestos bucais do sinalizador, mais do que os sonoros.

Para facilitar as análises neste trabalho, criei também trilhas para identificar as ocorrências de demonstrações do corpo, da cabeça, da face, da direção dos olhos, de cada uma das mãos e da voz. Essas trilhas, diferentes das anteriormente, têm o propósito específico de servir como instrumento para análise, permitindo acessar facilmente as 
ocorrências de demonstrações realizadas por cada uma das partes do corpo ao longo da narrativa ou mesmo observar ocorrências de demonstrações realizadas, simultaneamente, por diferentes partes do corpo. Na identificação dessas ocorrências, há casos em que várias partes do corpo convergem para a realização de uma única demonstração - como é o caso das demonstrações da ação dos personagens - e outros, esses mais raros, em que apenas uma parte do corpo realiza a demonstração - como é o caso, algumas vezes, de demonstrações realizadas por gestos manuais icônicos. A figura abaixo apresenta duas ocorrências de demonstração em que o |narrador|, posicionando o corpo à direita, demonstra a ação do |jogador barbudo| e, posicionando o corpo à esquerda, demonstra a ação do |jogador delicado|.

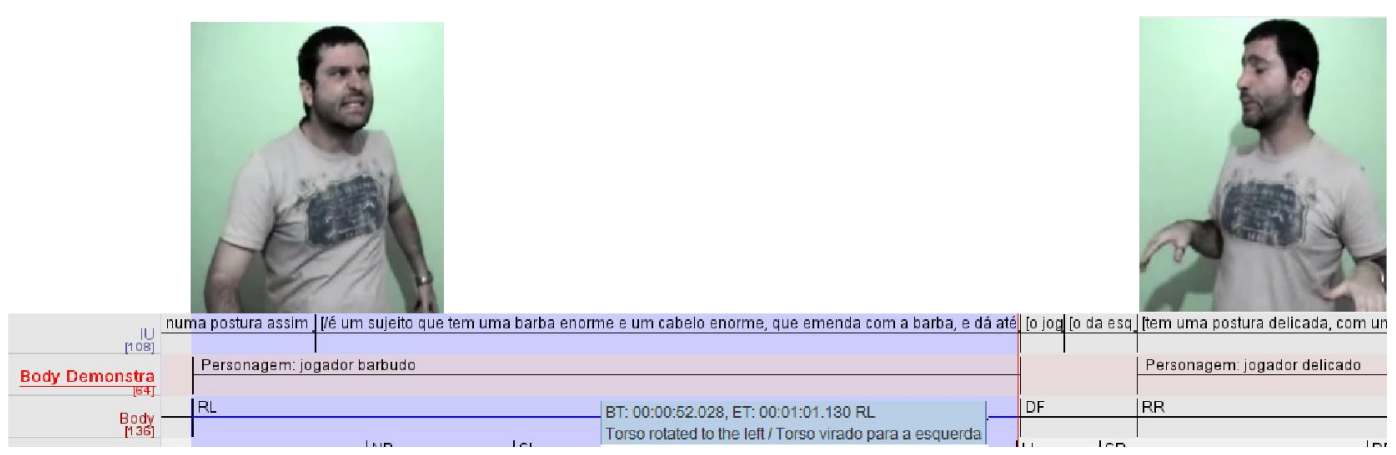

Figura 15 - Anotações nas trilhas de identificação de demonstração feita por mudança na orientação e postura do torso, rosto e expressão facial

No exemplo acima, podemos observar que, enquanto demonstra a orientação e postural corporal da |personagem|, o |narrador| usa outras partes do corpo para caracterizar as |personagens|: o jogador barbudo| está com a sobrancelha franzida, olhando para a direita, com a boca semiaberta, com os dentes à mostra; a cabeça está um pouco inclinada para frente e os braços estão um pouco abertos. Essa demonstração apresenta a expressão facial de raiva do jogador| posicionado à direita, bem como a sua postura corporal, e sua localização à direita no |cenário|. Na sequência, apresentando a postura do ljogador| à esquerda no |cenário|, o |narrador| demonstra também os seus traços delicados: o jogador| está com as sobrancelhas levantadas, com os olhos fechados, com os lábios semifechados e arredondados, e as suas mãos estão abertas, sustentadas à altura do abdômen. Nos dois 
exemplos, a orientação e postura do corpo, seus movimentos e expressões faciais convergem para a realização da demonstração de ação de cada uma das |personagens|.

\subsubsection{APRESENTAÇÃO DOS DADOS}

Por fim, uma terceira parte importante da metodologia de trabalho com dados de língua em perspectiva multimodal é a maneira como esses dados são apresentados durante as análises. Em muitos trabalhos sobre línguas de sinais ou sobre gestos, é comum ver a apresentação de um determinado dado a partir de figuras, com setas indicativas da direção do movimento das mãos; muitas vezes, contudo, não é claro o que exatamente está acontecendo com as mãos. Neste trabalho, de modo semelhante ao que já foi feito em outros trabalhos de análise linguística da libras realizados por membros do grupo pesquisa do laboratório LLIC, busco apresentar os dados da maneira mais detalhada possível, a fim de que aspectos importantes da sinalização possam ser percebidos. ${ }^{42}$ Como nos exemplos anteriormente apresentados, mostro uma sequência de fotos das ocorrências de demonstração acompanhada de glosas para os sinais. Uma vez que a narrativa está disponível no Youtube, incluo em cada exemplo um link para uma janela na internet que apresenta o trecho específico que está sendo analisado. Os links foram criados com o uso do site www.surprise.ly, e levam o leitor para o momento específico do filme que está sendo analisado. Clicando no link indicado na legenda da figura, o leitor, estando em um computador conectado à internet, é levado para a página que exibirá o trecho do filme. Nessa página, o leitor deverá posicionar a seta do mouse na tela e clicar para que o vídeo se inicie.

\subsection{CONSIDERAÇÕES FINAIS}

O objetivo deste capítulo foi discutir os aspectos metodológicos de uma abordagem descritiva multimodal para a análise de uma narrativa sinalizada. Nessa

\footnotetext{
${ }^{42}$ Leite (2008) e Barbosa (2013), membros do grupo de pesquisa, incluíram em seus trabalhos um DVD com o arquivo de mídia e criaram links no corpo do texto que levam o leitor diretamente ao ponto do filme em que se encontra o trecho analisado. No caso do meu trabalho, como a narrativa em questão está publicamente disponível no site do Youtube, optei por direcionar o leitor para o vídeo original, na fonte em que ele foi obtido.
} 
discussão, apresentei a fonte da qual obtive os dados para a pesquisa e os instrumentos usados na transcrição dos dados: o software de transcrição de dados sinalizados em vídeo (ELAN) e o modelo de transcrição, eminentemente descritivo, proposto por McCleary, Viotti \& Leite (2010), com revisões feitas por McCleary (2013) em curso ministrado. Como mostrado ao longo do capítulo, as anotações feitas em trilhas destinadas às partes do corpo do sinalizador buscam descrever movimentos observados durante a sinalização. No entanto, para os fins desta pesquisa, além das trilhas descritivas, foram criadas algumas novas trilhas usadas para o registro de informações decorrentes de análise, como no exemplo apresentado, em que o corpo do sinalizador virado para a esquerda demonstra a posição do |jogador barbudo| e o corpo virado para a direita, a posição do |jogador delicado|. A criação dessas trilhas auxiliou nas análises, pois, além de permitir um acesso rápido às ocorrências de demonstração, permitiu observar simultaneamente, nas diferentes trilhas, as diferentes partes do corpo que participavam da realização de uma ou mais demonstrações.

No próximo capítulo, apresento uma análise das ocorrências de demonstração narrativa 'Bolinha de Ping Pong', observando como elas são realizadas, simultânea e sucessivamente, e como elas contribuem para a estruturação e organização da narrativa. 


\section{DEMONSTRAÇÕES NA NARRATIVA "BOLINHA DE PING PONG"}

\subsection{INTRODUÇÃO}

Quando as pessoas contam histórias em situação de copresença, elas podem fazer uso de diferentes estratégias cognitivas para a elaboração do discurso narrativo: seja em língua oral ou sinalizada, elas podem descrever, indicar e demonstrar os fatos da história, apresentando mais ou menos detalhes, dependendo dos propósitos comunicativos, da disponibilidade receptiva e/ou do esforço exigido pela tarefa (Clark, 1996). Para isso, os contadores precisam, obviamente, conhecer a história, mas isso não é suficiente. A habilidade de contar histórias envolve também ser capaz de se coordenar com o interlocutor no uso das estratégias cognitivas mencionadas. Nas descrições, os interlocutores precisam associar a mesma regra para cada símbolo, isto é, precisam se coordenar de tal modo que eles possam assegurar minimamente que os conceitos que o falante/sinalizador associa aos sinais/gestos convencionais têm, pelo menos, uma intersecção mínima com as associações feitas pelo interlocutor; de outro modo, não seria possível haver comunicação.

Apesar disso, sabemos, muitas vezes, que as palavras dizem menos do que queremos expressar e, nessas situações, buscamos estratégias para nos fazer mais claros. Uma dessas estratégias, seja em discursos orais ou sinalizados, é, como foi discutido anteriormente, o uso de demonstrações, realizadas por meio de diferentes posições ou ações corporais, que envolvem diferentes partes do corpo. Se, durante a contação de uma história em língua oral, o falante disser algo como 'o juiz estava próximo à mesa', o interlocutor terá apenas uma vaga ideia da localização do juiz, não sabendo com exatidão quão próximo ou distante o juiz estava da mesa, nem de que parte da mesa ele estava próximo; quando o falante diz que algo como 'os jogadores estavam tensos', o interlocutor entende o significado da expressão, mas não sabe como os jogadores deixavam transparecer sua tensão. Assim, tanto em língua oral quanto em língua sinalizada, os falantes/sinalizadores podem fazer uso de demonstrações para apresentar aspectos da história que são visualmente perceptíveis para quem a testemunhou. Descrições, indicações e demonstrações formam um todo comunicativo indissociável. 
Nas análises deste capítulo, mostro como o sinalizador apresenta, por meio de demonstrações combinadas com indicações e descrições, os elementos da narrativa e os eventos nela envolvidos.

Se, como sugerem McCleary \& Viotti (2010, 2011, 2014), nas narrativas sinalizadas as demonstrações têm um papel central na organização e estruturação da narrativa, contar histórias nessas línguas envolve um tipo de conhecimento específico, que é o conhecimento das aparências das coisas de que os narradores falam e das ações realizadas pelas personagens. A coordenação de ações dos interlocutores numa contação de história em língua sinalizada requer, então, um envolvimento conjunto na imaginação dos cenários, personagens e ações da narrativa. Como foi dito anteriormente, se, de fato, os sinalizadores preferem demonstrar a descrever muitos dos aspectos das histórias, é necessário que o sinalizador e o seu interlocutor sejam capazes de, não só conhecer o significado convencional de sinais e gestos, mas reconhecer perceptualmente as imagens elaboradas pelas demonstrações. Nesse sentido, a contação de histórias em línguas sinalizadas parece envolver, além do conhecimento de sinais convencionais da língua, um conhecimento corporeado a respeito da aparência das coisas e da ação de corpos em determinadas atividades. Como se verá na análise, a fluência em língua de sinais envolve ser capaz de construir, por meio de demonstrações combinadas com descrições e indicações, a orientação espacial, as diferenças de escala, as mudanças nas posições de visualização na narração dos eventos.

Por essa razão, a narração de eventos específicos pode ser, muitas vezes, difícil de ser feita, se o narrador não sabe como as ações são realizadas ou não tem um conhecimento sobre a aparência daquilo que está sendo demonstrado. Nesse sentido, os narradores precisam ser capazes de organizar conceitualmente o espaço da história e demonstrar a ação das personagens nesse espaço. Por essa mesma razão, há uma diferença substancial entre contar os fatos da narrativa e mostrar esses fatos por meio das demonstrações.

Na narrativa 'Bolinha de Ping Pong', de enredo relativamente simples, o sinalizador conta/mostra como aconteceu um jogo de pingue pongue que, segundo ele, é uma metáfora que pode ser comparada à vida de todos. O enredo da narrativa é o seguinte: no salão em que acontece o campeonato de pingue pongue, há uma arquibancada repleta de pessoas; ao centro, próximo à mesa de pingue pongue, há um juiz; à direita, há um 
jogador com barba e cabelos muito longos, bem penteados; e, à esquerda, há um jogador com expressões delicadas, com um chapéu decorado, com luvas nas mãos, de batom e todo perfumado. Os jogadores se mostram bastante tensos e, posicionados em lados opostos da mesa, trocam olhares, ofegantes. O juiz cumprimenta ambos os jogadores e pega a bolinha para iniciar o jogo. A bolinha é apresentada como uma personagem animada prestativa e disposta a obedecer ao juiz. O juiz entrega a bolinha ao jogador barbudo e pede que ele inicie a partida. O jogador barbudo faz o primeiro lance, mas, para o espanto de todos, o jogador de expressões delicadas segura a bolinha, em vez de rebatêla. O juiz repreende o jogador e diz a ele que reinicie o jogo. O jogador delicado reinicia a partida e o jogo prossegue. Enquanto a bolinha se move continuamente de um lado para o outro, o juiz e a plateia acompanham o seu movimento com o olhar. Num determinado momento do jogo, o juiz e a bolinha começam a trocar olhares enquanto a bolinha continua a se mover pelo espaço, de um lado para o outro. Nesse momento, a bolinha começa a receber as tacadas como se fossem tapas no rosto e, aflita, pede ao juiz que faça o jogo parar. O juiz concorda e, quando a bolinha está passando pela sua frente, pega a bolinha no ar, interrompendo o jogo. O juiz oferece a bolinha ao jogador da esquerda e ao jogador da direita. Em seguida, o narrador olha para frente e acena com a cabeça, como se estivesse pedindo opinião sobre a situação. Nesse momento, a tela escurece - a narrativa acaba.

Essa narrativa, contada aqui com 310 palavras, é contada em libras com apenas 53 sinais convencionalizados, muitos dos quais têm sua iconicidade aproveitada para a realização de demonstrações de aspectos da história. ${ }^{43}$ Como observado por McCleary \& Viotti, nas narrativas sinalizadas, muito pouco é transmitido por meio de sinais: muito daquilo que participa da narração é construído pelas demonstrações que o narrador elabora ao longo da sua contação.

Como McCleary \& Viotti (2014) mostram, nas narrativas face a face é possível perceber alguns dos mesmos níveis de intersubjetividade narrativa que são encontradas em narrativas escritas. A diferença parece ser a de que, como há um autor de carne-e-osso corporalmente presente nessas situações, é preciso levar em consideração também esse nível de intersubjetividade. Diante disso, uma primeira questão que se coloca nas análises desse tipo de narrativa é justamente estabelecer quem está falando/agindo quando a

\footnotetext{
${ }^{43}$ Não incluí nessa soma as letras do alfabeto que o sinalizador usa para soletrar o título em português.
} 
narrativa inicia e durante seu transcorrer: se é o sinalizador de carne-e-osso, um |narrador| ou alguma |personagem|. Como discutido no capítulo anterior, uma vez que o corpo do sinalizador pode ser conceitualmente partido, muitas demonstrações (como também descrições e indicações) podem ocorrer simultameamente, algumas delas pertencentes ao nível do |narrador|, outras ao nível da |personagem|. Uma pergunta, pois, que guia as análises é: como saber a que nível uma ocorrência de demonstração pertence durante a narrativa?

\subsection{Análise da narrativa 'Bolinha de Ping Pong'}

Como foi dito anteriormente, a identificação do nível a que uma determinada ocorrência de demonstração pertence é fundamental na interpretação das ocorrências de demonstração, isto é, para saber quem está realizando uma determinada ação na narrativa e de que tipo é a ação. Para fazer essa distinção, apresento a divisão do filme 'Bolinha de Ping Pong' em partes a seguir.

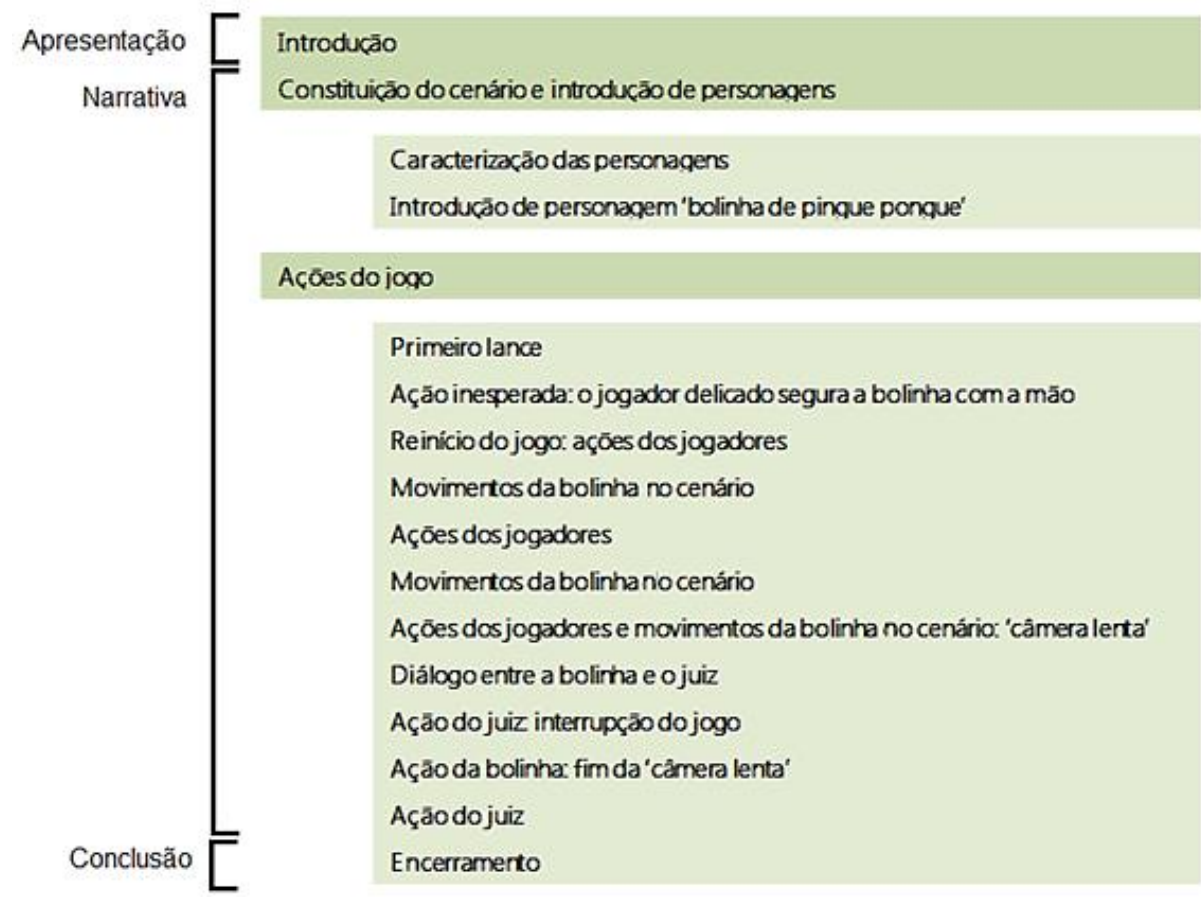

Tabela 4 - Partes da história 
Como ilustrado pelo esquema acima, o vídeo da narrativa 'Bolinha de Ping Pong' se inicia com uma pequena apresentação do sinalizador sobre a narrativa que ele vai contar. Quando a tela do vídeo clareia, o sinalizador já está sinalizando um enunciado, que poderia ser traduzido como: agora eu vou contar uma metáfora muito importante. Depois disso, segue um trecho curto em que o sinalizador soletra, por meio do alfabeto manual da libras, o nome da narrativa em português e, depois, diz o título em libras. Em seguida, ele repete que a história que ele vai contar é uma metáfora incrível, que pode ser comparada à vida de 'todos nós'. Esse trecho se encerra no momento em que o sinalizador diz novamente 'agora eu vou contar' e se prepara para contar a história.

Na parte seguinte, o |narrador| constitui o cenário da história e também introduz as personagens, localizando-as no cenário e apresentando algumas de suas características. Em seguida, há um bloco maior, em que o |narrador| apresenta as ações da narrativa, demonstrando diferentes aspectos perceptíveis dessas ações em cada trecho. A narrativa é encerrada com um aceno no |narrador|, que parece pedir uma opinião sobre a situação.

\section{Introdução: apresentação da narrativa}

$\mathrm{Na}$ apresentação da narrativa, o sinalizador exibe expressões faciais bem marcadas, que variam bastante ao longo do trecho em questão. Como observado por Bavelas \& Chovil (1997) a respeito dos discursos em língua oral, as expressões faciais nas conversas e nas narrativas não são simplesmente expressões emocionais do falante, mas, participando da multimodalidade que caracteriza os discursos face a face, muitas delas são demonstrações, elaboradas para expressar significados relacionados com o conteúdo da fala. As autoras dão evidências de que tanto as expressões faciais exibidas durante a fala quanto os gestos manuais que acompanham o discurso verbal são integrados à fala e desempenham várias funções no discurso.

Dentre as funções que as ações faciais do falante podem assumir, algumas são semânticas (redundantes e não redundantes), e outras, sintáticas (marcadores gramaticais e organizadores da história). As funções semânticas são aquelas que servem para ilustrar aspectos relacionados ao conteúdo da fala; nas funções sintáticas, estão elementos como marcadores gramaticais, marcadores de ênfase, marcadores de questão, marca de continuação da história, dentre outros (Bavelas \& Chovil, 1997: 342). A identificação das 
funções desempenhadas por uma determinada expressão facial num trecho do discurso e seu significado não pode ser feita apenas pela observação de trechos isolados de discurso; Bavelas \& Chovil argumentam que, como acontece com os enunciados verbais, as expressões faciais só têm significado em contexto.

Uma análise minuciosa das expressões faciais exibidas durante o trecho inicial da apresentação da narrativa "Bolinha de Ping Pong" mostra que essa integração entre as expressões faciais e a fala acontece também entre expressões faciais e sinalização em língua sinalizada. Naturalmente, a mudança na expressão facial integrada com a fala é mais bem notada quando observamos um determinado trecho globalmente. A seguir, analiso a mudança na expressão facial e as ocorrências de demonstrações.

No momento em que o vídeo abre e o sinalizador já está sinalizando, apresentado na Figura 16 a seguir, nota-se que a sua expressão facial é bastante séria: com a cabeça um pouco inclinada para a direita e com as sobrancelhas franzidas e os olhos quase fechados, o sinalizador inicia o discurso.

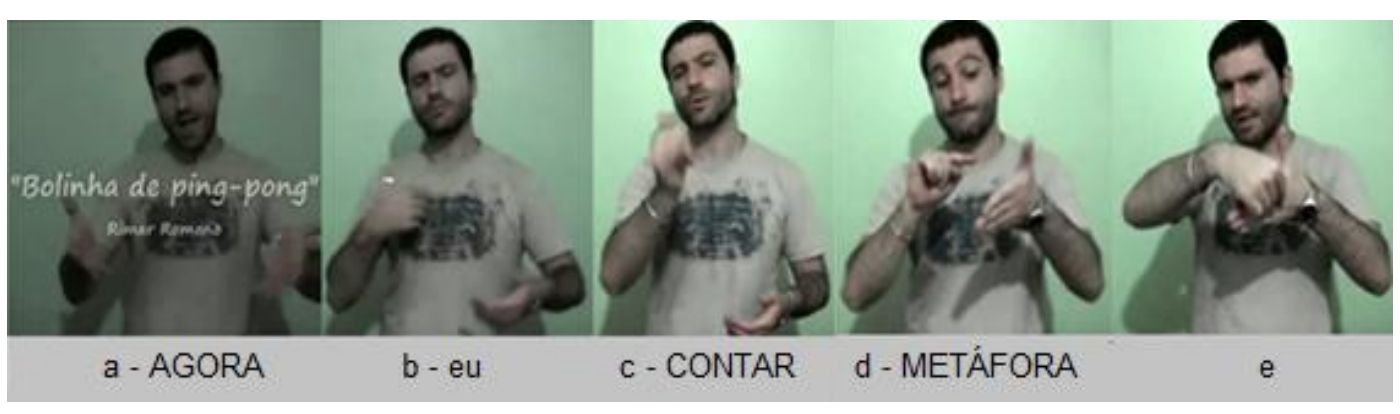

Figura 16 - Início do vídeo ‘Bolinha de Ping Pong' - Trecho 1

No trecho acima, a expressão facial sugere uma certa seriedade com relação àquilo que está sendo dito: como pode ser visto quando se observa esse trecho de introdução à narrativa globalmente, a expressão facial do sinalizador parece sinalizar, como parte do discurso, uma demonstração da sua avaliação a respeito do que está dizendo. Especificamente nesse trecho, a expressão facial pode ser entendida como uma avaliação do sinalizador expressa no discurso, que pode poderia ser traduzida como agora eu vou contar uma metáfora que eu considero muito séria. No quadro (e), a expressão facial do sinalizador, que já vinha bastante tensionada nos quadros entre (a) e (c), se torna ainda mais tensionada depois de o sinalizador, no quadro (d), olhar para a mão passiva durante a realização do sinal METÁFORA. O quadro (f), a seguir, corresponde ao momento final 
da realização do sinal METÁFORA, em que o sinalizador, mantendo a mão esquerda na configuração final do sinal METÁFORA, usa, em seguida, a mão direita para realizar o sinal IMPORTANTE com um movimento mais tensionado, o sinalizador fecha os olhos, deixando os dentes à mostra, e faz uma aceno de cabeça para a direita e para esquerda (como no gesto de 'não'), como pode ser visto assistindo-se ao trecho que corresponde à Figura $17 .{ }^{44}$

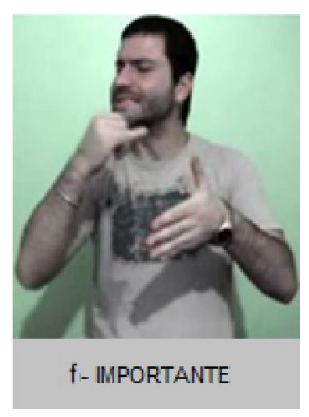

Figura 17 - Expressão facial e movimento manual tensionados simultâneos ao sinal IMPORTANTE - Trecho 2

O fato para o qual chamo a atenção nesse trecho é a integração entre a descrição que inicia esse trecho e os elementos gestuais que a acompanham, bem como a sua importância para a interpretação do que está sendo dito: no trecho da figura acima, enquanto a mão esquerda ainda se mantém sustentada com a configuração final do sinal METÁFORA, a mão direita realiza o sinal IMPORTANTE com um movimento mais tensionado, acompanhado de um movimento de cabeça para o lado direito e uma expressão facial bastante tensionada. Esse conjunto gestual integrado é interpretado localmente como uma intensificação do significado do sinal IMPORTANTE, parte de uma demonstração avaliativa feita pelo sinalizador.

As evidências para sustentar que a expressão facial do sinalizador demonstra sua avaliação sobre o que está sendo dito vêm logo a seguir, quando observamos que o sinalizador, no momento em que apresenta o título da história deixa de exibir uma expressão facial tensionada para, em seguida, voltando a falar da metáfora apresentar novamente uma tensão em sua expressão facial. As figuras a seguir apresentam o

\footnotetext{
${ }^{44}$ Vou tratar dessa manutenção da mão sustentada na configuração final de METÁFORA mais adiante.
} 
momento em que o sinalizador se prepara para apresentar o título da narrativa, que é precedido do enunciado ilustrado pela Figura 18, em que o sinalizador usa os sinais TÍTULO e COMO.

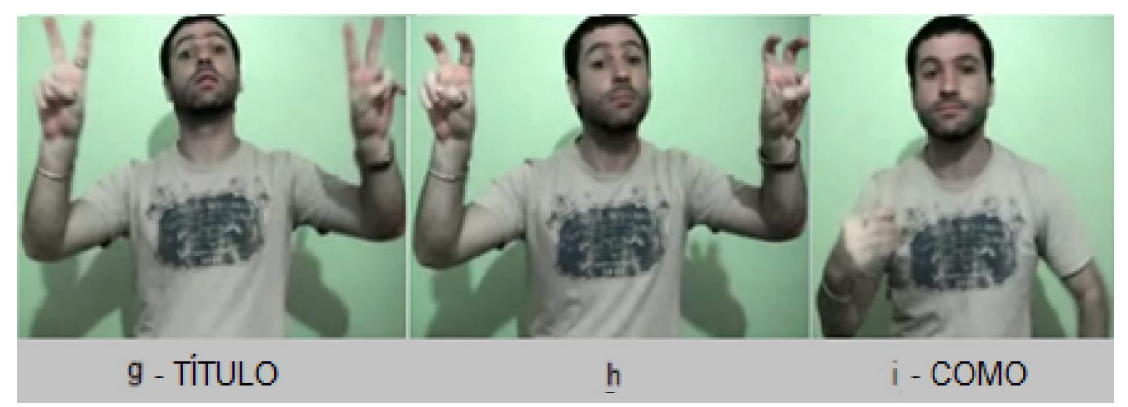

Figura 18 - Expressão facial não tensionada, simultânea à pergunta "Como é o título?" -

Como pode ser observado na figura acima, esses sinais são acompanhados de uma expressão facial e de uma postura corporal diferentes daquelas que o sinalizador mantinha anteriormente: no quadro $(\mathrm{g})$, o sinalizador inclina a cabeça para trás e levanta as sobrancelhas enquanto sinaliza TÍTULO; ${ }^{45}$ durante a realização de TÍTULO, no quadro (h), o sinalizador move o corpo para frente realizando, simultaneamente, um movimento de cabeça como no aceno de 'não'. No quadro (i), o sinalizador realiza o sinal COMO, com o corpo ainda inclinado para frente. Nesse trecho, a expressão facial e a postura corporal do sinalizador são bem diferentes daquelas apresentadas anteriormente: mudando a expressão facial, agora não mais tensionada, o sinalizador faz uma pergunta que introduz o título da narrativa e pode ser traduzida como como é o título?.

Na sequência, o sinalizador soletra, por meio do alfabeto manual da libras, o título da história em português e depois apresenta o título da narrativa em libras. Como é ilustrado pela Figura 19 abaixo, primeiramente, o sinalizador posiciona o corpo ao centro do espaço de sinalização e leva as mãos para a posição de repouso e, com expressão facial neutra, ele usa o sinal PORTUGUÊS para dizer que o título da narrativa que ele vai soletrar está em português.

\footnotetext{
${ }^{45}$ A cabeça inclinada para trás e as sobrancelhas levantadas durante a sinalização de TíTULO são marcas não-manuais que indicam que se trata de uma pergunta equivalente a “Qual é o título?”.
} 


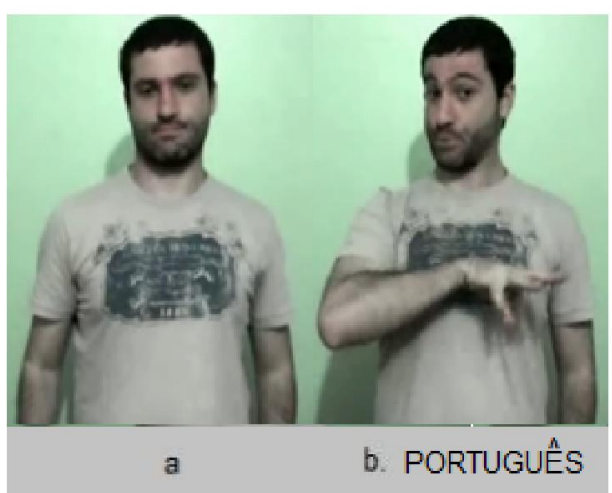

Figura 19 - Expressão facial não tensionada, simultânea à realização do sinal PORTUGUÊS - Trecho 4

Observe-se nas fotos acima, que no momento em que o sinalizador diz que o título da narrativa será apresentado em português sua expressão facial não está tensionada e o seu corpo está posicionado ao centro do espaço de sinalização; na sequência, como ilustram as figuras abaixo, enquanto soletra manualmente, o sinalizador também mantém a expressão facial neutra e o corpo posicionado ao centro do espaço. Durante a soletração, o sinalizador realiza alguns sons vocais simultâneos à soletração manual das letras em libras; a delimitação da fronteira de palavras é feita com um aceno de cabeça simultâneo à realização da última letra de cada palavra e uma pausa curta no final da palavra.

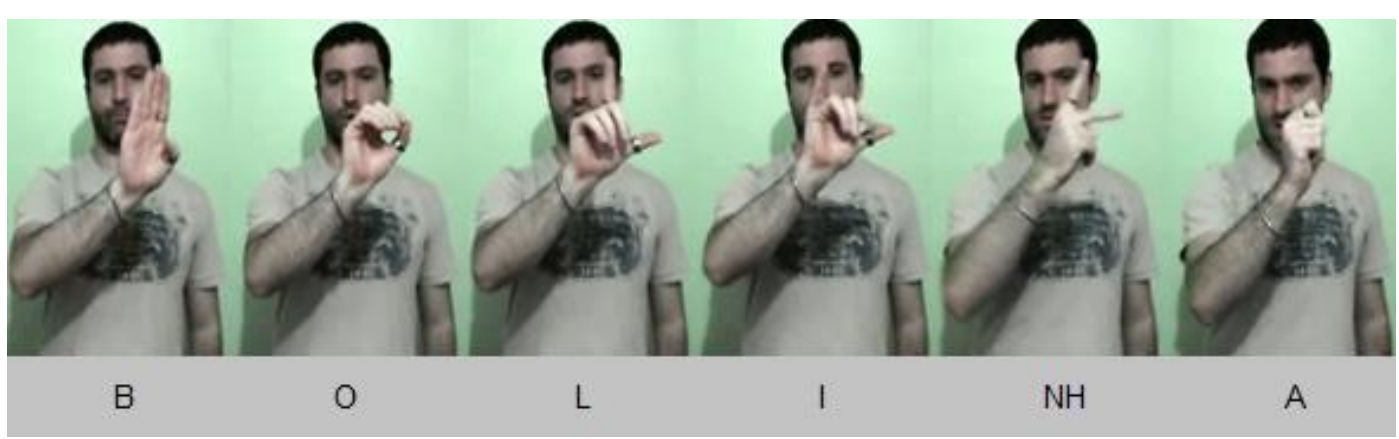



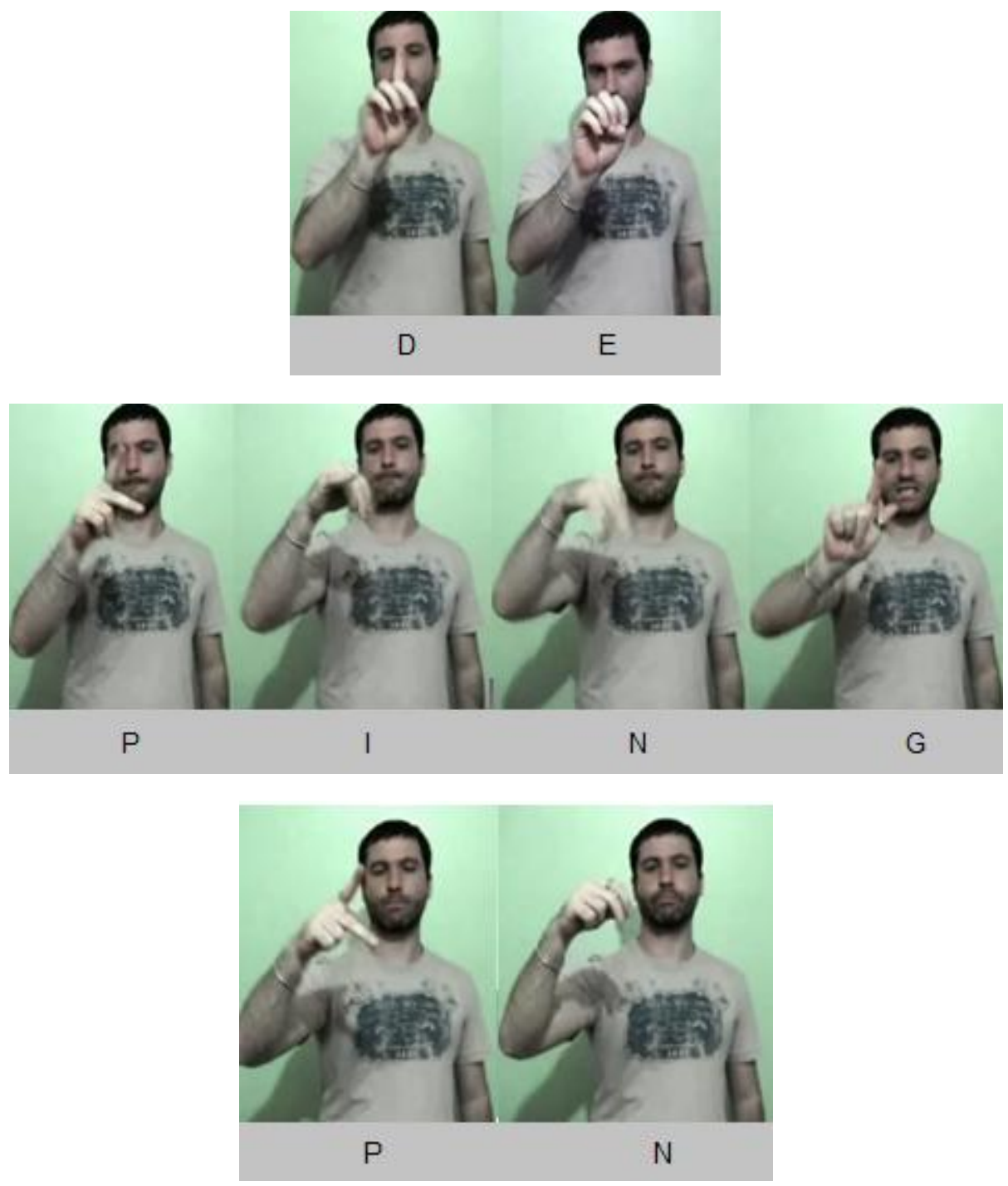

Figura 20 - Expressão facial não tensionada, simultânea à soletração do título em português - Trecho 5

Como ilustra a Figura 21 a seguir, o sinalizador pergunta como (é o título em libras) e apresenta o título da narrativa em libras, logo na sequência. 


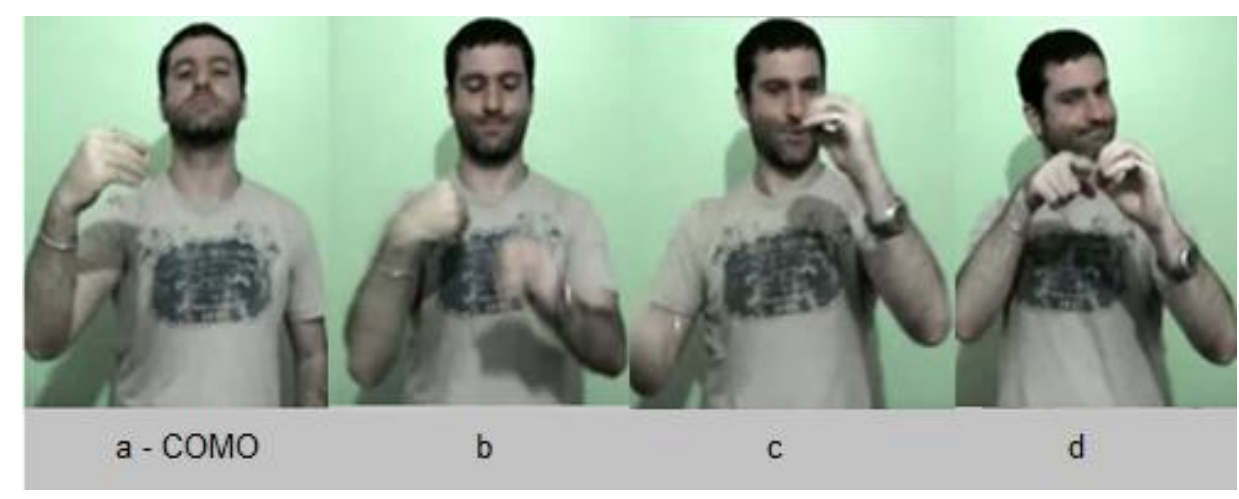

Figura 21 - Apresentação do título da narrativa em libras $-\underline{\text { Trecho } 6}$

No quadro (a), o sinalizador realiza o sinal COMO, inclinando a cabeça para trás e levantando as sobrancelhas; no quadro (b), o sinalizador, enquanto olha para as mãos, realiza um sinal/gesto icônico que se assemelha a uma raquete batendo numa bolinha de pingue pongue e, simultaneamente, emite um som vocal. ${ }^{46}$ Esse sinal/gesto não convencional é usado para descrever o tipo de bolinha referido no título: é uma bolinha de pingue pongue. ${ }^{47} \mathrm{Em}$ seguida, no quadro (c), o sinalizador realiza o gesto de 'bolinha' e ainda produz um som vocal simultaneamente, que se assemelha à pronúncia de uma parte da palavra 'bola', em português 'bó'. O gesto de bolinha, ilustrado no quadro (c) acima, é realizado com uma configuração da mão esquerda. No quadro (d), o sinalizador, mantendo a mão esquerda sustentada na configuração do gesto de 'bolinha', se refere à |bolinha| apontando para ela com a mão direita. ${ }^{48}$

Como pode ser visto a partir do quadro (b) acima, no momento em que o sinalizador começa a apresentar o título da narrativa em sinais/gestos, ele esboça um sorriso, com o canto dos lábios; no quadro (d), o sinalizador vira a cabeça para a esquerda

\footnotetext{
${ }^{46}$ Não é claro se se o som vocal simultâneo ao sinal se trata da pronúncia vocal da palavra 'pingue pongue' ou se é uma imitação do som de uma raquete se chocando contra uma bolinha; como a própria palavra 'pingue pongue' em português é uma onomatopeia, essa distinção parece não ser muito relevante.

${ }^{47}$ Embora esse sinal/gesto não seja convencionalizado, seguido da apresentação do título em português, ele é facilmente reconhecido como correspondendo a 'pingue pongue'. Uma vez que esse sinal/gesto é usado para descrever o tipo de bolinha e, na ocorrência mais adiante, o tipo de jogo de campeonato, anoto a próxima ocorrência como sendo um sinal, mas estou consciente do status nebuloso dessa classificação.

${ }^{48}$ Trato dessa manutenção da mão sustentada na realização do gesto de 'bolinha' ao final da discussão deste bloco.
} 
e aperta os lábios, ainda esboçando um sorriso. Embora não seja claro por que o sinalizador está sorrindo, a análise aqui é a de que essa expressão facial nesse trecho também demonstra a avaliação do sinalizador, ou mesmo uma posição dele, a respeito daquilo que está sinalizando, que pode ser um sentimento positivo em relação à sua história ou alguma outra avaliação, até neste momento, não explicitada.

No momento seguinte, o sinalizador começa a dizer que a metáfora, cujo título foi anunciado, é incrível, como ilustra a Figura 22 a seguir.

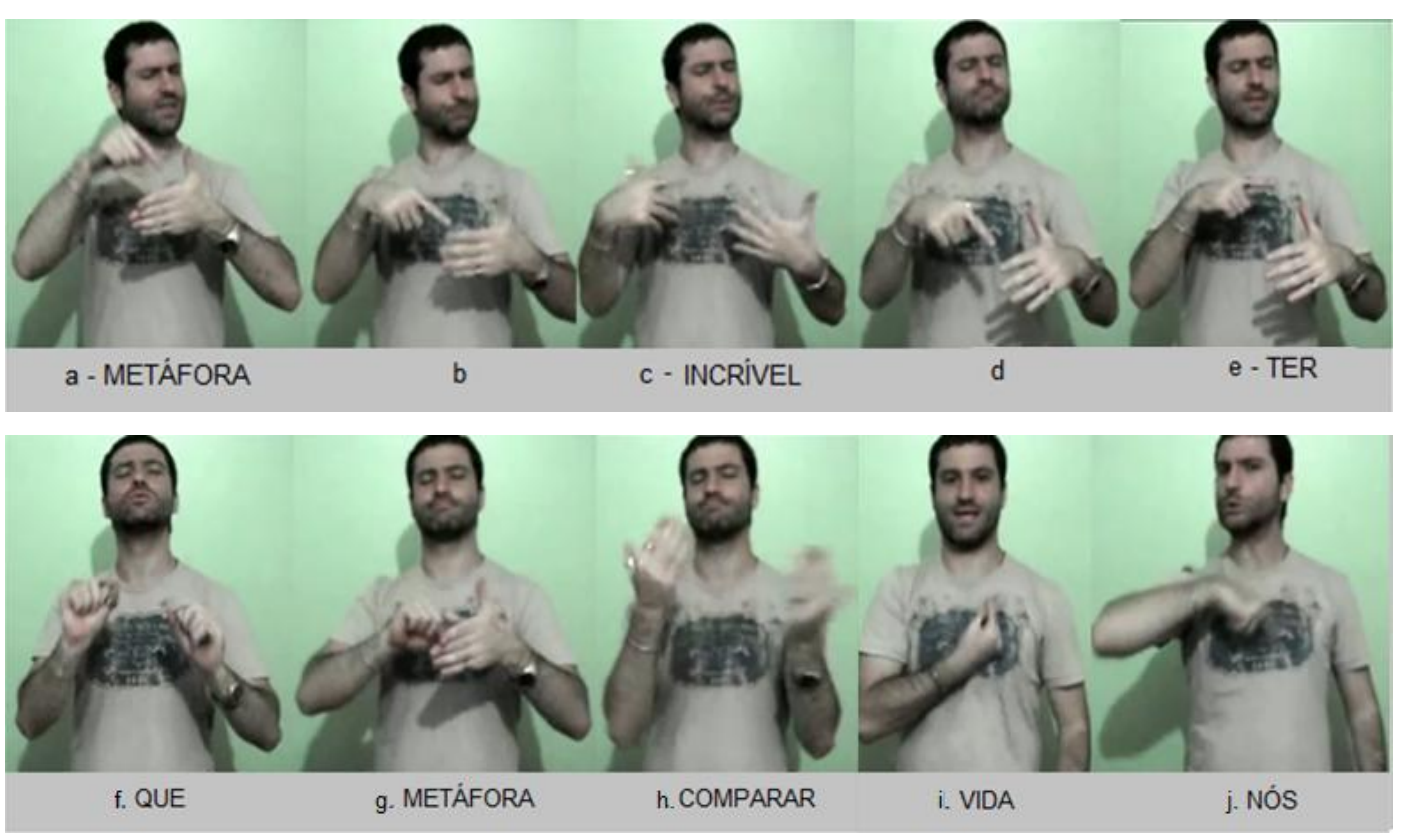

Figura 22 - Expressão facial não tensionada, simultânea ao momento em que o sinalizador volta a falar da metáfora - $\underline{\text { Trecho } 7}$

Mantendo os olhos fechados e as sobrancelhas franzidas, o sinalizador sinaliza um enunciado ( $\mathrm{a}-\mathrm{f})$ que pode ser traduzido como 'esta metáfora, o que ela tem de incrível?' Continuando com os olhos fechados (quadros (g) e (h)) e abrindo-os em seguida (quadros (i) e (j)), o sinalizador diz que 'a metáfora (é uma) comparação com a vida de todos nós'. Observe-se que, embora em (i) a expressão facial pareça não estar tensionada, esse relaxamento da face dura somente um instante e, no quadro (j), a expressão facial já começa a se mostrar tensionada novamente.

Essa sequência de expressões faciais tensionadas nos dois momentos em que fala sobre a metáfora, isto é, no início e, logo depois da apresentação do título, serve como 
evidência para a afirmação de que a expressão facial tensionada é uma avaliação do sinalizador a respeito da metáfora. ${ }^{49}$ Como pode ser percebido assistindo-se ao trecho ilustrado pela figura acima, no momento correspondente ao quadro (a), o sinalizador produz vocalmente um som que se assemelha à pronúncia da palavra 'metáfora' em português e, em seguida, no momento correspondente ao quadro (b), ele realiza um assopro simultâneo à realização do sinal INCRÍVEL, que é claramente ouvido na gravação; esse assopro, simultâneo ao sinal INCRÍVEL, contribui com o significado do sinal, intensificando-o.

Esse trecho se encerra no momento em que o sinalizador volta ambas as mãos para a posição de repouso e, faz dois acenos de cabeça seguidos, ambos acompanhados de expressões faciais bem marcadas, como ilustra a Figura 23 a seguir.

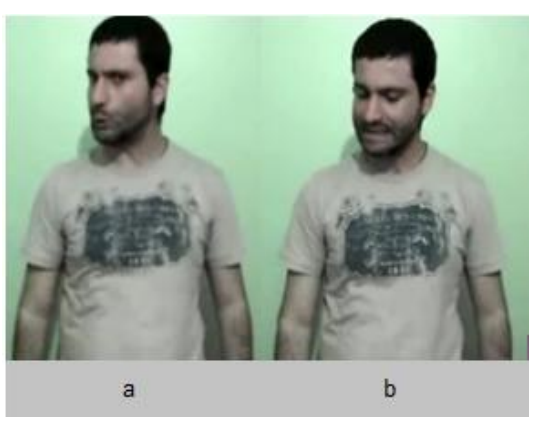

Figura 23 - Demonstração de seriedade/perplexidade e preparação para o início da narrativa - $\underline{\text { Trecho } 8}$

No quadro (a), o sinalizador exibe uma expressão facial de seriedade e perplexidade: com as sobrancelhas franzidas, o rosto virado para a direita enquanto mantém contato visual com o interlocutor, ele faz um aceno de cabeça movendo a cabeça para baixo e, com os lábios arredondados, bufa. ${ }^{50}$ Nesse momento, a expressão facial do sinalizador, acompanhada desse assopro forte, ao mesmo tempo que demonstra a sua perplexidade, pode ser entendida como uma demonstração de uma maneira de aliviar a tensão antes de começar uma tarefa difícil. Em seguida, no quadro (b), movendo a cabeça

\footnotetext{
${ }^{49}$ Como as avaliações que as pessoas fazem sobre as coisas podem ser manifestas tanto em expressões naturais quanto em 'demonstrações', não pretendo fazer aqui uma distinção entre uma coisa e outra; antes, tratando a demonstração como uma estratégia discursiva, mostro a integração entre a descrição e a expressão facial de avaliação, que, acompanhando a fala, dá evidência de ser uma demonstração do sinalizador a respeito do que está falando, claramente coordenada com o conteúdo da fala.

${ }^{50} \mathrm{O}$ som produzido é fortemente ouvido na gravação.
} 
para a esquerda e fazendo um segundo aceno de cabeça para baixo, o sinalizador olha para baixo e deixa os lábios bem abertos, com os dentes à mostra; o aceno de cabeça parece revelar que o sinalizador, finalmente, se decide a iniciar a tarefa e pensa por um instante sobre a melhor maneira de iniciar a narração.

Em suma, a análise das sequências de expressões faciais exibidas nesse trecho da apresentação dá evidências de que as expressões faciais do sinalizador são bem coordenadas com aquilo que está sendo expresso verbalmente; ela mostra, ainda, que algumas dessas expressões elaboram um tipo de demonstração, que representa a avaliação e/ou as impressões do sinalizador a respeito do que está dizendo: no trecho inicial, o sinalizador mostrava uma expressão facial séria, tensionada, enquanto falava da metáfora; a expressão facial se torna neutra no momento em que o sinalizador soletra; depois disso, ao anunciar o título da narrativa em sinais/gestos o narrador sorri; voltando a falar da metáfora, a sua expressão facial é novamente séria e tensionada e, finalmente, como mostra a Figura 24 a seguir, dos quadros de (a) até (e), ao anunciar o início da narrativa, o sinalizador sorri.

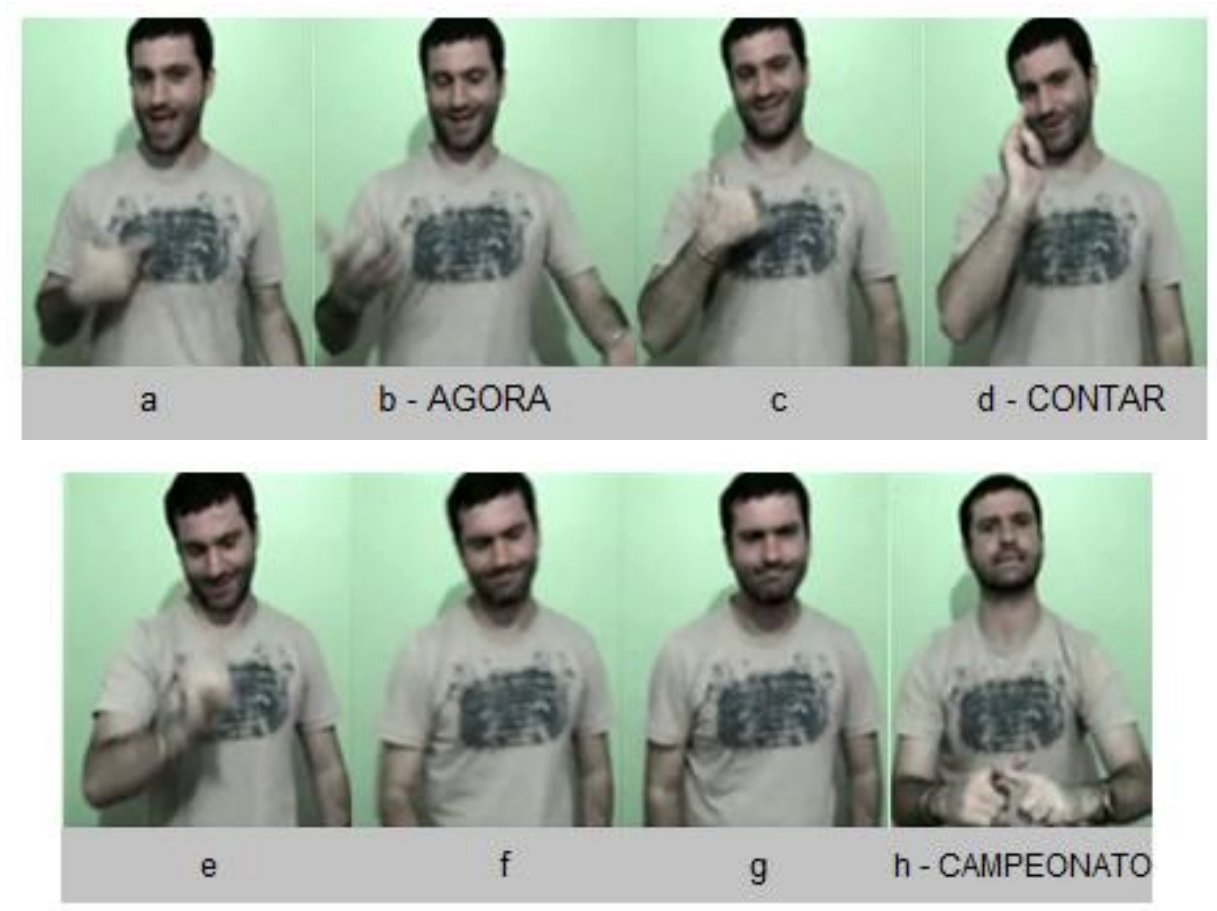

Figura 24 - Anúncio de início da narrativa - $\underline{\text { Trecho } 9}$ 
A partir do quadro (f), a expressão facial do sinalizador se modifica novamente: é nesse momento que o sinalizador se prepara para contar a história. A mudança de postura corporal e de expressão facial nesse trecho marca, como foi discutido no capítulo 2, a passagem para o nível do |narrador|: a partir daí, o sinalizador dá voz a um |narrador| ficcional, que conta a história. Como pôde ser visto no primeiro bloco, correspondente à apresentação, não há pistas que nos permitam inferir que quem está falando é alguém que não o próprio sinalizador. Assim, entendemos que as ações desempenhadas nesse trecho da elaboração do discurso (as expressões faciais, posturas corporais e sinais/gestos manuais) são do próprio sinalizador, que apresenta a história e assume uma posição a respeito dela, expressando sua avaliação por meio de marcas manuais (o uso do sinal IMPORTANTE com um movimento mais tensionado e do sinal INCRÍVEL) e não manuais (expressões faciais que denotam seriedade e preocupação sobre o próprio evento de contar a história, e o assopro simultâneo à realização de INCRÍVEL, que intensifica o significado do sinal manual). Na passagem para o nível do |narrador|, entramos para um novo domínio de ação: as ações desempenhadas a partir desse momento são entendidas como sendo do |narrador|, até o momento em que houver pista de que novos domínios de ação estão sendo elaborados. Observe-se ainda na Figura 24 que, na passagem para o domínio do |narrador|, o sinalizador passa de um sorriso para uma expressão séria; essa expressão deve ser entendida como uma avaliação, desta vez do |narrador|, a respeito do que ele vai começar a contar na sequência: o campeonato de pingue pongue.

Antes de apresentar o próximo bloco, discuto ainda outro tipo de demonstração observado no bloco inicial de apresentação, que é aquele que é realizado pelo uso de boias (Liddell, 2003; Dudis, 2011). De acordo com Liddell, as boias são fruto da integração conceitual entre entidades conceituais do discurso e a mão passiva sustentada em uma determinada configuração enquanto a mão ativa continua produzindo sinais (2003: 223). Uma vez realizadas, as boias se tornam instâncias visíveis da entidade conceitual que a mão passiva representa, e servem para fazer referência a essas entidades. Existem diferentes tipos de boias, sendo que elas variam em grau de concretude/abstração: as boias depictivas, que representam aspectos visualmente perceptíveis de entidades concretas (2003: 263); as boias listas, por meio das quais o sinalizador cria uma lista visível com os dedos da mão passiva, que, por sua vez, são relacionados, no discurso a certas entidades - o sinalizador pode apontar para os dedos ou tocá-los para fazer referência às entidades 
a eles associadas (2003: 223); e, ainda, um tipo mais abstrato, que Liddell denomina boia fragmento, que consiste em manter a mão passiva configurada como na realização final de um sinal/gesto empregado, criando uma instância visível do sinal, cujo conceito poderá ser acessado em futuras referências (2003: 248).

Dos tipos de boia apresentados por Liddell, considerados por Dudis como tipos de demonstração (para Dudis, tipos de depiction), identifico, no bloco inicial, dois: a boia depictiva (quadro (b)) e a boia fragmento (quadros (c), (e), (g), (h)), como ilustra a Figura 25 a seguir.
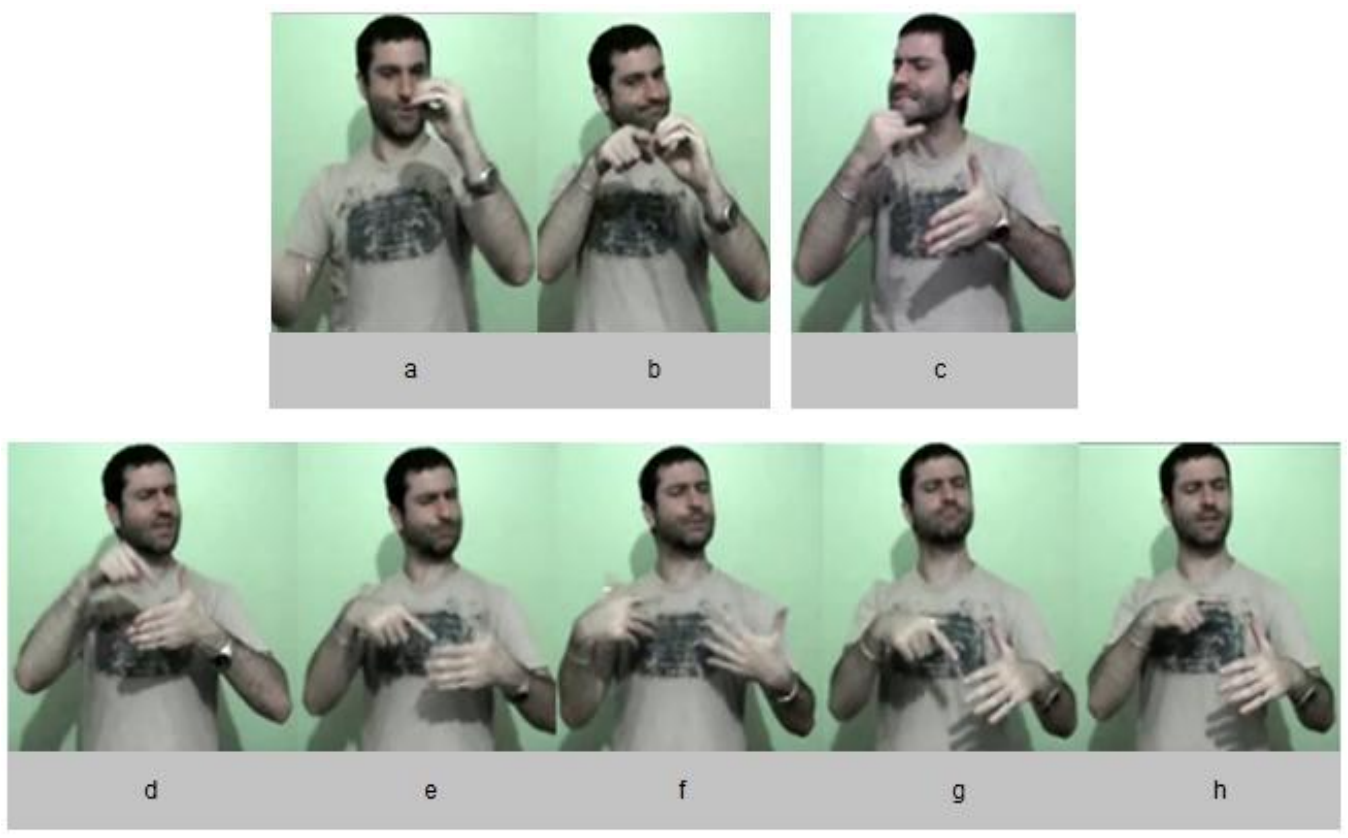

Figura 25 - Demonstrações elaboradas por boias

No quadro (a) acima, já analisado anteriormente, o sinalizador realiza o gesto de 'bolinha' no momento em que apresenta o título da narrativa em libras. Depois de realizar esse gesto com a mão esquerda, o sinalizador mantém a mão esquerda sustentada na configuração final do gesto de 'bolinha' e, com a mão direita, aponta para a mão esquerda para se referir à |bolinha|. Uma vez que a mão esquerda se mantém sustentada durante a realização do apontamento, que segue imediatamente a realização do gesto de 'bolinha', a configuração de mão final do gesto de 'bolinha' é entendida como sendo uma boia, que 
serve para referências futuras. ${ }^{51}$ Essa boia é considerada depictiva por causa da sua iconicidade: o formato da mão se assemelha ao formato de uma 'bolinha' e a boia demonstra, portanto, aspectos visualmente perceptíveis do referente. No caso apresentado em (c), um processo semelhante acontece, mas agora trata-se de uma boia fragmento: depois de realizar o sinal METÁFORA (não ilustrado na figura), o sinalizador mantém, no quadro (c), a mão esquerda com a configuração final do sinal METÁFORA - mão vertical aberta, dedos unidos, palma para a direita, localizado à altura do peito - e realiza, simultaneamente, o sinal IMPORTANTE com a mão direita, para significar que a |metáfora| é importante. Note-se que, neste caso, embora a configuração de mão na boia que significa |metáfora| não faça demonstração de nenhum aspecto perceptível do referente, a mão se torna uma instância visível daquele conceito enquanto a mão está sustentada; por isso, Liddell chama essa boia de fragmento, porque um fragmento de sinal é aproveitado para criar uma instância visível do conceito expresso pelo sinal. Uma vez que essa boia não demonstra aspectos perceptíveis do referente, estou considerando que se trata de um tipo mais abstrato de demonstração. ${ }^{52}$

Semelhante ao que acontece no quadro (c), nas demais ocorrências de boia fragmento ilustradas pela figura acima, o sinalizador, depois de realizar o sinal manual, mantém a mão com a configuração final do sinal e aponta para essa mão, sustentada no espaço: no quadro (d), o sinalizador realiza o sinal METÁFORA e, no quadro (e), mantendo a mão esquerda sustentada na configuração final do sinal, aponta com a mão direita para a boia; semelhantemente, no quadro (f), o sinalizador realiza INCRÍVEL e mantendo a mão esquerda na configuração final do sinal, aponta para a boia com a mão direita; no quadro (h), ainda com a mão configurada como na realização final do sinal INCRÍVEL, o sinalizador realiza com a mão direita o sinal TER. Esses tipos de demonstração são bastante abstratos e, embora não façam referência a aspectos visualmente perceptível do referente, se tornam instâncias visíveis de conceitos e contribuem para a organização do discurso e para o processo de referenciação.

\footnotetext{
51 Uma questão pouco explorada pela literatura é qual é a função desse apontamento logo na sequência. Esse é um tópico para futuras pesquisas.

52 É comum a ocorrência de boias fragmento seguidas de adjetivos, como no exemplo sob análise. Mais pesquisas são necessárias para entender a função desse recurso.
} 


\section{Constituição do cenário e introdução de personagens}

Como é comum acontecer em algumas narrativas, na 'Bolinha de Ping Pong', o |narrador| inicia a contação da história, apresentando o cenário e os elementos que participam dele. Primeiramente, como mostra a Figura 26, ele realiza os sinais CAMPEONATO e PINGUE-PONGUE, que descrevem o evento da história.

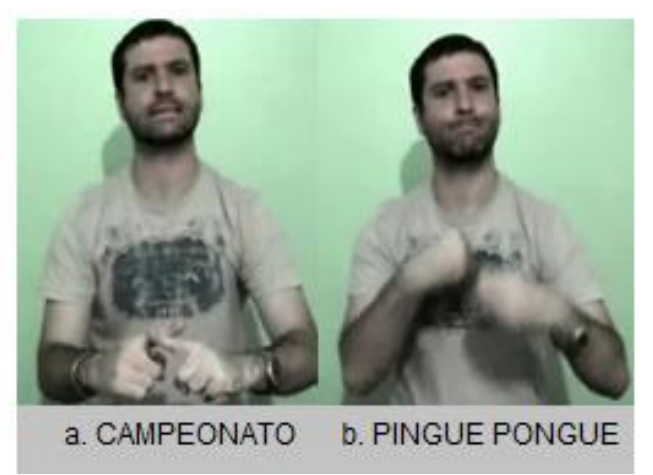

Figura 26 - Expressão facial sério no início da narrativa - $\underline{\text { Trecho } 10}$

Simultaneamente à realização de CAMPEONATO, o |narrador| franze parcialmente as sobrancelhas e afasta os lábios; e simultaneamente à realização de PINGUE-PONGUE, ele produz um som que se assemelha à pronúncia da palavra 'pingue pongue' ou, ainda, ao som de uma bolinha batendo na raquete. Como pode ser observado na figura acima, no momento em que o |narrador| descreve o evento, ele apresenta uma expressão facial séria, que pode ser interpretada como uma demonstração de sua avaliação a respeito do evento que ele vai contar.

Depois disso, o |narrador| já começa a apresentar os elementos que participam do cenário do evento, organizando o $\quad$ cenário| da história. Usando o sinal ARQUIBANCADA realizado com um movimento não prototípico, como pode ser visto na Figura 27 a seguir, o |narrador| apresenta o primeiro elemento do |cenário|: uma |arquibancada| tão grande que ocupa toda a região em frente ao corpo do |narrador|. O espaço usado para a realização do sinal passa a ser interpretado como o |espaço do evento| (i.e. o |cenário| da história). 


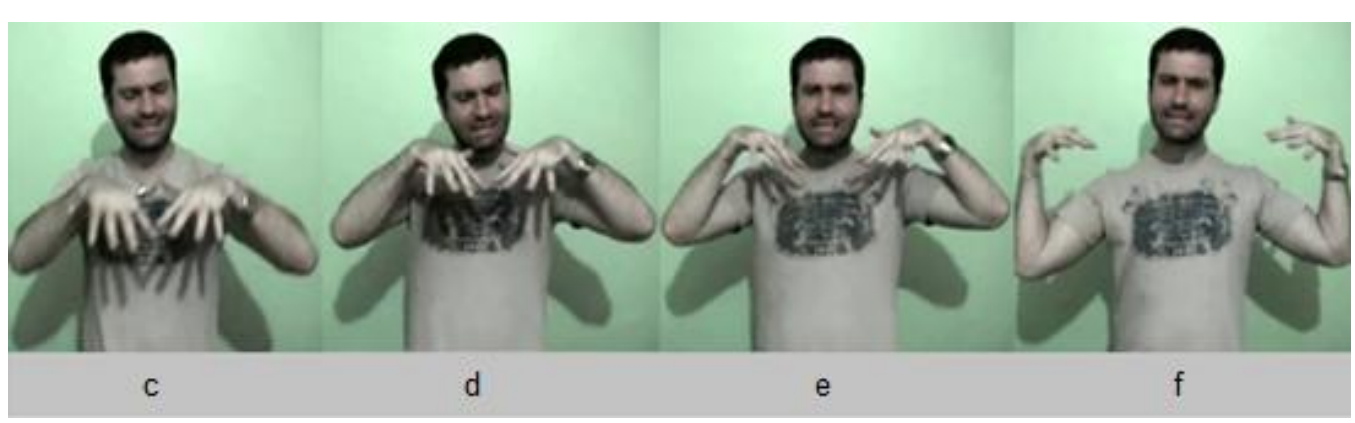

Figura 27 - Localização da |arquibancada | no |cenário| da história - $\underline{\text { Trecho } 11}$

É por meio da observação dos elementos simultâneos à realização do sinal ARQUIBANCADA que se sabe que o |narrador| não está simplesmente usando o sinal para fazer referência a uma arquibancada qualquer, mas que está realizando o sinal de maneira a construir o |cenário| da história, posicionando a |arquibancada| nesse |cenário|. Nos quadros (c) e (d) da Figura 27, ao início da realização do sinal, o |narrador| olha para a região onde as mãos estão posicionadas. Como previamente discutido no capítulo 2, na construção de |cenário| nos discursos multimodais, o posicionamento das mãos, a sua orientação e a direção do olhar servem como pistas importantes para reconhecer a organização de um |cenário| no espaço. Na figura acima, observamos que, além do direcionamento do olhar para baixo, o sinal ARQUIBANCADA é realizado com um movimento não prototípico. Prototipicamente, o sinal de ARQUIBANCADA é realizado com as mãos abertas, palmas para baixo, dedos separados apontando para baixo, posicionadas à altura do peito, com um movimento curto das mãos para cima até a posição em que estão as mãos do sinalizador no quadro (d) acima.

Na narrativa, o sinal ARQUIBANCADA é realizado de maneira significativa: o narrador levanta as mãos até próximo aos ombros e faz um movimento semicircular, afastando-as dos ombros e movendo-as para frente, como pode ser observado na Figura 27. Realizando o sinal com esse movimento alongado e alargado, o |narrador| não só demonstra a localização da |arquibancada| no |cenário| que está construindo diante de si, como também demonstra o seu formato e a sua extensão. A expansão do movimento do sinal e a sua localização à altura dos ombros expressam o significado de que a |arquibancada| é tão grande que circunda todo o |cenário| construído em frente ao corpo do sinalizador. Nesse momento da narrativa, o |narrador| ainda não introduziu nenhuma 
personagem; por isso, podemos entender que a expressão facial tensionada, sugerindo que a |arquibancada| é muito grande, é do próprio |narrador|. Além disso, o |narrador|, simultaneamente à realização do sinal, inclina as costas um pouco para trás, o que não só reforça o tamanho, como também sugere uma possível inclinação da |arquibancada|.

Embora o sinal seja realizado de maneira bastante expandida, chegando à altura dos ombros, o |narrador| não está incluído no |cenário|: o olhar do |narrador| voltado para baixo nos quadros (c) e (d) da Figura 27 serve como evidência de que o |narrador| olha para o |cenário| de cima, de uma posição externa e superior. ${ }^{53}$ Depois de localizar a |arquibancada|, o |narrador| continua apresentando o |cenário| e introduzindo outros elementos: a |mesa de pingue pongue|, a |plateia|, o |juiz|, os |jogadores| e a |bolinha de pingue pongue|. Como dito no capítulo 2, o posicionamento e orientação específicos das mãos na realização dos sinais/gestos usados na constituição do |cenário|, acompanhados do direcionamento do olhar, são elementos que nos permitem inferir a posição de visualização| do |narrador| diante da cena ficcional da história.

Para entender isso, observemos a Figura 28 a seguir, retirada de um trecho de vídeo de uma partida de pingue pongue, disponibilizado no Youtube. ${ }^{54}$

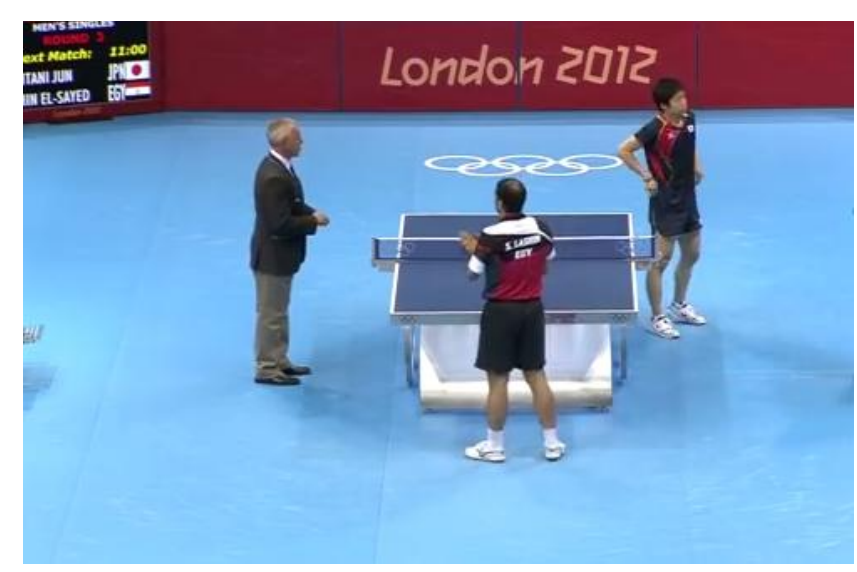

Figura 28 - Salão de jogo de pingue pongue, visto de cima

\footnotetext{
53 Se, na construção do |cenário|, o |narrador| tivesse uma |posição de visualização| interna ao |cenário|, durante a realização do sinal, direcionaria o olhar para cima, como se estivesse olhando para o |cenário| ao seu redor, e não para baixo.

54 A imagem a seguir foi retirada de vídeo assistido no Youtube pelo link: https://www.youtube.com/watch?v=rQ1rMsWXT88, de uma partida entre os jogadores Jun Mizutani e El-Sayed Lashin, nos jogos Olímpicos de Londres, em 2012. A imagem do vídeo corresponde ao momento 2:43 da gravação.
} 
Nessa figura, o salão de jogos é visto de uma posição superior, à direita do juiz, que, na foto, está entre os dois jogadores; essa mesma cena teria uma organização espacial diferente se a câmera estivesse posicionada em outro lugar, pegando outra perspectiva da cena. As figuras a seguir ilustram como a mesma cena seria vista de posições de visualização diferentes:
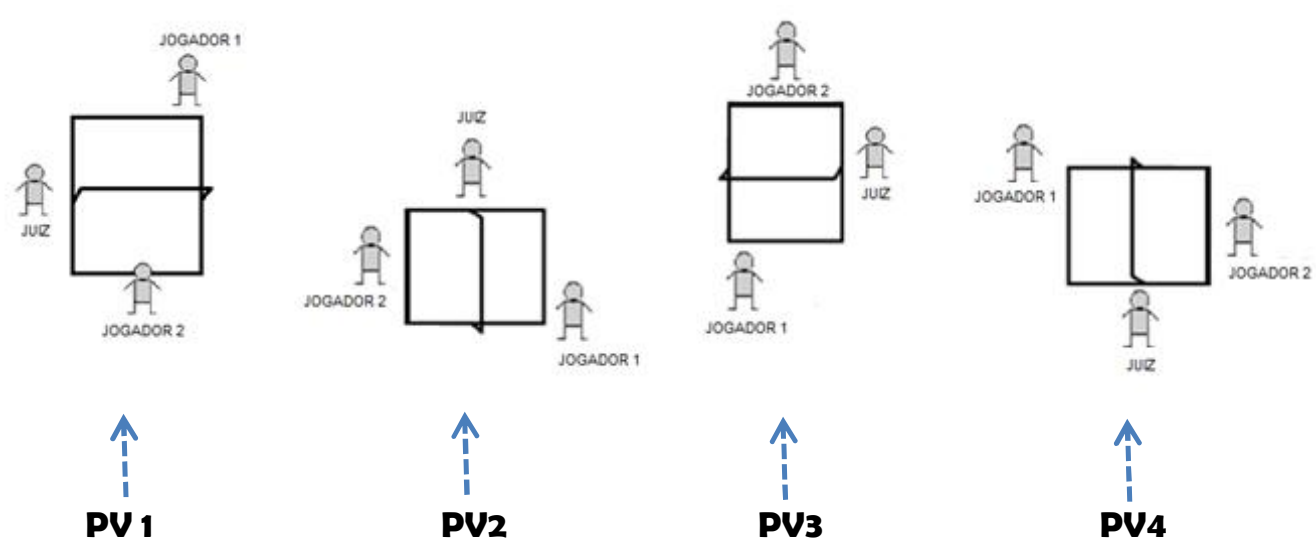

Figura 29 - Diferentes posições de visualização da mesma cena

Para organizar espacialmente o |cenário|, o |narrador| precisa assumir uma posição em relação a ele. Tomando como referência a localização da |arquibancada| no |cenário|, o |narrador| localiza a |mesa de pingue pongue| ao centro do espaço de sinalização e, em seguida, localiza as |personagens| da história, nas cabeceiras da |mesa de pingue pongue|. Os gestos empregados pelo |narrador|, apresentados na Figura 30, desenham o formato da |mesa de pingue pongue| a partir da |posição de visualização| escolhida pelo |narrador|.

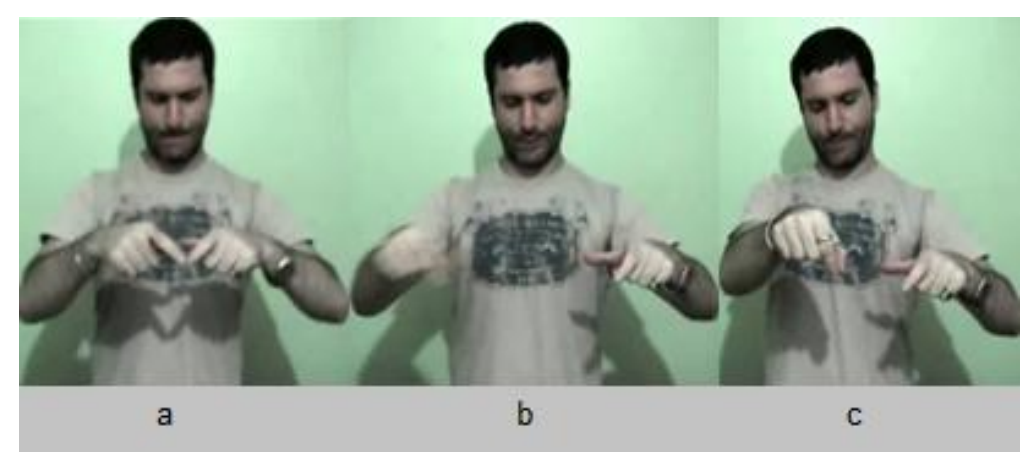

Figura 30 - Localização da |mesa | no |cenário| da história - Trecho 12 
Como ilustrado na figura, nos quadros (a) e (b), o |narrador|, olhando para a região à frente do corpo, posiciona as mãos diante do corpo, formando um desenho quadrangular com os indicadores e polegares distendidos, tocando-se pelas pontas; com palma para baixo, as mãos se separam, uma movendo-se para a direita, e a outra para a esquerda. No quadro (c), mantendo a mão esquerda ainda configurada no formato final do gesto que constrói a |mesa|, com a mão direita localizada ao centro, o |narrador| 'desenha', com os dedos indicador e polegar unidos, a |rede| da |mesa de pingue pongue|. O 'desenho' da |mesa de pingue pongue| é acompanhado de dois sons de assopro simultâneos aos momentos (b) e (c).

Dada a possibilidade de construir a $\mid$ mesa| orientando as mãos em diferentes direções, a orientação específica das mãos na construção da |mesa| é um dos elementos que nos ajuda a inferir a |posição de visualização| do |narrador| diante da |cena|: tomando como base a Figura 29, o |narrador $\mid$ assume a $\left|\mathrm{PV}_{4}\right|$ na organização conceitual do |cenário| da história: a |posição de visualização| está atrás do |juiz|, que tem, à sua frente, a |mesa de pingue pongue|.

Como pode ser visto na Figura 30 acima, as costas do sinalizador ainda estão um pouco inclinadas para trás como quando localizava a |arquibancada|, sugerindo que, enquanto o |narrador| constrói a |mesa de pingue pongue| em frente ao corpo, a inclinação de seu tronco ainda demonstra aspectos relacionados à |arquibancada|, isto é, à sua inclinação e à sua posição espacial em relação à |mesa| que está sendo localizada no |cenário|. Construindo a relação espacial entre a |arquibancada| e a |mesa de pingue pongue|, o |narrador| realiza o sinal ARQUIBANCADA mais uma vez, como pode ser visto na Figura 31 a seguir.

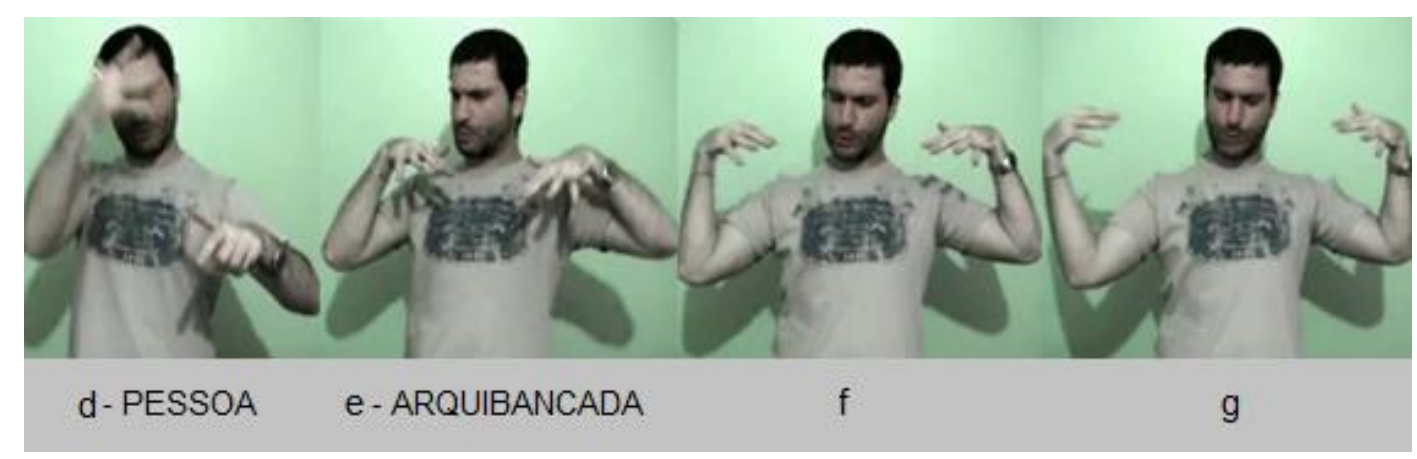

Figura 31 - Pessoas na |arquibancada| de formato arredondado - $\underline{\text { Trecho } 13}$ 
Desta vez, o |narrador| não só apresenta a relação espacial entre a |arquibancada| e a |mesa de pingue pongue|, como também diz que a arquibancada está repleta de gente: no quadro (d), o |narrador|, enquanto mantém a mão esquerda sustentada na configuração final do gesto usado para construir a |mesa|, realiza com a mão direita o sinal PESSOA; no quadro (e), com o tronco inclinado para trás, as sobrancelhas franzidas e as mãos posicionadas à altura dos ombros desde $\mathrm{o}$ início da realização do sinal ARQUIBANCADA, olhando para baixo, o |narrador| sobe as mãos ainda mais para cima dos ombros e, simultaneamente, o torso ainda girando para a direita, movendo-se durante a realização do sinal, até que, em (g), ele está virado para frente. Esse movimento do torso, associada à sua inclinação para trás, sugere que o |narrador| usa o seu tronco para demonstrar o formato da arquibancada. Simultaneamente, a expressão facial assumida pelo |narrador| (sobrancelhas franzidas e lábios ligeiramente arredondados) demonstra o grande tamanho da |arquibancada| e o fato de ela estar repleta.

Em seguida, levando em consideração a organização espacial que deu ao |cenário| com localização da |arquibancada| e da |mesa|, o |narrador| introduz as |personagens|. A primeira personagem localizada é o |juiz|, ao centro do |cenário|, como mostra a Figura 32 abaixo.

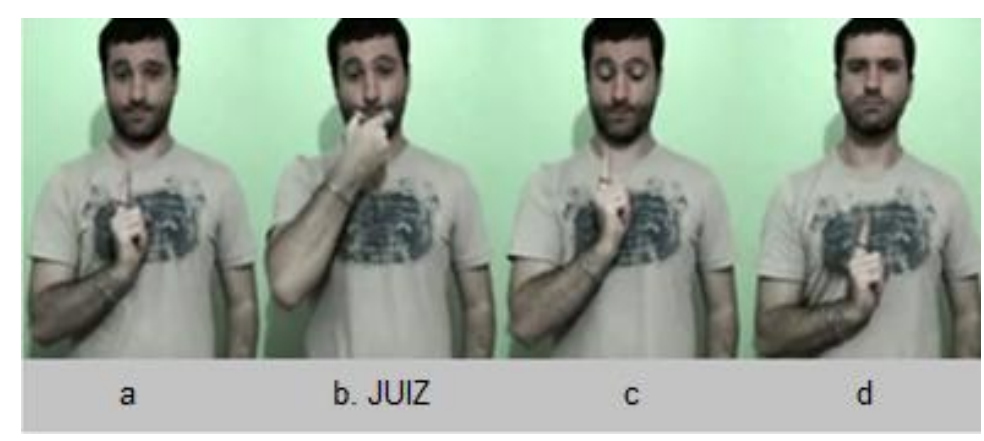

Figura 32 - Localização do |juiz| ao centro do |cenário|- Trecho 14

Embora no quadro (a) da Figura 32, o olhar do |narrador| já esteja direcionado para frente, quando se observa o último quadro da Figura 31, vê-se que, enquanto realizava o sinal ARQUIBANCADA, o |narrador| já direcionava o olhar para baixo, para o centro do |cenário|. Esse direcionamento do olhar para essa região antecede a localização da |personagem| naquele lugar do |cenário|. Usando o gesto convencional icônico em (a), 
cuja configuração se assemelha a uma pessoa em pé, o |narrador| posiciona a |personagem| ao centro do |cenário|: com a mão direita vertical fechada e o dedo indicador distendido, posicionada diante do peito do |narrador| com a palma voltada para a esquerda, o |narrador| realiza um movimento curto, com a mão direita, para baixo (Liddell, 2003:275). Como pode ser observado na Figura 32, o |narrador| demonstra a localização do juiz| próximo à região que corresponde à parte central da lateral da |mesa de pingue pongue|. Em seguida, como o |narrador| não havia dito quem é que está ao centro, ele sinaliza o sinal JUIZ (quadro (b)), e, depois de olhar novamente para a região ao centro e abaixo, realiza novamente o gesto que representa iconicamente uma pessoa em pé (quadro (c)), localizando a |personagem| com um movimento da mão para baixo. Esse movimento de mão para baixo parece ser recorrente na localização de |entidades| em |cenários|, como visto nos exemplos anteriores, apresentados tanto em língua sinalizada quanto em gestos co-ocorrentes à fala oral (Capítulo 2). ${ }^{55}$

Durante toda localização das |personagens| na narrativa sob análise, percebe-se que as expressões faciais do |narrador| se modificam: na figura acima, nos quadros (a), (b) e (c), o |narrador| mantém as sobrancelhas bem levantadas e, no quadro (d), observase que a expressão facial muda, tornando-se séria. Não somente isso: nota-se que, já no primeiro quadro, o |narrador|, localizando o corpo ao centro do espaço de sinalização, mantém as costas eretas. Embora neste momento seja difícil perceber que as expressões faciais e postura corporal estão sendo usadas para caracterizar a |personagem|, à medida que a narrativa avança, percebemos que a expressão facial e a postura corporal assumidas em (d) são semelhantes àquelas que vão retomar o juiz| em vários momentos da narrativa. ${ }^{56}$

Depois de localizar o juiz| ao centro, o |narrador| passa a localizar os dois |jogadores|, em lados opostos da |mesa|, como ilustra a Figura 33 a seguir.

\footnotetext{
${ }^{55}$ A localização da mão é acompanhada de alguns sons 'vocais' que contribuem para a construção da demonstração da localização da |personagem|. Apesar disso, eles não são feitos para demonstrar nenhum aspecto perceptível do evento; por isso, não estou considerando essas ocorrências de sons como demonstrações propriamente, embora considere que elas contribuam com a construção/entendimento da demonstração manual de localização das |personagens|.

${ }^{56}$ Barbosa (2013) estudou, também de uma perspectiva multimodal, o processo de referenciação em uma narrativa sinalizada em libras. A autora mostra que uma das estratégias de retomada referencial de personagens é o uso de parte das demonstrações feitas para caracterizá-las inicialmente.
} 


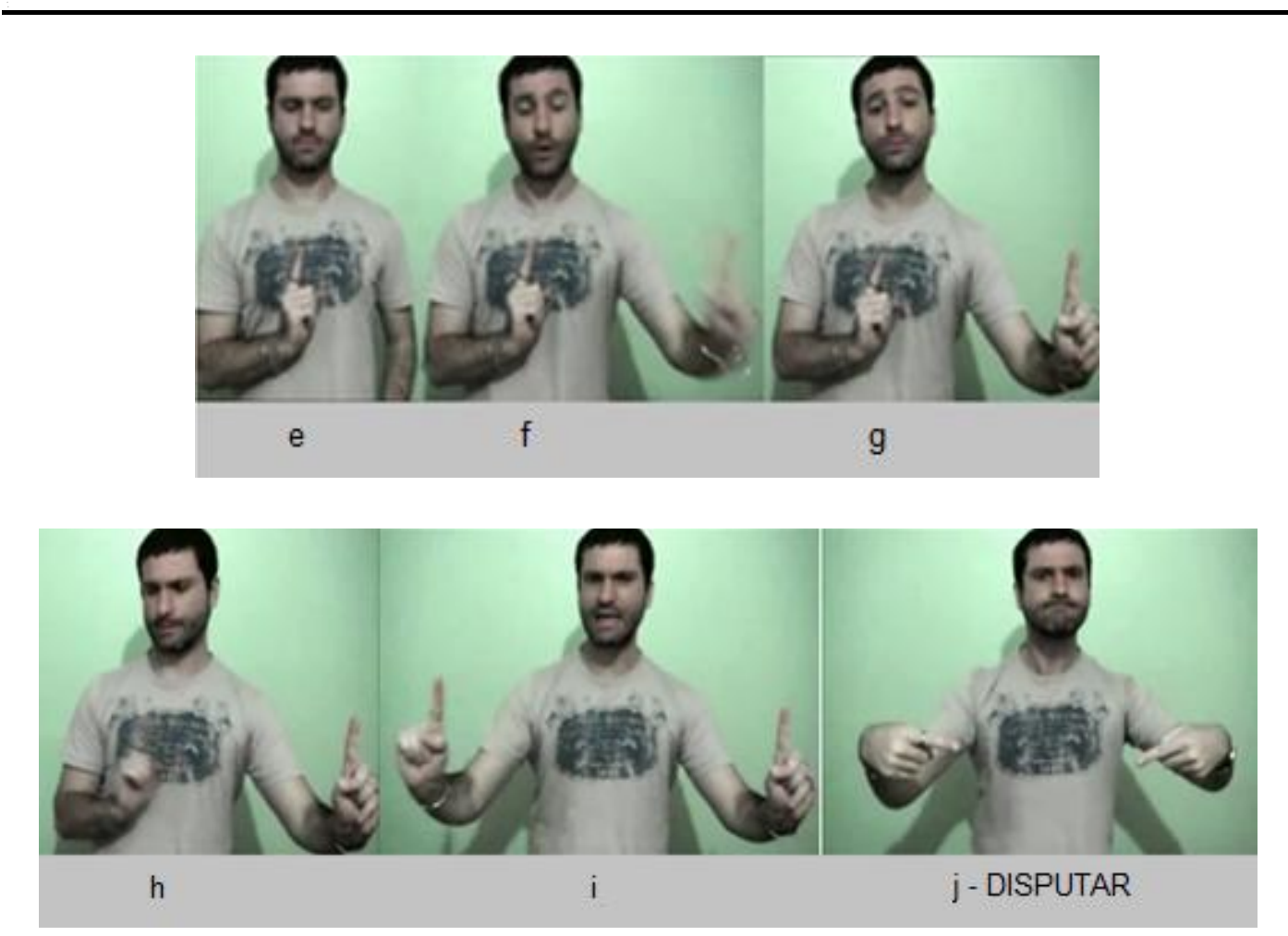

Figura 33 - Localização dos |jogadores| à cabeceira da |mesa |- Trecho 15

Como foi feito na localização do |juiz|, o |narrador| localiza as duas |personagens| usando o gesto icônico convencional que significa 'pessoa em pé'. A localização das mãos nas regiões que correspondem às cabeceiras da |mesa de pingue pongue| é precedida, nos quadros (e) e (h), de um direcionamento do olhar para as regiões onde as mãos vão ser posicionadas. Diferente da maneira como o |narrador| introduz o ljuiz|, a introdução dos dois |jogadores| não é precedida de um sinal para designar as |personagens|; contudo, no momento em que a mão é posicionada na região para onde o |narrador| tinha olhado, a expressão facial se modifica: localizando um jjogador|, primeiramente à esquerda (quadros $(\mathrm{e})$ - $(\mathrm{g})$ ), o |narrador| levanta as sobrancelhas, fecha um pouco os olhos e deixa os lábios ligeiramente arredondados (quadro $(\mathrm{g})$ ), que sugere uma expressão facial tranquila; localizando o outro jjogador| na região que corresponde ao lado oposto da $\mid$ mesa|, o |narrador| modifica a expressão facial novamente (quadro (i)): com as sobrancelhas franzidas e a boca um pouco aberta, com os dentes à mostra, o |narrador| demonstra a expressão facial brava daquela |personagem|. Simultaneamente à localização das mãos em cada uma das regiões, o |narrador| faz um 'som vocal'. 
Note-se que, embora, no quadro (i), os únicos elementos do |cenário| que estão visíveis na demonstração sejam os |jogadores|, localizados à direita e à esquerda, os demais elementos do |cenário|, introduzidos anteriormente, continuam sendo entendidos como estando presentes: enquanto o juiz|, nos quadros (e) até (g), é um elemento visível do |cenário|, a partir do quadro (h), tem início a localização dos |jogadores|, mas o jjuiz| fica integrado à região do espaço ao centro, sendo entendido que ele ainda está presente naquele lugar. Da mesma maneira, a |arquibancada| e a |mesa de pingue pongue| são entendidas como estando presentes na região em que foram inicialmente localizadas. ${ }^{57}$ Como não é possível usar o corpo para demonstrar todos os elementos da narrativa, alguns deles são integrados ao corpo, tornando-se elementos visíveis da demonstração; outros são mantidos por localização anterior no espaço e outros, ainda, são inferidos, a partir da construção imaginária do |cenário| da demonstração.

$\mathrm{O}$ |narrador| encerra esse trecho com o sinal DISPUTAR, que descreve o tipo de evento que acontecerá entre as |personagens|. Na realização do sinal DISPUTAR, a iconicidade dos gestos manuais usados para representar os jjogadores| é aproveitada: com as mãos configuradas como mostra o quadro (i) acima, e posicionadas em pontos opostos do espaço, demonstrando a localização dos |jogadores|, o |narrador| aproveita a iconicidade dos gestos e da localização das mãos para realizar, em seguida, DISPUTAR: com as mãos verticais fechadas e os dedos indicadores distendidos, palma para dentro, cada uma delas localizada na região onde uma |personagem| foi localizada, as mãos se movem para a posição horizontal, dedos indicadores apontando um para o outro. No quadro (j), simultaneamente à realização do sinal manual, o |narrador| franze as sobrancelhas e aperta os lábios: a expressão facial séria demonstra a avaliação do |narrador| sobre a competição: a disputa será realmente acirrada.

Localizando, em seguida, as mãos uma de frente para a outra novamente, o |narrador| demonstra a posição dos |jogadores| um em relação ao outro e usa o corpo e a

\footnotetext{
57 Liddell (2003) diz que o sinalizador pode criar entidades visíveis ou invisíveis durante uma demonstração: as demonstrações que criam entidades visíveis são aquelas integradas ao corpo do sinalizador; entidades invisíveis são criadas a partir de localização de referentes no espaço de sinalização, e são identificadas por apontamentos em direção à região do espaço onde foram localizadas, ou pela maneira como se comportam no espaço de sinalização; uma vez que os referentes sejam localizados no espaço de sinalização, eles ficam disponíveis para futuras menções. Para um estudo de referenciação em narrativas contadas em libras, ver Barbosa (2013).
} 
expressão facial para demonstrar a tensão envolvida no momento, como pode ser visto na Figura 34 a seguir.
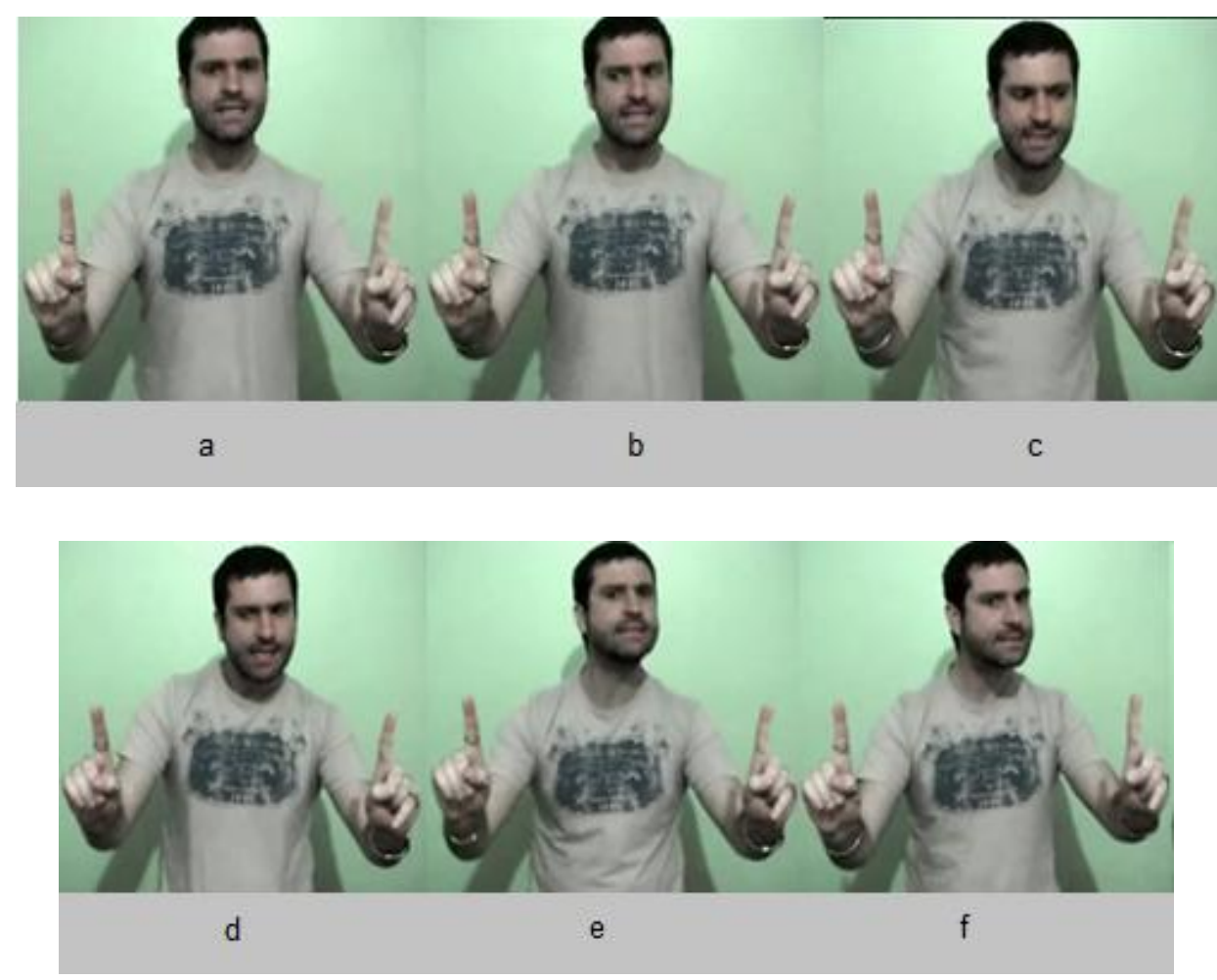

Figura 34 - Demonstração de tensão envolvida nas preliminares do jogo - $\underline{\text { Trecho } 16}$

No quadro (a), o |narrador| posiciona as mãos paralelamente, realizando com cada uma das mãos, os gestos que significam 'pessoa em pé', com um movimento curto para baixo; seu olhar está dirigido para seu interlocutor, o que indica que, aqui trata-se de uma ação do narrador, exclusivamente. Na sequência (quadros (b) a (d)), com as mãos assim posicionadas, o narrador| olha para a mão direita (quadro (b)), depois para a mão esquerda (quadro (c)) e novamente para a mão direita (quadro (d)), enquanto demonstra corporalmente a ação de ofegar tão fortemente que chega a balançar todo o corpo. Há uma ambiguidade aqui. Como o |narrador| não rotula quem está olhando para as mãos e ofegando, não fica explícito se o direcionamento do olhar e os movimentos do corpo correspondem a comportamentos do |narrador|, que, ao apresentar as |personagens| por meio dos gestos manuais icônicos, demonstra, ofegando, a tensão do momento; se 
correspondem a atitudes do |juiz|, que, posicionado ao centro, olha para os dois |jogadores|; ou, ainda, se correspondem a comportamentos dos |jogadores|, que, o |narrador| integrando, em cada momento, cada um ao seu corpo, demonstra um |jogador| olhando para o outro e a tensão que existe entre os dois.

A partir do momento em que o |narrador| posiciona os elementos do |cenário| no espaço de sinalização, a organização espacial passa a ser útil na estruturação da história: uma vez que a narrativa é atuada no espaço de sinalização (McCleary \& Viotti, 2014), a manutenção de uma determinada configuração de cenário é importante para mostrar as |personagens| agindo no |cenário| da história. A organização do |cenário| pode ser feita em dimensão reduzida, no espaço em frente ao corpo, como foi mostrado acima, ou inserindo as |personagens| num |cenário| de dimensão real, como será apresentado a seguir.

Embora em uma mesma narrativa possa haver a atuação de |personagens| em diferentes |cenários|, exibindo a reorganização espacial do |cenário| da história na passagem de um |cenário| a outro, as ações das |personagens| na narrativa 'Bolinha de Ping-Pong' acontecem todas em um único |cenário|; como as |personagens| ainda permanecem no mesmo lugar do começo ao fim, a organização espacial do |cenário| se mantém até o fim da narrativa, sem que haja mudança de |cenário| ou mudança na organização do |cenário|. ${ }^{58}$ Conforme foi apresentado acima, as ocorrências de demonstração da narrativa "Bolinha de Ping Pong" são elaboradas em relação à organização espacial representada na Figura 35 abaixo, a partir da |posição de visualização| do |narrador|, que, nas sequências apresentadas acima, é externa ao espaço conceitual do |cenário| da história.

${ }^{58}$ Para uma análise de narrativa sinalizada em que há mudanças de |cenário|, ver Barbosa (2013). 


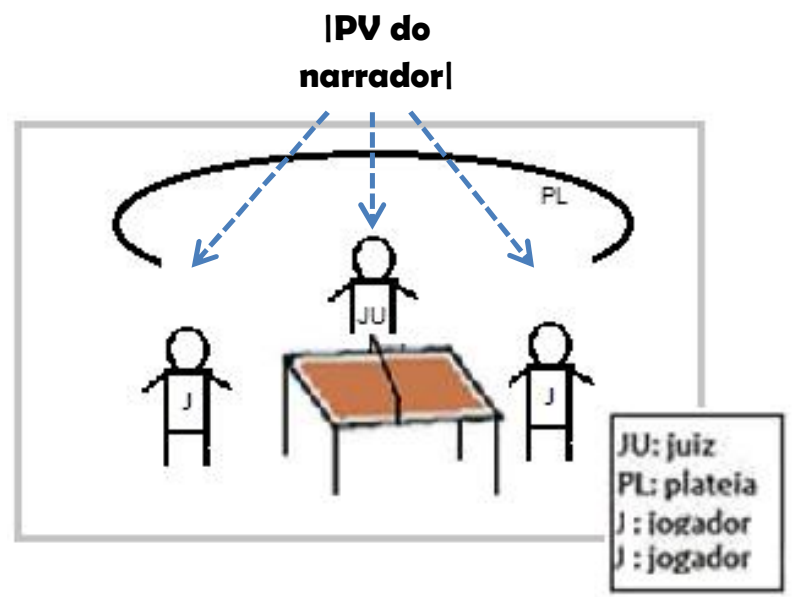

Figura 35 - Esquema da organização espacial da narrativa "Bolinha de Ping Pong"

A única reorganização conceitual do |cenário| na narrativa sob análise, se dá, como se verá adiante, pela mudança da |posição de visualização| do |narrador| para alguma |personagem| e da |personagem| para o |narrador| ou para outra |personagem|, mas não por alteração da posição das |personagens| no |cenário| ilustrado na figura acima - exceto no caso da |bolinha| que, a partir de um dado momento, começa a se mover de um lado a outro do |cenário|.

\section{Caracterização das personagens}

Depois de apresentar o |cenário| em dimensão reduzida em frente ao seu corpo, o |narrador|, aproveitando essa organização espacial, começa a demonstrar as ações das |personagens| da história.

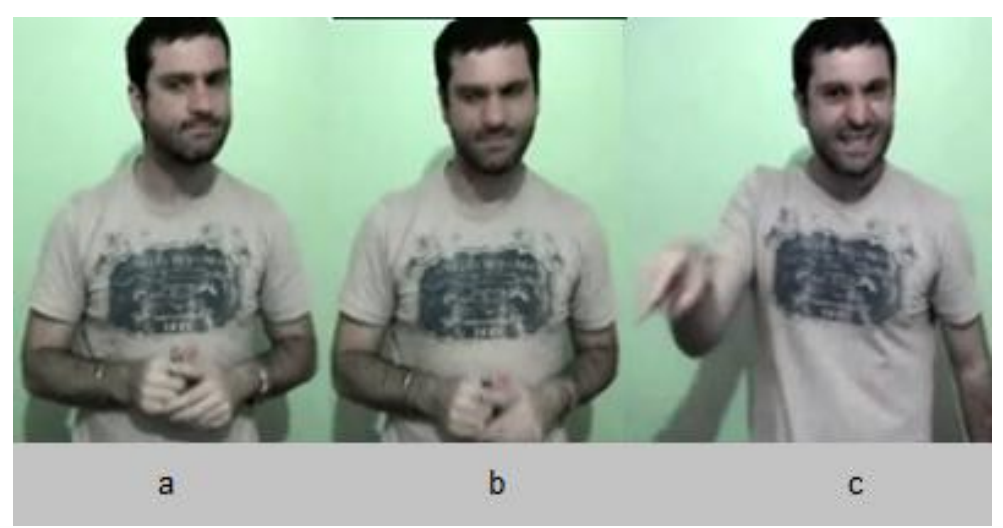




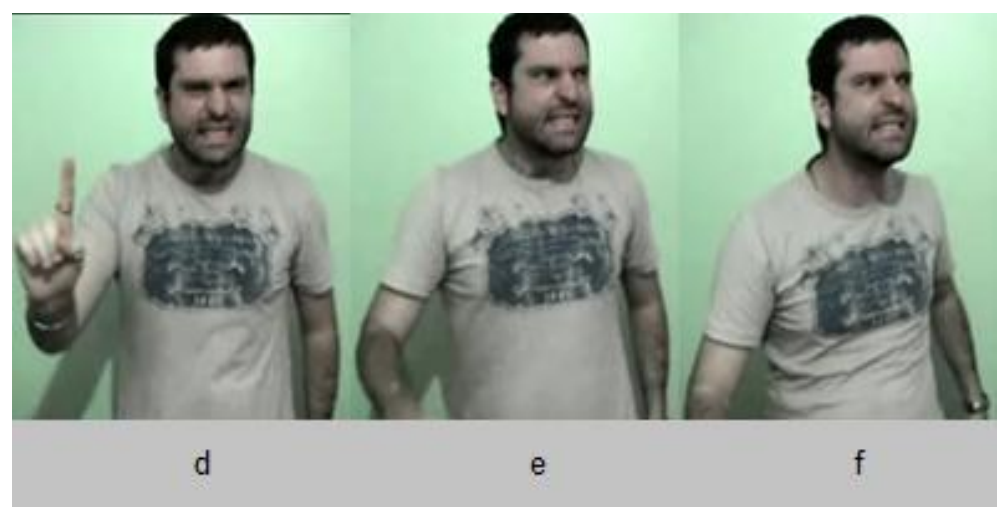

Figura 36 - Demonstração de postura corporal e expressões do |jogador| da direita - $\underline{\text { Trecho } 17}$

Como pode ser observado na Figura 36, o |narrador| volta as mãos para a posição de repouso (quadro (a)) e, em seguida, direciona o olhar para a região onde havia localizado um dos jjogadores| (quadro (b)); franzindo as sobrancelhas e direcionando o olhar para câmera, o |narrador| aponta para aquela região (quadro (c)). Nesse momento, a expressão facial do |narrador| já começa a se modificar para caracterizar o |jogador| da direita; no quadro (d), realizando o gesto que significa 'pessoa em pé' - desta vez sem realizar nenhum movimento para baixo no posicionamento do gesto no espaço à direita $\mathrm{o} \mid$ narrador| representa iconicamente o jjogador| em pé naquela região por meio do mesmo gesto usado (e descrito) anteriormente. No quadro (d), com os dentes à mostra, as sobrancelhas bem franzidas e os olhos semifechados, o |narrador| caracteriza a expressão facial do |jogador| da direita, já representado pelo gesto icônico realizado pela mão direita. Nesse momento, o |narrador| demonstra, simultaneamente, dois aspectos visuais associados à |personagem|: a sua localização no |cenário| e a sua expressão facial, que mostra que o jjogador| está/é bravo.

No quadro (e), o |narrador| volta as mãos para baixo, e, virando o corpo para a esquerda e direcionando o rosto e o olhar para o mesmo lado, usa todo o corpo para demonstrar a postura do |jogador|, posicionado à direita, e olhando para o seu oponente, do outro lado da |mesa|. Nesse momento, um novo domínio de ação se instaura na narrativa e, a partir de então, a postura do corpo, as expressões e as suas ações passam a ser entendidas como sendo da |personagem|. Na passagem para a demonstração da postura corporal da |personagem|, o |narrador|, posicionando o corpo à direita, aproveita o 
posicionamento que já havia dado àquela |personagem| por meio do gesto manual, na elaboração do |cenário| em dimensão reduzida. A diferença está no fato de que, ao usar o corpo inteiro para realizar a demonstração, o espaço conceitual do |cenário| previamente construído em dimensão reduzida é agora ampliado, porque ele inclui o corpo inteiro do sinalizador, que, por meio de uma integração conceitual, é entendido como sendo o corpo da |personagem|. A |posição de visualização| da cena, a partir de agora, não é mais do |narrador|, mas da própria |personagem|, que, inserida no |cenário|, olha para o lado oposto da $\mid$ mesa|, onde está localizado o seu oponente. O |cenário|, que era visto até então pelo |narrador| de uma posição superior e externa, é visto, a partir de agora, da perspectiva da |personagem|, que é interna ao |cenário|, e que, portanto, tem uma escala compatível ao corpo da |personagem|.

A mudança de |posição de visualização| do |narrador| para a |personagem| promove uma alteração na organização do |cenário|, em dois aspectos: como o corpo inteiro do sinalizador está sendo usado para fazer referência à |personagem|, e porque a |posição de visualização| é dela, o |cenário|, passa a ser conceitualizado como sendo de dimensão real. Como a |posição de visualização| é do |jogador| localizado à direita, a |mesa de pingue pongue|, que havia sido construída em frente ao peito do |narrador| em escala reduzida, a partir da inclusão da |personagem| no |cenário| de escala real, passa a ser entendida como estando posicionada à esquerda, na região que corresponde à frente do corpo do jjogador|.

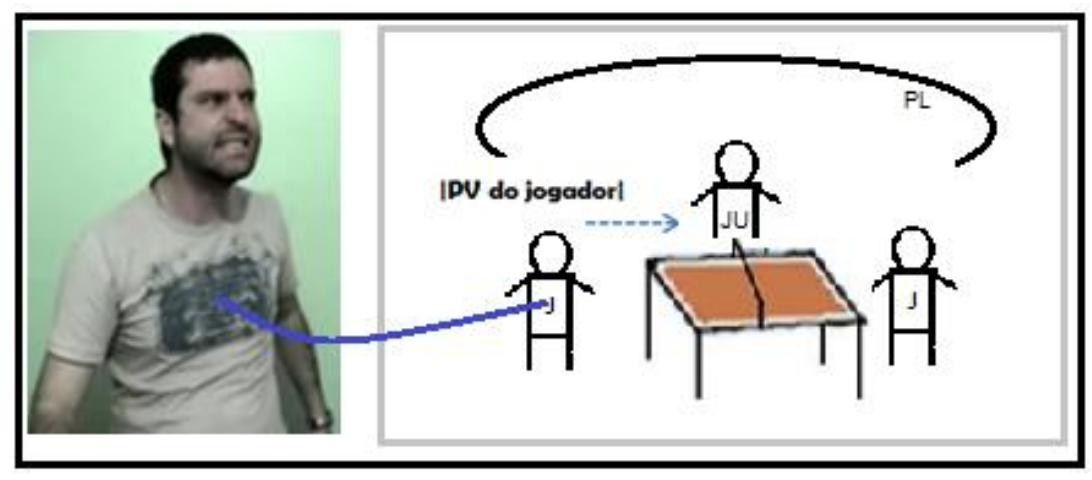

Figura 37 - Posição de visualização do |jogador| da direita, interna ao cenário de escala de dimensão 'real'

No quadro (f) da Figura 36, repetida acima na Figura 37, o |narrador| demonstra a postura do |jogador| da direita e a sua expressão facial de raiva, olhando para o seu oponente no lado oposto da mesa. Embora o jogador| da esquerda não tenha sido 
mencionado em escala real, uma vez que um elemento do |cenário| é redimensionado, todo o |cenário| ganha nova dimensão e os elementos anteriormente apresentados em escala reduzida são agora todos entendidos como sendo de dimensão real.

Aproveitando que a demonstração da postura do |jogador| da direita já foi apresentada, o |narrador| libera as mãos para narrar: como pode ser visto na Figura 38 a seguir, enquanto o corpo está virado para a esquerda, entendido como sendo o corpo da |personagem|, as mãos, não mais da |personagem|, mas do |narrador|, são usadas para demonstrar, de maneira pictórica, as características físicas do |jogador|, que tem uma barba de formato arredondado e um cabelo grande, que emenda com a barba e dá até para pentear.
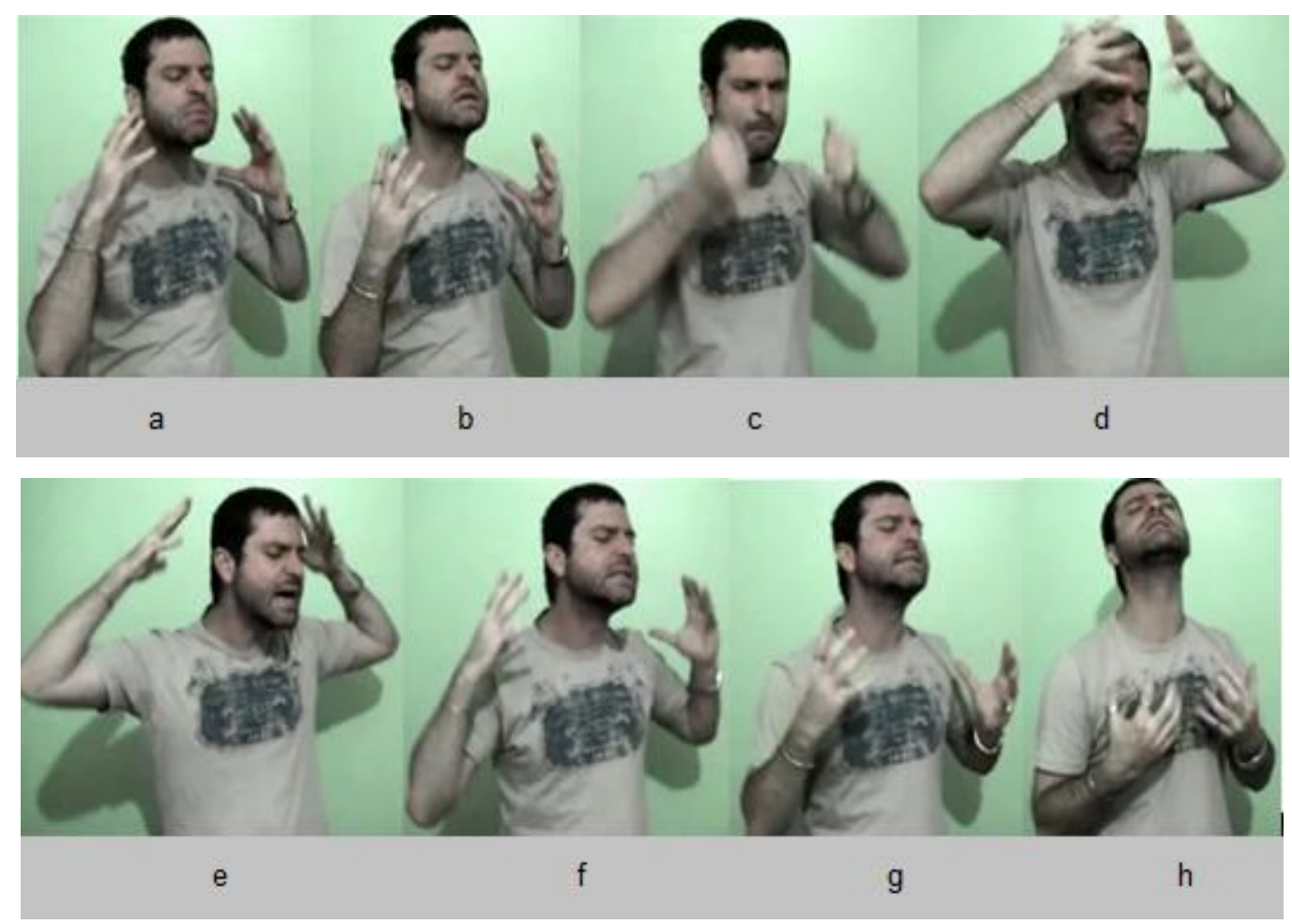


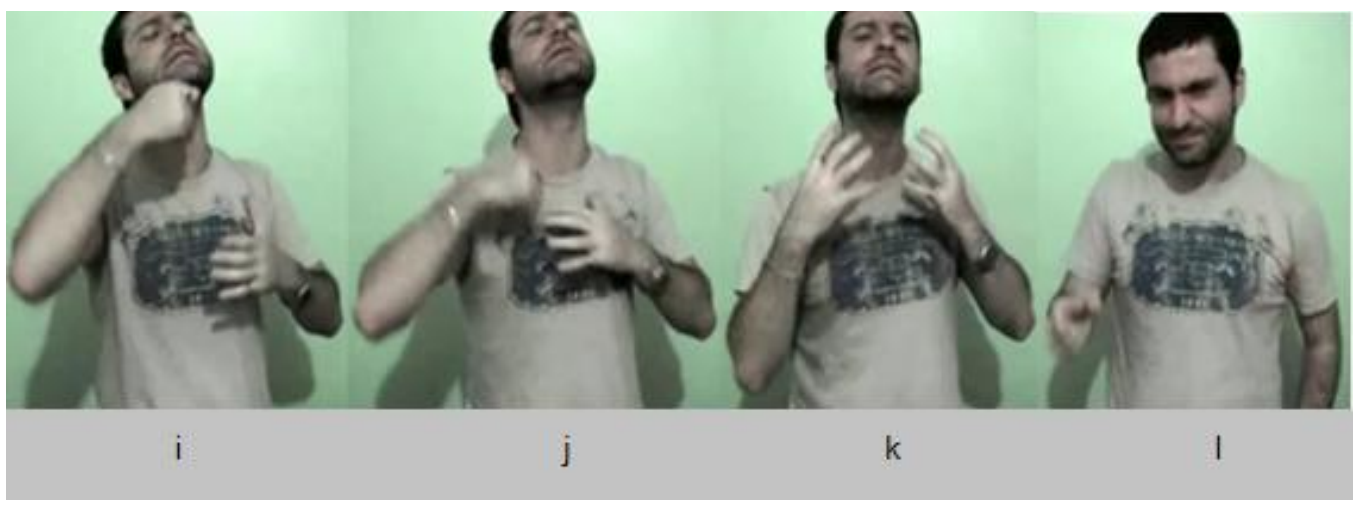

Figura 38 - Demonstração pictórica de características do |jogador| da direita - Trecho 18

$\mathrm{Na}$ figura acima, enquanto a postura do corpo é entendida como sendo da |personagem|, os gestos manuais são ações do |narrador|: nos quadros (a) e (b), o |narrador| usa as mãos para demonstrar o formato arredondado da barba; no quadro (c), (d) e (e), o |narrador| demonstra o tamanho do cabelo; nos quadros (f), (g), (h), o |narrador| 'emenda' o gesto usado para significar a extensão do cabelo emendando com a barba. Nos quadros (i) e (j), o narrador| realiza uma demonstração de pentear a barba. Essa demonstração não significa que o jjogador barbudo| esteja se penteando antes do jogo, mas que o jjogador barbudo| tem uma barba e um cabelo bem penteados, ou que são tão longos que podem ser penteados. O |narrador| termina a caracterização pictórica do |jogador barbudo| virando o corpo para a direita e a apontando mais uma vez para a direita, mantendo as sobrancelhas ainda franzidas como parte da caracterização da expressão facial do jjogador barbudo|. Observe-se que, neste momento, o |narrador| assume novamente a |posição de visualização| externa ao |cenário| e aponta para a mesma região onde ele havia localizado o jjogador barbudo| no |cenário| de dimensão reduzida.

Em seguida, o |narrador|, ainda assumindo uma |posição de visualização| externa em relação ao |cenário|, localiza a outra |personagem| à esquerda e, em seguida, demonstra a postura dessa |personagem|, como ilustra a Figura 39 a seguir. 


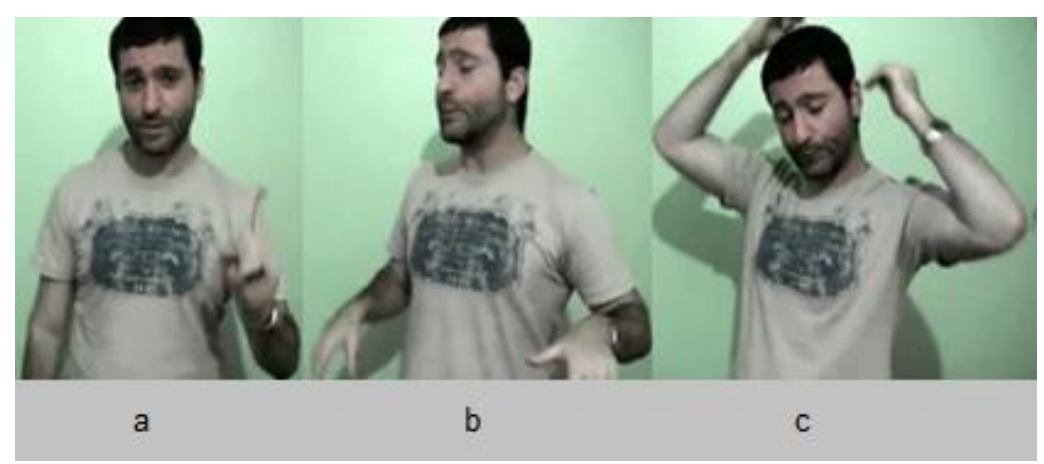

Figura 39 - Demonstração de postura corporal e expressões do |jogador| da esquerda - Trecho 19

Com o torso já virado para a direita, o |narrador| realiza, com a mão esquerda (quadro (a)), o gesto icônico que significa 'pessoa em pé' à esquerda, na região onde ele havia localizado a |personagem| anteriormente. Virando o torso um pouco mais para a direita (quadro (b)), e mantendo ambas as mãos suspensas à altura do abdômen com os dedos apontando para baixo e os punhos relaxados de modo a que as mãos pendam para baixo, o |narrador| demonstra a posição da |personagem| no |cenário|, que novamente assume dimensão real, e demonstra também a sua postura corporal e as suas expressões faciais e corporais: nesse momento, como no momento em que a |personagem| havia sido primeiramente localizada no |cenário| de dimensão reduzida, o |narrador| levanta as sobrancelhas e configura os lábios de modo que eles fiquem arredondados; nesse momento, os olhos estão fechados.

Em seguida, como havia feito para caracterizar o jogador barbudo - mantendo o corpo virado, desta vez para a direita, demonstrando a posição do corpo da |personagem| e a sua localização no |cenário| de tamanho real -, o |narrador| libera as mãos para caracterizar a |personagem|, que usa uma boina com um enfeite grande e está perfumada, de luvas e de batom, segurando a raquete de uma maneira delicada, como ilustra a Figura 40 a seguir. 

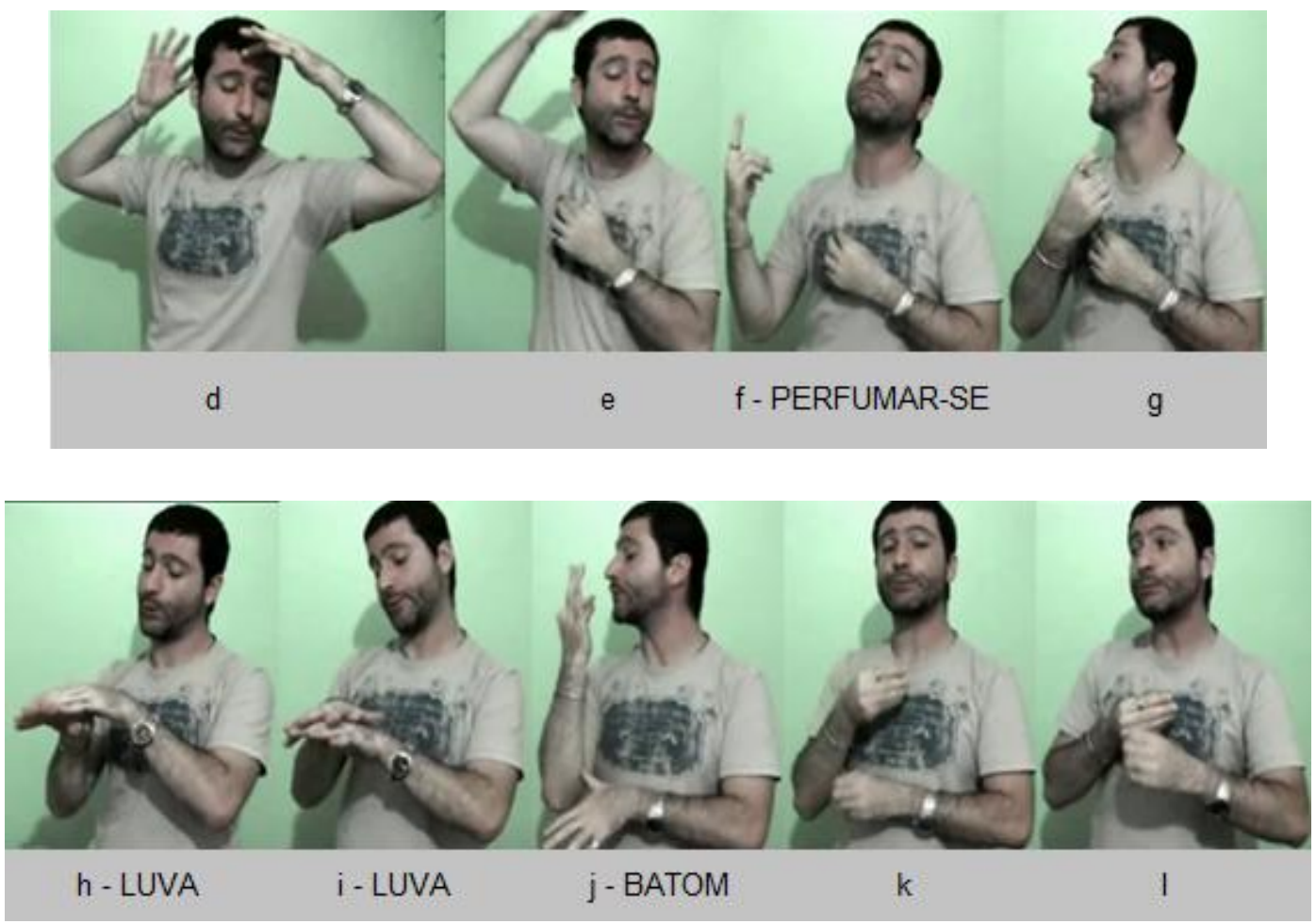

Figura 40 - Demonstração/descrição de

características do |jogador delicado | - Trecho 19

Como pode ser observado na figura acima, para caracterizar essa |personagem|, o |narrador| usa uma sequência de gestos e de sinais icônicos: primeiramente, o |narrador| usa gestos icônicos para mostrar que a |personagem| usa uma boina (quadro (d)), que tem um arranjo bem grande (quadro (e)). No quadro (d), com as mãos abertas, com os dedos indicadores e o polegar um pouco curvados, palma para dentro, o |narrador| posiciona as mãos um pouco acima da cabeça, de maneira que os dedos indicador e polegar formem um semicírculo na horizontal; esse gesto icônico, posicionado um pouco inclinado na cabeça, se assemelha à maneira que uma 'boina' se assenta na cabeça; em seguida, o |narrador|, com os dedos indicador e polegar da mão direita distendidos e paralelos na altura da cabeça, move a mão para trás, para significar que a boina tem uma 'fitinha' (quadro (d)). Depois, o |narrador| move a mão horizontal aberta, com dedos um pouco curvados, palma para baixo, dedos unidos, ao lado direito da cabeça para construir iconicamente o arranjo da boina (quadro (e)). 
Em seguida, o |narrador| usa sinais icônicos, para caracterizar a |personagem|: ele realiza os sinais PERFURMAR-SE (quadros (f) e (g)), LUVA (quadros (h) e (i)) e BATOM (quadro (j)). Nesse momento, a iconicidade dos sinais e gestos é aproveitada para compor a demonstração que caracteriza fisicamente a personagem: uma vez que, a partir do quadro (b) da Figura 39, o corpo posicionado à esquerda é entendido como sendo da |personagem|, os gestos realizados nos quadros (d) e (e) podem ser entendidos como sendo a |boina| na cabeça da |personagem|; da mesma maneira, a realização dos sinais PERFURMAR-SE, LUVA e BATOM, enquanto o |narrador| demonstra a postura corporal da |personagem|, significam que é a |personagem| que está perfumada, usando luvas e batom. ${ }^{59}$ No quadro (1), o |narrador| demonstra a ação do ljogador| da esquerda segurando a |raquete| e olhando para o jogador barbudo|, com o corpo e cabeça virados para a direita. Como dito anteriormente, nesse momento da narrativa, existe uma integração conceitual que cria o |jogador delicado|. A |posição de visualização| é entendida, nesse momento, como sendo do jogador delicado|, que, posicionado à esquerda, olha para o |jogador barbudo|, que está à direita. Mudando a |posição de visualização|, toda a organização do espaço é conceitualmente reorganizada, agora como sendo vista a partir da perspectiva do jogador delicado|.

\footnotetext{
$59 \mathrm{Na}$ interpretação de uma determinada demonstração, os interlocutores precisam levar em consideração todas as pistas que eles têm disponíveis até o momento. Uma dessas pistas é o próprio conhecimento de mundo que ele tem a respeito daquilo que é demonstrado. Por isso, apesar de, ao observar essa sequência, termos a impressão de ver a |personagem / se perfumando, colocando as luvas e passando batom, sabemos que a |personagem| não está se perfumando, colocando luvas e passando batom antes de começar o jogo. Essas demonstrações não correspondem a ações da personagem no |cenário| do evento, mas à fala do |narrador|, que, por meio de demonstrações - realizadas pela integração entre a postura corporal da |personagem| e os gestos e sinais icônicos - caracterizam a |personagem|.
} 


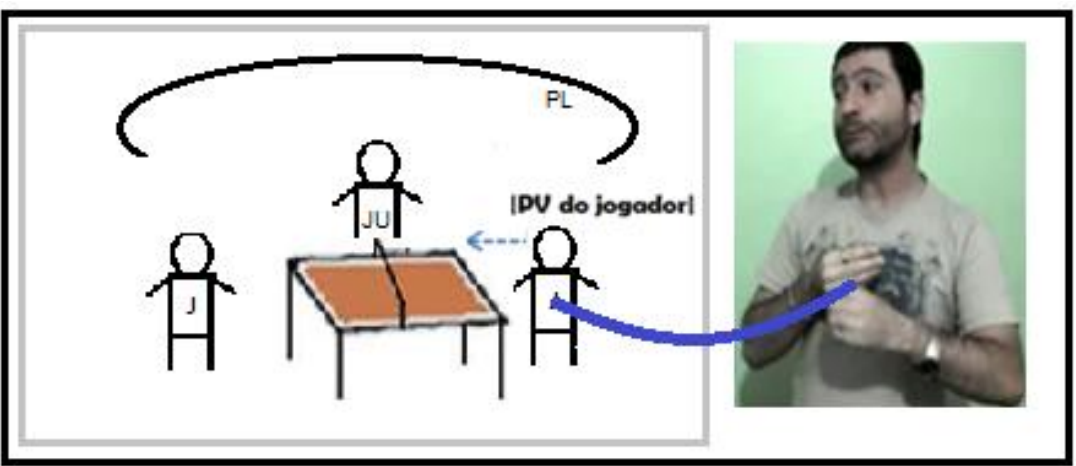

Figura 41 - Posição de visualização do |jogador| da esquerda, interna ao cenário de escala de dimensão 'real'

Em seguida, como mostra a Figura 42 abaixo, depois de olhar para câmera, o |narrador| vira novamente o corpo para a esquerda e olhando para essa mesma direção, demonstra o |jogador barbudo| segurando a |raquete|, ofegante.
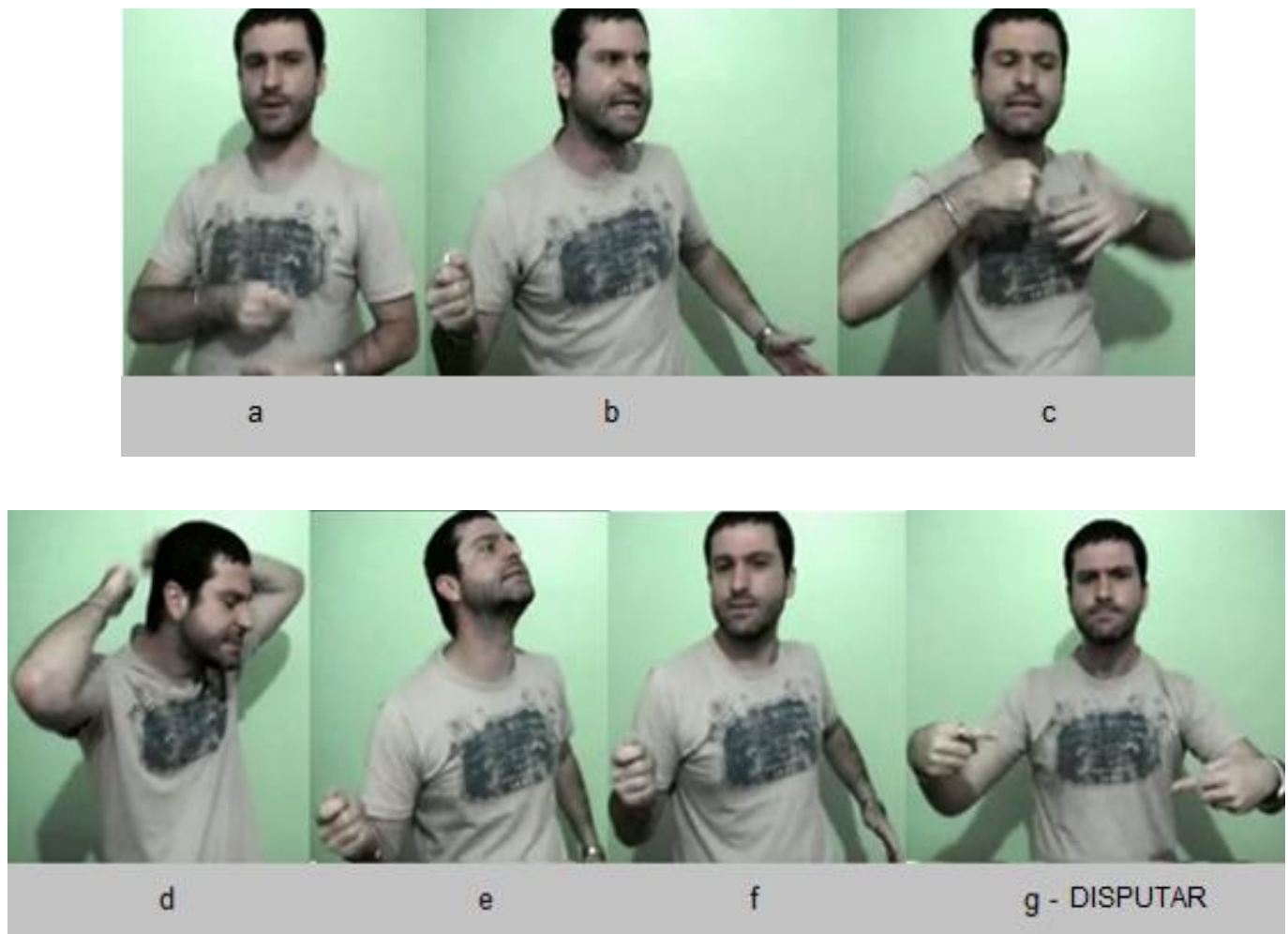

Figura 42 - Demonstração de postura corporal e caracterização do |jogador barbudo| - Trecho 20 
No quadro (a), vemos o |narrador| olhando para a câmera na passagem da demonstração da postura do |jogador delicado| para a demonstração da postura do jjogador barbudo|; no quadro (b), o |narrador| já está demonstrando a postura do |jogador barbudo| segurando a |raquete| com a mão direita. Em seguida, as demonstrações nos quadros (c) e (d) correspondem à caracterização que o |narrador| faz do |jogador barbudo|: é o |narrador| quem diz que o jogador barbudo| tem uma barba e um cabelo bem penteados. $\mathrm{Na}$ sequência, o |narrador| demonstra o jogador barbudo| segurando a |raquete| e olhando para o seu oponente.

Em seguida, o |narrador|, voltando o corpo para o centro do espaço de sinalização e, com a expressão facial séria, realiza o sinal DISPUTAR, para dizer que os dois |jogadores| apresentados estão competindo; a expressão facial do |narrador|, nesse momento, demonstra uma avaliação a respeito da partida, que realmente será bastante tensa.

\section{Ações do jogo}

A partir desse momento, o |narrador| passa a apresentar as ações do jogo; antes disso, contudo, ele apresenta a última |personagem| da história, que é a bolinha de pingue pongue. Esse trecho é aberto com a demonstração de uma ação do |juiz|, como pode ser visto na Figura 43 a seguir.

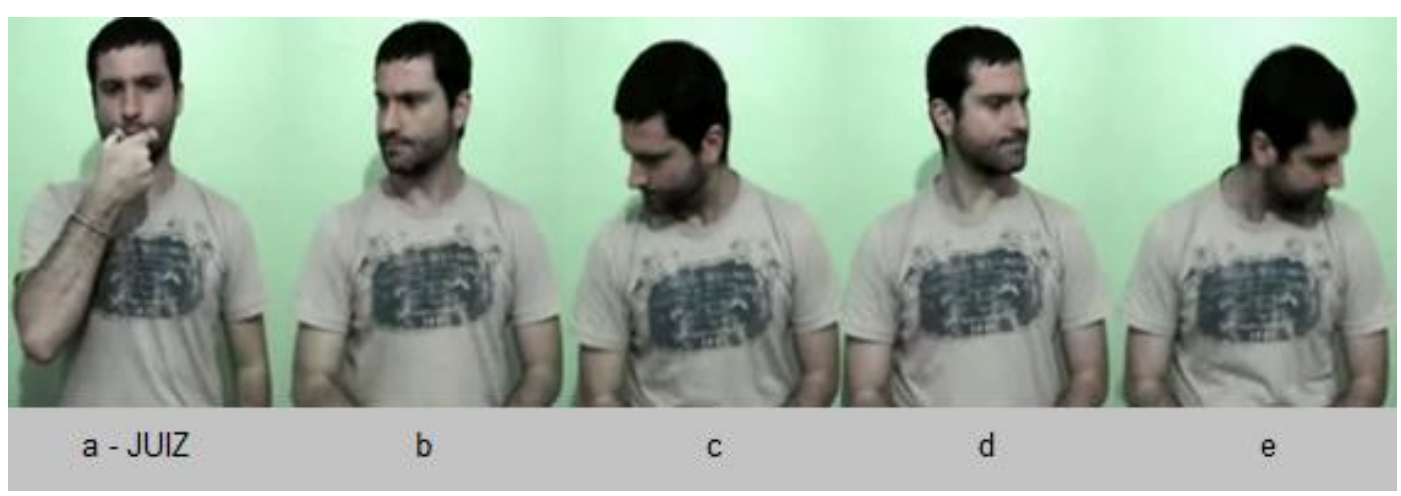

Figura 43 - Demonstração do |juiz| cumprimentando os |jogadores| Trecho 21 
Com o corpo posicionado ao centro, o |narrador| realiza o sinal JUIZ (quadro (a)) e, voltando ambos os braços para a posição de repouso, demonstra a ação do [juiz|, que, virando a cabeça primeiro para a direita, depois para a esquerda, cumprimenta cada um dos jogadores com um aceno de cabeça. Nesse momento, entendemos que é o juiz| quem está agindo, não só por causa da referência a ele feita pelo sinal manual, mas porque as expressões faciais e corporais exibidas pelo |narrador| são semelhantes àquelas que ele já tinha exibido anteriormente para se referir a essa |personagem|: a postura do corpo bem ereta ao centro e a expressão facial séria são comportamentos que, até o momento, são realizados para caracterizar o juiz|.

Posicionado ao centro do |cenário|, o juiz| participa do |cenário| em dimensão real; a |posição de visualização| do |juiz| é interna ao |cenário|.

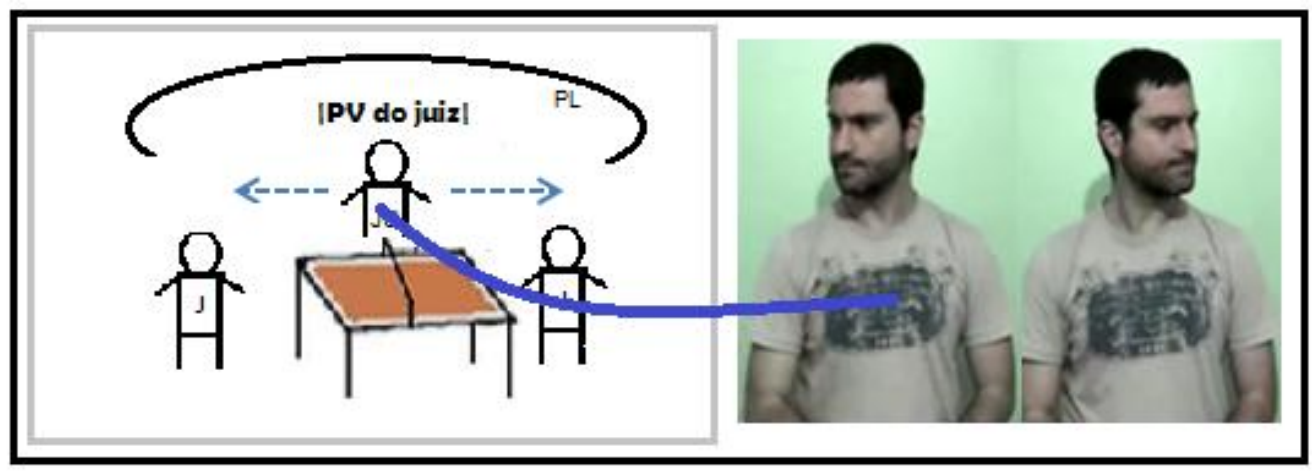

Figura 44 - Posição de visualização do |juiz|, interna ao |cenário| de escala real

Introdução da personagem 'bolinha de pinque ponque'

Depois disso, na figura abaixo, modificando a expressão facial, o |narrador| sorri e demonstra a ação de pegar um |objeto|, que está próximo ao corpo, à direita e abaixo (quadro a). O |narrador| usa um gesto icônico para mostrar que o |objeto| pegado é pequeno e tem formato arredondado (quadro b). Com um aceno de cabeça, e sorrindo, o |narrador| parece perguntar o que é o objeto redondo que está na sua mão. 


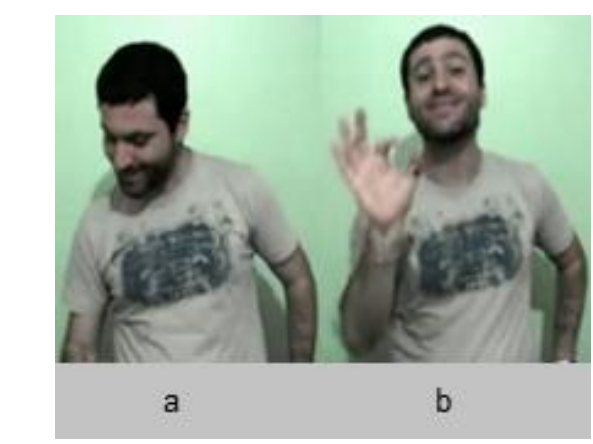

Figura 45 - Demonstração da ação de pegar um | objeto arredondado | - Trecho 22

Sabendo que o juiz| mantém uma expressão bem séria desde o começo da narrativa, nesse momento, somos levados a desconfiar que, embora pareça ter sido o juiz| quem se abaixou para pegar o |objeto| e dar início ao jogo, não parece ser o juiz| quem está sorrindo; com o olhar direcionado para a câmera, parece ser o |narrador| quem, ao demonstrar a ação de pegar um objeto, sorri, porque tem algo a dizer sobre ele.

Cabe dizer que, nesta narrativa, depois de haver introduzido as |personagens| no |cenário| de dimensão 'real', o |narrador| já não retoma o |cenário| de dimensão reduzida: ele mantém o |cenário| de dimensão real até o fim da narrativa. Embora a |posição de visualização| do |narrador| em relação ao |cenário| fosse ao início externa ao |cenário|, como se ele estivesse sendo visto de uma posição superior, a partir deste momento da narrativa, o |narrador| assume uma |posição de visualização| interna ao |cenário|, passando a observar os elementos do |cenário| em volta de si, em uma escala de dimensão real. A |posição de visualização| assumida pelo |narrador| é a localização ao centro do espaço de sinalização, no espaço default, como ilustrado pela figura a seguir. Parece ser circunstancial o fato de essa posição ser coincidente com a do |juiz|; ou seja, nada indica que o juiz| seja o |narrador| da história. 


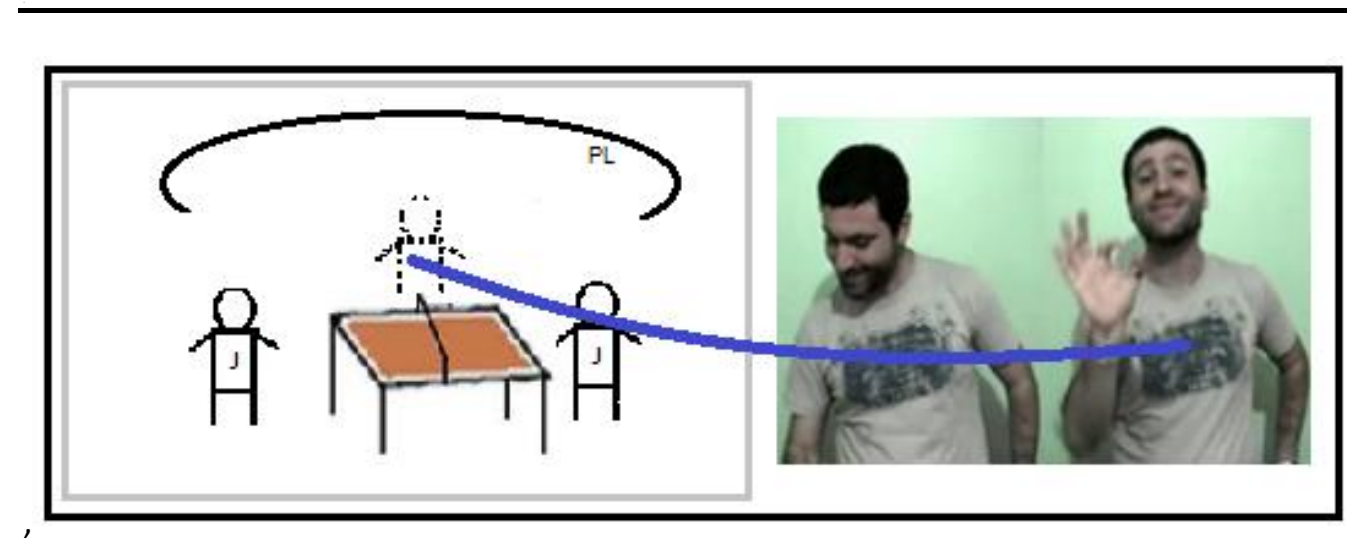

\section{Figura 46 - Posição de visualização do |narrador |, interna ao |cenário|} de escala de dimensão real

Como já foi observado por Dudis nas análises de demonstração em ASL, o fato de o |narrador| assumir uma |posição de visualização| interna ao cenário conceitual de dimensão real não significa que o |narrador| participe corporeamente do |cenário|, como as |personagens| participam: se o |narrador| não for personagem da história, somente a sua |posição de visualização| é interna ao |cenário|, mas o seu corpo não participa do espaço conceitual do |cenário|, como o das |personagens| participam. ${ }^{60}$ Como pode ser observado na figura, a |posição de visualização| do |narrador| concorre com a do |juiz|, pois ambos estão assumindo a mesma |posição de visualização| no |cenário|. Como se verá na análise deste trecho, em que se apresenta a última |personagem| da narrativa, a similaridade da |posição de visualização| do |narrador| e do |juiz|, bem como a semelhança entre as expressões e as ações do |juiz| e do |narrador| torna difícil a distinção entre eles na passagem que segue.

Nesse momento, uma vez que o |cenário| de dimensão real já não é mais desfeito, o |narrador| parece 'entrar’ no |cenário| da história para apresentar a personagem |bolinha|: no quadro (a) da Figura 45, o |narrador| demonstra o |juiz| se abaixando para pegar a |bolinha| para dar início ao jogo; nesse momento, o |narrador| parece perceber que ainda

\footnotetext{
${ }^{60}$ Como Dudis não leva em consideração a figura do |narrador|, a sua análise é a de que, em um caso como esse que estou descrevendo, a | posição de visualização| é um elemento conceitual necessário para a construção de |cenário| de dimensão real e é o único elemento conceitual que participa da integração conceitual na construção do |cenário|, permanecendo o corpo do sinalizador fora da integração (2007: 16). Na Figura 46 uso, como Dudis, uma representação de uma figura humana em pontilhado para significar que somente a |posição de visualização| do |narrador| está inserida no |cenário|, mas que o |narrador| (nas análises de Dudis, o sinalizador) não participa do |cenário|, como |personagem| da história.
} 
não apresentou a |bolinha|, que também é uma |personagem| animada da história, e, então, interrompe a demonstração da ação do |juiz| e ele, |narrador|, passa a apresentá-la. No quadro (b) da Figura 45 é o |narrador| quem, realizando um gesto que significa 'objeto pequeno arredondado', acena com a cabeça e pergunta o que é esse |objeto pequeno arredondado| que ele tem nas mãos, representado pelo gesto icônico. O sorriso do |narrador| parece se explicar pelo que vem em seguida: realizando o sinal PALHAÇO, como mostra a figura a seguir, o |narrador| afirma que aquele objeto redondo é, na verdade, um nariz de palhaço.
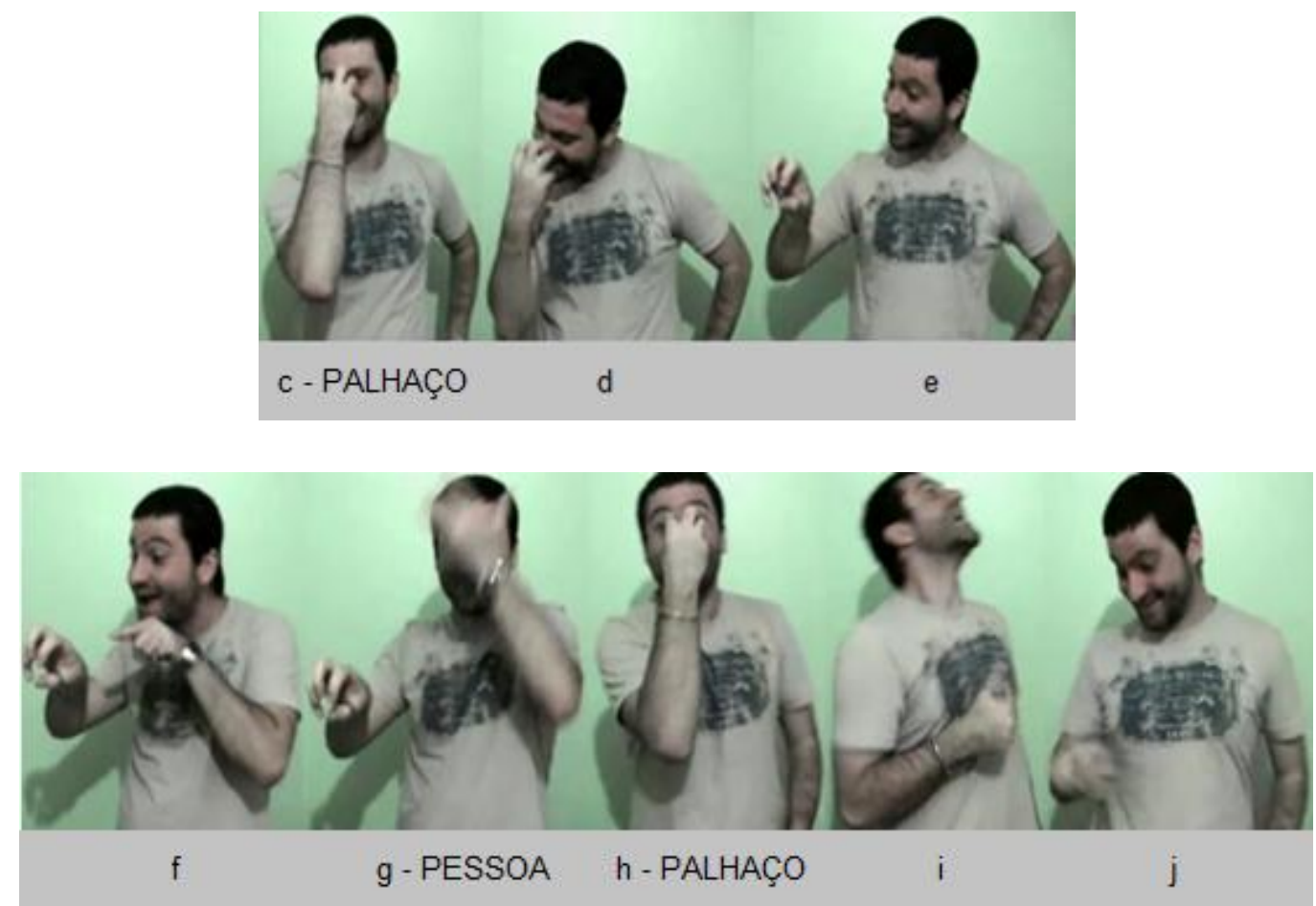

Figura 47 - Apresentação da personagem | bolinha/nariz de palhaço| Trecho 23

Durante o trecho apresentado na figura acima, o |narrador| continua explicando: sorrindo, ele diz um enunciado que poderia ser traduzido como esta bolinha é um palhaço que concorda animadamente com o juiz. Como pode ser observado no trecho que vai do quadro (c) ao (i), a apresentação da |bolinha| é feita por uma combinação de descrição e demonstração: primeiramente o |narrador| sinaliza PALHAÇO (quadro (c)) e, em seguida, curva o torso para baixo e, embora a foto não capture esse movimento, realiza a 
demonstração de pegar o |objeto pequeno arredondado| com a mão direita, posicionandoo na região do nariz, como na realização do sinal PALHAÇO: olhando para a câmera enquanto realiza o sinal PALHAÇO, o narrador| transmite a ideia de que o lobjeto pequeno arredondado| que foi pego é um nariz de palhaço; a passagem do quadro (d) para o quadro (e) demonstra uma ação de retirar o 'nariz de palhaço' e segurá-lo na mão. Em seguida, o |narrador| endireita o corpo (quadro (e)) e, olhando para a mão direita, que agora representa iconicamente a ação de segurar o |nariz de palhaço|, aponta para ela com a mão esquerda e, levantando as sobrancelhas e sorrindo, faz uma expressão de quem se lembra de algo. Na sequência, nos quadros (g), (h) e (i), o |narrador| anuncia, realizando os sinais PESSOA e PALHAÇO, que o |nariz de palhaço| é, na verdade, um palhaço; no quadro (i), virando o corpo para a esquerda e direcionando o olhar para cima, o |narrador|, por meio de uma integração conceitual, se torna o |nariz de palhaço/palhaço| enquanto realiza, com a mão direita um emblema que significa 'tudo bem' ou 'positivo', balança o corpo alegremente e, sorrindo, demonstra a ação do |nariz de palhaço/palhaço|, animado, concordando com o juiz|. Nesse momento, o |narrador| revela que é com esse |nariz de palhaço/palhaço| que os |jogadores| vão disputar; o |nariz de palhaço/palhaço| vai servir, nessa partida, como |bolinha| para o jogo acontecer. Nessa demonstração, assumindo a |posição de visualização| do |nariz de palhaço/palhaço/bolinha|, localizada na mão do |juiz|, o |narrador| demonstra a ação da |bolinha| olhando para cima (i.e. para o |juiz|), de uma |posição de visualização| de quem está próximo ao juiz|, na mão dele.

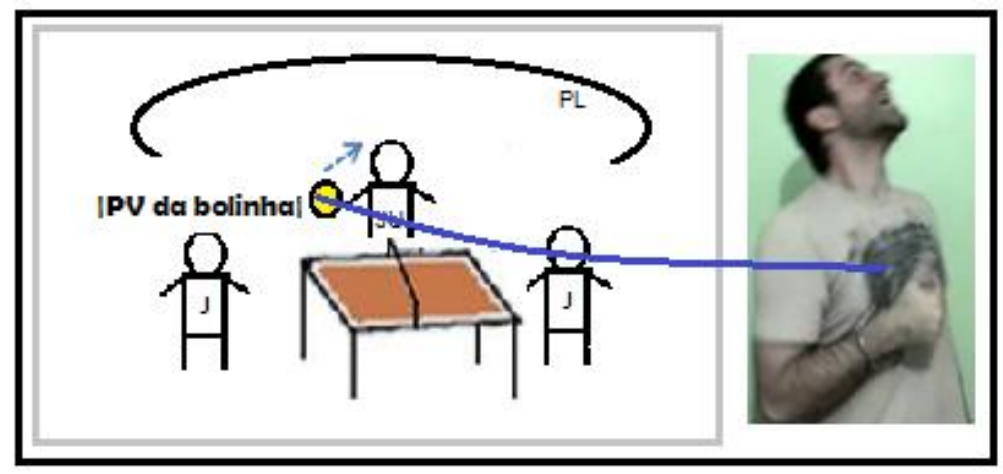

Figura 48 - Posição de visualização da |bolinha|, interna ao |cenário| de escala de dimensão real, olhando para o |juiz| 
Em seguida, virando o corpo para a direita e direcionando o olhar para baixo, o |narrador| demonstra a ação do |juiz|, que, sorri e olha para a |bolinha| na sua mão.

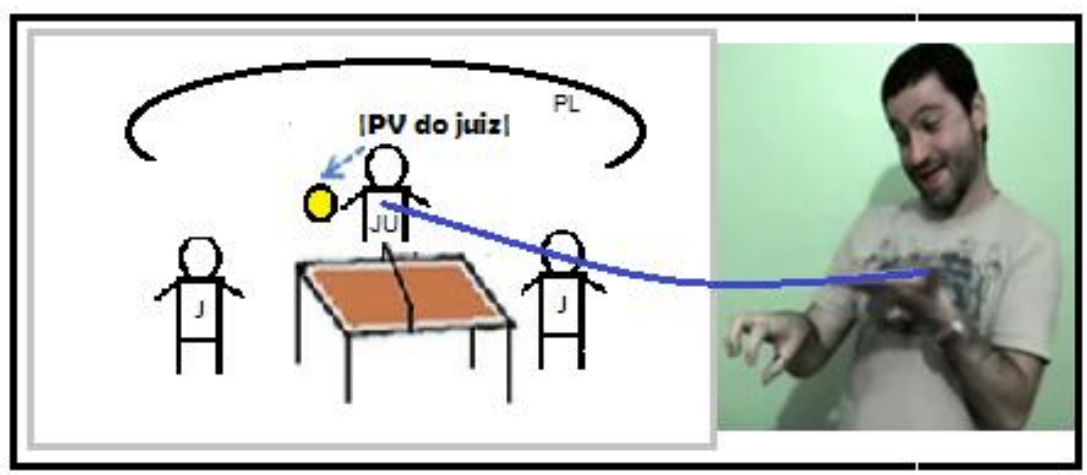

Figura 49 - Posição de visualização do |juiz|, interna ao |cenário| de escala de dimensão real, olhando para a |bolinha| na sua mão

No trecho da Figura 50, abaixo, o juiz| conversa com a |bolinha| e diz que ela será inicialmente do jogador barbudo|. O enunciado da fala do |juiz| poderia ser traduzido como 'agora você [a bolinha] é dele [do jogador barbudo]'. Acontece, portanto, um diálogo (o primeiro discurso direto da história) entre o juiz| e a |bolinha|: essa é a primeira vez que o |narrador| dá voz a uma personagem. O diálogo segue do trecho da Figura 50 até a Figura 52.

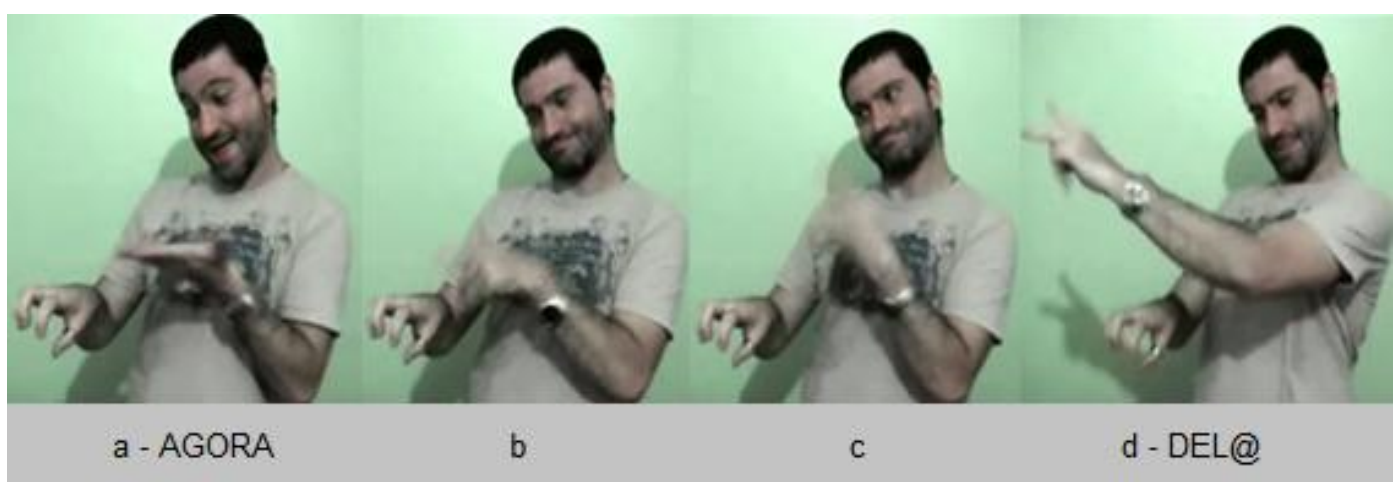

Figura 50 - Demonstração da fala do |juiz|- $\underline{\text { Trecho } 24}$

Como pode ser visto na figura acima, o juiz|, sorrindo, diz AGORA e, depois, como a mão configurada como no sinal DELE, toca a mão direita com a ponta do dedo médio, e, em seguida, realiza um movimento direcional para o jjogador barbudo|. 
A expressão facial do |juiz|, contudo, já não é séria, como era desde o início. Uma maneira de explicar essa mudança na expressão facial séria do jjuiz| é o fato de que o juiz|, uma vez que a |bolinha| está sempre disposta a concordar com ele, parece ser simpático à |bolinha|.

Na sequência, há a demonstração da fala da |bolinha| e, em seguida, do jjogador barbudo|. A sequência de fotos da Figura 51 a seguir, apresenta a demonstração da fala da |bolinha|.

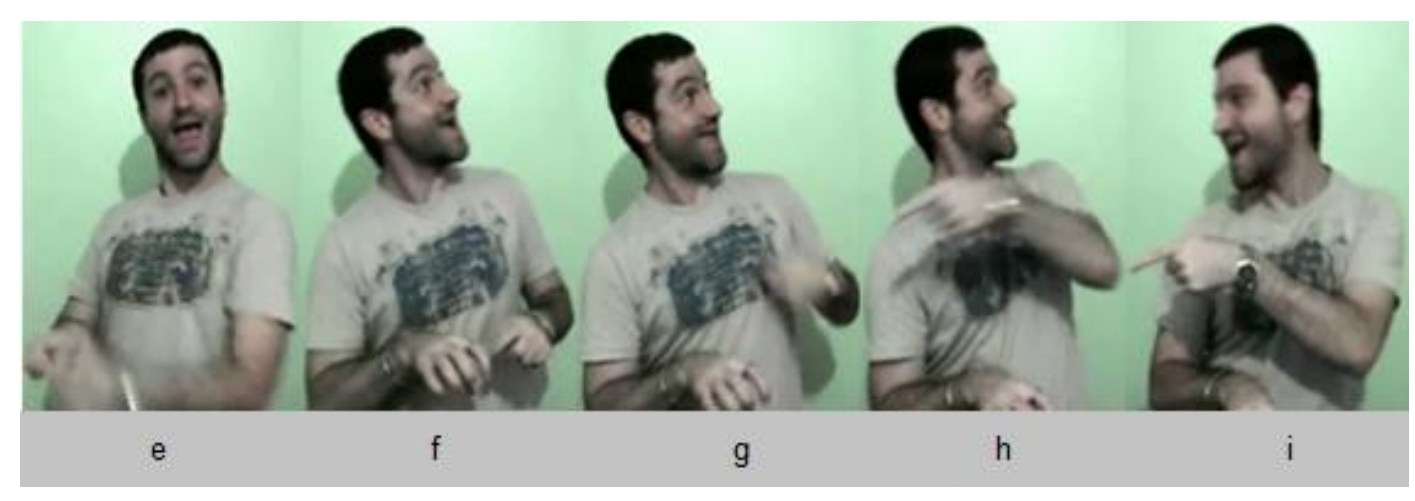

Figura 51 - Demonstração da fala da |bolinha| - $\underline{\text { Trecho } 25}$

$\mathrm{Na}$ sequência de fotos acima, o |narrador| vira o corpo para a esquerda e, direcionando o olhar para cima, demonstra a |bolinha| olhando para o juiz|. Nesse momento, o corpo está partido: enquanto, no quadro (f), a mão direita é entendida como sendo a mão do |juiz|, que segura a |bolinha|, todo o torso do |narrador| virado para a esquerda é assim posicionado para fazer referência à |bolinha|. A bolinha é representada, portanto, em duas demonstrações simultâneas: na mão do jjuiz|, ela é um elemento invisível da demonstração; simultaneamente, ela aparece como |personagem| da história, desta vez visível, e representada em escala de tamanho 'ampliado', pois, se a |bolinha| está na mão do jjuiz|, o seu tamanho 'real' não corresponde ao tamanho do corpo do |narrador|, que, nesse momento, é usado para representá-la. No quadro (f), enquanto a mão direita representa iconicamente a mão do |juiz| segurando a bolinha, o |narrador| aponta, com a mão esquerda, para a mão direita para indicar que é a |bolinha| quem vai falar; no quadro (g), é a |bolinha| quem aponta com a mão direita para o peito para se referir a si mesma; o apontamento com a mão esquerda, no quadro (h), também é da 
|bolinha|, que pergunta ao juiz| se é com o jjogador barbudo| que ela irá para começar o jogo.

Na sequência, como ilustram os quadros (c) até (e) da Figura 52 abaixo, o jjogador barbudo|, com um sorriso perverso, a sobrancelha franzida, vira o corpo para a esquerda, o rosto e o olhar para o mesmo lado e realiza uma sequência de sinais/gestos que podem ser traduzidos como 'essa bolinha é minha'.

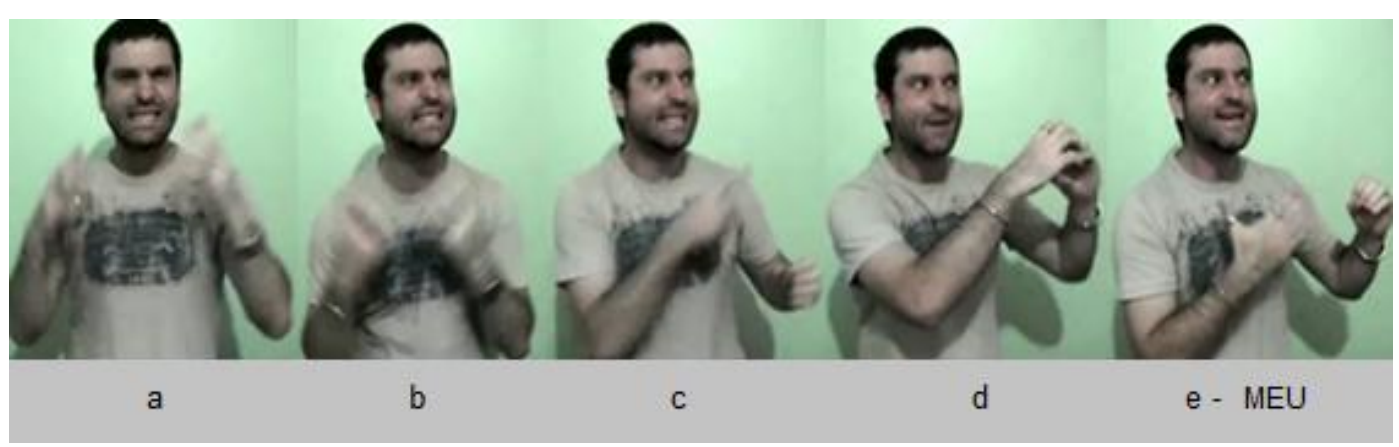

Figura 52 - Demonstração da fala do |jogador barbudo | - Trecho 26

No quadro (a), o |narrador|, enquanto olha para a câmera, exibe a expressão facial que caracteriza o jogador barbudo| e, simultaneamente, realiza o gesto icônico que significa 'barba', com um movimento rápido e muito menos expandido do que nas realizações anteriores usadas para caracterizar o jjogador barbudo|. Realizando esse gesto e virando a cabeça para a esquerda (quadro b), o |narrador| passa a demonstrar a ação do |jogador barbudo|, que começa a falar com o |juiz|. Primeiramente, o |jogador barbudo| aponta para a esquerda (quadro (c)) e, realizando o gesto de 'bola' com as duas mãos (quadro (d)), mantém, em seguida, a mão esquerda realizando o gesto de 'bolinha' e, com a mão direita, sinaliza MEU, tocando o peito.

Em seguida, dos quadros (f) até (i) da Figura 53 abaixo, o |narrador| diz que a |bolinha| é do |jogador barbudo|. 


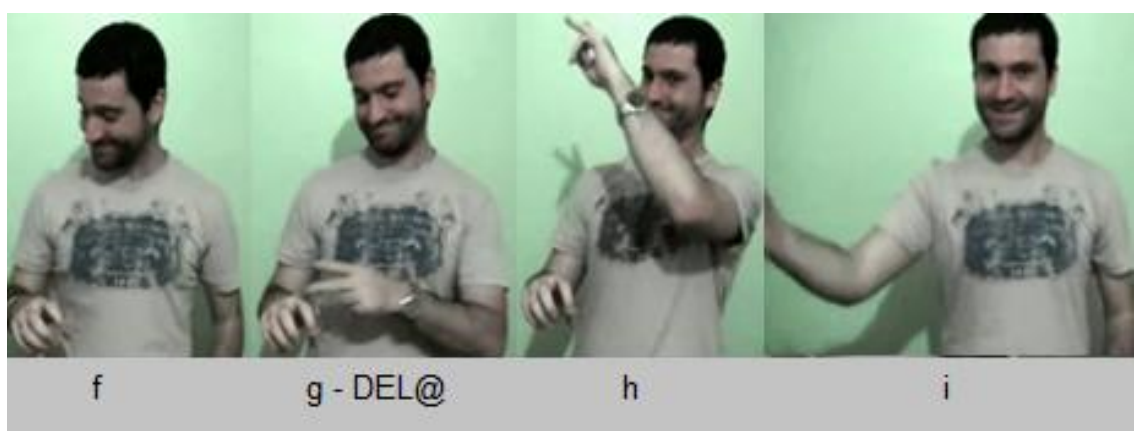

Figura 53 - Conclusão do |narrador| sobre com quem a |bolinha| vai para começar o jogo - Trecho 27

O olhar do |narrador| para a câmera nesse momento (quadros (h) e (i)) parece indicar que ele conclui, para o |narratário|, o resultado da discussão entre o juiz|, a |bolinha| e o jogador barbudo|, de que a |bolinha| vai começar mesmo com o jjogador barbudo|: no quadro (f), o olhar está direcionado para a mão direita. No quadro (g), o |narrador|, realiza o sinal DELE com a mão esquerda, tocando, com o dedo médio as costas da mão direita, que representa a mão do |juiz| segurando a |bolinha|; em seguida, o |narrador| realiza um movimento com a mão esquerda em direção à região onde está o |jogador barbudo|: nessa sequência, o |narrador| está dizendo que a |bolinha|, que está naquela mão, é do jogador barbudo|. Observe-se que o |narrador|, sorrindo, olha para a câmera e demonstra a ação de entregar a |bolinha| para o |jogador barbudo|.

A fala, as ações e as expressões faciais do |juiz| - que pega a |bolinha| para começar o jogo e conversa com ela - e do |narrador| - que apresenta a |bolinha| e conclui com que a |bolinha| vai para começar o |jogo $\mid$ - se assemelham de tal maneira que quase se perde a distinção entre quem é o |narrador| e quem é o juiz| nesse trecho da narrativa.

\section{Primeiro lance}

Tendo apresentado a última personagem da narrativa, o |narrador| passa, então, a apresentar a partida, propriamente dita. A Figura 54 abaixo mostra o momento em que o |jogador barbudo| pega a |bolinha| da mão do |juiz|, o juiz| faz um gesto para que o |jogador barbudo| lance a |bolinha| e o |jogador barbudo| aceita, lançando-a. 

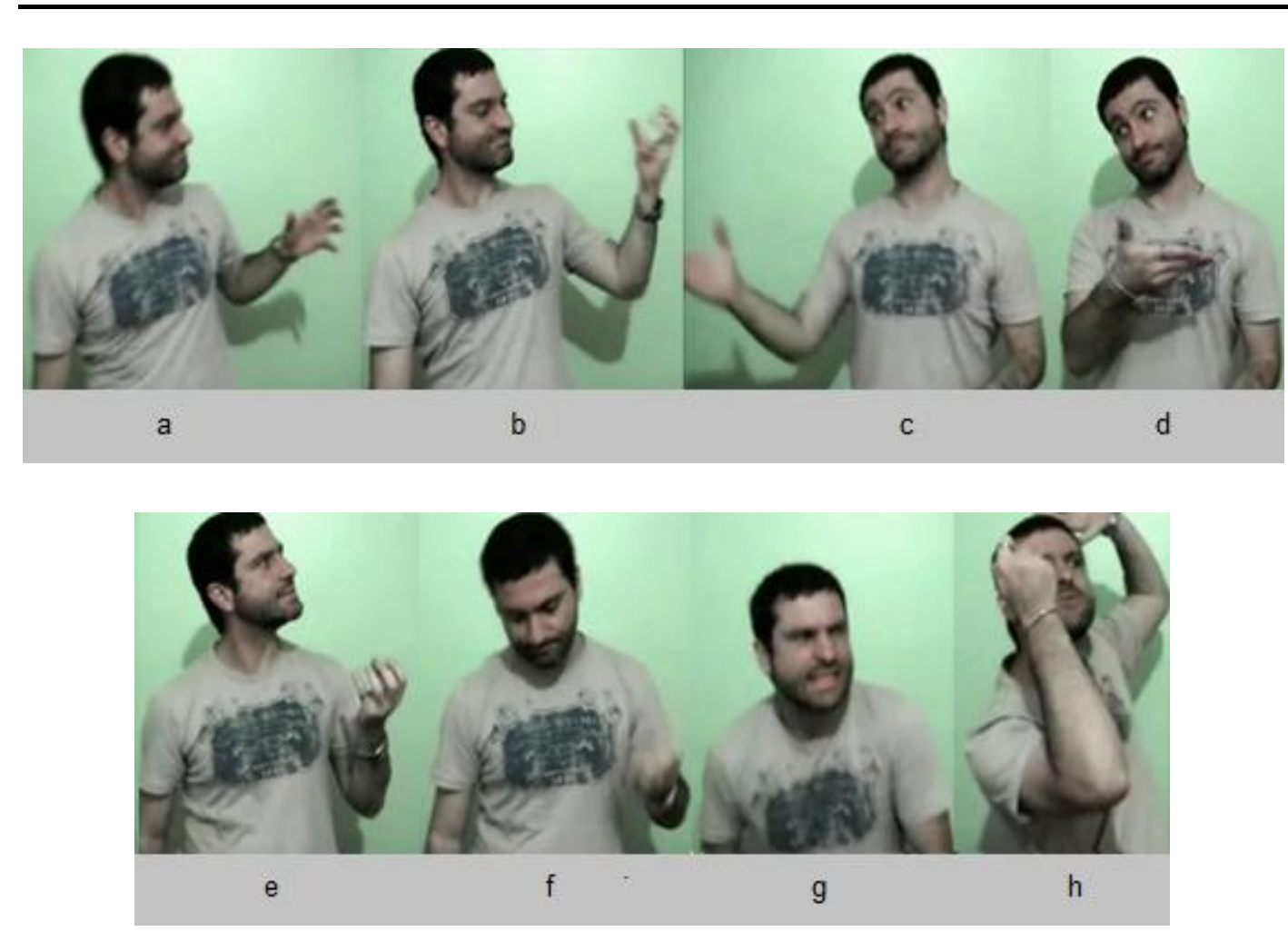

Figura 54 - Demonstração do |juiz| ordenando o início do jogo e do |jogador barbudo| lançando a | bolinha | - Trecho 28

Nos quadros (a) e (b) acima, há a demonstração do jjogador barbudo| pegando a |bolinha| que o juiz| lhe entregou; nesse momento, observa-se que a expressão facial do |jogador barbudo| é de satisfação, especialmente por causa do sorriso que ele apresenta. Nos quadros (c) e (d), há a demonstração da ação do juiz|, que, já não mais sorrindo, olha para o jjogador barbudo| à direita e faz um gesto manual com a mão direita, que é uma indicação para que o jjogador barbudo| lance a |bolinha|. No quadro (e), o jjogador barbudo|, pensativo por um instante, decide, no quadro (f), iniciar a partida. Nesse momento, o jjogador barbudo| faz um aceno com a cabeça, olhando para baixo, como quem se concentra para executar uma tarefa. Embora a foto não capture a ação, no momento que corresponde ao quadro (f), o jogador barbudo| ainda bate a |bolinha| algumas vezes na $\mid$ mesa|, com o corpo virado para frente.

Em seguida, fazendo um impulso com o corpo e movendo-o para baixo (quadro (g)), o jogador barbudo|, finalmente, lança a |bolinha| para a esquerda: com a mão direita vertical fechada (em A), palma pra cima, o |narrador| faz um movimento que se inicia à 
altura do ombro direito, faz uma trajetória circular até a mão alcançar novamente a posição inicial do movimento, à altura do ombro; como pode ser visto no quadro (h) da figura acima, a mão esquerda, durante o movimento da mão direita, também é impulsionada para cima, demonstrando o impulso corporal do |jogador barbudo| que, para lançar a bolinha, move todo o corpo, lançando a |bolinha| com toda a força. Enquanto o |jogador barbudo| bate a |bolinha| na |mesa| e se abaixa para impulsionar o corpo, o olhar está direcionado para a câmera (esse direcionamento do olhar não é capturado na foto; ver $\underline{\text { Trecho 28) }}$. No momento em que o |narrador| demonstra o impacto da |raquete| na |bolinha|, ele também faz uma demonstração vocal do barulho produzido nesse impacto. Esse som vocal, semelhante a uma oclusiva, pronunciada com som forte, demonstra o som da batida da |raquete| na |bolinha|.

\section{Ação inesperada: o jogador delicado sequra a bolinha com a mão}

Na sequência, o |narrador| diz que a |bolinha| passou de um lado a outro da |mesa|, e demonstra que o |jogador delicado|, em vez de rebatê-la, segurou a |bolinha| na mão, como ilustra a Figura 55 a seguir.

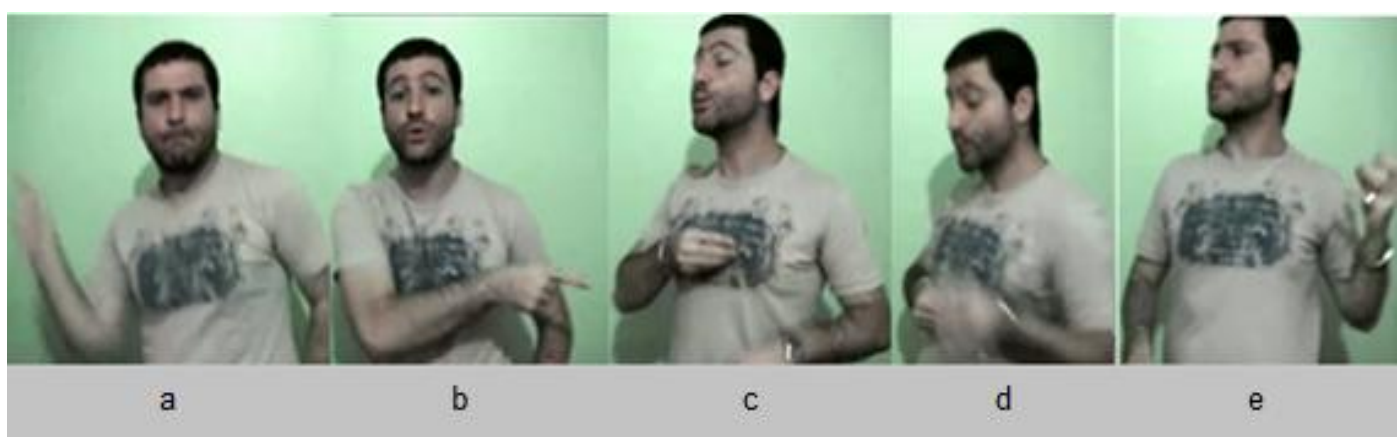

Figura 55 - 0 |jogador delicado| segura

a |bolinha| na mão - Trecho 29

No quadro (a), o |narrador|, olhando para a câmera, usa um gesto manual para representar o percurso da |bolinha| de um lado ao outro, batendo na |mesa de pingue pongue| duas vezes (movimento não capturado na foto; ver Trecho 29): com a mão direita fechada e o dedo indicador distendido, o |narrador| indica, desenhando o trajeto, o movimento que a bolinha fez; simultaneamente, o |narrador| faz dois sons vocais 
sucessivos, simultâneos ao momento em que a mão direita desce, durante o trajeto traçado pela mão no movimento da |bolinha|, batendo na |mesa de pingue pongue|. Os sons vocais demonstram o barulho que a |bolinha| fez ao bater na |mesa de pingue pongue|. Como já foi dito anteriormente, ainda que a |mesa de pingue pongue| não seja um elemento visível da demonstração, uma vez que acompanhamos o mapeamento conceitual da elaboração do cenário imaginário, sabemos que ela está presente à frente do jogador barbudo|.

Em seguida, o |narrador| aponta para a esquerda (quadro (b)) para a região onde está o jogador delicado|. Note-se que, nesse momento, a expressão facial do |narrador| começa já se modificar para representar as expressões do |jogador delicado|: ele ergue as sobrancelhas e deixa os lábios ligeiramente arredondados. Fechando os olhos por um momento (quadro (c)), abrindo-os em seguida e direcionando o olhar para baixo (quadro (d)), o |narrador| demonstra a ação do |jogador delicado|, de pegar a bolinha rapidamente com a mão esquerda; embora a figura (e) não capture os detalhes da demonstração, nesse momento, o |jogador delicado| segura a |bolinha| com a mão esquerda.

Na sequência, o |narrador| demonstra a ação dos demais |participantes|, que ficam atônitos com a atitude do |jogador delicado|; em seguida, ele realiza uma nova demonstração da ação do |jogador delicado| de pegar a |bolinha|.

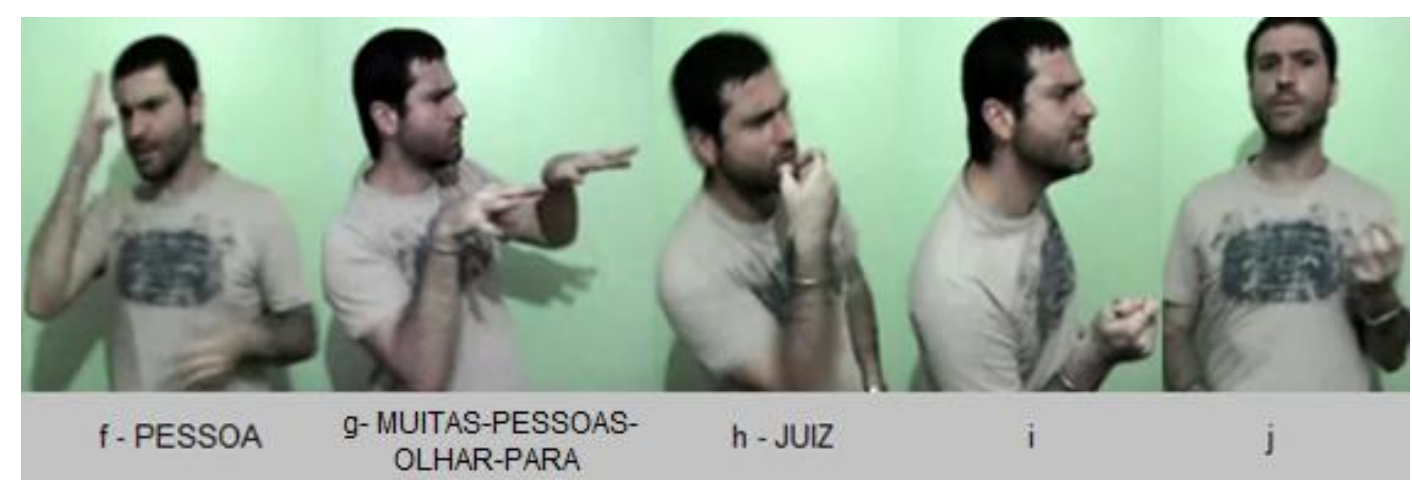

Figura 56 - Demonstração das |personagens| da história olhando para o |jogador delicado| atônitas - Trecho 30

No quadro (f), o narrador| usa o sinal PESSOA e, em seguida, um sinal direcional MUITAS-PESSOAS-OLHAR-PARA (quadro (g)), movendo o corpo rapidamente para 
a esquerda. ${ }^{61}$ Depois, enquanto realiza o sinal JUIZ, o |narrador| inclina ainda mais o corpo para a esquerda, demonstrando a ação do juiz| (quadro (h)). No quadro (i), o |narrador| assume a postura do |jogador barbudo| segurando a |raquete|, e também vira o corpo bruscamente para a esquerda, demonstrando a ação dessa personagem. Por fim, o |narrador| demonstra novamente a ação do jogador delicado| pegando a bolinha (quadro (j)). Aqui há um ponto interessante a considerar, do ponto de vista da organização temporal da narrativa: quando o |narrador| demonstra a ação do jogador delicado| pela segunda vez, ele não pretende mostrar que o jogador delicado| pegou a |bolinha| duas vezes, mas que se trata da mesma ação sendo mencionada novamente. A demonstração constrói visualmente a cena: o |narrador| já havia demonstrado o |jogador delicado| pegando a $\mid$ bolinha| com a mão; mas, como só é possível demonstrar uma ação de |personagem| por vez, o |narrador| "corta a cena" para mostrar a reação dos demais |participantes| em relação à atitude do jogador delicado| no exato momento em que o |jogador delicado| pegou a |bolinha|; é como se a câmera passasse por cada uma das personagens - a |plateia|, o |juiz| e o jjogador barbudo| - e observasse as suas reações naquele exato momento.

Depois desse 'corte', o |narrador| retoma, muito rapidamente, a ação do jjogador delicado|, de segurar a |bolinha|; o quadro em (j) captura o momento final da ação, em que o jjogador delicado| segura a |bolinha| e mantém-na próxima ao corpo, como se não quisesse devolvê-la.

\section{Reinício do jogo: ações dos jogadores}

Na sequência, o juiz| repreende o jjogador delicado| com um aceno de cabeça negativo e faz um gesto para que ele retome o jogo. O jogador delicado|, com uma expressão facial contrariada, aceita, como mostra a sequência a seguir.

\footnotetext{
${ }^{61}$ Os verbos direcionais são aqueles que se caracterizam por realizar movimento direcional no espaço de sinalização. No verbo direcional MUITAS-PESSOAS-OLHAR-PARA, os dedos apontam para a região para onde o olhar é direcionado. Para uma descrição dos verbos direcionais indicadores em libras, ver Moreira (2007).
} 


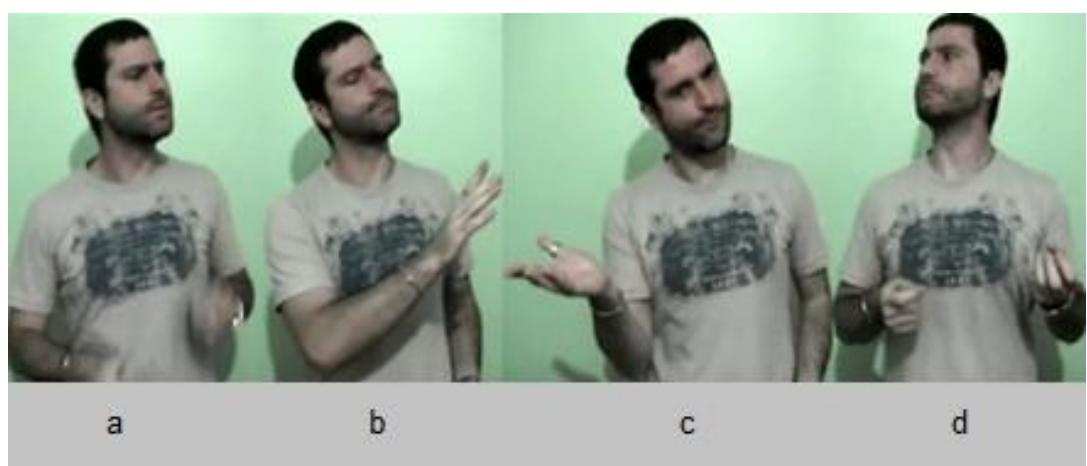

Figura 57 - Demonstração do |juiz| ordenando o reinício da partida - Trecho 31

No quadro (a), o |narrador| demonstra a ação do juiz| que, posicionado ao centro, olha para o jogador |delicado| à esquerda e com a sobrancelha franzida (quadros (a) e (b)) reprova a atitude do |jogador delicado|, com um movimento de cabeça negativo. O |juiz| faz dois acenos com a mão direita: o primeiro aceno é um emblema que significa 'pare' ou 'espere' (quadro (b)) e o segundo é uma indicação para que o jogador delicado| lance a |bolinha| para a direita; nesse momento o |narrador| olha para a câmera, como pode ser visto no quadro (c). O jogador delicado| para por um momento, segurando a |bolinha|, com uma postura hesitante (quadro (d)). Na sequência, como ilustra a Figura 58 a seguir, o jogador delicado aceita e, depois de bater a |bolinha| na mesa algumas vezes, a lança.

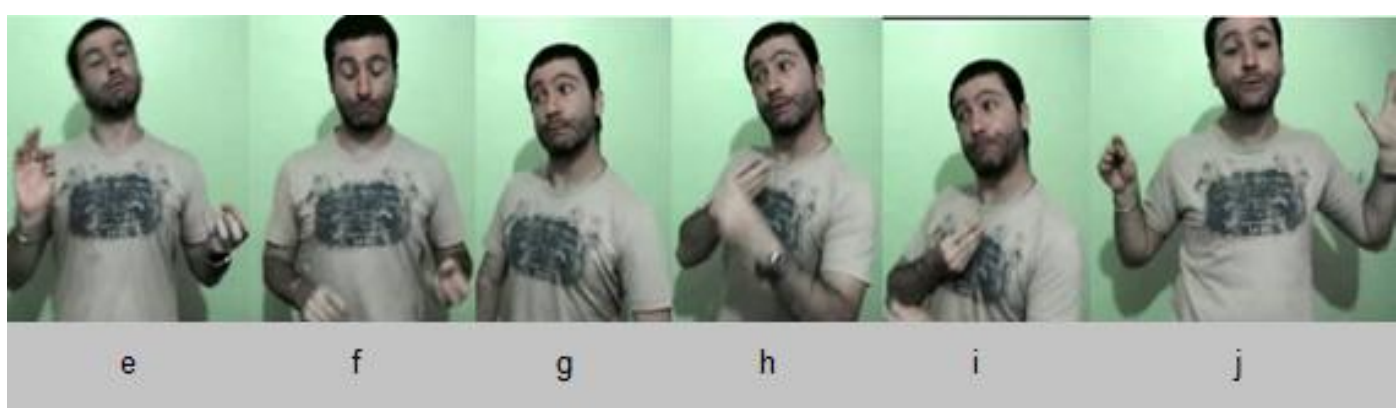

Figura 58 - Demonstração do |jogador delicado| lançando a | bolinha - Trecho 32

No quadro (e) acima, o |narrador| demonstra a ação do jjogador delicado|, que, segurando a |raquete| com a mão direita e a |bolinha| com a mão esquerda, faz um 
emblema com a mão direita que significa 'espere'. Note-se que, como o |jogador delicado| está segurando a |raquete|, o emblema é feito com a mão aberta, palma para frente, e os dedos distendidos, mas os dedos indicador e polegar continuam unidos pelas pontas, demonstrando que, enquanto o jogador delicado| faz o gesto manual, ele segura a |raquete| na mão. Nesse momento, o jogador delicado| ainda fecha os olhos e faz um movimento oscilante com o corpo, sugerindo sua hesitação. No quadro (f) da figura acima, o jjogador delicado| olha para baixo, para a |mesa| à sua frente e, depois de bater a |bolinha| na |mesa| algumas vezes, faz o lançamento. A sequência de (g) até (i) mostra o jjogador delicado| se preparando para lançar a |bolinha| e, no quadro (j), ele virando o corpo, depois do impacto de bater com a |bolinha| na |raquete|. Simultaneamente à demonstração do |jogador delicado| batendo a |bolinha| na |mesa| e batendo com a |raquete| na |bolinha|, há a emissão de sons vocais, que demonstram o barulho produzido pelos impactos da |bolinha| com os outros |objetos|.

$\mathrm{Na}$ sequência, o |narrador| demonstra uma sequência de bates-e-rebates da |bolinha| entre os jogadores|, como ilustra a Figura 59 a seguir.
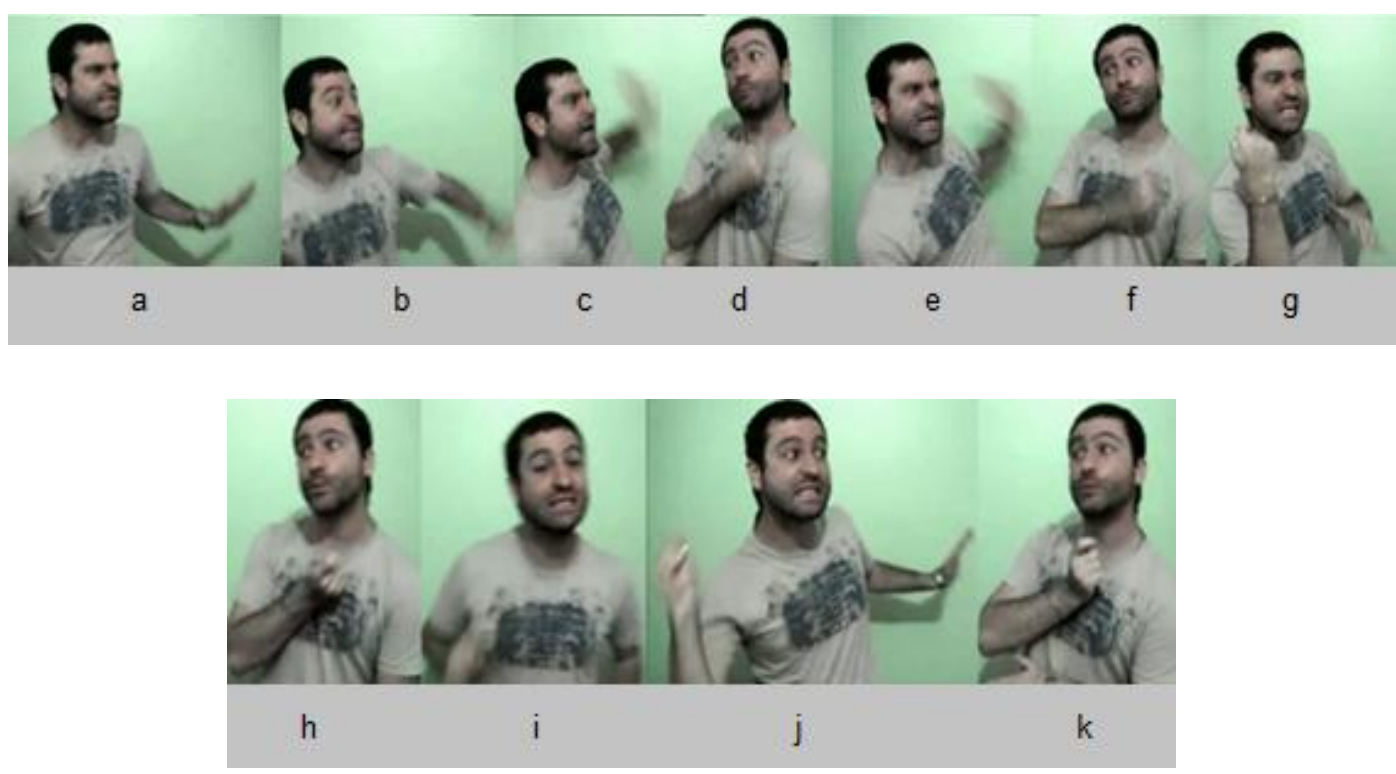

Figura 59 - Demonstração da sequência de bates-e-rebates da | bolinha| - Trecho 33

No quadro (a), o |narrador| demonstra a ação do jogador barbudo| que, depois de o |jogador delicado| haver lançado a |bolinha| na sequência anterior, se prepara para 
rebatê-la. No quadro (b), embora a foto não capture esse movimento, o |narrador| olha para baixo e, com a mão direita, indica o trajeto da |bolinha| que, vindo do outro lado, bate duas vezes na |mesa de pingue pongue| localizada em frente ao ljogador barbudo|; simultaneamente, o |narrador| faz dois sons vocais simultâneos à indicação do trajeto da |bolinha|, que demonstram o som que ela fez ao bater na |mesa|. Em seguida, o |narrador| demonstra o ljogador barbudo| rebatendo a |bolinha| (quadro (c)). Depois disso, o |narrador| realiza uma sequência de demonstrações do bate-e-rebate da bolinha de pingue pongue entre os |jogadores|, todas elas acompanhadas de um som vocal que demonstra o som da |bolinha| batendo na |raquete|. Os quadros (a), (b), (c), (e), (g), (j) são demonstrações de ação do jjogador barbudo| e os quadros (d), (f), (h), (k) são demonstrações de ação do |jogador delicado|.

É interessante observar como o |narrador|atua, nesse momento, como se ele fosse os próprios jogadores| de pingue pongue; algumas das ações, contudo, são entendidas como sendo do nível do |narrador|, outras do nível da |personagem|. Quando observamos a figura acima, vemos que, na realização de demonstração de cada um dos |jogadores|, o |narrador| exibe uma expressão facial diferente, que caracteriza cada uma das personagens: o jogador barbudo| está, na maioria das vezes, com as sobrancelhas franzidas e os dentes à mostra; e o jjogador delicado| está sempre com as sobrancelhas levantadas e uma configuração de lábios arredondados. Se, por um lado, as expressões faciais são das |personagens|, por outro, elas são demonstrações feitas pelo |narrador| para caracterizar as |personagens|. Em certo sentido, essas expressões carregam até mesmo uma avaliação do |narrador|. Também são entendidas como ações dos |jogadores| o movimento do corpo, que se vira para a direita e para a esquerda, acompanhado do direcionamento do olhar para o mesmo lado. Além dessas demonstrações, simultaneamente, há outras demonstrações sendo realizadas, que são aquelas em que o |narrador| produz sons vocais para demonstrar que a |bolinha| se choca contra a |raquete|. Essas demonstrações são entendidas como sendo realizadas no nível do |narrador|: não são as |personagens| que estão fazendo aqueles sons vocais enquanto jogam, mas o |narrador| quem faz os sons, para representar sonoramente as batidas da |bolinha| na |raquete|. 


\section{Movimentos da bolinha no cenário}

Essa sequência de demonstrações de ações de |personagens| atuando no jogo é seguida por outras sequências de demonstrações, que apresentam outros aspectos visuais da história. Na sequência de demonstrações analisada no trecho acima, Figura 59, o único elemento visível é, em cada um dos momentos capturados pelos quadros, um dos |jogadores|, enquanto os demais elementos da demonstração não são visíveis, mas são inferidos pela ação do |narrador| e pelo discurso anterior. Na sequência de ações apresentadas no trecho a seguir, o |narrador|, posicionando o corpo ao centro, usa gestos manuais para representar a $\mid$ bolinha $\mid$ indo de um lado para o outro, como ilustra a Figura 60 a seguir.
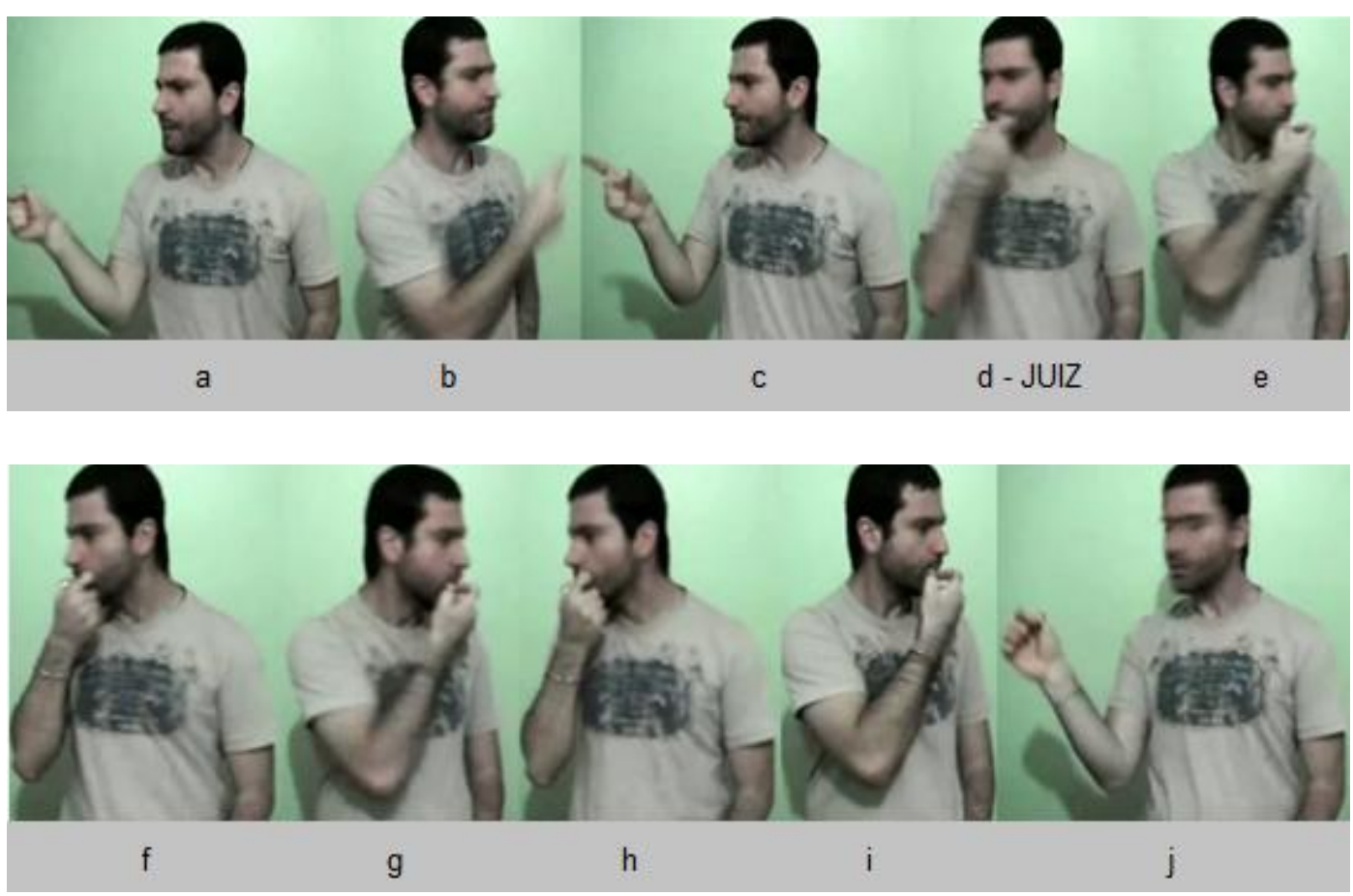

Figura 60 - Demonstrações de movimentos da |bolinha| no |cenário|(I) - Trecho 34

Como mostra a figura acima, nos quadros (a), (b) e (c), o |narrador| indica o movimento da $\mid$ bolinha $\mid$ no |cenário| por meio do apontamento manual realizado pela mão direita. Simultaneamente, o |narrador| acompanha o movimento da |bolinha|, que neste momento é um elemento invisível no |cenário|, virando o torso e a cabeça para a direita, 
para a esquerda e, novamente, para a direita. Em seguida, dos quadros (d) até (i), o |narrador| continua virando o torso e a cabeça para a direita e para a esquerda, mas realiza, ao mesmo tempo, o sinal JUIZ, para dizer que é o jjuiz| quem está olhando para um lado e para o outro, acompanhando o movimento da |bolinha| com o olhar.

Depois disso, o |narrador| interrompe a demonstração de ação do juiz| e realiza uma demonstração com a mão direita, de a |bolinha| estar se movendo de um lado para o outro. Nesse momento, o único elemento do |cenário| que está visível na demonstração é a |bolinha| e os demais elementos são inferidos a partir do seu movimento: sabemos que os |jogadores| continuam batendo e rebatendo a |bolinha| com as suas |raquetes|, mas é o movimento da |bolinha| que está sendo demonstrado no momento e o barulho da |bolinha| se chocando contra as |raquetes|, que é representado por sons vocais que o |narrador| realiza concomitantemente à realização da demonstração manual do movimento da |bolinha|.

A dinamicidade do jogo é expressa na tensão dos gestos, que, ao longo das sequências que são apresentadas a seguir, vai aumentando: as expressões faciais usadas para representar as |personagens| vão ficando mais marcadas, bem como as demonstrações corporais de ações das |personagens| e os gestos manuais usados para representar o movimento da |bolinha| de um lado para o outro no |cenário|. Na Figura 61, a seguir, o narrador| com as sobrancelhas um pouco franzidas, demostra o movimento da |bolinha| no |cenário|.

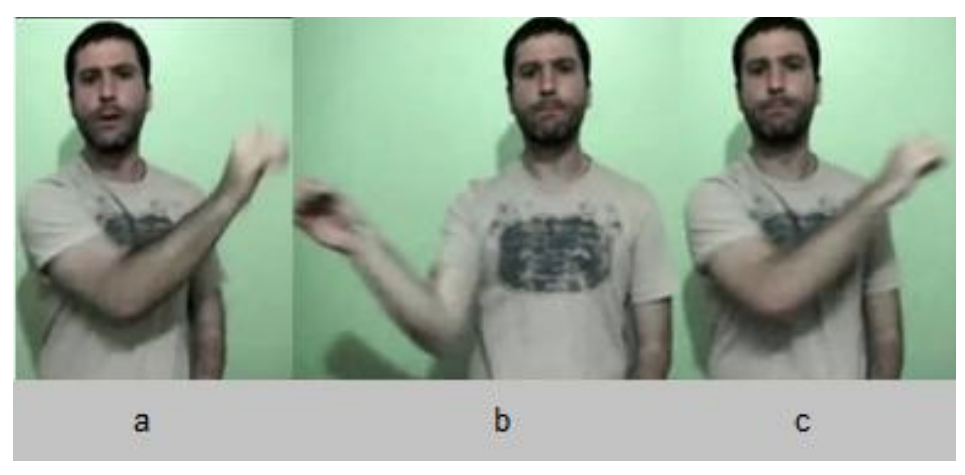

Figura 61 - Demonstrações de movimentos da |bolinha| no |cenário|(II) - Trecho 35

Para falar do movimento da bolinha de um lado para o outro, o |narrador| realiza, com a mão direita, um gesto icônico que significa 'bolinha', movendo a mão para a direita 
e para a esquerda. Simultaneamente, o |narrador| produz sons vocais semelhantes aos que já haviam sido realizados anteriormente para representar o som da |bolinha| se chocando contra as |raquetes|.

Em seguida, o |narrador| realiza a demonstração da ação do |juiz| e, logo em seguida, a demonstração da |plateia| olhando para um lado e para o outro, como ilustra o trecho a seguir, na Figura 62.
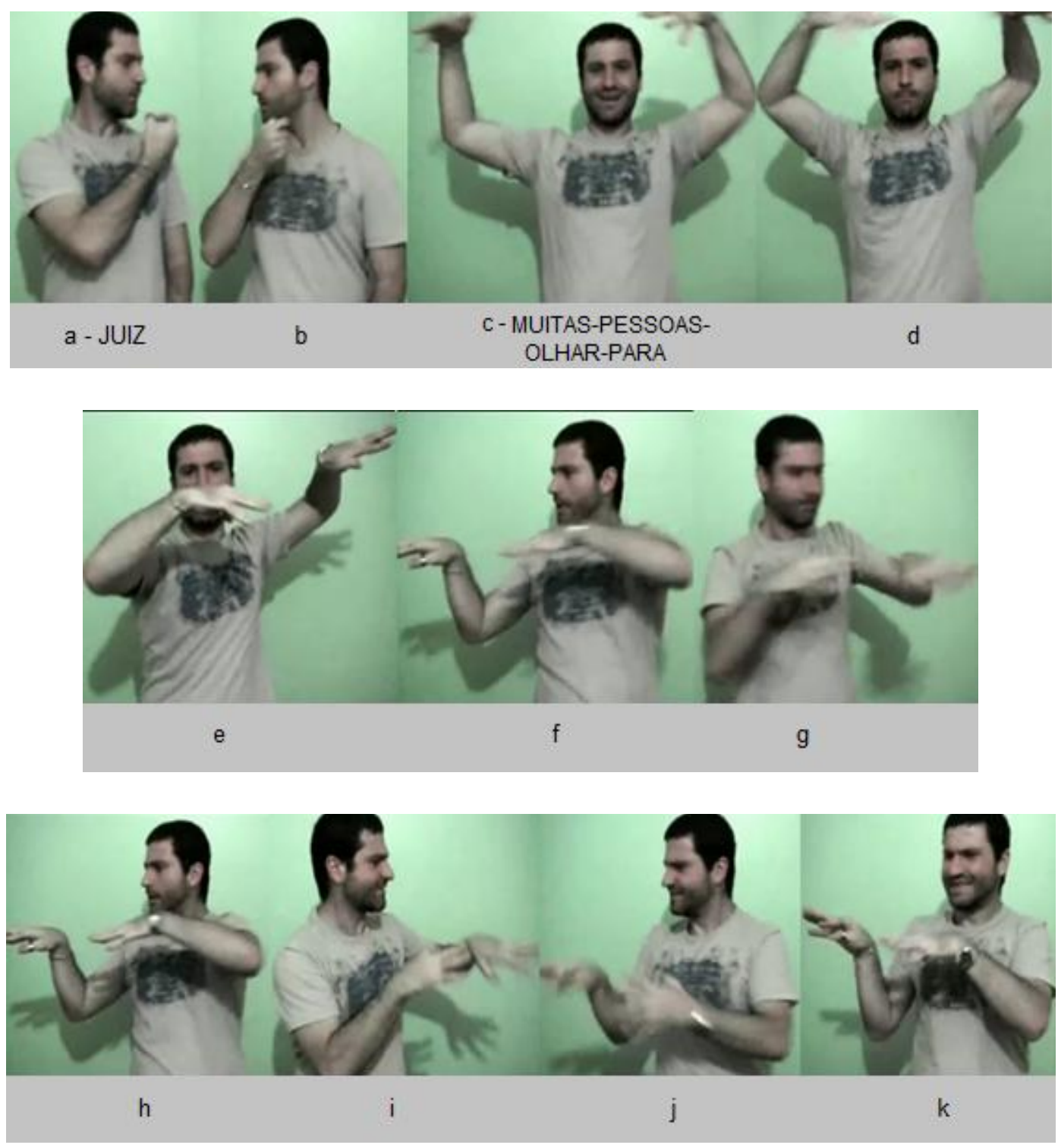

Figura 62 - Demonstração da ação do |juiz| e da |plateia |, acompanhando o movimento da | bolinha| com o olhar - $\underline{\text { Trecho } 36}$ 
Nos quadros (a) e (b), o |narrador| realiza o sinal JUIZ com a mão direita e, simultaneamente, demonstra a ação do |juiz| de olhar para um lado e para o outro, acompanhando, com o olhar, o movimento da |bolinha|. Em seguida, no quadro (c), o |narrador| posiciona as mãos acima da cabeça e realiza, nessa posição, o sinal MUITASPESSOAS-OLHAR-PARA, direcionando esse sinal para a direita e para a esquerda, alternadamente; o movimento desse sinal demonstra o olhar das |pessoas| na plateia, que acompanha o movimento da |bolinha|. A localização da realização do sinal é digna de nota, na medida em que não é a localização prototípica do sinal. O fato de ele ter sido realizado na altura da cabeça do sinalizador significa que a |posição de visualização| da |plateia| é mais alta do que o |local do jogo|.

Entretanto, ao longo da sequência, o |narrador| vai baixando as mãos, de modo que, a partir do quadro (g), as mãos já estão posicionadas à altura do peito; esse abaixamento das mãos pode significar tanto as pessoas sentadas nos lugares mais altos da |plateia|, quanto aquelas que estavam em um nível mais próximo ao |local do jogo| acompanhavam o movimento da |bolinha| com o olhar, como pode significar simplesmente que o |narrador|, uma vez que já apresentou a localização da |plateia|, decide posicionar as mãos numa localização mais cômoda para movimentá-las.

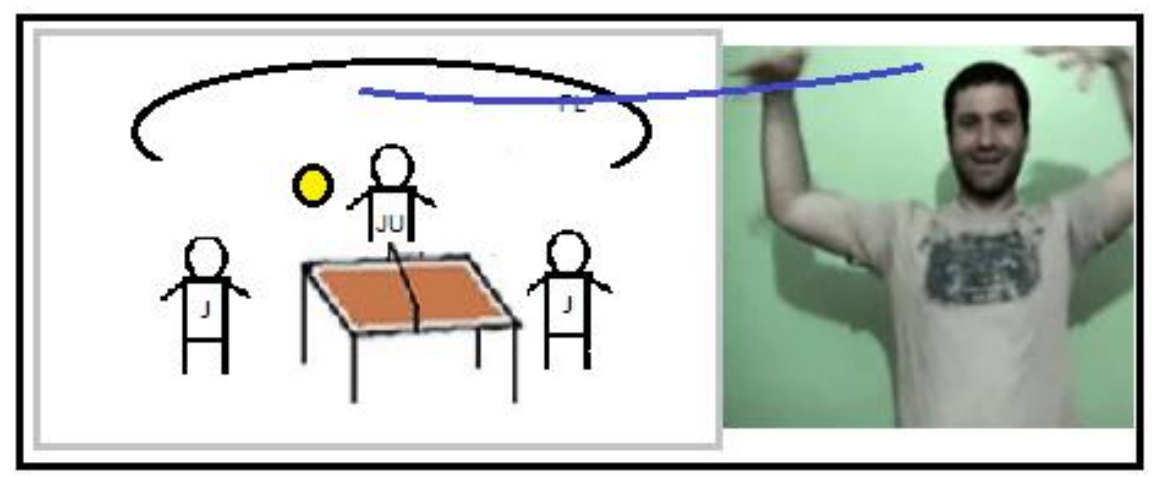

Figura 63 - Posição da |plateia| no |cenário| de escala de dimensão 'real'

No momento em que o |narrador| realiza o sinal MUITAS-PESSOAS-OLHARPARA, ele mostra um sorriso, que pode ser reconhecido como sendo da |plateia|, que assiste animadamente ao jogo; entretanto, o sorriso dura só um momento e, em seguida, o |narrador| muda a expressão de um sorriso para uma expressão séria, que vai ficando cada vez mais tensionada. Note-se nessa sequência que a tensão na expressão facial já 
começa a ficar bastante marcada na passagem do quadro (h) para o quadro (i). Esse aumento da tensão facial e, mais adiante, da tensão do movimento dos gestos manuais e das ações corporais, serve para demonstrar que a partida vai se tornando mais acirrada a cada momento. Durante a realização desse sinal, o |narrador| realiza gestos vocais simultâneos para demonstrar que a |bolinha| está se chocando contra as |raquetes|.

A sequência seguinte de demonstrações alterna demonstrações manuais e demonstrações que envolvem todo o corpo: na figura abaixo, o |narrador| demonstra, com um gesto manual, a |bolinha| se movendo de um lado para o outro. Simultaneamente, os sons vocais expressam que a |bolinha| se choca contra as |raquetes| e a expressão facial do |narrador|, tensionada, expressa a tensão envolvida no jogo. Essa sequência é muito semelhante àquela apresentada na Figura 61, anteriormente discutida; a diferença está no fato de que, na sequência atual, o |narrador| emprega mais tensão, tanto no movimento da mão que representa o movimento da |bolinha|, quanto na expressão facial.

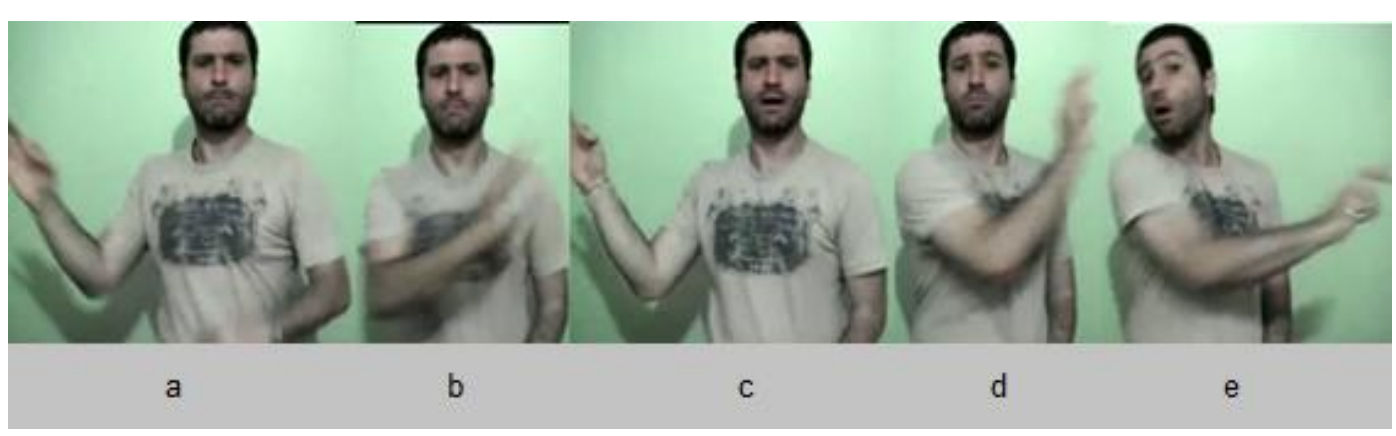

Figura 64 - Demonstrações de movimentos da |bolinha| no |cenário|(III) Trecho 37

Ações dos jogadores e movimentos da bolinha no cenário: 'câmera lenta'

A sequência na Figura 65 a seguir mostra o |narrador| demonstrando, com gestos manuais, a |raquete| rebatendo a |bolinha| várias vezes: 

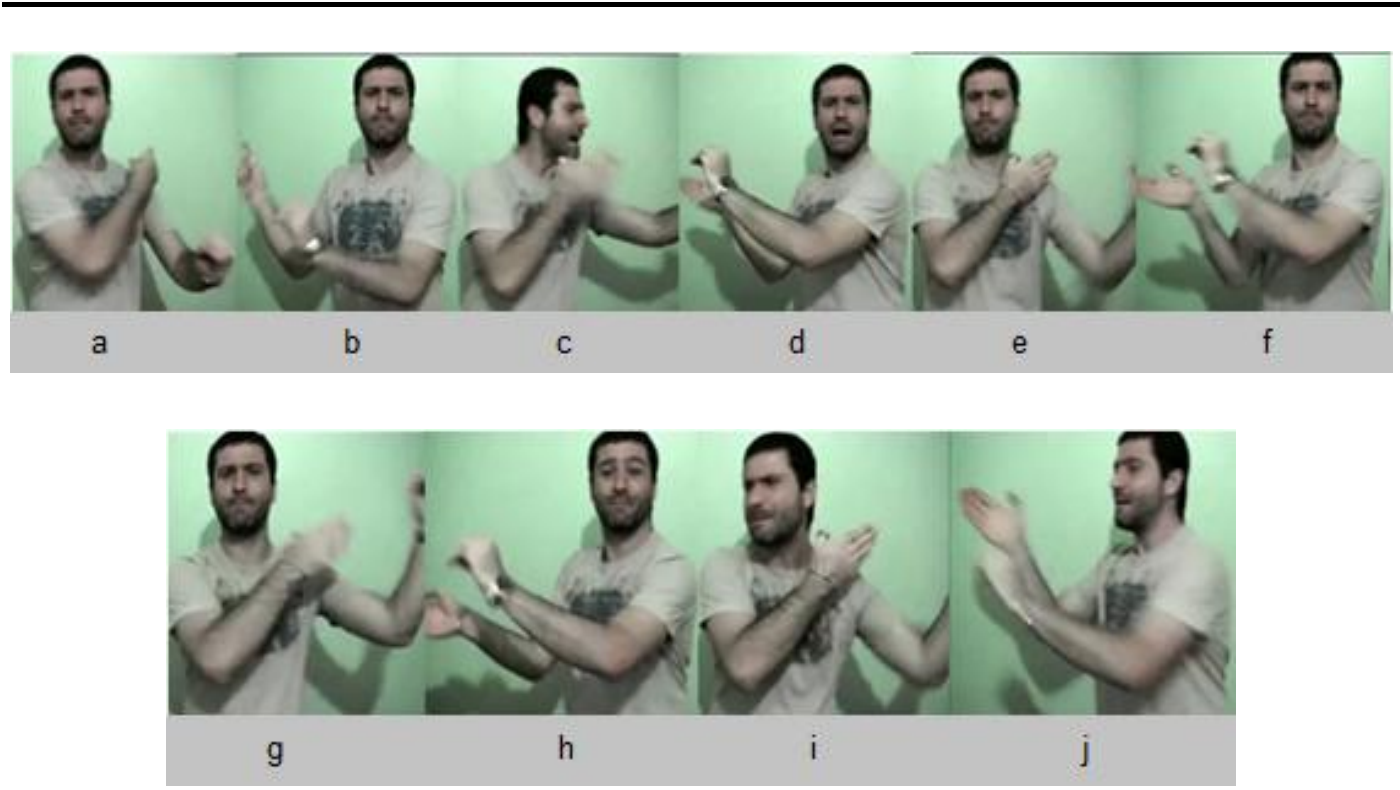

Figura 65 - Demonstração da | raquete | batendo na |bolinha| - Trecho 38

No quadro (a), com a mão direita aberta representando iconicamente a |raquete| e a mão esquerda, com os dedos unidos pelas pontas, representando iconicamente a |bolinha|, o |narrador| bate a palma e as costas da mão direita na mão esquerda por várias vezes, movendo ambas as mãos sequencialmente para a direita e para a esquerda.

Em seguida, o |narrador| inicia uma nova sequência de demonstrações de ações das |personagens|. Dessa vez, essa sequência de demonstrações de ação é realizada em uma velocidade menor que as ocorrências anteriores, sugerindo uma filmagem em câmera lenta.

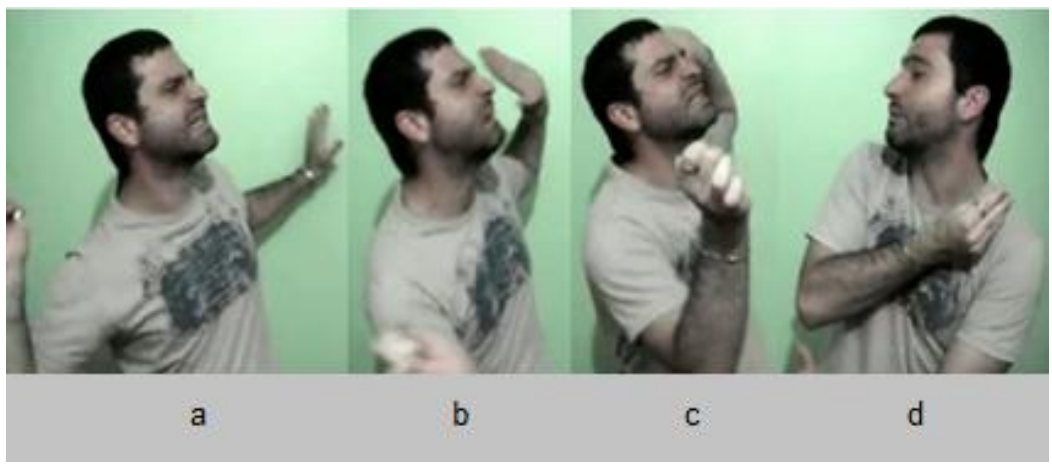




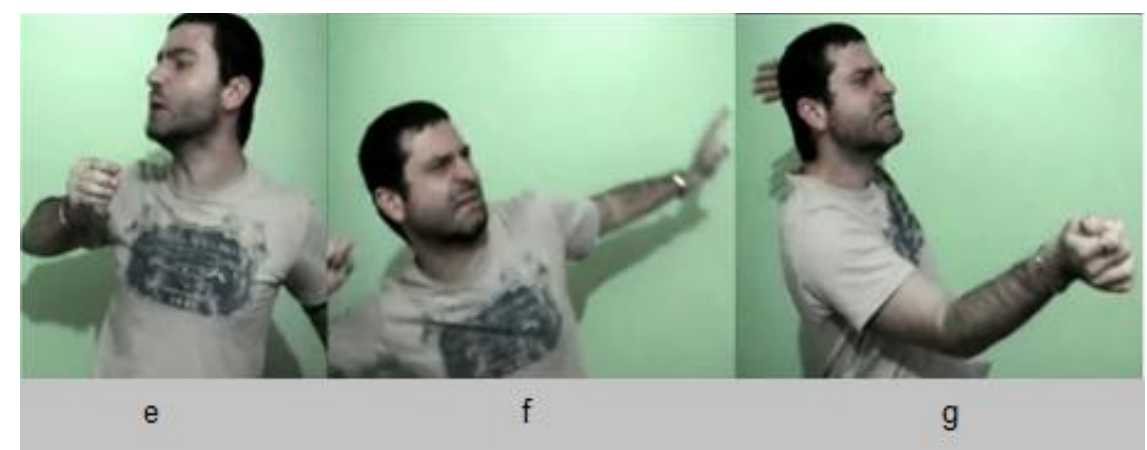

Figura 66 - Demonstração da ação das |personagens | em velocidade reduzida, sugerindo uma filmagem em câmera lenta - Trecho 39

$\mathrm{Na}$ demonstração de ação das |personagens| em velocidade reduzida é preciso entender que a temporalidade do evento permanece inalterada, enquanto a temporalidade da narração é reduzida. Por isso, para entender essa sequência de demonstrações corretamente, é preciso entender que não são os |jogadores| que estão agindo lentamente, mas o |narrador| que, podendo alterar a temporalidade da narração, age mais lentamente, dando a ideia de que a cena é vista em câmera lenta.

Continuando a demonstração de ações das |personagens| em velocidade reduzida, o |narrador| passa a usar o corpo, visto na Figura 67 abaixo, para representar agora os movimentos da |bolinha| não mais como um objeto da história, mas como uma |personagem| animada, que sofre ao receber as raquetadas dos |jogadores|.

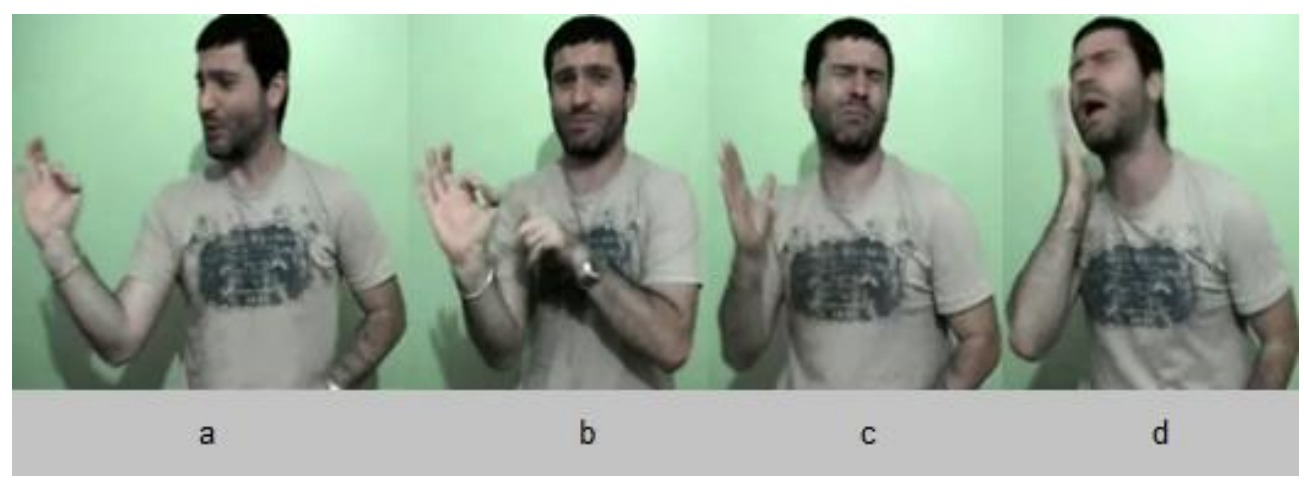




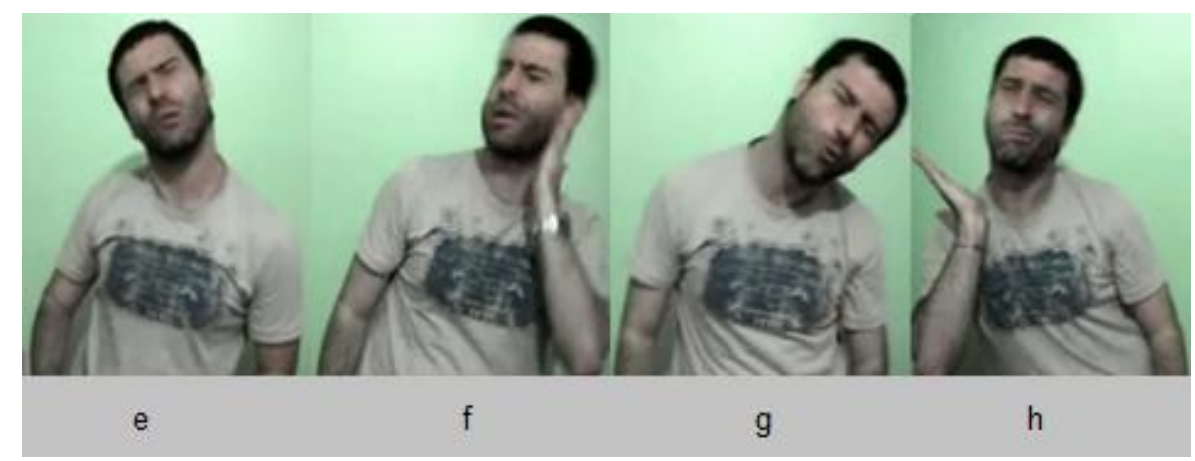

Figura 67 - Demonstração da |bolinha| sendo esbofeteada de um lado para o outro - Trecho 40

Nessa sequência, o |narrador| volta o corpo para a posição central (quadro (a)) e, demonstrando o movimento da |bolinha| por meio do gesto manual icônico realizado pela mão direita, aponta para ela, no quadro (b), com a sua mão esquerda, iniciando, em seguida, uma demonstração de ação em que a |bolinha| é 'esbofeteada' em uma face e noutra (quadro (c)). Nessa demonstração, entende-se que a mão direita representa iconicamente a |raquete| e que o rosto do |narrador| é a |bolinha|; o |narrador|, então, passa a usar o corpo para fazer referência à bolinha: com a mão direita aberta, o |narrador| bate na face direita e move o corpo para a esquerda; quando o corpo está posicionado à esquerda, ele bate com a mão |esquerda| na face esquerda e move o corpo para a direita. Durante a realização dessa demonstração, a |bolinha| mantém os olhos fechados e a expressão facial demonstra dor.

Num dado momento da demonstração, a |bolinha| abre bem a boca, como se estivesse gritando, e também mantém os olhos bem abertos, como se vê na Figura 68 a seguir. 


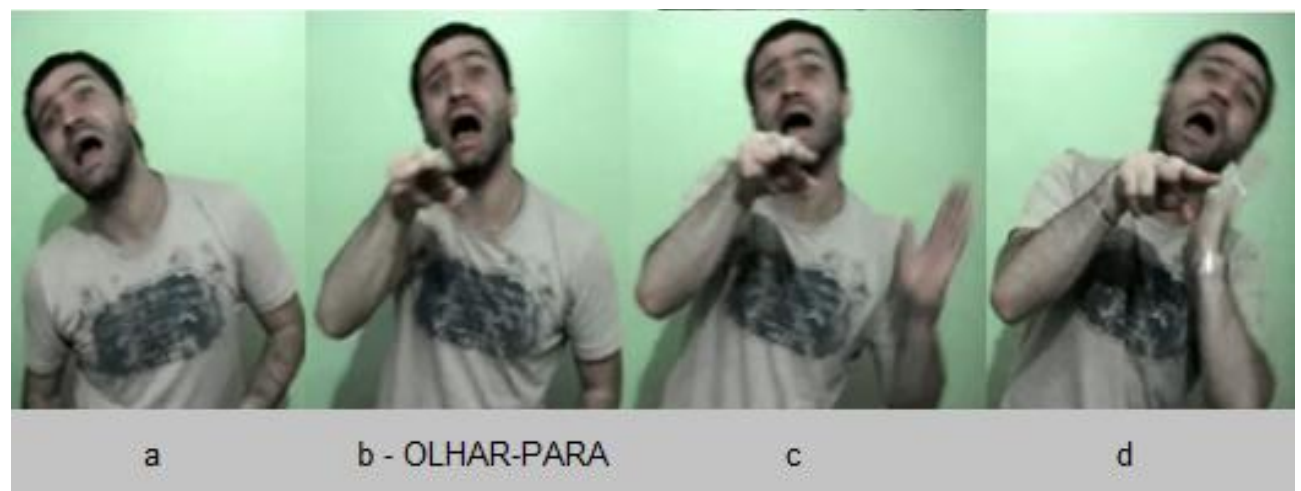

Figura 68 - Demonstração da |bolinha| olhando para o |juiz|, simultânea à demonstração manual, realizada pela fala do narrador - Trecho 41

Na figura acima, enquanto realiza a demonstração da ação da |bolinha| se movendo para a esquerda, o |narrador| libera as mãos para narrar: com a mão direita, o |narrador| sinaliza OLHAR-PARA, direcionado para frente (quadros (b), (c) e (d)); esse sinal é usado pelo |narrador| para descrever, redundantemente, a ação que descreve a ação corporal da |bolinha|, que olha para frente enquanto se move para um lado e para o outro. Observe-se que aqui a cena passa a ser vista da |posição de visualização| da |bolinha|, que, estando de frente para o juiz|, se move de um lado para o outro do |cenário| enquanto olha para ele.

Em seguida, como mostra a Figura 69 abaixo, o |narrador| volta o corpo para o centro e, com uma postura ereta, realiza o sinal JUIZ. A postura e expressão facial do |narrador|, nesse momento, demonstram a ação do jjuiz|, que, com as sobrancelhas curvadas, se mostra um pouco apreensivo.

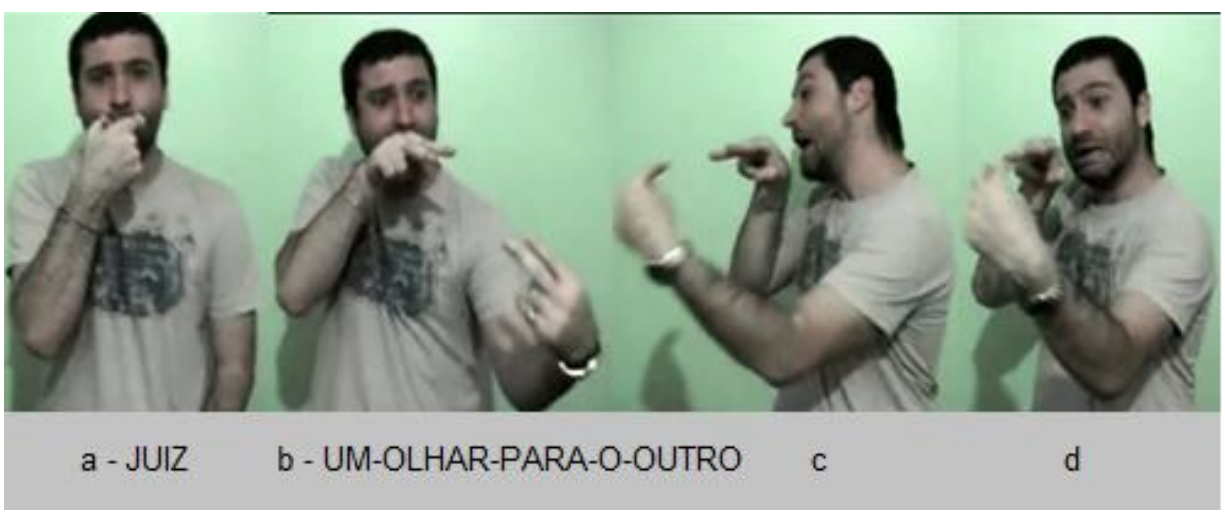




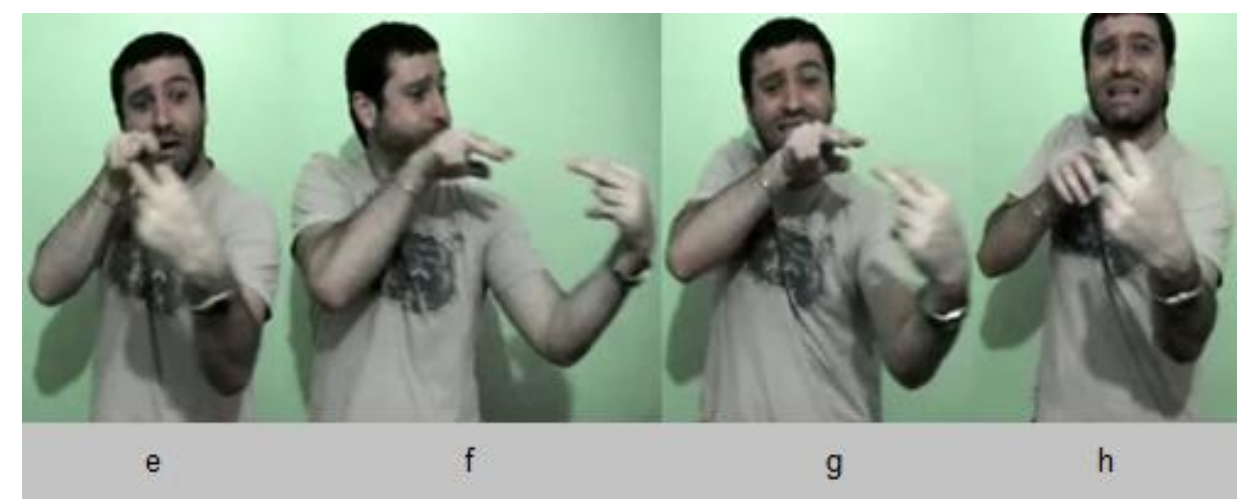

Figura 69 - Demonstração do |juiz| olhando para a |bolinha |, simultânea à demonstração manual, realizada pela fala do narrador - Trecho 42

No quadro (a), o narrador| realiza o sinal JUIZ e, no quadro (b), inicia a realização do sinal OLHAR-UM-PARA-O-OUTRO, com a mão direita posicionada próximo ao rosto e apontando para frente, e a mão esquerda um pouco à frente, apontando para o rosto. Esse verbo mapeia duas entidades: o juiz| e a |bolinha de pingue pongue| localizada à sua frente no |cenário|. Uma vez que é o juiz| e a |bolinha| que se olham, para demonstrar o movimento da |bolinha| enquanto olha para o juiz|, o |narrador| realiza o sinal UMOLHAR-PARA-O-OUTRO com a mão esquerda se movendo para a direita e para a esquerda e o apontamento da mão direita seguindo o movimento da mão esquerda. $\mathrm{O}$ movimento da mão esquerda, que mapeia a |bolinha|, é entendido, metonimicamente, como sendo o movimento da |bolinha|, enquanto olha para o |juiz| à sua frente. Nesse momento, com o olhar direcionado para baixo, entende-se que a |posição de visualização| da cena é do |juiz|, que olha para a |bolinha| se movendo diante dele, numa localização um pouco abaixo.

\section{Diálogo entre a bolinha e o juiz}

Na sequência, o |narrador| demonstra a ação corporal da |bolinha| novamente, que pede ao |juiz| que a ajude, que a pegue, como ilustra a sequência a seguir, na Figura 70. 


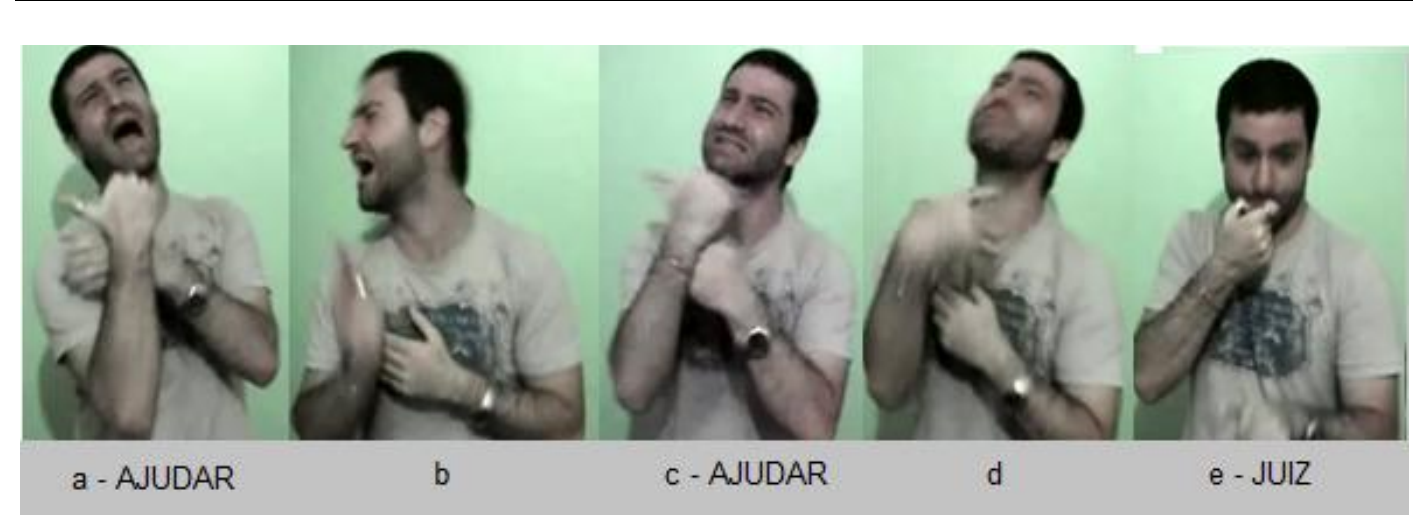

Figura 70 - Demonstração da fala da |bolinha|- Trecho 43

No quadro (a), o |narrador| demonstra a ação da |bolinha|, que, olhando para o |juiz|, à sua frente, pede, gritando, que ele a ajude: a figura mostra a expressão facial da |bolinha|, com a boca bem aberta como se estivesse gritando, e realizando o sinal AJUDAR com um movimento em direção ao corpo. Na realização desse sinal, entendese que é a |bolinha| quem fala com o juiz| e, portanto, o sinal manual é realizado no domínio da |personagem|. Nesse momento, o |narrador| produz, para representar a fala da |bolinha|, sons vocais que se assemelham à pronúncia, em português, da palavra 'ajuda' e também da palavra 'pega' (mais difícil de ser reconhecida pelos sons feitos); a pronúncia vocal desses sons é simultânea à realização do sinal AJUDAR e do gesto usado para significar 'pegar'.

No quadro (b), o |narrador|, usando a mão direita para representar a |raquete|, demostra a ação de esbofetear a |bolinha| no rosto. Em seguida, o |narrador| demonstra a ação da |bolinha|, que pede ao |juiz| que a ajude (quadro (c)) e que a pegue (quadro (d)); o gesto usado para significar 'pegar' é realizado, no quadro (d), com a mão aberta e o punho curvado, palma para dentro, fechando-se em seguida, com um movimento da mão para frente. Finalmente, o |narrador|, olhando para baixo, demonstra a ação do |juiz| (quadro (e)), que, com um aceno de cabeça afirmativo, concorda em pegar a |bolinha|. 
Ação do juiz: interrupção do jogo

A partir de então, o |narrador| demonstra a ação do |juiz|, que olha para a |bolinha| se movendo para a esquerda; estica a mão para pegá-la e segura a |bolinha| na mão, como mostra a Figura 71 a seguir.
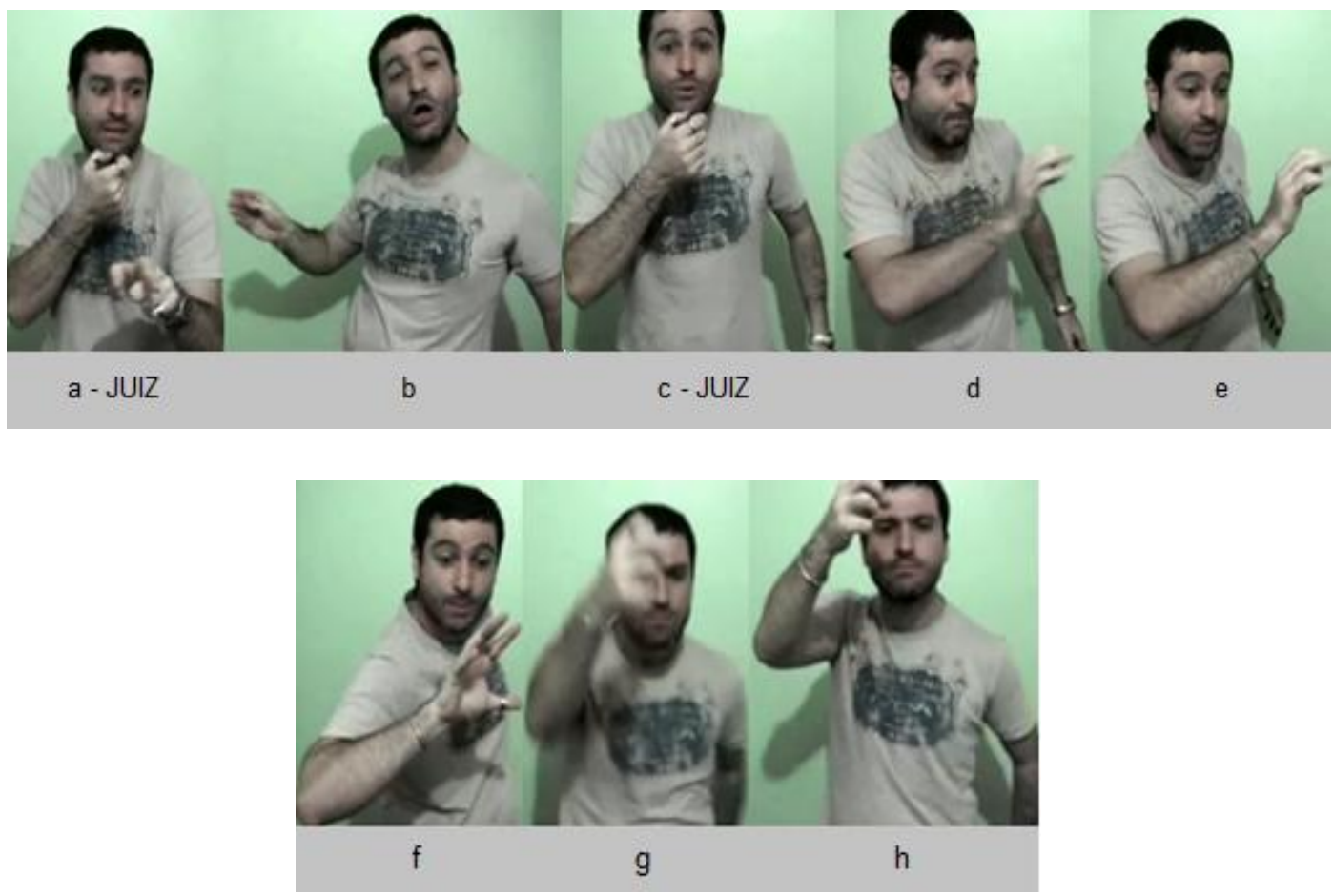

Figura 71 - Demonstração da ação do |juiz| pegando a |bolinha| em movimento Trecho 44

No quadro (a), o |narrador|, enquanto realiza o sinal JUIZ com a mão direita, ao mesmo tempo, demonstra a ação do |juiz|, que acompanha o movimento da bolinha com o olhar, na direção à esquerda. Simultameamente, o |narrador| aponta para a |bolinha| com a mão esquerda para indicar onde ela está durante o seu movimento; o apontamento manual (quadro (a)) é do |narrador|, que indica o movimento da |bolinha|, e não do juiz|. Em seguida, o |narrador|, virando o corpo para a direita, demonstra a ação do jogador delicado|, batendo na |bolinha| (quadro b). Como nas demonstrações anteriores de ações dos |jogadores|, também há, nesse momento, uma demonstração vocal do som da |bolinha| se chocando contra a |raquete|. Depois disso, no quadro (c), o |narrador| posicionando o 
corpo ao centro, olha para a câmera e realiza o sinal JUIZ. Em seguida, nos quadros (d) e (e), o |narrador| demonstra a ação do juiz| que, virando o corpo para a esquerda e direcionando o olhar para essa mesma direção, olha para a mão direita, que, nesse momento, realiza um gesto que representa a $\mid$ bolinha $\mid$ se movendo da esquerda para a direita.

Finalmente, o juiz| concorda em interromper o jogo; depois de demonstrar a ação do |jogador delicado| (quadro b), o |narrador| demonstra que o ljuiz|, vendo que a |bolinha| passa por sua frente, estica o braço, e a pega no ar.

\section{Impacto da bolinha: fim da 'câmera lenta'}

A |bolinha| para bruscamente na mão do |juiz| e, nesse momento, o |narrador| retorna à velocidade normal de realização das demonstrações, fazendo corresponder novamente a temporalidade do evento à temporalidade da narração, como é apresentado na discussão da Figura 72 a seguir.

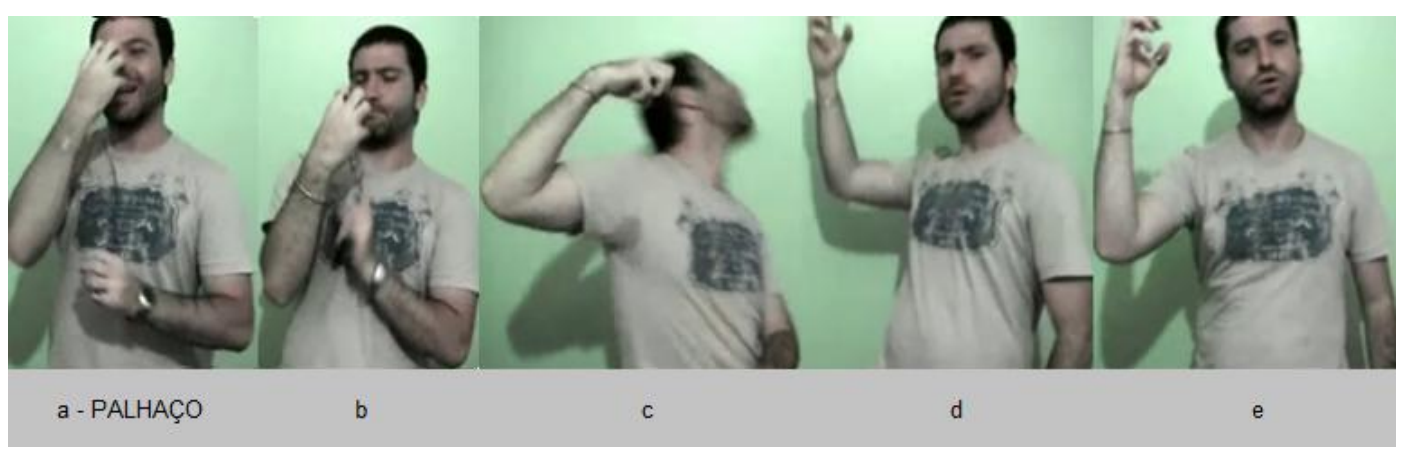

Figura 72 - Demonstração do impacto sentido pela

|bolinha| e da expresão do |juiz| Trecho 45

No quadro (a), o |narrador|, posicionando o corpo ao centro, realiza com a mão direita o sinal PALHAÇO, sorrindo. Esse sorriso é do |narrador| que, como quando apresentou a |bolinha/palhaço|, considera-a tão engraçada que o faz sorrir. Em seguida, no quadro (b), o |narrador|, assumindo uma expressão séria, desfaz o sinal PALHAÇO, mas continua com a mão configurada como na realização do sinal. Nesse momento, a mão direita representa a mão do |juiz| que segura a |bolinha|. Com a mão esquerda, 
enquanto olha para a mão direita, o |narrador| realiza um apontamento em direção à mão direita (o dedo indicador da mão direita toca a palma da mão direita). Observe-se que, enquanto a mão direita representa a mão do |juiz|, o corpo é do |narrador|: é o |narrador| quem aponta com a mão esquerda para a mão direita para fazer referência à |bolinha|. Depois disso, no quadro (c), a mão direita continua representando a mão do jjuiz|, que segura a |bolinha| e, o |narrador| demonstra, com todo o restante do corpo, o impacto da |bolinha|, agora não mais como se estivesse vendo uma filmagem em câmera lenta, mas na velocidade real da ação; contextualmente, entende-se que, como a |bolinha|, apesar do impacto, parou na mão do juiz|, esse movimento corporal brusco realizado nessa demonstração não é uma ação real da |bolinha|, mas uma demonstração do impacto sentido pela |bolinha| ao parar na mão do |juiz|, devido à velocidade em que se movimentava. Em seguida, nos quadros (d) e (e), o |narrador|, olhando para a câmera, demonstra as expressões do |juiz|: no quadro (d), vemos a sobrancelha franzida, que demonstra a tensão do juiz|; no quadro (e), o |narrador| bufa, demonstrando um alívio do esforço despendido na ação de pegar a bolinha no ar enquanto ela se movimentava.

\section{Ação do juiz}

Na sequência, o |narrador| mostra a expressão do |juiz| diante da situação, tendo que decidir o que fazer com a |bolinha|, como ilustrado pela Figura 73 a seguir.

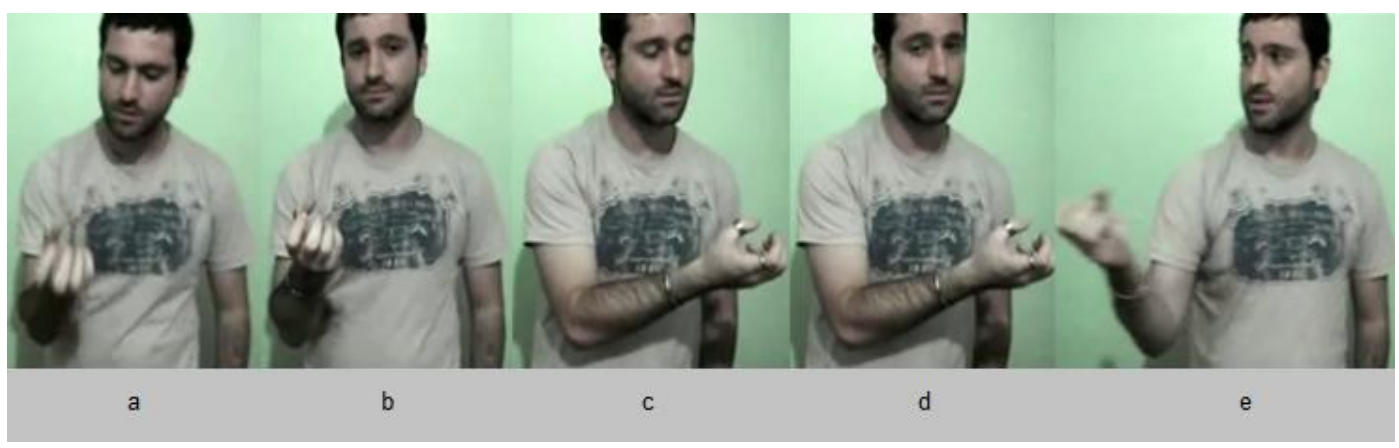

Figura 73 - Demonstração da ação do |juiz| oferecendo a |bolinha| aos |jogadores| - Trecho 46 
No quadro (a), o juiz| olha para a mão direita, que ainda representa a mão do |juiz| segurando a |bolinha| e balançando-a na mão. Em seguida, o |narrador| olha para a câmera e, depois, virando o corpo para a esquerda, demonstra a ação do |juiz| oferecendo a |bolinha| para o |jogador delicado|; no quadro (d), o |narrador| olha novamente para a câmera, enquanto sustenta a mão direita na região à esquerda por um momento e, em seguida, demonstra a ação do |juiz| levando a mão direita para a direita e direcionando o olhar para a mesma direção (quadro (e)), oferecendo a |bolinha| ao ljogador barbudo|.

\section{Encerramento}

Em seguida, demonstrando que o juiz| segura a bolinha na mão, o |narrador| olha para o |narratário| (para a câmera), como mostra a Figura 74 a seguir.

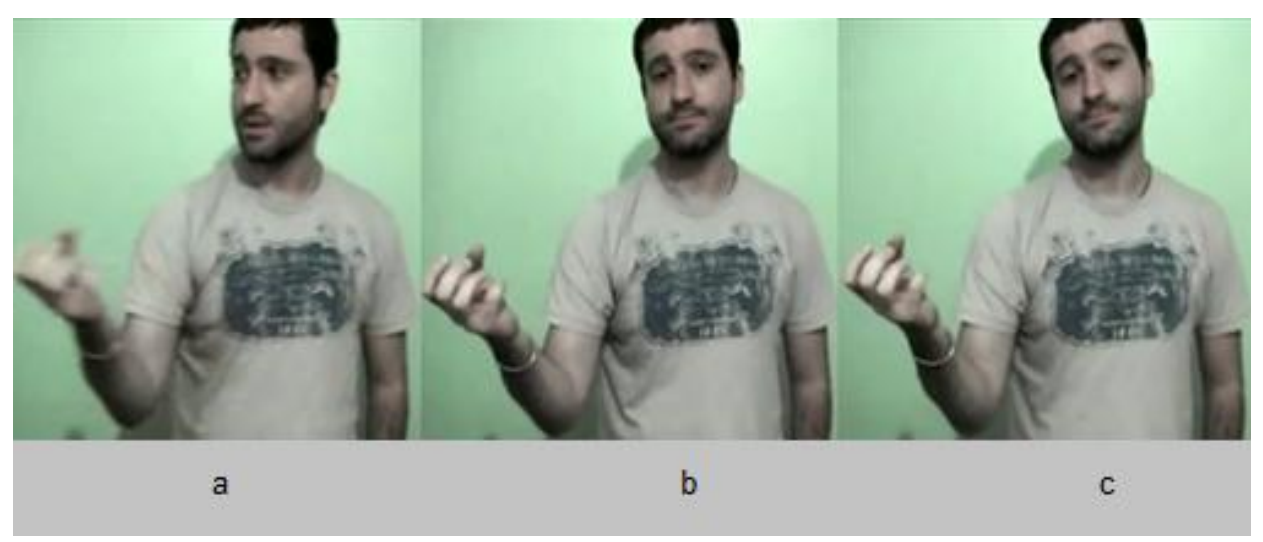

Figura 74 - Demonstração do |juiz| segurando a |bolinha | e do |narrador| acenando com a cabeça enquanto olha para a câmera - Trecho 47

No momento em que o |narrador| olha para a câmera, ainda com a mão direita representando a mão do |juiz| que segura a |bolinha|, o |narrador| faz um aceno de cabeça, inclinando a cabeça para trás, que sugere que ele faz uma pergunta ao |narratário|; nesse momento, o |narrador| parece estar pedindo uma opinião do |narratário| sobre a situação. Em seguida, o vídeo escurece e a narrativa termina. 


\subsection{CONSIDERAÇÕES FINAIS}

O objetivo deste capítulo foi apresentar uma análise da narrativa 'Bolinha de Ping Pong', observando cada uma das ocorrências de demonstração que aparecem ao longo da narrativa. Nessa análise, identificamos ocorrências de demonstrações pertencentes ao nível do sinalizador de carne-e-osso, ao nível do |narrador| e ao nível de alguma das |personagens|, bem como aqueles casos em que não é claro a que nível narrativo a demonstração pertence. Nessa identificação dos níveis a que pertencem as ocorrências, vimos que é preciso levar em consideração todas as pistas disponíveis num dado momento da narrativa, tanto aquelas elaboradas a partir dos diferentes recursos semióticos demonstração, indicação e descrição - quanto aquelas de natureza contextual, que incluem o conhecimento de mundo e um conhecimento corporeado a respeito da aparência daquilo que está sendo demonstrado.

Como o corpo do sinalizador pode ser conceitualmente partido, várias partes do corpo podem realizar demonstrações diferentes: para saber, durante a narrativa, que parte do corpo atua como narrador e que parte atua como personagem é preciso acompanhar o mapeamento conceitual dos elementos, que envolve reconhecer tanto as pistas criadas pelas descrições, isto é, pelo uso de sinais/gestos convencionais, quanto reconhecer outros elementos que participam da narração, como, por exemplo, a organização espacial dada ao cenário da história e as expressões faciais e corporais recorrentes ao longo da história.

A análise apresentada neste capítulo a respeito da narrativa 'Bolinha de Ping Pong' aponta para o fato de que contar história fluentemente em discursos sinalizados envolve ser capaz de integrar as estratégias narrativas de descrição, indicação e demonstração na organização dos elementos conceituais da narrativa e operar, empregando essas estratégias, com diferentes orientações espaciais na constituição do cenário, com as diferentes escalas dos elementos no cenário e com as diferentes posições de visualização na narração dos eventos. Apesar de essas operações serem realizadas tanto nos discursos orais quanto nos sinalizados, as análises apresentadas neste capítulo dão evidências de que as demonstrações parecem ter um peso maior nos discursos sinalizados: é por meio organização espacial, das mudanças de posições de visualização atreladas à organização do espaço e da localização de sinais em diversas posições do espaço de sinalização que a narrativa é estruturada e conceitualmente organizada. O emprego de 
demonstrações não é simplesmente uma característica imagética ou pitoresca das línguas sinalizadas, mas uma estratégia discursiva central nos discursos narrativos dessas línguas. O domínio dessa estratégia é, portanto, fundamental na constituição de uma sinalização fluente em narrativas sinalizadas. 


\section{CONCLUSÃO}

O objetivo desta dissertação foi apresentar um estudo sobre um dos aspectos das narrativas contadas presencialmente, que é o emprego de demonstrações em uma narrativa sinalizada. Para isso, parti da diferença explicitada por McCleary (2011) e McCleary \& Viotti (2014) entre narrativas escritas e narrativas presenciais, promovida pela copresença de interlocutores na contação de histórias face a face: nas narrativas contadas presencialmente, elementos como a postura corporal e expressões faciais do falante/sinalizador e de seu interlocutor não são incidentais no processo narrativo, antes têm importância fundamental na construção dos significados. Diante dessa diferença, o primeiro passo desta pesquisa foi o de buscar elementos teóricos para o entendimento de uma abordagem descritiva para narrativas sinalizadas vistas de uma perspectiva multimodal. A este tópico, dediquei o capítulo teórico desta dissertação (capítulo 2).

Para abordar a multimodalidade dos discursos presencialmente elaborados, tomei como ponto de partida as propostas de Clark (1996) e Hutchins (2010), segundo as quais, em situação de língua em uso em copresença, as pessoas precisam coordenar as suas ações para que elas sejam bem sucedidas; para Hutchins, na interação face a face, as pessoas se coordenam a partir das relações que se estabelecem entre Corpos/Falas/Mundo, levando em consideração a dimensão material e social da interação; para Clark, três estratégias cognitivas estão envolvidas no uso da língua em situações presenciais: a descrição, a demonstração e a indicação. Baseando o seu estudo na análise de língua oral, Clark mostra que as demonstrações não são tão periféricas no uso da língua, como os estudos tradicionais fazem crer: no uso da língua em situação de interação presencial, as pessoas integram sempre descrições, indicações e demonstrações na elaboração dos seus 
discursos; o emprego dessas estratégias, envolvem diferentes tipos de coordenação de ação.

No caso das demonstrações, especificamente, os falantes/sinalizadores e os seus interlocutores precisam se coordenar na imaginação conjunta da aparência das coisas e eventos demonstrados. Da perspectiva assumida neste trabalho, que leva em consideração a situação material e social da interação, a imaginação é vista como uma ação social e não simplesmente como uma habilidade cognitiva individual (Murphy, 2004). Nesse sentido, a imaginação é uma prática corporeada, envolvendo a atualização de ações conhecidas com o corpo: em certo sentido, muitas demonstrações não são outra coisa senão atuações em modo hipotético de ações aprendidas nas atividades corporeadas que realizamos conjuntamente na relação entre Corpos/Fala/Mundo, que constituem o dinamismo das situações e da vida.

Para o estudo das demonstrações em narrativa sinalizada em libras, tomei como base os trabalhos de Dudis $(2007,2011)$ e McCleary \& Viotti $(2010,2011,2014)$, todos fundamentados no trabalho seminal de Liddell (2003). As análises de Dudis a respeito de demonstrações em ASL mostram que, além do corpo e do espaço ao redor dele, outros elementos precisam ser levados em consideração: o |sujeito|, a |posição de visualização| e a |temporalidade|. Para tratar desses elementos num tipo de discurso específico, que é a narrativa, foi preciso levar em consideração os níveis de intersubjetividade que se estabelecem no discurso narrativo: autor/interlocutor implicito, narrador/narratário, personagem(s)/personagem(s). Como mostram McCleary \& Viotti (2010, 2011, 2014), nas narrativas sinalizadas, os níveis de intersubjetividade narrativos são corporeados, de modo que a passagem de um nível a outro é expresso por marcas corporais, como mudança na postura, na expressão facial e no direcionamento do olhar. Com base na proposta desses autores, o objetivo das análises foi a de identificar ocorrências de demonstração nos diferentes níveis de intersubjetividade e analisar essas ocorrências.

A observação e análise das ocorrências de demonstração nos discursos é grandemente favorecida pela facilidade que hoje se tem de filmar os discursos e observálos em detalhes, usando as ferramentas que hoje dispomos para abordagem de materiais audiovisuais nas análises de discurso multimodal. Nesse sentido, depois de ter discutido uma abordagem descritiva para o estudo de narrativas vistas de uma perspectiva multimodal, passei a discutir e apresentar aspectos metodológicos dessa abordagem 
(capítulo 3). Nessa discussão, apresentei a fonte de onde obtive os dados, o modelo de transcrição usado na pesquisa e algumas vantagens da utilização do software ELAN para operação com o material audiovisual.

Com base na proposta de Dudis para o estudo de demonstrações em discursos da ASL e na proposta de McCleary \& Viotti para o estudo de narrativas em libras, fiz uma análise das ocorrências de demonstração na narrativa "Bolinha de Ping Pong" (capítulo 4). Considerando que o mesmo corpo que está presente na interação material é aquele usado para instanciar as figuras do |narrador| e das |personagens|, uma pergunta que se coloca nas análises é a que nível de intersubjetividade uma determinada ocorrência de demonstração pertence: se ao nível do sinalizador de carne-e-osso, do |narrador| ou ao de alguma |personagem|. Nesta análise, busquei, então, identificar não só as ocorrências de demonstração como também as pistas disponíveis para identificar a que nível uma determinada ocorrência de demonstração pertence. Na narrativa "Bolinha de Ping Pong", identifiquei ocorrências de demonstração em todos os níveis de intersubjetividade: no nível do sinalizador de carne-e-osso, no nível do |narrador| e no nível das várias |personagens|.

Este trabalho contribui para reforçar algumas observações que têm sido feitas no campo da linguística em geral, e na área da linguística das línguas de sinais, em particular. A primeira delas refere-se à importância da análise de dados de língua em uso, em especial em interações face a face. Demonstrações contribuem de maneira substancial para a construção da significação dos discursos presenciais, tanto orais quanto sinalizados. Quando a linguística se volta quase que inteiramente para o estudo de discursos escritos, ou quando se pauta pelo exame de dados descontextualizados obtidos por meio da intuição de falantes nativos, ela deixa de acessar essa fonte de significação construída pela ação conjunta de corpos em copresença. No caso específico dos discursos sinalizados, isso assume uma dimensão ainda maior. Como a análise da narrativa 'Bolinha de Ping Pong' evidencia, demonstrações constituem grande parte da contação da história. É quase que inteiramente por meio delas que (i) distinguem-se os níveis de intersubjetividade narrativa; (ii) introduzem-se e caracterizam-se as personagens; (iii) faz-se a retomada das personagens; (iii) narram-se os eventos da história. Portanto, abrir mão da análise de demonstrações no estudo das línguas de sinais significa excluir do 
estudo aquilo que parece ser um dos maiores recursos da gramática e da organização do discurso dessas línguas.

Mais análises sobre demonstrações precisam ser feitas, para que fiquem mais e mais claros alguns dos aspectos essenciais do discurso sinalizado, como a organização espacial, a posição de visualização, a temporalidade, a localização de sinais em diferentes pontos do espaço de sinalização. É certo que a literatura em que este trabalho se baseia já vem apontando para a relevância dessas características há algum tempo. Talvez o que deva ser feito a seguir é investigar o impacto que possíveis alterações na organização espacial e mudanças de posição de visualização, de escala e de temporalidade venham a ter na significação dos discursos. 


\section{Referências}

BARBOSA, T. B. (2013). Uma descrição do processo de referenciação em narrativas contadas em língua de sinais brasileira (libras). São Paulo, SP: Universidade de São Paulo.

BAVELAS, J., \& CHOVIL, N. (1997). Faces in dialogue. In: The psychology of facial expression (pp. 334-346). Cambridge, UK: Cambrigde University Press.

BOLGUERONI, T., \& VIOTTI, E. (2013). Referência nominal em língua de sinais brasileira (libras). Todas as Letras, v. 15, n.1, 15-50.

BRANDT, L., \& BRANDT, P. (2005). Making sense of a blend: A cognitive-semiotic approach to metaphor. Annual Review of Cognitive Linguistics, (pp. 216-249).

CAPOVILlA, F. C.; RAPHAEL, W. D. (2002). Dicionário Enciclopédico Ilustrado

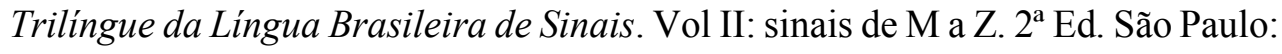
Editora da Universidade de São Paulo: Imprensa Oficial do Estado.

CHAFE, W. (1994). Discourse, consciousness and time. Chicago: University of Chicago Press.

CLARK, H. (1996). Using Language. Cambridge University Press.

CLARK, H., \& GERRIG, R. (1990). Quotations as demonstrations. Language, 66, 764805.

COGILL, D. (1999). Classifier predicates: Linguistic structures or templated visual analogy? University of New England: Manuscrito não publicado.

DUDIS, P. (2004). Body partitioning and real-space blends. Cognitive Linguistics 15-2, 223-238.

DUDIS, P. (2007). Types of Depiction in ASL. Washighton, DC: Gallauted University Press.

DUDIS, P. (2011). The body in scene depiction. In: C. B. Roy (ed.) Discourse in Signed Language (pp. 3-45) Washighton, DC: Gallauted University Press.

ENGBERG-PEDERSEN, E. (1993). Space in Danish Sign Language: the Semantics and Morphosyntax of the Use of Space in a Visual Language. Hamburg: Signum Press.

FAUCONNIER, G. (1994). Mental Spaces. New York: Cambridge University Press. 
FAUCONNIER, G. (1997). Mappings in Thought and Language. Cambridge: Cambridge University Press.

FAUCONNIER, G., \& TURNER, M. (2002). The Way We Think. New York: Basic Books.

HUTCHINS, E. (2010). Imagining the cognitive life of things. In: Malafouris L., \& Renfrew. C., The cognitive life of things: recasting the boundaries of the mind. Cambridge UK: McDonald Institute Monographs.

HUTCHINS, E. \& PALEN. L. (1997). Constructing meaning from spaces, gesture, and speech. In: Resnick, C. Pontecorvo, R., Saljo. Discourse, Tools e Reasoning: Essays on Situated Cognition (pp. 23-40). Berlin: Springer.

KENDON, A. (1988). Sign languages of Aboriginal Australia: Cultural, semiotic, and communicative perspectives. Cambrigde: Cambridge University Press.

KOUSHA, K., THELWALL, \& ABDOLI, M. (2012). The role of online videos in research communication: A content analysis of YouTube videos cited in academic publications. Journal of the American Society for Information Science and Technology, 63(9), pp. 1710-1727.

LABOV, W., \& WALEZKY, J. (1967). Narrative analysis: Oral versions of personal experience. . In: Helm, J. (ed.). Essays on the verbal and visual arts. (pp. 12-44). Seattle, WA: University of Washington Press.

LANGACKER, R. (2008). Cognitive Grammar: a basic introduction. New York: Oxford University.

LEITE, T. A. (2008). A segmentação na língua de sinais brasileira libras: um estudo linguístico descritivo a partir da conversação espontânea entre surdos. Tese de doutorado. Departamento de Letras Modernas, USP.

LIDDELL, S. (2003). Grammar, Gesture and Meaning in American Sign Language. Cambrigde University Press.

LEITE, T. de A.; MCCLEARY, L. (2013). The identification of grammatical units in Brazilian Sign Language: a usage-based approach. Todas as Letras, São Paulo, v. 15, n.1, p. $62-87$.

MCCLEARY, L. E. (2011). História oral: Questões de língua e tecnologia. In: Ricardo Santhiago e Valéria Barbosa Magalhães. (org.), Memória e Diálogo: escutas da Zona Leste. Visões sobre a história oral. (pp. 93 - 123). São Paulo: Letra e Voz, Fapesp. 
MCCLEARY, L. (2013). Manuscrito (handout) apresentado no curso 'Multimodalidade na interação face a face', sugerindo mudanças no sistema de transcrição do modelo apresentado por McCleary, Viotti \& Leite (2010).

MCCLEARY, L., \& VIOTTI, E. (2010). Sign-Gesture Symbiosis in Brazilian Sign Language Narrative. In: Meaning, Form, and Body (pp. 181-201 ). University of Chicago Press.

MCCLEARY, L. \& VIOTTI, E. (2011). Língua e gesto em línguas sinalizadas. Revista de Estudos linguísticos Veredas. Atemática.

MCCLEARY, L., \& VIOTTI, E. (2014). Espaços integrados e corpos partidos: vozes e perspectivas. Scripta, 18 (34), a sair.

MCCLEARY, L., VIOTTI, E., \& LEITE, T. (2010). Descrição de línguas sinalizadas: a questão da transcrição dos dados. Revista Alfa, v. 54, n.1.

MCNEILL, D. (1992). Hand and Mind: What gestures reveal about thought. Chicago e London: University of Chicago Press.

METZGER, M. (1995). Constructed dialogue and constructed action in American Sign Language. In: Sociolinguistics in Deaf Communities. Ceil Lucas. (ed.). Washington, DC:: Gallaudet University Press, pp. 255-271.

MOREIRA, R. L. (2007). Uma descrição da dêixis de pessoa na língua de sinais brasileira: pronomes pessoais e verbos indicadores. Dissertação de mestrado. Departamento de Linguística, USP.

MURPHY, K. (2004). Imagination as joint activity: The case of architectural interaction. Mind, Culture and Activity, 11(4), 267-278.

OAKLEY, T. V. (2009). From attention to meaning. Explorations in semiotics, linguistics, and rhetoric. New York, Oxford, Brussels: Peter Lang.

POYATOS, F. (2002). Language, paralanguage, kinesics: The basic triple structure of human communication. In: NonVerbal communication across disciplines: Culture, sensory interaction, speech, conversation (pp. 103-32). Philadelphia: John Benjamins.

SCHEMBRI, A. (1996). The structure and formation of signs in Auslan (Australian Sign Language). Sydney: North Rocks Press.

SCHEMBRI, A. (2003). Rethinking "classifiers" in signed languages. In: Emmorey, K. Perspectives on classifier constructions in sign languages (pp. 3-34).

SINGLETON, J. L., MORFORD, J. P. \& GOLDIN-MEADOW, S. (1993). Once is not enough: Standards of well-formedness in manual communication created over three different timespans. Language, 69 (4) pp. 683-715. 
SUPALLA, T. (1986). The classifier system in American Sign Language. In: C. G. Craig, (ed.), Noun Classes and Categorization. Proceedings of a symposium on categorization and noun classification (p. 481). Amsterdam/Philadelphia: John Benjamin Publishing Company.

TURNER, M. (1996). The Literary Mind: The Origins of Thought and Language. New York: Oxford. 